Rolando Enrique Zea Huallanca

\title{
MECANISMOS DE RUPTURA EM TALUDES ALTOS DE MINERAÇÃO A CÉU ABERTO
}

Dissertação apresentada à Escola de Engenharia de São Carlos, da Universidade de São Paulo, como parte dos requisitos para a obtenção do Título de Mestre em Geotecnia.

Área de Concentração: Mecânica das Rochas ORIENTADOR: Prof. Dr. Tarcísio Barreto Celestino 
Ficha catalográfica preparada pela Seção de Tratamento da Informação do Serviço de Biblioteca - EESC/USP

Zea Huallanca, Rolando Enrique

Mecanismos de ruptura em taludes altos de mineração a céu aberto / Rolando Enrique Zea Huallanca. -- São

Carlos, 2004.

Dissertação (Mestrado) -- Escola de Engenharia de São Carlos - Universidade de São Paulo, 2004.

Área: Geotecnia.

Orientador: Prof. Dr. Tarcísio Barreto Celestino.

1. Mecanismos de ruptura. 2. Tensões induzidas. 3. Dano induzido. 4. Ruptura progressiva. 5. Mineração a céu aberto. 6. Análise numérica. I. Título. 
FOLHA DE JULGAMENTO

Candidato: Engenheiro ROLANDO ENRIQUE ZEA HUALLANCA

Dissertação defendida e julgada em 14-12-2004 perante a Comissão Julgadora:

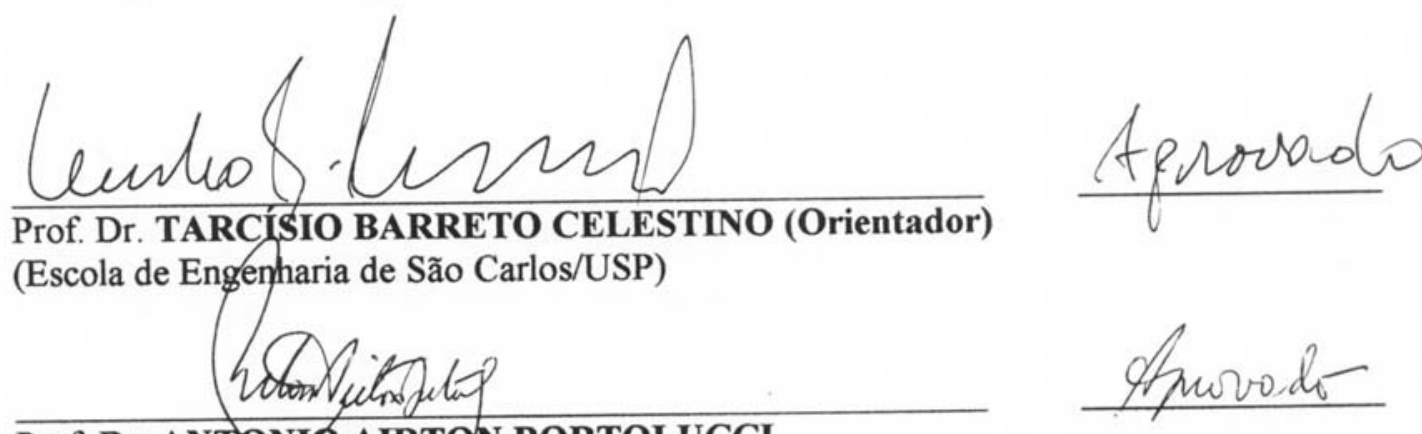

Prof. Dr. ANTQNIO AIRTON BORTOLUCCI

(Escola de Engenharia de São Carlos/USP)

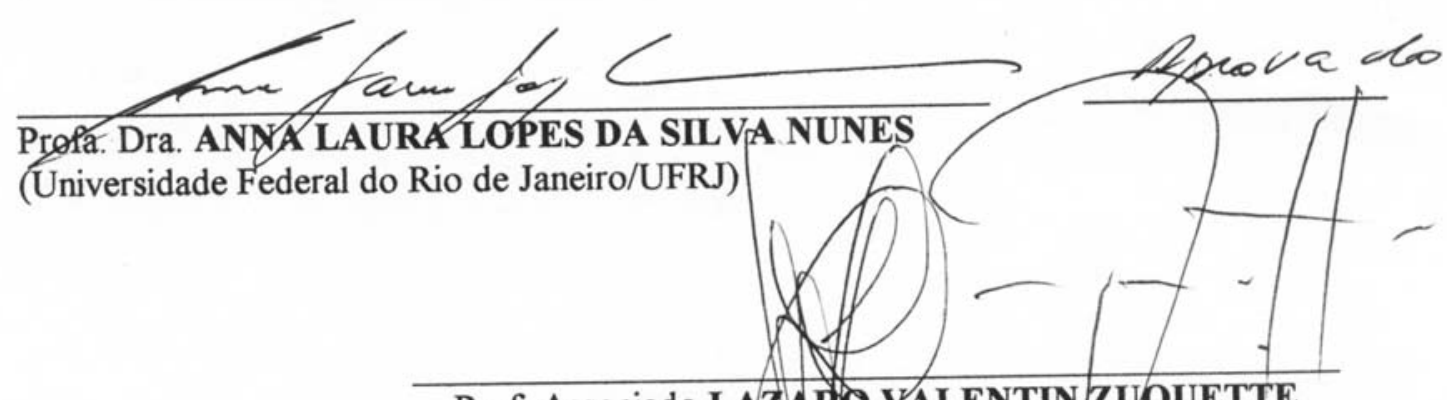

Prof. Associado LAZA RO YALENTIN ZUQUETTE

Coordenador do Programa de Pós-Graduação em Geotecnia

Marfan incado

Profa. Titular MARIA DO CARMO CAđIJURI
Presidente da Comissão de Pós-Graduação da EESC 
"Aos meus Pais, Julia e Enrique, com amor e gratidão inefáveis" 


\section{AGRADECIMENTOS}

Expresso a minha gratidão sincera ao Prof. Dr. Tarcísio Barreto Celestino, meu orientador, visto que os ensinamentos e as orientaçoes dele recebidos desde o inicio do meu estudo e da minha pesquisa no mestrado na Escola de Engenharia de São Carlos USP foram essenciais para a conclusão desta dissertação. Gostaria também de agradecer ao Prof. Dr. Sergio Persival Baroncini Proença pela amizade e valiosa contribuição ao desenvolvimento da minha pesquisa, ao Prof. Dr. Nelson Aoki pelas suas sugestões que orientaram a plena execução do trabalho, ao Prof. Dr. Edmundo Rogério Esquivel e ao Prof. Dr. Antonio Airton Bortolucci pelo fornecimento de alguns materiais que foram de muita ajuda e ao Prof. Pablo Meza Arestegui da Universidad Nacional de San Agustín de Arequipa - Peru, pelos primeiros ensinamentos da mecânica das rochas e por ter contribuído na minha formação em Geotecnia e ter me incentivado a iniciar o curso de Mestrado.

Adicionalmente, gostaria de agradecer aos funcionários do Departamento de Geotecnia pelo apoio técnico e pela boa convivência, aos professores do Departamento de Geotecnia que sempre contribuíram no meu aperfeiçoamento profissional e pessoal, aos amigos e colegas do departamento de Geotecnia, que contribuíram, de uma ou outra maneira, seja com palavras, gestos, atitudes e até mesmo com o silêncio, ao colega Eng. Heraldo Pitanga pela disponibilidade incondicional do seu tempo em ler e corrigir o português de uma grande parte do texto e às colegas Karla Wingler e Regiane Veloso que também contribuíram com algumas correções.

Em especial, agradeço aos meus pais, Enrique e Julia, pelo amor e incentivo que nunca diminuíram, mesmo com o tempo e a distância, à minha querida irmã Janeth pelo apoio a toda hora.

Agradeço à CAPES pelo apoio financeiro prestado para a concretização deste trabalho. 


\section{RESUMO}

ZEA, R.E. (2004). Mecanismos de ruptura em taludes altos de mineração a céu aberto. Dissertação de Mestrado - Escola de Engenharia de São Carlos, Universidade de São Paulo, São Carlos, 2004. 124p.

$\mathrm{Na}$ última década, muitas minas a céu aberto têm alcançado alturas de 600 metros ou mais, algumas com perspectiva em projeto de alcançar mais de $1100 \mathrm{~m}$. A literatura especializada revela que os mecanismos de ruptura para taludes altos ainda não são bem entendidos. Existem dúvidas tanto em relação aos mecanismos de ruptura, como quanto à estimativa da resistência do maciço rochoso em tal escala. Recentemente, há uma tendência crescente da aplicação de análises numéricas para estudar a estabilidade de taludes altos, mas ainda não se consegue reproduzir todos os fenômenos envolvidos. Análises reportadas na literatura consideram apenas a configuração final da cava, sem levar em conta o processo evolutivo da escavação, e o dano induzido ao maciço decorrente deste processo. Este trabalho analisa este efeito e suas conseqüências na avaliação da segurança.

Realizaram-se análises bidimensionais de tensão-deformação em taludes de rocha. Tais análises foram realizadas com modelos elástico linear e elasto-plástico de amolecimento da coesão e de endurecimento do atrito, considerando a mobilização não simultânea das componentes de resistência no critério de Mohr-Coulomb, e a danificação do maciço rochoso. Avaliação preliminar da segurança de um talude hipotético mostrou que estas considerações são muito importantes. Foram considerados a altura do talude, o ângulo do talude e as tensões in situ.

O histórico de tensões modifica os parâmetros de resistência do maciço ao longo do talude por danificação. A região do pé do talude, em cada estágio de escavação, está sujeita a concentração de tensões induzidas que geram danificação do maciço nestas áreas. A danificação em regiões do pé do talude pode explicar o início do processo de ruptura do tipo progressivo.

Palavras-chave: mecanismos de ruptura, tensões induzidas, dano induzido, ruptura progressiva, mineração a céu aberto, análises numéricas. 


\begin{abstract}
ZEA, R.E. (2004). Failure mechanisms in high rock slopes at open pit mining. M.Sc. Dissertation - São Carlos Engineering School, University of São Paulo. São Carlos, 2004. $124 p$.
\end{abstract}

Along the last decade, many open pit mines have reached up to 600 meters or more in height, and some of them are planned to reach more than 1100 meters. The specialized literature shows that the failure mechanisms for high rock slopes are not well understood as yet. Doubts exist in relation to failure mechanisms, as well as to rock mass strength estimation in such scale. In recent years, there is a growing trend for the use of numerical analyses in order to study high rock slope stability, but they are not capable to reproduce all the phenomena involved.

Analyses reported in the literature consider only the final configuration of the open pit, without taking into consideration the excavation evolution process, and damage induced to the rock mass resulting from this process. This work analyzes this effect and its consequences on the slope safety evaluation. Two-dimensional stress-strain analyses in rock slopes are described. Such analyses were conducted with linear elastic model and elasto-plastic Strain Cohesion Softening - Friction Hardening model considering the nonsimultaneous mobilization of the strength components in the Mohr-coulomb criterion, by including the rock mass damage. An approximate safety evaluation of a hypothetical slope shows that these considerations are very important.

The stress path modifies the rock mass strength parameters close to the slope face by damage. The regions of the slope toe at each excavation stage are subjected to induced stress concentration causing damage to rock. This damage can explain the beginning of the progressive failure mechanism.

Key words: failure mechanisms, induced stresses, induced damage, progressive failure, open pit mining, numerical analysis. 
FIGURA 1.1 Configuração dos taludes numa mina a céu aberto 2

FIGURA 1.2 Provável superfície de ruptura em taludes altos, envolvendo vários

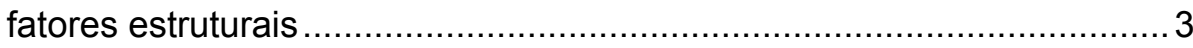

FIGURA 2.1 Fatores que influenciam o comportamento do maciço rochoso................. 6

FIGURA 2.2 Redistribuição das tensões com a mudança de geometria .......................9

FIGURA 2.3 Exemplo da estrutura do maciço rochoso............................................11

FIGURA 2.4 Tipos de descontinuidades conforme a sua persistência .......................13

FIGURA 2.5 Tipos de rupturas em taludes de mineração a céu aberto (Mod. de PATTON e DEERE, 1971)

FIGURA 2.6 Modos de ruptura mais freqüentes em taludes altos (Mod. de SJÖBERG, 1999)

FIGURA 2.7 Exemplo de ruptura em taludes altos de mineração a céu aberto (HOEK et al., 2000b)

FIGURA 2.8 Rupturas com controle estrutural: (a) ruptura planar e (b) ruptura

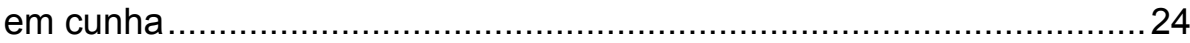

FIGURA 2.9 Ruptura por tombamento de grandes dimensões (CALL et al. 2000).....27

FIGURA 2.10 Mecanismos de rupturas: ruptura circular (SJÖBERG, 1999) …............28

FIGURA 2.11 Mecanismos de ruptura: ruptura por tombamento (SJÖBERG, 1999)

FIGURA 2.12 Instrumentação Geotécnica para o monitoramento de taludes altos em mineração a céu aberto

FIGURA 2.13 Fase de ruptura progressiva e ruptura regressiva (BROADBENT e ZAVODNI, 1982)

FIGURA 3.1 Comparação do crescimento das micro-fissuras versus a orientação das mesmas: (a) Amostra não carregada. (b) amostra carregada uniformemente até uma tensão próxima da tensão de pico (Mod. de HOLZHAUSEN e JOHNSON, 1979)

FIGURA 3.2 Curva característica tensão-deformação axial: início de microfissuras $\left(\sigma_{c i}\right)$, dano por micro-fissuras $\left(\sigma_{c d}\right)$; resistência de pico $\left(\sigma_{f}\right)$ (MARTIN, 1993) 37

FIGURA 3.3 Granito Lac du Bonnet: (a) resistência de amostras não confinadas submetidas a carga constante de longo prazo (MARTIN e CHANDLER, 1994). (b) relação entre a resistência de longo prazo, 
normalizada pela resistência de pico, em função da tensão confinante $\sigma_{3}$ (Mod. de MARTIN, 1997)

FIGURA 3.4 Perda da resistência coesiva e mobilização da resistência ao atrito em função da deformação axial (MARTIN e CHANDLER, 1994) 41

FIGURA 3.5 Ângulo de atrito total e resistência coesiva normalizada em relação à resistência de pico versus o dano normalizado em relação ao dano máximo (MARTIN e CHANDLER, 1994)

FIGURA 3.6 Mobilização das componentes da resistência no modelo CWFS em ensaios de compressão (HAJIABDOLMAJID, 2001).

FIGURA 3.7 Dano induzido por mecanismos de tração, levando à mobilização não simultânea das componentes da resistência (HAJIABDOLMAJID e KAISER, 2002)

FIGURA 3.8 Variação do módulo de elasticidade e coeficiente de Poisson em função do dano (MARTIN e CHANDLER, 1994)

FIGURA 3.9 Variação do Módulo de elasticidade em função dos ciclos de carregamento para a argamassa e o calcário Irati (NÓBREGA, 1994)

FIGURA 4.1 Comportamento plástico de um material metálico: (a) real (b) idealizado (Apud. PROENÇA, 1988)

FIGURA 4.2 (a) Diagrama esquemático tensão-deformação para rochas duras

(b) caracterização do comportamento do geomaterial por modelos constitutivos (Apud. HAJIABDOLMAJID, 2000)..................................50

FIGURA 4.3 Critério de ruptura de Mohr-Coulomb .................................................54

FIGURA 4.4 Funções de plastificação e função de potencial plástico para o modelo elasto-plástico perfeito de Mohr-Coulomb .................................56

FIGURA 4.5 Leis de fluxo associada e não associada ...........................................57

FIGURA 4.6 Funções empíricas para: (a) Endurecimento do atrito e (b) Amolecimento da coesão (VERMEER e DE BORST, 1984) 60

FIGURA 4.7 Aproximação exponencial para o amolecimento da resistência coesiva, (a) EQUAÇÃO 4.23, (b) EQUAÇÃO 4.26.

FIGURA 4.8 Aproximação para o endurecimento do atrito, EQUAÇÃO 4.18: (a) $\phi_{o}=0,(\mathrm{~b}) \phi_{o}=10$

FIGURA 4.9 (a) Deslizamentos em micro-fissuras (VERMEER e DE BORST, 1984), e (b) deslizamentos entre grupos de partículas (WODD, 1990), ambos originam dilatância

FIGURA 4.10 Ensaio de cisalhamento direto da areia Ottawa: (a) atrito mobilizado no plano horizontal $(q / p)$ versus deslocamento 
horizontal $\left(u_{x}\right) ; \quad$ (b) deslocamento vertical $\left(u_{y}\right)$ versus deslocamento horizontal (WOOD, 1990).

FIGURA 4.11 Modelo adimensional do comportamento de cisalhamento de juntas (Apud. BARTON et al., 1985)

FIGURA 4.12 Evolução do ângulo de atrito total versus o dano normalizado em relação ao dano máximo para uma amostra submetida a carregamentos cíclicos (MARTIN e CHANDLER, 1994)

FIGURA 4.13 Evolução do atrito total durante o processo de ruptura: mobilização e degradação

FIGURA 4.14 Exemplo mostrando a variação da forma da curva de degradação em função da constante $\kappa$

FIGURA 4.15 Amolecimento da coesão no Granito Lac du Bonnet em função da deformação plástica efetiva, $\bar{\varepsilon}^{p}$, ajustada à EQUAÇÃO 4.26

FIGURA 4.16 Comportamento de mobilização e de degradação do atrito total $\left(\phi_{b}+\phi_{i}\right)$ para o Granito Lac du Bonnet em função da deformação plástica efetiva, $\bar{\varepsilon}^{p}$, ajustado às EQUAÇÕES 4.36 e 4.37 72

FIGURA 4.17 Comparação de resultados obtidos entre os resultados experimentais e os obtidos pelo modelo de Amolecimento da coesão e de Endurecimento do atrito por deformação plástica para o Granito Lac du Bonnet.

FIGURA 4.18 Simulação numérica do comportamento do Granito Lac du Bonnet, considerando a ruptura progressiva através do modelo de Amolecimento da coesão e de Endurecimento do atrito por deformação plástica

FIGURA 4.19 Evolução da coesão e do atrito total para os pontos de monitoramento 1 e 2, conforme o modelo de Amolecimento da coesão e de Endurecimento do atrito por deformação plástica

FIGURA 4.20 Evolução da coesão normalizada versus ângulo de atrito total durante o processo de ruptura (ensaios cíclicos) para o Granito Lac du Bonnet

FIGURA 4.21 Comparação entre a rocha intacta e o maciço rochoso...........................79

FIGURA 4.22 Coesão versus ângulo de atrito total: passo da rocha intacta ao maciço rochoso

FIGURA 5.1 Condições de contorno e estado de tensões iniciais para modelos de taludes empregados nas análises numéricas com o programa FLAC $^{2 D}$ 
FIGURA 5.2 Envoltória de ruptura de Hoek-Brown e Mohr-Coulomb para o maciço rochoso "rocha Diorito", Mina Toquepala, Peru.

FIGURA 5.3 Evolução das tensões principais em decorrência do avanço da escavação, para pontos localizados próximo do pé do talude, nos diferentes estágios de escavação, num talude final de $300 \mathrm{~m}$ de altura, $40^{\circ}$ de inclinação, e $k=1,1$

FIGURA 5.4 Rotação das tensões principais em decorrência do avanço da escavação, para pontos localizados próximo do pé do talude, nos diferentes estágios de escavação, num talude final de $300 \mathrm{~m}$ de altura, $40^{\circ}$ de inclinação, e $k=1,1$

FIGURA 5.5 Trajetória das tensões decorrentes do avanço da escavação para pontos localizados no pé do talude nos diferentes estágios de escavação, num talude de 300 metros de altura e ângulo de talude de $40^{\circ}$ e $k=1,1$

FIGURA 5.6 Trajetória das tensões decorrentes do avanço da escavação para pontos localizados ao longo de uma provável superfície de ruptura nos diferentes estágios de escavação, num talude de 300 metros de altura e ângulo de talude de $40^{\circ}$ e $k=1,1$

FIGURA 5.7 Tensão principal maior induzida versus o coeficiente de empuxo para pontos localizados na região do pé do talude, ângulo de talude $40^{\circ}$.

FIGURA 5.8 Tensão principal menor induzida versus o coeficiente de empuxo para pontos localizados na região do pé do talude, ângulo de talude $40^{\circ}$

FIGURA 5.9 Estado de tensões induzido na região do pé do talude, para diferentes alturas de taludes e coeficientes de empuxo, ângulo de talude $40^{\circ}$

FIGURA 5.10 Orientação da tensão principal maior induzida versus o coeficiente de empuxo, para a região do pé do talude

FIGURA 5.11 Orientação da tensão principal maior induzida para a região do pé do talude versus a altura do talude

FIGURA 5.12 Esquema teórico-idealizado do desenvolvimento de fraturas em regiões de acúmulo de tensões (pé do talude) decorrentes do avanço da escavação

FIGURA 5.13 (a) Amolecimento da coesão, (b) comportamento de mobilização e de degradação do atrito total adotados para a rocha Diorito

FIGURA 5.14 Perda da resistência coesiva em decorrência do dano devido ao avanço da escavação num talude de 300 metros de altura 
FIGURA 5.15 Mobilização do atrito em decorrência do dano devido ao avanço da escavação num talude de 300 metros de altura

FIGURA 5.16 Plotagem da perda da resistência coesiva (dano) e os respectivos parâmetros geométricos adotados para definir o dano no talude..... 103

FIGURA 5.17 Variação do parâmetro $H_{D}, D_{H}$ e $D_{V}$ em função da altura do talude 104

FIGURA 5.18 Variação do parâmetro $H_{D} / H, D_{H} / H$ e $D_{V} / H$ em função da altura do talude. 106

FIGURA 5.19 - Análise 1: procedimento convencional sem consideração do dano ..... 108

FIGURA 5.20 - Análise 2: procedimento com consideração de dano, modelo simplificado 
TABELA 4.1 Propriedades do Granito Lac du Bonnet usadas no modelo

.73

TABELA 5.1 Parâmetros de entrada a serem usados na simulação numérica bidimensional tensão-deformação 84

TABELA 5.2 Estimativa do fator de segurança por análise convencional e por análise com dano 


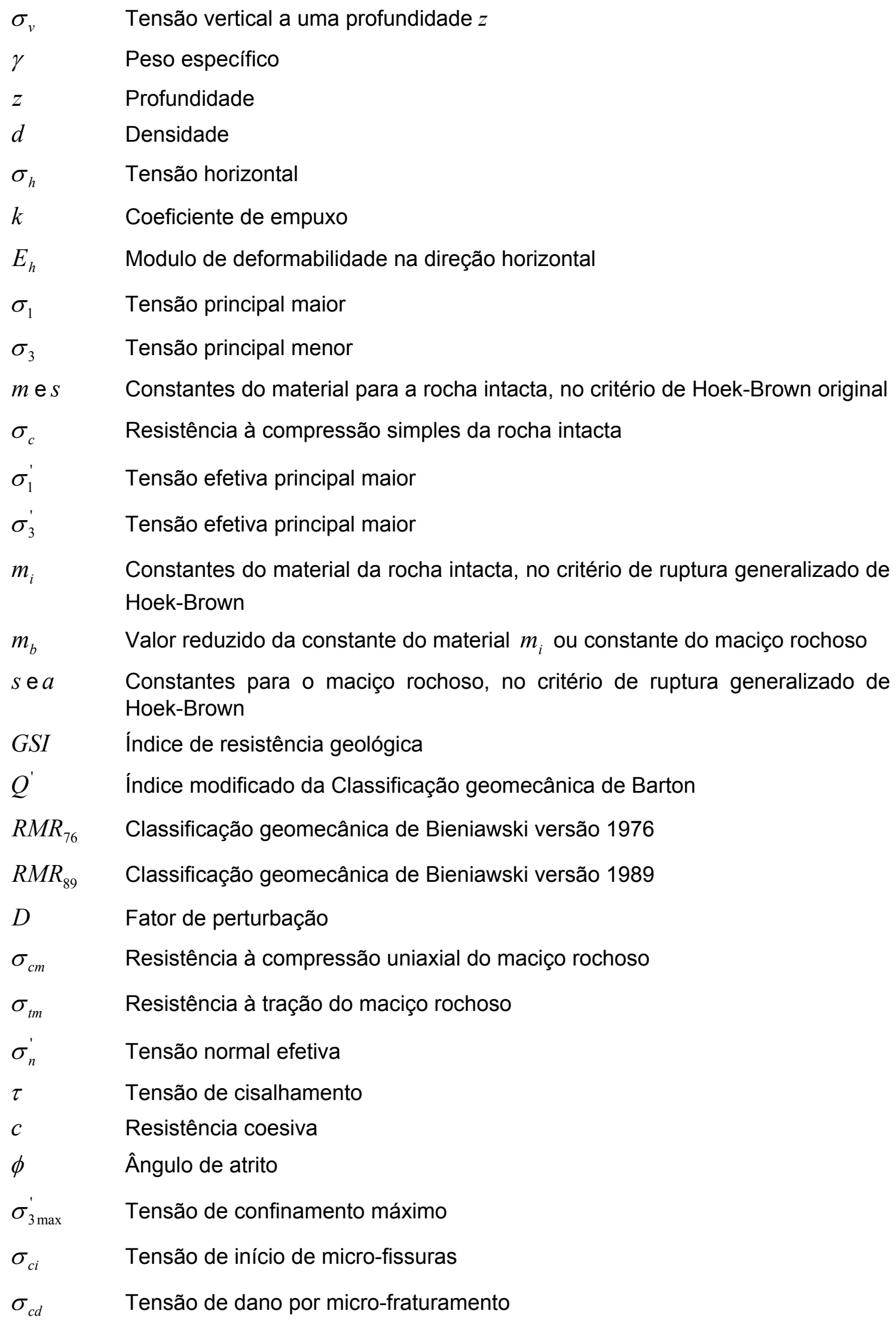




\begin{tabular}{|c|c|}
\hline$\sigma_{f}$ & Tensão de pico \\
\hline$\sigma_{d i}$ & Tensão de inicio do dano \\
\hline$E$ & Módulo de elasticidade \\
\hline$v$ & Coeficiente de Poisson \\
\hline$\phi_{b+i}$ & Ângulo de atrito total \\
\hline$\phi_{b}$ & Ângulo de atrito básico \\
\hline$\phi_{i}$ & Componente devido ao intertravamento e de rugosidade \\
\hline$\omega$ & Dano \\
\hline$\varepsilon$ & Deformação total \\
\hline$\varepsilon^{e}$ & Deformação elástica \\
\hline$\varepsilon^{p}$ & Deformação plástica \\
\hline$f$ & Função de plastificação \\
\hline$\sigma_{i j}$ & Tensor de tensões simétrico \\
\hline$\varepsilon_{i j}^{p}$ & Componentes do tensor de deformações plásticas \\
\hline$g$ & Função do potencial plástico \\
\hline$\lambda$ & Fator escalar positivo de proporcionalidade \\
\hline$\varepsilon_{v}^{p}$ & Deformação volumétrica plástica \\
\hline $\bar{\varepsilon}^{p}$ & Deformação plástica efetiva \\
\hline$d \varepsilon_{1}^{p}$ & Incremento da deformação plástica principal maior \\
\hline$d \varepsilon_{2}^{p}$ & Incremento da deformação plástica principal intermediaria \\
\hline$d \varepsilon_{3}^{p}$ & Incremento da deformação plástica principal menor \\
\hline$\sigma_{n}$ & Tensão normal ao plano de ruptura \\
\hline$\Delta \varepsilon_{i}$ & Incremento das deformações principais \\
\hline$\Delta \varepsilon_{i}^{e}$ & incrementos das deformações principais elásticas \\
\hline$\Delta \varepsilon_{i}^{p}$ & incrementos das deformações principais plásticas \\
\hline$f^{s}$ & Função de plastificação de cisalhamento \\
\hline$f^{t}$ & Função de plastificação de tração \\
\hline$\sigma_{t}$ & Resistência à tração \\
\hline$g^{s}$ & Função de potencial plástico de cisalhamento \\
\hline$g^{t}$ & função de potencial plástico de tração \\
\hline$c_{i}$ & Coesão inicial \\
\hline$c_{r}$ & Coesão residual \\
\hline$c_{m o b}$ & Coesão mobilizada \\
\hline
\end{tabular}




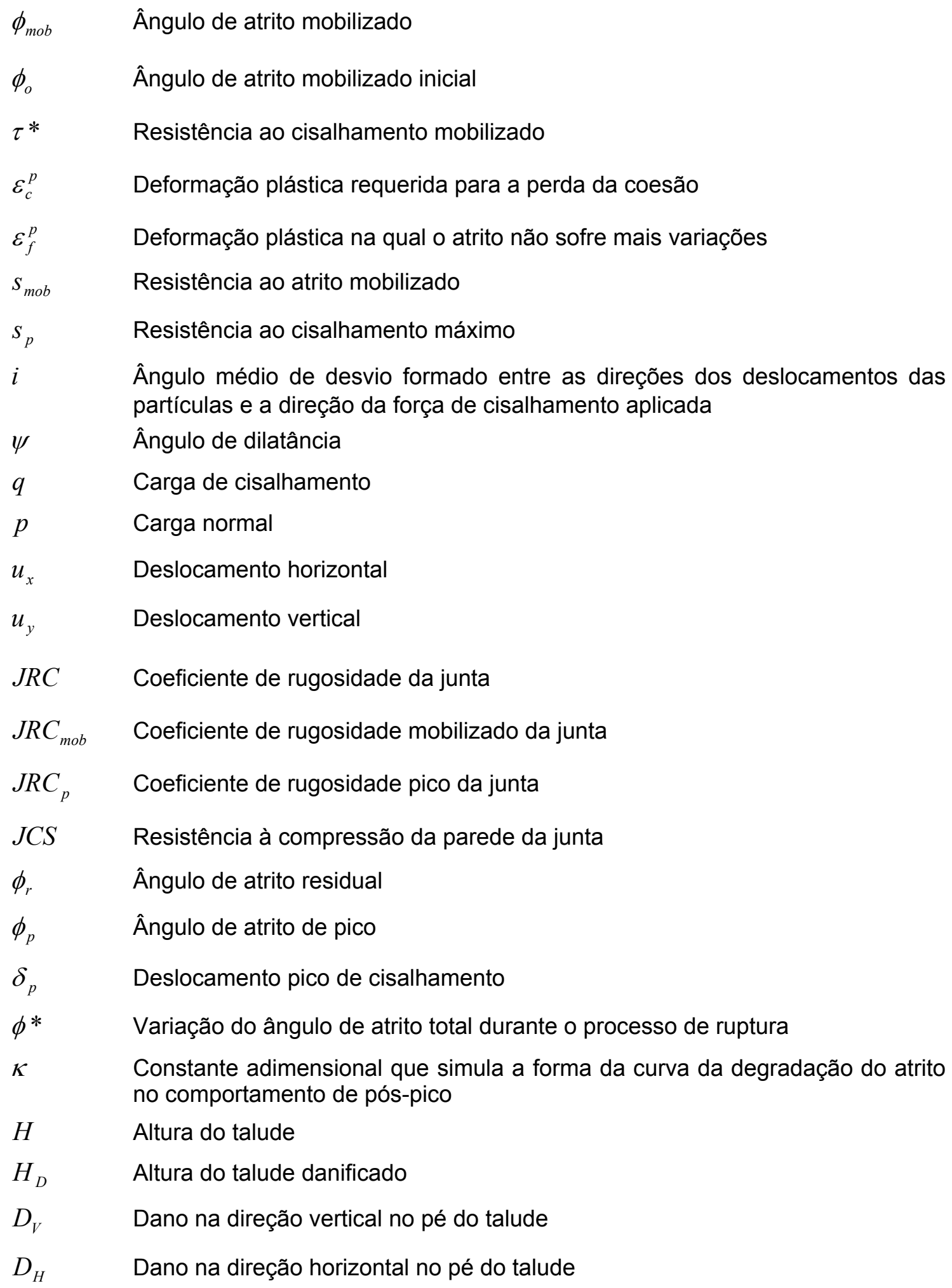




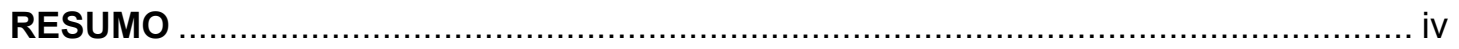

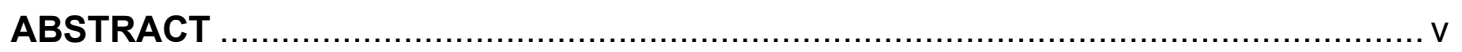

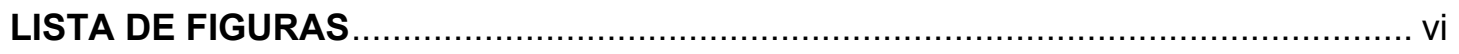

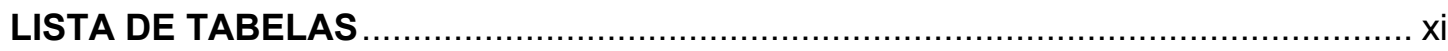

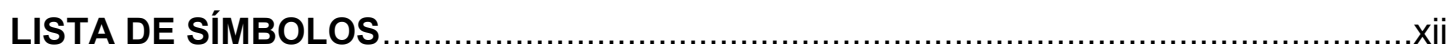

SUMÁRIO

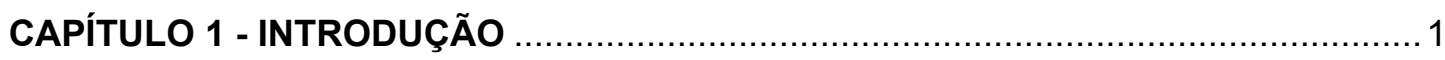

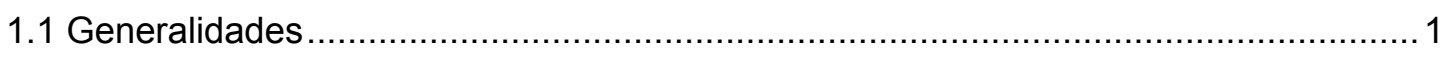

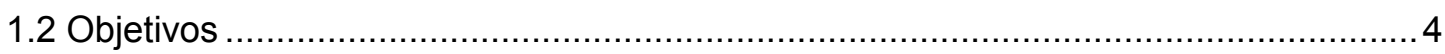

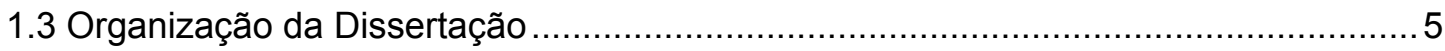

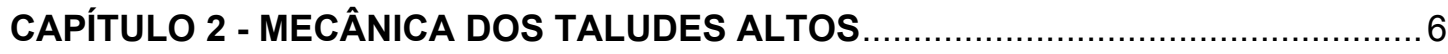

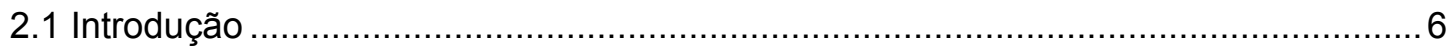

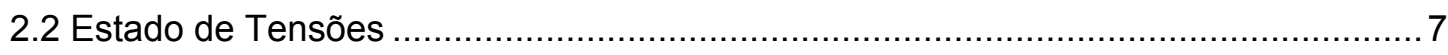

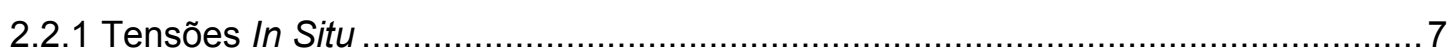

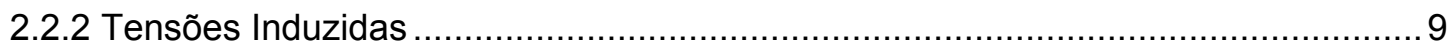

2.2.3 Água Subterrânea e Tensões Efetivas................................................................ 10

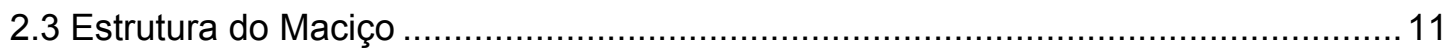

2.4 Resistência de Rochas ................................................................................ 13

2.4.1 Resistência da Rocha Intacta e das Descontinuidades ...................................... 13

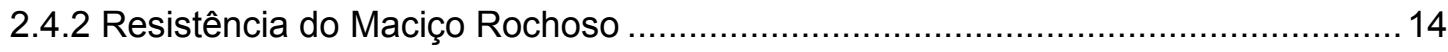

2.4.3 Critério de Ruptura Generalizado de Hoek-Brown ................................................ 15

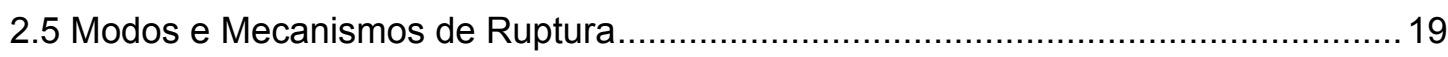

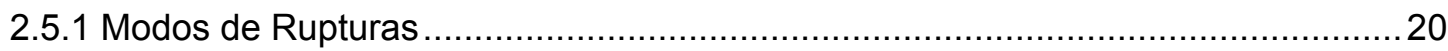

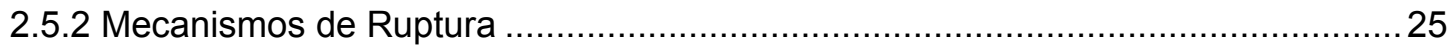

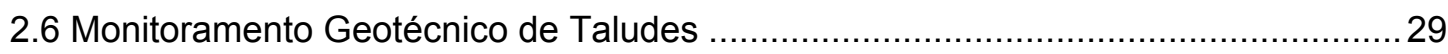

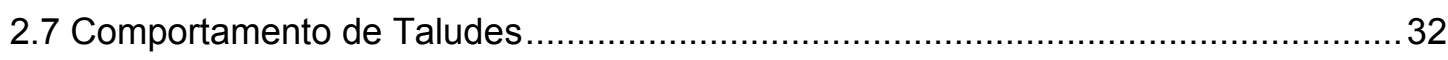

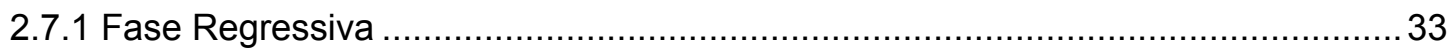

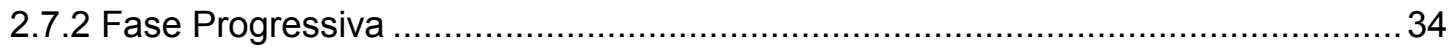

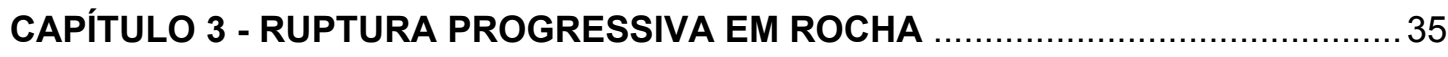

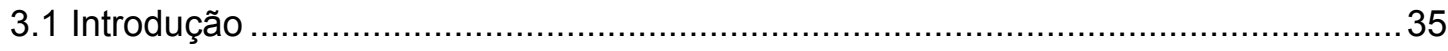

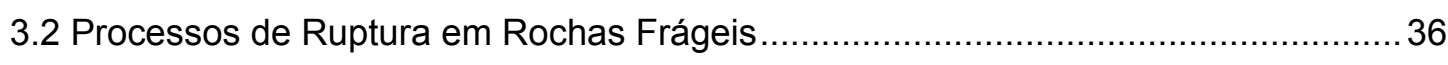


3.3 Mobilização das Componentes da Resistência Durante a Ruptura .......................... 40

3.4 Algumas Relações entre Ensaios de Laboratório e osTaludes ...................................45

CAPÍTULO 4 - MODELAGEM NUMÉRICA: APROXIMAÇÃO DE MEIO CONTINUO .. 47

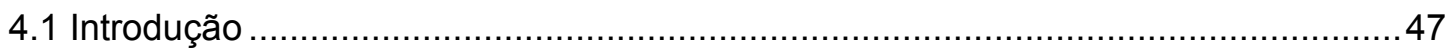

4.2 Plasticidade em Análise de Rupturas de Rocha …................................................. 49

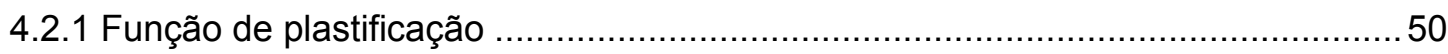

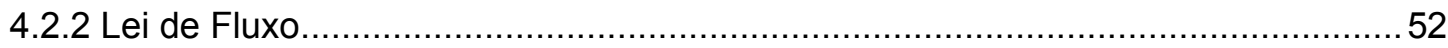

4.2.3 Parâmetro de Endurecimento/Amolecimento ...................................................52

4.3 Critério de Ruptura de Mohr-Coulomb ............................................................. 53

4.4 Modelo de Elasto-Plástico de Mohr-Coulomb ….................................................5

4.4.1 Funções de plastificação e de potencial plástico .................................................55

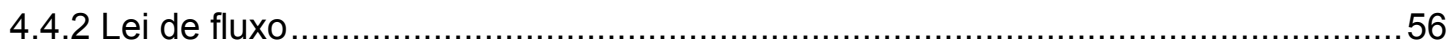

4.5 Modelo de Amolecimento da coesão e de Endurecimento do atrito por deformação

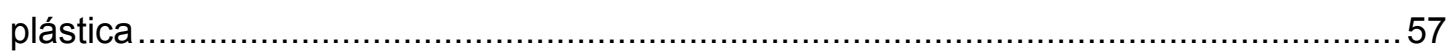

4.5.1 Amolecimento da Coesão por deformação plástica ..............................................60

4.5.2 Endurecimento do atrito por deformação plástica ..............................................61

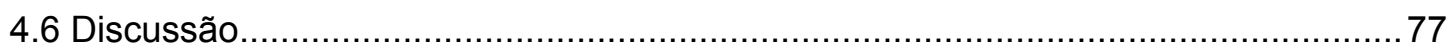

CAPÍTULO 5 - MODELAGEM NUMÉRICA DE TALUDES ALTOS $\ldots \ldots \ldots \ldots \ldots \ldots \ldots \ldots \ldots . . . . . . . . . . . . . . . .1$

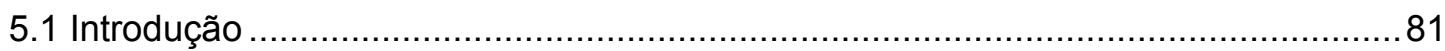

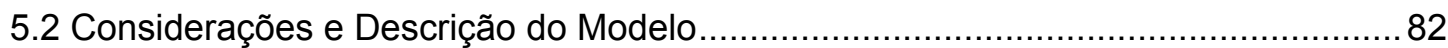

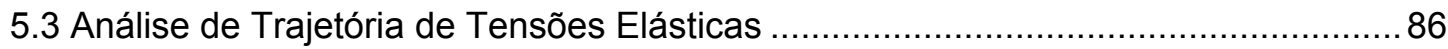

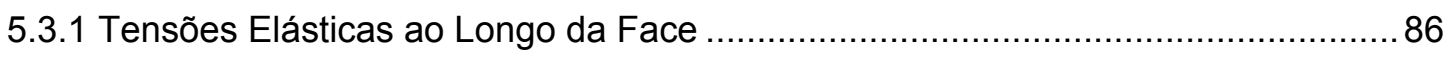

5.3.2 Tensões Elásticas ao Longo da Superfície de Ruptura .......................................91

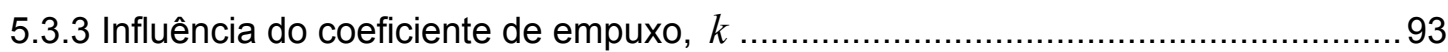

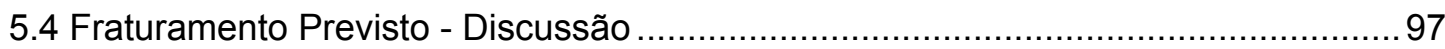

5.5 Análise com o Modelo de Amolecimento da coesão e de Endurecimento do atrito por

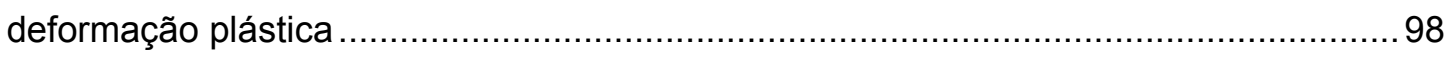

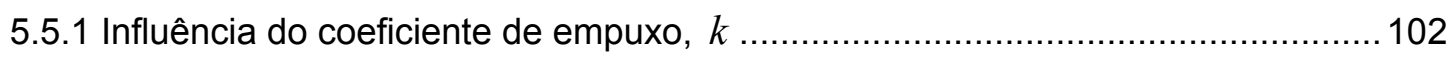

5.6 Avaliação do Fator de Segurança ................................................................. 107

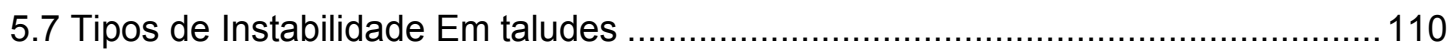

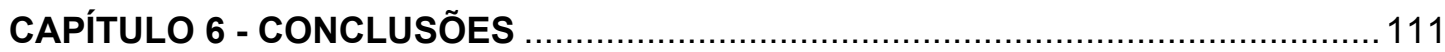

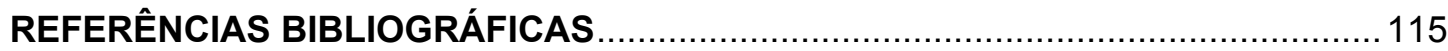




\section{Capítulo 1}

\section{Introdução}

\subsection{Generalidades}

Grandes escavações a céu aberto são feitas com o objetivo de extrair mineral. Atualmente, minerações a céu aberto de grande porte vêm alcançando alturas de escavação superiores a 600 metros. Justificados pela necessidade de obter o maior ganho econômico possível através da extração de minério, os taludes finais tornam-se íngremes, de tal forma que a extração do material estéril diminui. Conforme mostra a literatura, muitas minas foram projetadas prevendo-se para o futuro taludes globais com alturas superiores a $1100 \mathrm{~m}$ (HOEK et al., 2000a e CALL et al., 2000).

Em mineração a céu aberto, a configuração geométrica da cava vai depender basicamente da distribuição espacial do corpo mineral, em conjunto com as características geomecânicas do maciço rochoso. Como exemplo, mostra-se na FIGURA 1.1 a configuração dos taludes de uma mina na qual se observa: o talude de bancada, o talude inter-rampa e o talude global, os quais obedecem a aspectos geométricos. Pode-se dizer que, quanto mais íngreme se mostra o talude, menor é a remoção do material estéril, com custo de extração baixo. No entanto, com o acréscimo dos ângulos de taludes, tem-se o acréscimo do risco de instabilidade. Além disso, com o ganho da altura destes taludes devido ao processo de escavação, resulta igualmente o acréscimo do risco de instabilidade.

$\mathrm{Na}$ avaliação da estabilidade de taludes, algumas metodologias são empregadas, tais como: método empírico, análise por equilíbrio limite, análise probabilística e a modelagem numérica. 


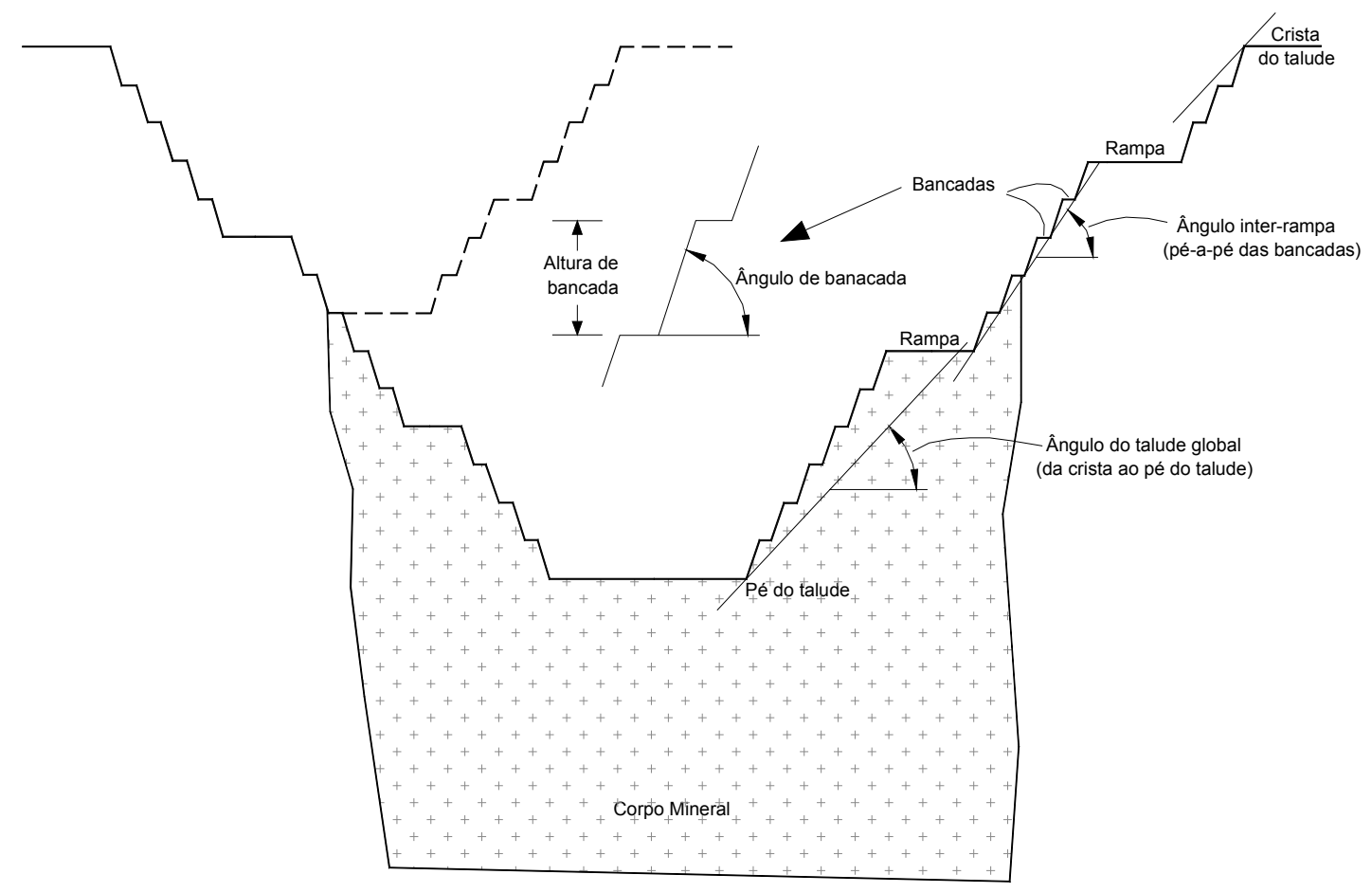

FIGURA 1.1 Configuração dos taludes numa mina a céu aberto.

Dos métodos supramencionados, a literatura mostra um grande número de trabalhos, onde se avalia a estabilidade através do método de equilíbrio limite. Este método assume como hipótese um tipo de ruptura e um critério de ruptura, na maioria dos casos o de Mohr-Coulomb. Neste método, a deformação do material não é levada em consideração, e a condição de equilíbrio é normalmente satisfeita pelo equilíbrio de forças e momentos. Um outro fato é que os fatores de segurança são sensíveis a pequenas mudanças dos parâmetros de resistência. No entanto, este método pode ser bem aplicado em taludes onde a ruptura é condicionada por descontinuidades persistentes, formando, assim, rupturas do tipo planar, do tipo cunha e por tombamento.

Por outro lado, salienta-se que também é de grande importância uma boa estimativa da resistência do maciço rochoso, já que os resultados das análises são altamente dependentes dos valores da resistência estimada. Assim, conforme as análises de sensibilidade feitas por Nunes et al. (2002), o campo de deslocamentos é influenciado por pequenas variações dos parâmetros de entrada, tais como as propriedades elásticas e de resistência do maciço.

As possíveis rupturas esperadas em taludes altos estariam controladas por descontinuidades individuais, estas podendo afetar a estabilidade em nível de bancada e controladas pela estrutura do maciço rochoso no seu conjunto podendo afetar ao talude 
global, assim resultando numa ruptura sem controle estrutural. No entanto, há possibilidades de que existam rupturas de grande porte que estejam controladas por descontinuidades persistentes que afetariam parte significativa do talude global. Porém, não só as estruturas maiores podem controlar completamente a estabilidade, mas também os maciços podem se apresentar muito complexos, numa situação onde vários fatores influenciariam ou condicionariam a estabilidade (HOEK et al., 2000b). Alguns destes fatores ou aspectos estruturais são apresentados na FIGURA 1.2.

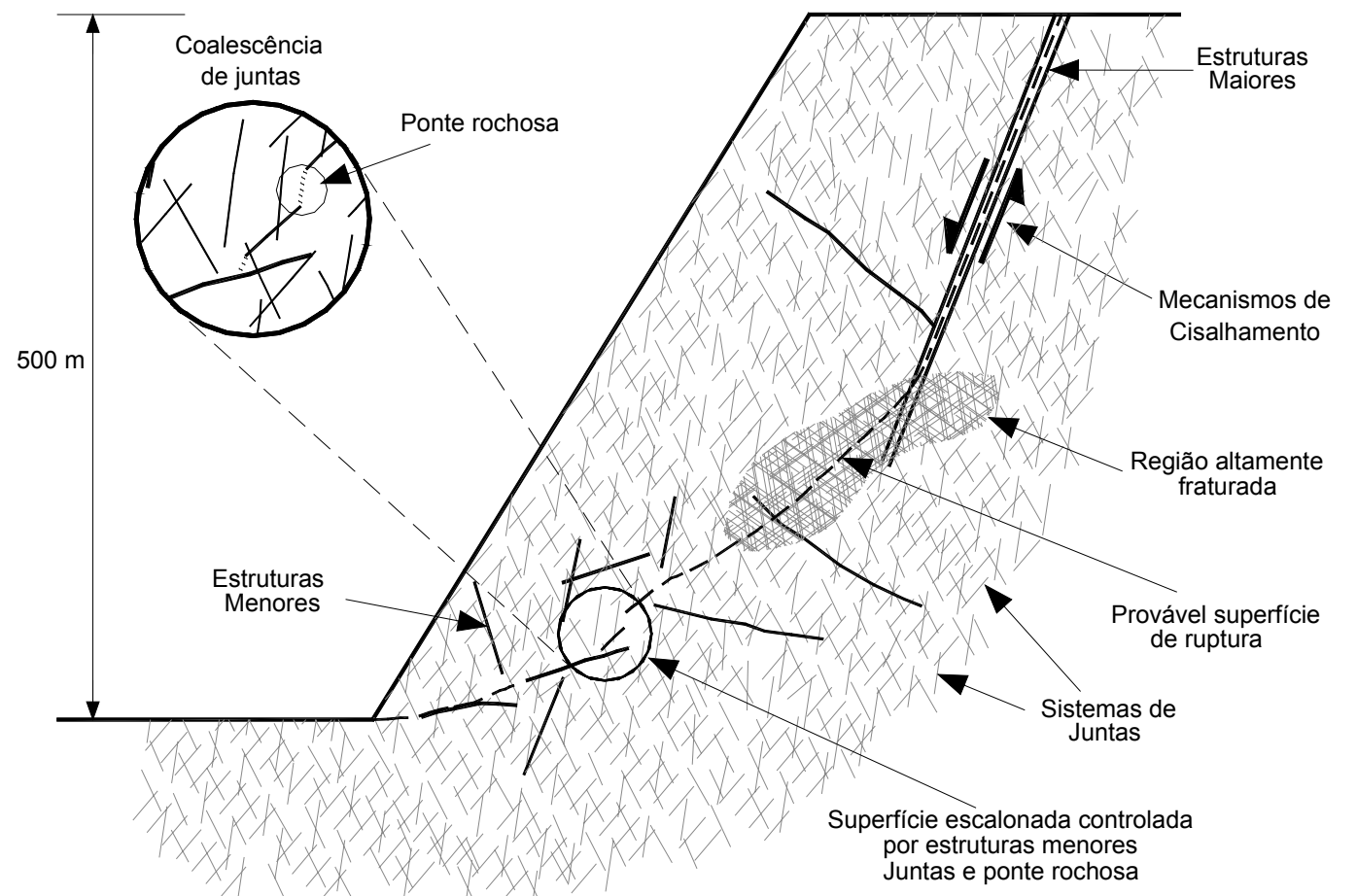

FIGURA 1.2 Provável superfície de ruptura em taludes altos, envolvendo vários fatores estruturais.

Conforme visto na FIGURA 1.2, é provável que a superfície de ruptura num maciço rochoso não seja resultante de um processo tão simples. As prováveis superfícies de ruptura poderiam envolver não só mecanismos de cisalhamento ao longo de um plano préexistente, mas podem também estar compostas de várias descontinuidades como juntas separadas por pontes rochosas, formando-se, assim, a superfície de ruptura pela propagação destas juntas e produzindo coalescência. Por fim, ressalta-se que uma provável superfície de ruptura estaria governada por estruturas maiores (descontinuidades persistentes), estruturas menores (sistemas de juntas), pontes rochosas (rocha intacta) e regiões altamente fraturadas, onde se desenvolveriam mecanismos de cisalhamento ao longo das descontinuidades e coalescência de juntas nas pontes rochosas. 
Por outro lado, outros fatores também podem influenciar na estabilidade de taludes altos, diminuindo principalmente a resistência do maciço rochoso, tais como: a água subterrânea, forças de origem sísmica, dano induzido por desmonte, influência de concentração de tensões induzidas devido às mudanças da geometria da cava. Estes fatores em alguma porcentagem danificam o maciço rochoso, o que pode se dar pela criação de novas fraturas.

Segundo SJÖBERG (2000), "infelizmente, mecanismos de ruptura em taludes altos, especialmente em rochas duras e em rochas fraturadas, são geralmente pouco entendidos e/ou conhecidos. Poucos taludes de mineração entre $300 \mathrm{~m}$ e $500 \mathrm{~m}$ de altura romperam". Segundo aquele autor, os assuntos mais urgentes a serem resolvidos são (a) conhecer as condições para ocorrência de diferentes rupturas, (b) conhecer as condições para a deflagração da ruptura e (c) conhecer a forma e a localização da superfície de ruptura.

As avaliações da estabilidade para bancadas e taludes de moderada altura (100 metros) são bem desenvolvidas. Porém, há uma carência de métodos para a avaliação da estabilidade de taludes altos em rocha. Parece não haver dúvidas também quanto a análises de rupturas condicionadas completamente por planos de fraqueza pré-existentes. O papel do material intacto nas pontes rochosas parece não estar ainda completamente entendido. Também não tem sido considerado o aspecto de concentrações de tensões criadas com o processo evolutivo de escavação. No presente trabalho, descreve-se a importância dos mecanismos ou dos processos de ruptura a serem considerados na avaliação da estabilidade de taludes altos, com ênfase aos mecanismos de ruptura da rocha intacta e sua contribuição à estabilidade, condicionados por concentrações de tensões geradas durante o processo evolutivo da cava.

\subsection{Objetivos}

Dos fatos supramencionados, com a finalidade de entender o processo de ruptura em taludes altos e o que os levariam à condição de ruptura, objetiva-se estudar no desenvolvimento da presente pesquisa os seguintes aspectos:

$\checkmark$ A evolução progressiva das tensões induzidas decorrentes do processo de escavação ou a modificação geométrica da cava;

$\checkmark$ A influência destas tensões induzidas no maciço rochoso, relacionada à modificação da sua resistência como resposta às modificações geométricas;

$\checkmark$ A influência destas tensões induzidas no desenvolvimento de rupturas progressivas. 


\subsection{Organização da Dissertação}

A presente dissertação está organizada em seis capítulos descritos aqui brevemente.

Neste capítulo (capítulo 1), apresenta-se uma breve discussão da complexidade e dos fatores que influenciam na ruptura de taludes altos de mineração a céu aberto e os objetivos da dissertação.

No capítulo 2, apresentam-se as partes conceituais relacionas à mecânica dos taludes altos. São apresentados os fatores que governam a estabilidade de taludes altos de mineração a céu aberto. Os modos e mecanismos de ruptura são descritos em detalhe. Aspectos referentes ao monitoramento geotécnico e comportamento de taludes também são descritos.

O capítulo 3 apresenta os mecanismos ou os processos de ruptura em rochas frágeis observados e reportados por diversos pesquisadores. A mobilização não simultânea das componentes de resistência (coesão e atrito) é descrita. Estudos prévios em rochas frágeis sustentam a perda da resistência coesiva enquanto o atrito se mobiliza.

O capítulo 4 apresenta uma discussão sobre a implementação do modelo de amolecimento da coesão e de endurecimento do atrito por deformação plástica (dano) com aproximação de meio continuo. Este modelo está baseado no modelo proposto por VERMEER e DE BORST (1984), no qual foi possível implementar a mobilização não simultânea das componentes de resistência e que ao mesmo tempo está relacionada à danificação. Foi mostrado que o modelo pode simular apropriadamente o comportamento mecânico de um corpo de prova quando submetido a cargas de compressão.

O capítulo 5 apresenta resultados de simulações numéricas de taludes altos de mineração a céu aberto. Foi considerada uma escavação em estágios simulando o avanço da escavação. Tais simulações foram feitas com modelos elástico linear e elasto-plástico de amolecimento da coesão e de endurecimento do atrito por deformação plástica. Foi evidenciada a influência do histórico de tensões induzidas na degradação da resistência de maciços rochosos durante o processo evolutivo de escavação de uma mina a céu aberto. A quantificação da danificação do maciço rochoso ao longo da face foi possível usando o modelo elasto-plástico de amolecimento da coesão e de endurecimento do atrito por deformação plástica. Foi feita uma avaliação aproximada da segurança mostrando a grande importância da perda de resistência por concentração de tensões.

Finalmente, no capítulo 6, apresentam-se as conclusões gerais do trabalho. 


\section{Capítulo 2}

\section{Mecânica dos Taludes Altos}

\subsection{Introdução}

O comportamento mecânico de taludes altos pode ser influenciado por diferentes fatores, tais como os apresentados na FIGURA 2.1.

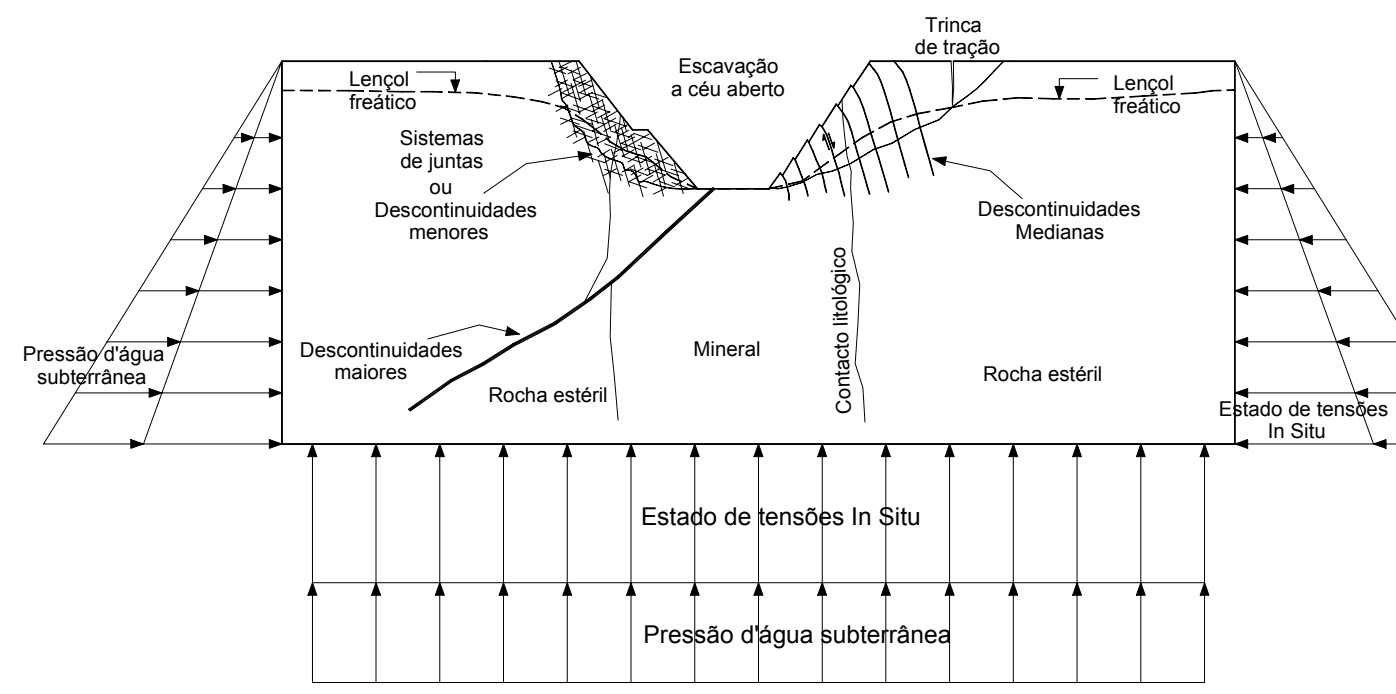

FIGURA 2.1 Fatores que influenciam o comportamento do maciço rochoso.

A partir da avaliação qualitativa de várias rupturas ocorridas em minas a céu aberto, é possível dizer que, são vários os fatores que influenciam tanto o comportamento como a avaliação da estabilidade de taludes, conforme a FIGURA 2.1. Segundo Stacey (1968), os seguintes fatores governam a estabilidade de taludes a céu aberto:

$\checkmark$ O estado de tensões In Situ e as tensões induzidas decorrentes da escavação; 
$\checkmark$ O maciço rochoso: rocha intacta, descontinuidades, zonas de cisalhamento, estrutura do maciço;

$\checkmark$ A resistência do maciço rochoso: rocha intacta, juntas, falhas;

$\checkmark$ A geometria da cava: ângulo de inclinação dos taludes;

$\checkmark$ A aceleração sísmica devido ao desmonte e eventos sísmicos;

$\checkmark$ As condições climáticas, e

$\checkmark$ O tempo.

\subsection{Estado de Tensões}

As tensões decorrentes das forças atuantes no maciço rochoso, comparadas com a sua resistência, condicionam a estabilidade. Segundo HERGET (1988), as tensões encontradas no maciço rochoso podem ser agrupadas de acordo com a sua origem em: tensões iniciais, virgens ou in situ, na etapa de pré-escavação, e as tensões induzidas na etapa das escavações decorrentes de mudanças de geometria. As tensões in situ resultam da combinação de:

$\checkmark$ Tensões gravitacionais, devido ao peso próprio das rochas sobrejacentes;

$\checkmark$ Tensões tectônicas, devido a forças geradas por processos orogênicos e/ou tectônicos;

$\checkmark$ Tensões residuais;

$\checkmark$ Tensões devidas a glaciações passadas, e;

$\checkmark$ Tensões termais.

Assume-se que as tensões gravitacionais e as tectônicas são as maiores contribuintes para as tensões iniciais.

\subsubsection{Tensões In Situ}

A tensão vertical pode ser estimada em regiões de topografia plana pela relação seguinte:

$$
\sigma_{v}=\gamma . z
$$

onde:

$\sigma_{v}:$ Tensão vertical a uma profundidade $z$;

$\gamma:$ Peso específico;

$z$ : Profundidade. 
De acordo com a equação 2.1, a tensão vertical é considerada como tendo um acréscimo linear com a profundidade. Isto pode ser assumido em alguns tipos de análises, como as apresentadas neste trabalho. A validade da equação 2.1 é sustentada por medidas feitas em várias minas e obras civis (HOEK, 2000).

A tensão horizontal é mais difícil de ser quantificada devido à atuação das tensões tectônicas. Em regiões de alta atividade tectônica, tais como nos Andes da América do Sul, as tensões virgens horizontais são tipicamente maiores que as tensões verticais. A tensão horizontal virgem pode ser estimada pela equação 2.2 a seguir:

$$
\sigma_{h}=k \cdot \sigma_{v}
$$

onde:

$k$ : Coeficiente de empuxo;

$\sigma_{h}:$ Tensão horizontal.

Medidas de tensões horizontais evidenciaram que $k$ tende a ser maior para profundidades rasas e que diminui com a profundidade (HOEK e BROWN, 1980; HERGET, 1988). SHEOREY (1994) desenvolveu um modelo de tensão termo-elastoestático da terra, na qual considerou a curvatura da crosta terrestre e a variação das constantes elásticas, a densidade e os coeficientes de expansão termal da crosta e do manto. Como resultado do modelo, aquele autor obteve uma equação simplificada para a estimativa do $k$ (equação 2.3 ):

$$
k=0,25+7 E_{h}\left(0,001+\frac{1}{z}\right)
$$

onde, $z$ é a profundidade em metros e $E_{h}$ é o módulo de deformabilidade medido na direção horizontal em GPa.

Segundo estudos de HOEK e BROWN (1980); HERGET (1988) e SHEOREY (1994), foi mostrado que as tensões horizontais são notavelmente maiores que as verticais para profundidades menores que $1000 \mathrm{~m}$. Este fato foi explicado pela atuação da componente tectônica na crosta.

A grande maioria das minas a céu aberto que foram revisadas encontra-se localizadas em regiões orogênicas, tal como nos Andes da América do Sul, o que permite assumir o valor de $k$ maior que um. 


\subsubsection{Tensões Induzidas}

Em escavações a céu aberto, o estado de tensões virgens é perturbado conforme o avanço da escavação. O vazio criado pela modificação da geometria força as tensões a se redistribuírem ao longo da borda da cava, conforme mostrado na FIGURA 2.2.

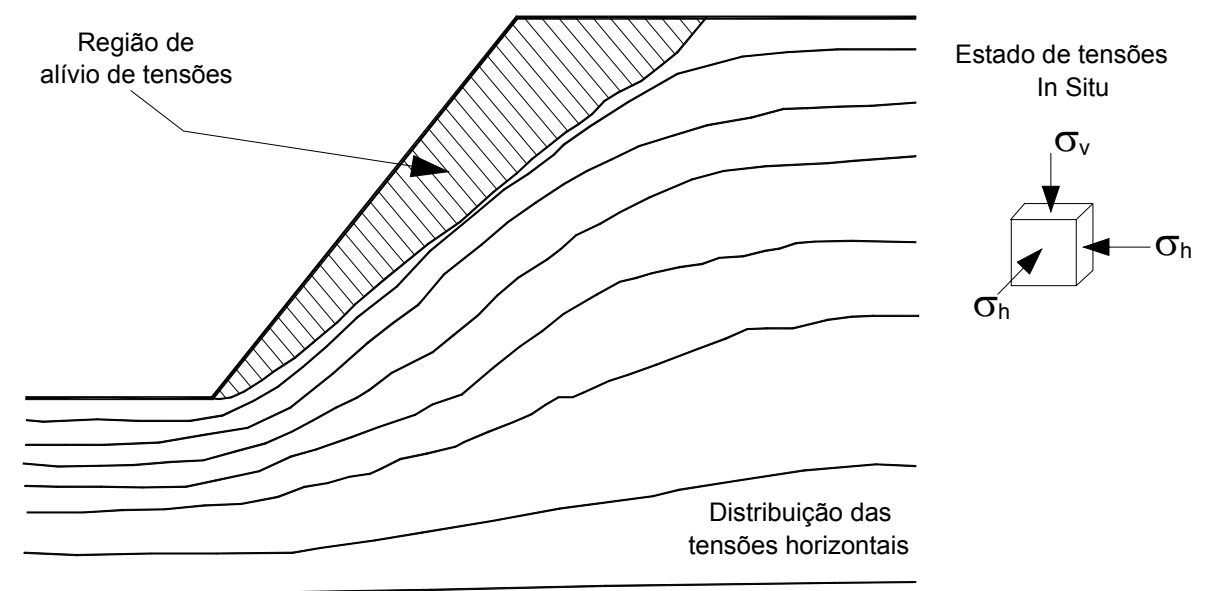

FIGURA 2.2 Redistribuição das tensões com a mudança de geometria.

A literatura apresenta estudos de tensões em taludes que explicam a redistribuição das tensões após a escavação. Assim, de acordo com a FIGURA 2.2, desenvolve-se uma zona de alívio de tensões na face do talude, na qual, segundo SJÖBERG (1999) e HOEK et al. (2000a), a redistribuição das tensões devida à remoção do material resulta num desconfinamento do maciço rochoso. Nesta região, a tensão vertical diminui, provocando, assim, a abertura de fendas pré-existentes. Isto ocorre devido ao decréscimo da tensão normal (diminuição da resistência ao cisalhamento), caracterizando uma região com muitos problemas de escorregamentos.

Segundo DODD e ANDERSON (1971), COATES (1977), STACEY (1970) e SJÖBERG (1999), na região do pé do talude há concentração de tensões (acréscimo de tensões compressivas e de cisalhamento) que poderiam gerar instabilidade por tensões induzidas. SJÖBERG (1999), HOEK et al. (2000a) e CALL et al. (2000) afirmaram que, com o acréscimo da altura dos taludes, as tensões também se incrementam, havendo assim, acréscimo de risco na ocorrência de rupturas.

Os estudos de DODD e ANDERSON (1971), STACEY $(1970,1973)$ e COULTHARD et al. (1992) mostraram a existência de esforços de tração desenvolvidos na região da crista do talude. Estes esforços são maiores, quanto mais elevadas forem as tensões horizontais virgens e quanto mais íngremes os ângulos do talude. Conforme os 
estudos de HUSTRULID e KUCHTA (1995), a variação da tensão horizontal inicial só afeta o estado de tensões da região do pé do talude, ao passo que a região da face do talude estaria sujeita apenas à carga de gravidade. Por outro lado, acredita-se que na face do talude a tensão horizontal não dependa da inicial, após a escavação. Entretanto, quanto maior a inicial, maior o decréscimo ou o alívio de tensões e maior será o efeito de abertura de juntas pré-existentes, e eventualmente maior o dano ao material intacto, dependendo da trajetória de tensões até o alívio.

SJÖBERG (1999) resume que existem poucos estudos sobre o estado de tensões em escavações a céu aberto, os quais foram aprendidos através de análises fotoelásticas e de análises numéricas como as de STACEY $(1970,1973)$.

A literatura mostra que, recentemente, a análise numérica está sendo utilizada para o estudo do comportamento de taludes, mas ainda não se consegue reproduzir todos os fenômenos envolvidos. O conhecimento do estado de tensões num talude é muito importante, já que conforme a sua magnitude, poderia gerar algum tipo de manifestação como a deformação do maciço rochoso, a qual pode-se traduzir em dano e instabilidade.

\subsection{3 Água Subterrânea e Tensões Efetivas}

O estado de tensões num talude depende também da presença de água subterrânea no maciço rochoso. A localização do lençol freático não perturbado (préescavação) depende de características tais como: a topografia, a localização da cava em relação às fontes (como os rios e lagos), a infiltração d'água de chuvas, entre outros. Um fato a se salientar é que o lençol freático inicial muda em relação ao avanço da escavação ou com as mudanças de geometria.

O maciço rochoso que se encontra abaixo do lençol freático está submetido a pressões de água, que atuam nas descontinuidades pré-existentes e reduzem a tensão efetiva, que como conseqüência reduzem a resistência ao cisalhamento na provável superfície de ruptura (tensão normal reduzida). Adicionalmente, pode-se ter efeitos secundários pela presença d'água no maciço, de modo que alguns minerais podem reagir desfavoravelmente, reduzindo, desta forma, a resistência do material de preenchimento das descontinuidades. Ressalta-se que este efeito pode ser ainda mais crítico nas falhas, em que se tem grande quantidade de material de preenchimento, muitas vezes expansivo em presença d'água.

A permeabilidade do maciço rochoso pode ser significativamente alta devido ao fato que o fluxo se dá através das descontinuidades pré-existentes e por serem elas 
numerosas. A permeabilidade de uma descontinuidade individual é sensível à variação da abertura da junta, e depende da tensão normal atuante. O mesmo fenômeno pode ocorrer em maciços rochosos fraturados. Assim, na região de alívio de tensões, o fluxo d'água será maior permitindo mudanças do lençol freático, e também mudanças das tensões efetivas. Por outro lado, pode-se esperar um decréscimo da permeabilidade em regiões de altas tensões de confinamento, como na região do pé do talude (SHARP et al., 1977).

\subsection{Estrutura do Maciço Rochoso}

A estrutura do maciço rochoso é sem dúvida um dos fatores mais importantes que governa a estabilidade do talude. As distribuições espaciais dos diferentes tipos de rocha e as suas descontinuidades formam o maciço rochoso. Na FIGURA 2.3, apresenta-se uma seção típica de um maciço rochoso, que é atravessado por diferentes descontinuidades, tais como falhas e sistemas de juntas. Além disso, podem ocorrer vários tipos de litologias com diferentes graus de fraturamento.

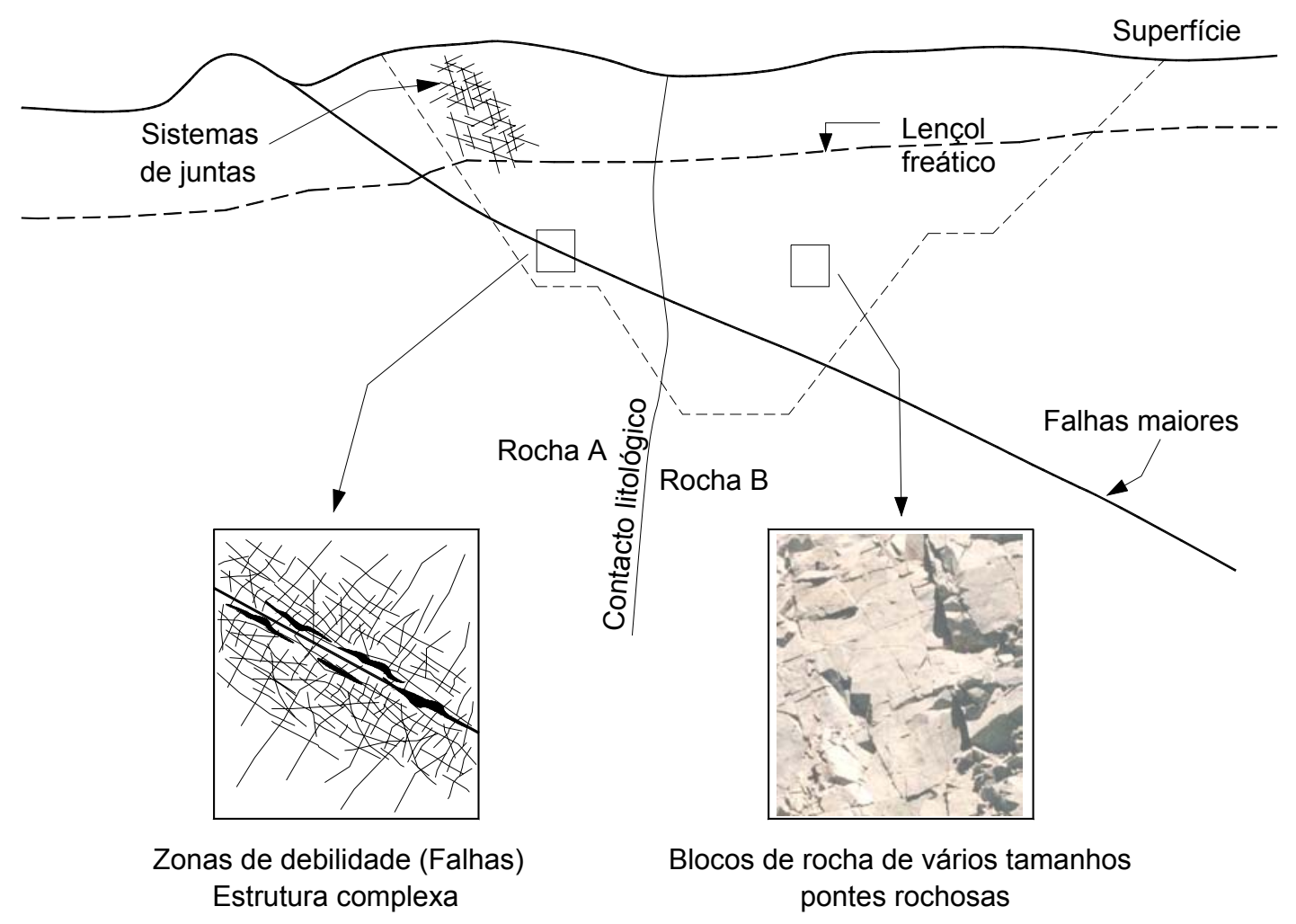

FIGURA 2.3 Exemplo da estrutura do maciço rochoso.

Conforme a FIGURA 2.3, salienta-se: (1) A importância das descontinuidades persistentes, que atuam como zonas de fraquezas, podendo eventualmente governar a estabilidade; (2) A fábrica (estrutura, trama) consiste em blocos limitados por juntas, 
fraturas ou fissuras, assim, a distância entre estes tipos de descontinuidades determina o tamanho dos blocos. As características destes blocos, tais como a persistência das juntas que os delimitam, a resistência ao cisalhamento das faces ou das juntas, a resistência da rocha intacta, o tamanho dos blocos (grau de fraturamento) entre outras características, influenciam na resistência do maciço rochoso. Salienta-se que, conforme a persistência destas juntas, podem existir pontes rochosas, as quais contribuem com a resistência coesiva do maciço.

Segundo SJÖBERG (1999), para taludes altos, as descontinuidades de maior interesse são: (1) Descontinuidades aproximadamente da mesma dimensão dos taludes, como falhas e zonas de cisalhamento e (2) Descontinuidades pequenas, que fazem parte da fábrica do maciço rochoso. ZEA (2002) divide as descontinuidades conforme a sua continuidade e a sua influência na estabilidade dos taludes altos em: (1) descontinuidades maiores, que compreendem as falhas regionais maiores que 1 quilômetro (falhas que podem atravessar completamente a cava); (2) descontinuidades medianas, com persistência de 20 até $1000 \mathrm{~m}$, que podem comprometer a estabilidade de várias bancadas, até o talude global, conforme a sua disposição geométrica em relação ao talude, e (3) descontinuidades menores, com persistência menor que $20 \mathrm{~m}$; neste grupo estariam tanto as falhas menores de $20 \mathrm{~m}$ como os sistemas de juntas. Este tipo de descontinuidade governa a estabilidade ao nível de bancada ao mesmo passo que também forma parte da fábrica do maciço.

HOEK, (1971), HOEK e BRAY (1981) afirmaram que a orientação das descontinuidades pré-existentes em relação à orientação do talude (condições cinemáticas de ruptura) pode ter impacto no comportamento dos taludes em rocha. Isto está baseado no fato de que as descontinuidades são planos de fraqueza no maciço rochoso.

As descontinuidades no maciço rochoso estão presentes em todas as escalas, tendo-se desde as micro-fissuras até as falhas regionais de vários quilômetros. $\mathrm{Na}$ FIGURA 2.4, apresenta-se uma classificação dos diferentes tipos de descontinuidades conforme a sua persistência. Salienta-se que cada tipo de descontinuidade influencia no comportamento do material para uma determinada escala, assim, as micro-fissuras e fissuras influenciam no comportamento do corpo de prova, enquanto as juntas, falhas, os planos de acamamento e planos de cisalhamento influenciam no comportamento do maciço rochoso, que no caso pode ser o talude global. As descontinuidades chamadas de falhas medianas e maiores podem governar a estabilidade nos taludes altos. Assim também, as juntas que são formadoras de fábrica do maciço rochoso gerariam outro tipo 
de mecanismo em conjunto com as pontes rochosas. Finalmente, conforme apresentado na FIGURA 1.2, vários fatores estruturais podem governar a estabilidade, tendo cada uma delas a sua devida importância.

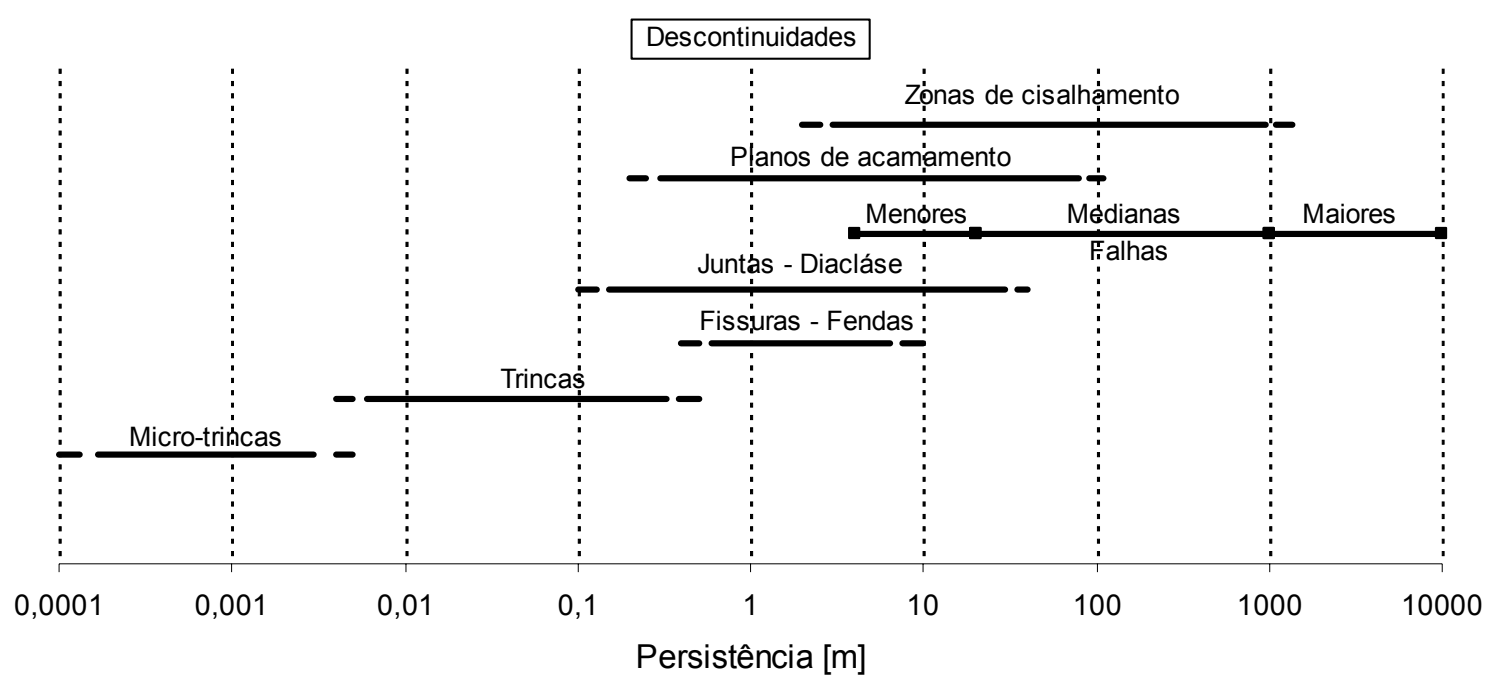

FIGURA 2.4 Tipos de descontinuidades conforme a sua persistência.

Adicionalmente, SJÖBERG (1999) salienta o efeito de escala, comparando o tamanho das descontinuidades em relação à altura do talude (30, 90 e $500 \mathrm{~m})$. Para este efeito, ele considera dois sistemas de juntas com persistências entre 8 e 10m, pontes rochosas entre 3 e $5 \mathrm{~m}$ e espaçamentos entre 3 e $7 \mathrm{~m}$. O resultado mostra que, com a mesma distribuição de juntas, para taludes pequenos $(30 \mathrm{~m})$, o maciço se mostra pouco fraturado; já para taludes altos (500 m), o maciço se mostra altamente fraturado. Assim, o tamanho do bloco unitário é muito pequeno comparado à altura do talude, fato que talvez permita afirmar que o maciço pode comportar-se como um meio contínuo. Por outro lado, num maciço rochoso, pode-se ter mais de dois sistemas de juntas, com espaçamentos e persistências que podem ser muito menores que os apresentados por aquele autor.

\subsection{Resistência de Rochas}

\subsubsection{Resistência da rocha intacta e das descontinuidades}

Sabe-se que o maciço rochoso é composto pela rocha intacta e pelas descontinuidades. Na literatura, encontram-se estudos sobre a resistência da rocha intacta e das descontinuidades, de modo que podem ser consideradas como bem compreendidas. A resistência das descontinuidades planas pode ser bem descrita pelo critério de resistência de Coulomb. Para descontinuidades com superfícies rugosas, critérios como o 
de PATTON (1966) podem ser mais aplicáveis. BARTON (1976) e BARTON e CHOUBEY (1977) desenvolveram um critério de ruptura empírico de cisalhamento que inclui a rugosidade da superfície das descontinuidades e a resistência compressiva das paredes. Aqueles autores também sugeriram métodos para a estimativa dos parâmetros de rugosidade, $J R C$, e resistência do material das paredes, $J C S$, os quais são usados na estimativa da resistência ao cisalhamento das descontinuidades.

No maciço rochoso, a rocha intacta ocorre como pontes rochosas entre as descontinuidades. O comportamento mecânico da rocha intacta tem sido bem estudado, contudo, o comportamento das pontes rochosas entre as descontinuidades é menos entendido. Segundo EINSTEIN et al. (1983) e EINSTEIN (1993), os mecanismos que inicialmente se desenvolvem nas pontes rochosas são mecanismos de tração (ruptura em Modo I), ao passo que mecanismos de cisalhamento (ruptura em Modo II) se desenvolveriam como um fenômeno secundário, formando-se assim, eventualmente, fraturas de cisalhamento pela união de duas descontinuidades. Recentemente, HAJIABDOLMAJID et al. (2002), a partir do trabalho de LAJTAI (1969), afirmam que estes mecanismos de tração são os que governam a resistência da rocha em baixas tensões de confinamento; assim, por este mecanismo se dá a perda da resistência coesiva.

\subsubsection{Resistência do maciço rochoso}

A resistência do maciço rochoso foi menos pesquisada do que a resistência da rocha intacta e das descontinuidades. No entanto, vários estudos mostram que a resistência é significativamente reduzida com o acréscimo do tamanho da amostra. Esta diminuição da resistência em relação ao acréscimo do volume é primariamente devida ao acréscimo do número de descontinuidades pré-existentes no maciço. Conforme a literatura, a resistência do maciço rochoso pode ser estimada através de: (1) classificações geomecânicas, (2) ensaios de grande porte, (3) retro-análise de rupturas, e (4) critérios de ruptura como o de Hoek-Brown, usado em conjunto com as classificações geomecânicas e - GSI (Índice de Resistência Geológico). Sem dúvida, o critério mais conhecido e atualmente usado na avaliação da resistência do maciço rochoso é o critério de ruptura de Hoek-Brown, descrito posteriormente.

Das alternativas de avaliação da resistência do maciço rochoso, os ensaios de grande porte são raramente aplicáveis e possíveis em aplicações de taludes. A retroanálise de rupturas prévias pode ser uma boa alternativa, porque seria possível obter-se parâmetros de resistência mais representativos. No entanto, para isto se requer que 
tenham acontecido rupturas, e o tipo de ruptura deve ser razoavelmente definido. Adicionalmente, os fatores envolvidos na ruptura, tais como a água subterrânea, características do maciço, sismicidade, entre outras, devem ser avaliados adequadamente.

Por outro lado, segundo BIENIAWSKI (1967), um critério de ruptura deve representar os mecanismos de ruptura envolvidos durante o processo de ruptura. No entanto, da mesma forma que o critério de Hoek-Brown, o critério de Mohr-Coulomb não fornece uma descrição verdadeira do processo físico que ocorre durante a ruptura de maciços rochosos de grande porte.

\subsubsection{Critério de ruptura generalizado de Hoek-Brown}

Este critério foi apresentado por HOEK e BROWN (1980) numa tentativa de fornecer dados de entrada para as análises de projetos em escavações subterrâneas. O critério iniciou-se a partir de propriedades da rocha intacta, e em seguida foi expandido para maciços rochosos com a introdução de fatores que considerem as características das descontinuidades do maciço. Os autores buscaram ligar o critério empírico às observações geológicas através da classificação geomecânica ( $R M R$ ) proposta por BIENIAWSKI (1976). O critério original em termos de tensões principais foi definido por:

$$
\sigma_{1}=\sigma_{3}+\sqrt{m \sigma_{3} \sigma_{c}+s \sigma_{c}^{2}}
$$

onde:

$\sigma_{1}:$ Tensão principal maior;

$\sigma_{3}$ : Tensão principal menor;

$m$ e $s$ : Constantes do material, onde $s=1$ para a rocha intacta;

$\sigma_{c}$ : Resistência à compressão simples da rocha intacta.

Com o tempo, o critério teve subseqüentes revisões e atualizações por HOEK e BROWN (1988), onde os autores introduziram maciços rochosos perturbados e não perturbados. HOEK et al. (1992) consideraram nula a resistência à tração do maciço rochoso de qualidade muito pobre. HOEK (1994) introduziu o conceito do critério de ruptura generalizado de Hoek-Brown, no qual a envoltória de Mohr-Coulomb pode ser ajustada por meio de um expoente variável $a$ em lugar do termo da raiz quadrada da equação 2.4. Além das mudanças nas equações, foi considerado que a classificação geomecânica $(R M R)$ não era adequada para relacionar o critério de ruptura às observações geológicas de campo, particularmente para maciços brandos. Isto resultou na introdução do Índice de Resistência Geológico (GSI) por HOEK et al. (1995), que 
posteriormente foi estendido para maciços rochosos brandos. HOEK et al. (1995) apresentam uma relação entre as classificações geomecânicas ( $R M R$ e $\left.Q^{\prime}\right)$ e o índice GSI pelas seguintes equações:

$$
\begin{array}{ll}
G S I=R M R_{76}, \text { para } R M R_{76}>18 & 2.5 \\
G S I=9 \log Q^{\prime}+44, \text { para } R M R_{76}<18 & 2.6 \\
G S I=R M R_{89}-5, \text { para } R M R_{89}>23 & 2.7
\end{array}
$$

onde:

$R M R_{76}$ : Classificação geomecânica de Bieniawski versão 1976;

$R M R_{89}$ : Classificação geomecânica de Bieniawski versão 1989;

$Q^{\prime}=\frac{R Q D}{J_{n}} \cdot \frac{J_{r}}{J_{a}}:$ Índice modificado da Classificação geomecânica de Barton.

O índice GSI parece ser muito qualitativo e está sujeito à comparação entre observações visuais do maciço e tabelas comparativas. As classificações geomecânicas ( $R M R$ e $Q$ ) já estão muito bem descritas, apresentando de forma clara e direta a avaliação da qualidade do maciço rochoso.

HOEK et al. (2002) apresentaram o critério de ruptura generalizado de HoekBrown, expresso pela seguinte equação:

$$
\sigma_{1}^{\prime}=\sigma_{3}^{\prime}+\sigma_{c i}\left(m_{b} \frac{\sigma_{3}^{\prime}}{\sigma_{c i}}+s\right)^{a}
$$

onde:

$\sigma_{1}^{\prime}$ : Tensão efetiva principal maior;

$\sigma_{3}^{\prime}:$ Tensão efetiva principal menor;

$\sigma_{c}$ : Resistência à compressão simples da rocha intacta;

$m_{b}$ : Valor reduzido da constante do material $m_{i}$ ou constante do maciço rochoso; $s$ e $a$ : Constantes para o maciço rochoso.

O valor de $m_{b}$ é dado por:

$$
m_{b}=m_{i} \exp \left(\frac{G S I-100}{28-14 D}\right)
$$

onde:

$m_{i}$ : Constante da rocha intacta; 
GSI : Índice de resistência geológica;

$D$ : Fator de perturbação.

As constantes $s$ e $a$ são obtidas pelas seguintes equações:

$$
\begin{aligned}
& s=\exp \left(\frac{G S I-100}{9-3 D}\right) \\
& a=\frac{1}{2}+\frac{1}{6}\left(e^{\frac{-G S I}{15}}-e^{\frac{-20}{3}}\right)
\end{aligned}
$$

O fator $\mathrm{D}$ depende do grau de perturbação ao qual o maciço rochoso foi submetido devido a danos oriundos de desmonte e da relaxação de tensões. Este fator assume o valor de zero para maciços rochosos não perturbados e de 1 para maciços rochosos bastante perturbados.

A resistência à compressão uniaxial do maciço rochoso $\left(\sigma_{c m}\right)$ é obtida substituindo $\sigma_{3}^{\prime}=0$ na equação 2.8 , obtendo-se:

$$
\sigma_{c m}=\sigma_{c i} \cdot s^{a}
$$

A resistência à tração do maciço rochoso $\left(\sigma_{t m}\right)$ é obtida substituindo $\sigma_{1}^{\prime}=\sigma_{3}^{\prime}=\sigma_{t m}$ na equação 2.8 , obtendo-se:

$$
\sigma_{t m}=-\frac{s \sigma_{c i}}{m_{b}}
$$

As tensões normal e de cisalhamento estão relacionadas com as tensões principais pelas equações publicadas por BALMER (1952) apud HOEK et al. (2002):

$$
\begin{gathered}
\sigma_{n}^{\prime}=\frac{\sigma_{1}^{\prime}+\sigma_{3}^{\prime}}{2}-\frac{\sigma_{1}^{\prime}-\sigma_{3}^{\prime}}{2} \cdot \frac{\frac{d \sigma_{1}^{\prime}}{d \sigma_{3}^{\prime}}-1}{\frac{d \sigma_{1}^{\prime}}{d \sigma_{3}^{\prime}}+1} \\
\tau=\left(\sigma_{1}^{\prime}-\sigma_{3}^{\prime}\right) \frac{\sqrt{\frac{d \sigma_{1}^{\prime}}{d \sigma_{3}^{\prime}}}}{\frac{d \sigma_{1}^{\prime}}{d \sigma_{3}^{\prime}}+1}
\end{gathered}
$$

onde:

$$
\frac{d \sigma_{1}^{\prime}}{d \sigma_{3}^{\prime}}=1+a m_{b}\left(\frac{m_{b} \sigma_{3}^{\prime}}{\sigma_{c i}+s}\right)^{a-1}
$$


Na grande maioria dos programas geotécnicos, os parâmetros de entrada são os correspondentes ao do modelo de Mohr-Coulomb, sendo necessária a determinação dos parâmetros equivalentes ( $c$ e $\phi$ ) para o maciço rochoso. A determinação destes parâmetros é feita ajustando-se uma relação linear à envoltória não-linear originada pela equação 2.8 para uma faixa de tensão de confinamento definida por $\sigma_{t m}<\sigma_{3}<\sigma_{3 \max }^{\prime}($ HOEK et al., 2002). A coesão $(c)$ e o atrito $(\phi)$ podem ser obtidos a partir das seguintes equações:

$$
\begin{gathered}
\phi^{\prime}=\operatorname{sen}^{-1}\left[\frac{6 a m_{b}\left(s+m_{b} \sigma_{3 n}^{\prime}\right)^{a-1}}{2(1+a)(2+a)+6 a m_{b}\left(s+m_{b} \sigma_{3 n}^{\prime}\right)^{a-1}}\right] \\
c^{\prime}=\frac{\sigma_{c i}\left[(1+2 a) s+(1-a) m_{b} \sigma_{3 n}^{\prime}\right]\left(s+m_{b} \sigma_{3 n}^{\prime}\right)^{a-1}}{(1+a)(2+a) \sqrt{1+\frac{6 a m_{b}\left(s+m_{b} \sigma_{3 n}^{\prime}\right)^{a-1}}{(1+a)(2+a)}}}
\end{gathered}
$$

onde:

$$
\sigma_{3 n}=\frac{\sigma_{3 \max }^{\prime}}{\sigma_{c}}
$$

Nota-se que a tensão de confinamento varia de $\sigma_{t m}$ a $\sigma_{3 \max }^{\prime}$, na faixa que as relações entre o critério de Hoek-Brown e de Mohr-Coulomb são consideradas, onde a tensão $\sigma_{3 \max }^{\prime}$ deve ser determinada para cada caso de análise. HOEK et al. (2002), para casos de taludes, propõem uma relação para a estimativa da tensão de confinamento máxima $\left(\sigma_{3 \max }^{\prime}\right)$ dada pela equação seguinte:

$$
\frac{\sigma_{3 \max }^{\prime}}{\sigma_{c m}^{\prime}}=0,72\left(\frac{\sigma_{c m}^{\prime}}{\gamma \cdot H}\right)^{-0,91}
$$

onde:

$\gamma:$ Peso específico;

$H$ : Altura do talude.

Finalmente, a resistência ao cisalhamento de Mohr-Coulomb $(\tau)$ para uma tensão normal $(\sigma)$ é estimada pela substituição dos valores de c' e $\phi^{\prime}$ na equação de MohrCoulomb:

$$
\tau=c^{\prime}+\sigma \tan \phi^{\prime}
$$


A equação 2.20 em termos de tensões principais é definida por:

$$
\sigma_{1}=\frac{2 c^{\prime} \cos \phi^{\prime}}{1-\operatorname{sen} \phi^{\prime}}+\frac{1+\operatorname{sen} \phi^{\prime}}{1-\operatorname{sen} \phi^{\prime}} \sigma_{3}^{\prime}
$$

Hoek et al. (1995) resumem as características do maciço, nos quais o critério de ruptura de Hoek-Brown pode ser aplicado. Assim, o critério é estritamente aplicável para a rocha intacta ou para maciço rochoso altamente fraturado que pode ser considerado homogêneo e isotrópico. Para casos em que o comportamento do maciço rochoso esteja governado por descontinuidades ou sistemas de juntas, critérios que descrevem a resistência ao cisalhamento de juntas devem ser usados (critério de Barton-Bandis e o critério de Mohr-Coulomb aplicado para descontinuidades).

\subsection{Modos e Mecanismos de Ruptura}

Rupturas em taludes foram inicialmente estudadas para fins de obras civis, mas, nas últimas décadas, taludes que se apresentam em mineração a céu aberto com alturas que superam 600 m (SJÖBERG, 2000; CALL et al., 2000) têm provocado maior interesse em estudo.

No presente trabalho, se faz a diferenciação entre modo e mecanismo de ruptura, o que já tem sido usado na literatura. BIENIAWSKI (1967) introduziu essas terminologias, sendo o modo de ruptura definido como a descrição do aspecto geométrico em que uma ruptura acontece, e o mecanismo de ruptura como os processos que se dão num material no transcurso de carregamento e que, eventualmente, o levam à condição de ruptura. SJÖBERG (1999) fez uso dessa mesma terminologia, aplicando-a para o estudo de taludes. Assim, o modo de ruptura é a descrição macroscópica da forma geométrica em que uma ruptura acontece (como as rupturas planar, em cunha e por tombamento). $O$ mecanismo de ruptura refere-se à descrição do processo físico que acontece em diferentes pontos do maciço rochoso, tal como o começo e a propagação da ruptura através da rocha e que, eventualmente, a conduz ao colapso.

Trabalhos como o de PATTON e DEERE (1971) enfatizaram a definição dos fatores geológicos que controlariam a estabilidade de taludes, os quais se referem basicamente aos aspectos geométricos (modo de ruptura). KENNEDY e NIERMYER (1970) divulgaram os sistemas de monitoramento dos deslocamentos de taludes usados na previsão da ruptura na mina Chuquicamata, no Chile, que serviram para ampliar o conhecimento relativo aos mecanismos de ruptura em taludes. BROADBENT e KO (1972), ZAVODNI e BROADBENT (1978), BROADBENT e ZAVODNI (1982), RYAN e CALL 
(1992) e CALL et al. (2000) analisaram o campo de deslocamentos em taludes de mineração a céu aberto, mostrando os respectivos comportamentos desses taludes como fase progressiva e regressiva (mecanismo de ruptura).

Em taludes, tanto em solos como em rochas, a superfície de ruptura não se desenvolve ao mesmo tempo em toda sua extensão, devendo haver então, um desenvolvimento progressivo da superfície de ruptura (mecanismo de ruptura), o que eventualmente pode conduzir o talude ao colapso (BISHOP, 1967). Adicionalmente, segundo CHOWDHURY (1978), descreve-se o fenômeno chamado de ruptura progressiva como um processo sucessivo da formação da superfície de ruptura através da redistribuição de tensões e da perda da resistência ao cisalhamento do material.

\subsubsection{Modos de Ruptura}

Segundo PATTON e DEERE (1971), conforme a geometria da ruptura e a altura dos taludes de mineração a céu aberto, e adicionalmente, incluindo o grau de fraturamento do maciço rochoso, as rupturas podem abranger uma determinada escala. Estas rupturas foram divididas em três tipos, conforme se apresenta na FIGURA 2.5.

(a) Rupturas locais (Tipo I), são aquelas rupturas que ocorrem em nível de bancada, controladas por juntas e falhas dessas mesmas magnitudes.

(b) Rupturas de maior escala (Tipo II), são aquelas controladas por descontinuidades persistentes, tais como sistemas de juntas combinadas com falhas. Este tipo de ruptura envolve um grande volume de massa rochosa. Estas podem ocorrer de acordo com a configuração geométrica das descontinuidades pré-existentes em relação ao talude, gerando desta forma rupturas do tipo planar ou cunha.

(c) Rupturas em rochas Fraturadas (Tipo III), são aquelas associadas ao alto fraturamento, típico de rochas brandas e alteradas que influenciam a estabilidade devido a sua baixa resistência. Este tipo de ruptura pode envolver várias bancadas ou até o talude global. 


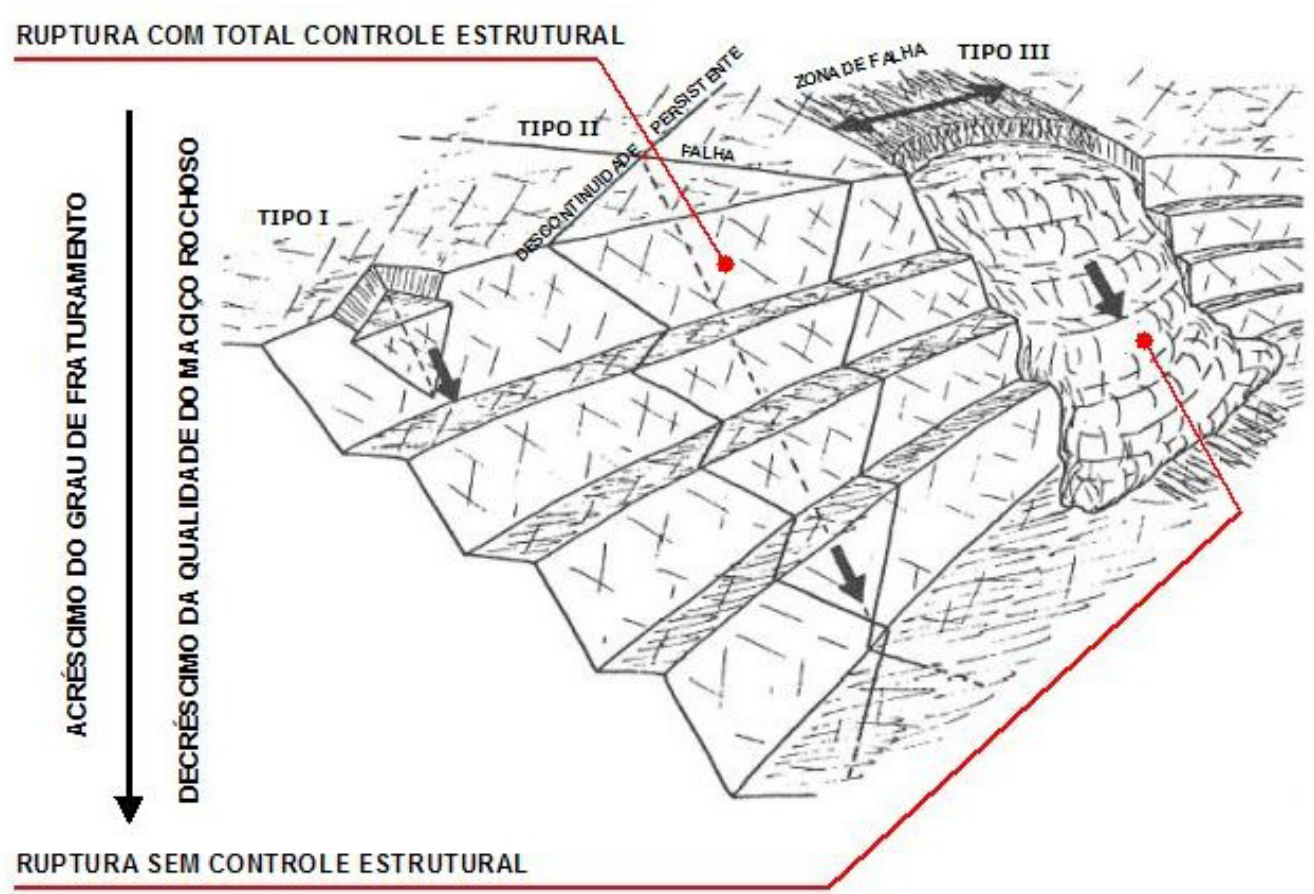

FIGURA 2.5 Tipos de rupturas em taludes de mineração a céu aberto (Mod. de PATTON e DEERE, 1971).

DE FREITAS e WATTERS (1973) e GOODMAN e BRAY (1976) descreveram a ruptura por tombamento, em que ocorre o tombamento de colunas de rocha formadas por descontinuidades com mergulho quase normal ao talude. COATES (1977) fez uma classificação dos modos de ruptura com base nos critérios geométricos, e estas são: ruptura planar, ruptura em cunha, ruptura circular e ruptura por fluência de blocos (tombamento), que é usada até hoje com essas mesmas denominações. HOEK e BRAY (1981) sintetizam no seu texto "Rock Slope Engineering", a maior parte de trabalhos até então publicados, estabelecendo ou reafirmando os critérios geométricos e cinemáticos que determinam a ocorrência de rupturas em taludes. Segundo os autores nos taludes podem ocorrer quatro modos de rupturas: ruptura circular, ruptura planar, em cunha e por tombamento, além disso, comentam que existem rupturas complexas.

HUDSON e HARRISON (1997) e HOEK et al. (2000b) classificaram a instabilidade de taludes em dois grupos: o primeiro, quando o maciço rochoso se apresenta como um meio equivalente contínuo (maciço rochoso fraturado, sem controle estrutural), originando o modo de ruptura circular, e o segundo quando o maciço rochoso se apresenta como um meio descontínuo (presença de descontinuidades, com controle estrutural) originando rupturas governadas pelas descontinuidades, tais como: rupturas planares, em cunha e por tombamento. 
SJÖBERG (1999), a partir de uma compilação de vários trabalhos referentes a rupturas em taludes altos (300 m a $500 \mathrm{~m}$ ) em minas a céu aberto, mostrou que os modos de ruptura mais freqüentes são as rupturas circulares (sem controle estrutural) e as rupturas por tombamento flexural de grandes dimensões, conforme a FIGURA 2.6. Muitas destas rupturas registradas por aquele autor tiveram deslocamentos lentos e progressivos.

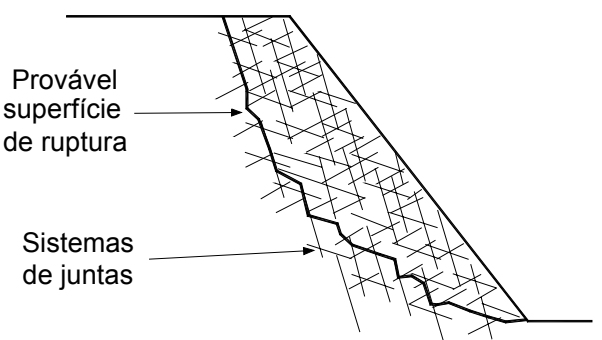

A) Rupturas circulares e não circulares em maciço rochoso altamente fraturado

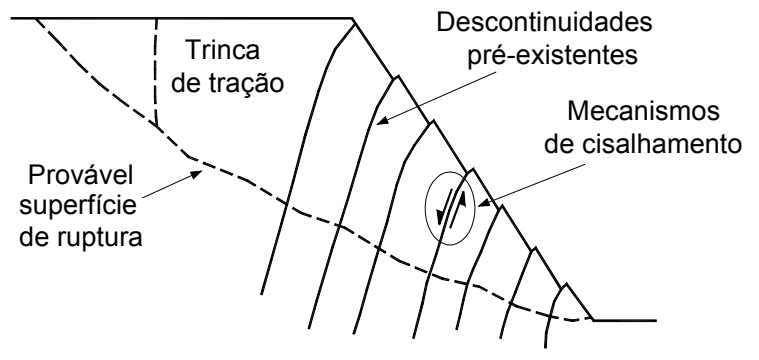

B) Rupturas por tombamento de grandes dimensões

FIGURA 2.6 Modos de ruptura mais freqüentes em taludes altos (Mod. de SJÖBERG, 1999).

\section{Rupturas sem controle estrutural}

Dentro deste grupo encontram-se as rupturas circulares e não circulares. Nestas rupturas não há nenhum padrão estrutural definido ou orientações críticas das descontinuidades ou planos de fraqueza. Estas rupturas são típicas de maciços de solos. Segundo HOEK e BRAY (1981), a ruptura circular também pode ocorrer em taludes de rocha, onde não há fortes condicionantes estruturais (padrão estrutural não definido), assim como em maciços rochosos altamente fraturados sem predominância na orientação das descontinuidades. Desta forma, as partículas individuais da massa rochosa (bloco unitário) são pequenas comparadas à altura do talude. SJÖBERG (1999) abordou o efeito escala a ser considerado para a ocorrência de rupturas do tipo circular, ressaltando a condição de que o bloco unitário da massa rochosa seria muito pequeno quando comparado à dimensão do talude.

O termo circular é usado de modo amplo, englobando modos rotacionais, sem restrição rigorosa da forma da superfície. Segundo BISHOP (1967), superfícies de rupturas não circulares poderiam ser mais realistas. Assim, para rochas em que a heterogeneidade e a anisotropia intrínsecas, resultantes do fraturamento intenso, ocorram em direções preferenciais, a ruptura não circular seria a mais representativa. Segundo CELESTINO e DUNCAN (1980), tomando como exemplo a barragem Waco, Estados Unidos, a forma da 
superfície crítica pode ser do tipo não-circular para solos e rochas que sejam anisotrópicos em relação à resistência ao cisalhamento. A superfície crítica nestes casos pode ser localizada usando procedimentos de busca descritos por aqueles autores.

Como exemplo de ruptura de grande porte em mineração a céu aberto, apresentase na FIGURA 2.7 uma ruptura com aproximadamente $350 \mathrm{~m}$ de altura num talude global de aproximadamente $600 \mathrm{~m}$. O maciço rochoso envolvido nesta ruptura é alterado e fraturado. Esta ruptura ocorreu sem controle estrutural, sendo do tipo circular. A superfície de ruptura, segundo HOEK et al. (2000b), provavelmente passa através do maciço rochoso fraturado e alterado, enfraquecido pela presença de juntas, ou que estaria governada por algum tipo de controle estrutural. No entanto, esta instabilidade pode também se dever às tensões induzidas (redução da resistência), atuação d'água subterrânea, a danos induzidos oriundos de desmontes.

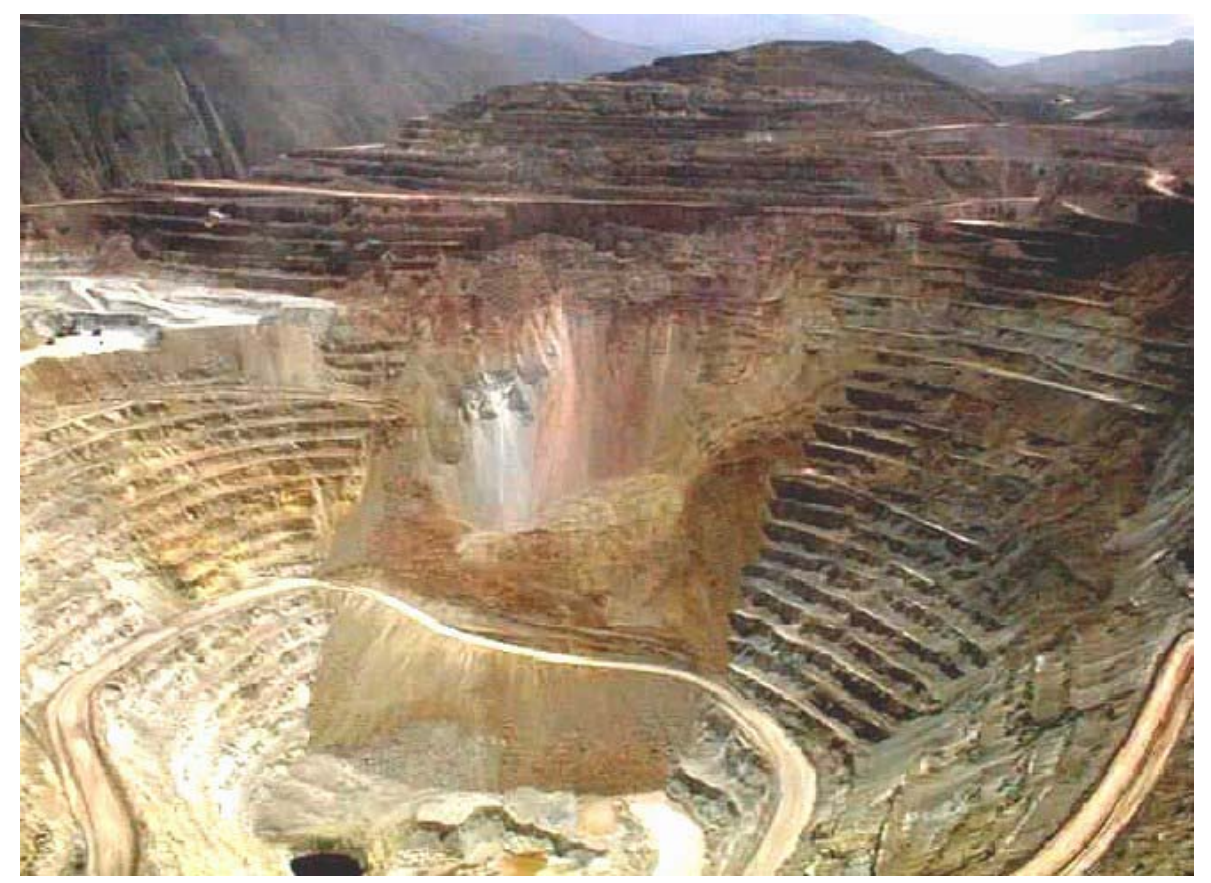

FIGURA 2.7 Exemplo de ruptura em taludes altos de mineração a céu aberto (HOEK et al., 2000b).

\section{Rupturas com controle estrutural}

Estas rupturas podem ser estudadas através de análise estereográfica (condições cinemáticas), definida pela orientação das descontinuidades em relação à geometria do talude. As rupturas planares, em cunha e por tombamento se encontram neste grupo. 
A ruptura planar ou em cunha em taludes altos que envolvam grande volume do maciço rochoso, só pode ocorrer com a presença de descontinuidades persistentes, tais como as falhas medianas e maiores, além de obedeceram às condições cinemáticas. $\mathrm{Na}$ FIGURA 2.8 são apresentados dois exemplos de rupturas governadas por estas descontinuidades persistentes, onde a ruptura envolve várias bancadas. Por outro lado, isto não é uma condição, pois há casos onde a superfície de ruptura planar ou em cunha é formada pela união de várias descontinuidades menores. Conforme a literatura, as rupturas planares e em cunha são mais comuns em nível de bancadas, onde estão governadas por descontinuidades menores, sejam falhas ou juntas.
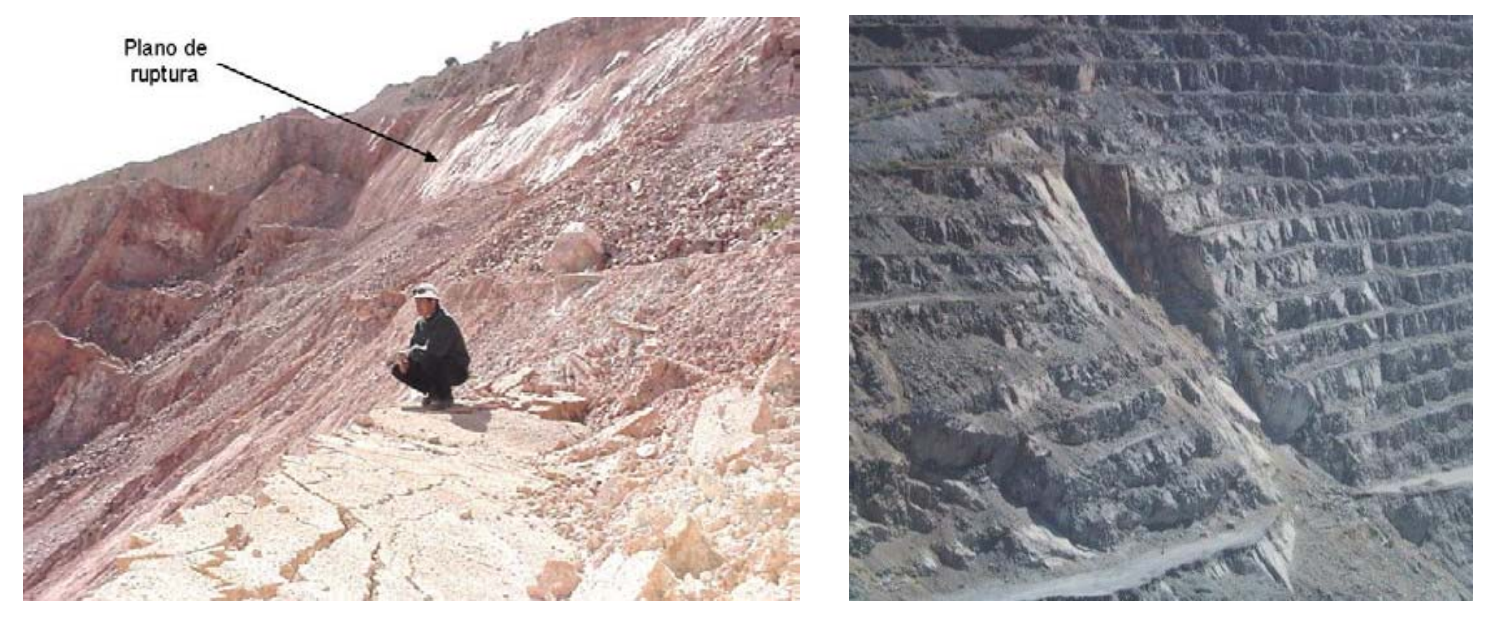

FIGURA 2.8 Rupturas com controle estrutural: (a) ruptura planar e (b) ruptura em cunha.

Por sua vez, as rupturas por tombamento foram observadas numa serie de massas rochosas. Este tipo de ruptura pode ocorrer tanto em taludes naturais como em taludes de mineração a céu aberto, o qual foi estudado por vários pesquisadores (DE FREITAS e WATTERS, 1973; GOODMAN e BRAY, 1976; COATES, 1977; WYLLIE, 1980; HOEK e BROWN, 1981; CRUDEN, 1989). Segundo estes autores, o tombamento ocorre quando a direção das descontinuidades é sub-paralela ao talude, em aproximadamente $\pm 30^{\circ}$ (GOODMAN, 1989; CRUDEN, 1989) e com mergulho quase normal em relação ao mesmo.

SJÖBERG (1999) descreve rupturas por tombamento flexural de grandes dimensões. Segundo CALL et al. (2000), descontinuidades persistentes (falhas medianas) formadoras da ruptura por tombamento diminuem a rigidez do maciço rochoso, formando, assim, blocos discretos. 


\subsubsection{Mecanismos de Ruptura}

A literatura mostra casos em que os mecanismos de ruptura foram estudados via modelos físicos bidimensionais, simulando maciços rochosos (blocos discretos) fraturados com até três sistemas de juntas (BARTON, 1972, 1974 e STACEY, 1973, apud SJÖBERG, 1999). STACEY (1973) fez ensaios em centrífuga (ensaios bidimensionais e tridimensionais), simulando taludes fraturados. BARTON $(1972,1974)$ fez um modelo físico de talude de grande porte simulando um modelo de talude em rocha (40000 blocos discretos). Conforme os resultados dos ensaios de STACEY (1973) e BARTON (1972, 1974), a instabilidade ocorreu só por deslizamentos ao longo de juntas pré-existentes que passam pelo pé do talude. BARTON $(1972,1974)$ mostra que a ocorrência da deformação na crista do talude é decorrente da escavação. Cabe salientar que, a partir dos ensaios físicos feitos pelos autores supramencionados, foi revelado que os mecanismos de ruptura são de natureza progressiva.

As rupturas por tombamento e do tipo circular foram pesquisadas através de ensaios de centrífuga por ADHIKARY (1995). Os resultados daquele autor mostraram que para modelos homogêneos, como era de esperar, ocorreu a ruptura circular. A superfície de ruptura originou-se no pé do talude, avançando progressivamente pelo interior do talude até interceptar a sua crista num ângulo quase reto. Para taludes com descontinuidades paralelas à face e com mergulho para o talude, ocorreu o tombamento flexural. A instabilidade inicia-se com a rotação das colunas formadas entre as descontinuidades, seguida pela ruptura da base das mesmas colunas, assim formando a superfície de ruptura, que iniciou-se no pé e propagou-se pelo interior do talude.

Por outro lado, MÜLLER (1966) concluiu que as rupturas em taludes de rocha envolveriam, no seu começo, cisalhamento ao longo de descontinuidades pré-existentes e que a ruptura da rocha intacta (ponte rochosa) poderia criar um mecanismo progressivo de ruptura, condicionado também pela dilatância no trecho da junta pré-existente. Tal mecanismo parece aceitável e, desta forma, a superfície de ruptura, considerando o ponto de vista daquele autor, estaria composta principalmente por descontinuidades préexistentes com porções da rocha intacta.

De acordo com COLLIN (apud SKEMPTON, 1949), TERZAGHI (1944), ROMANI et al. (1972) e CHOWDHURY (1978), citados por SJÖBERG (1999), a ruptura começa na crista do talude, baseado no fato de que as trincas de caráter tensional desenvolvem-se primariamente na zona da crista, sendo esta zona ativa e livre para movimentar-se. Uma outra alternativa seria que a ruptura se inicia no pé do talude, onde é encontrada alta 
concentração de tensões de cisalhamento (VEDER, 1981; ZÁRUBA e MENCL, 1982, apud SJÖBERG, 1999). Segundo BISHOP (1967), a superfície de ruptura avança progressivamente do pé do talude para a sua crista. Por sua vez, HARR (1977) apud SJÖBERG (1999) concluiu que a ruptura começa num ponto qualquer que não seja necessariamente o pé do talude, o que se deve ao fato de que, em mineração a céu aberto conforme o avanço da escavação, o pé do talude geral toma uma nova localização, o que leva a pensar que rupturas sucessivas comecem no pé.

A afirmação de BISHOP (1967), de alguma forma pode estar sustentada pelos estudos de DODD e ANDERSON (1971) e SJÖBERG (1999) entre outros pesquisadores. Estes autores a partir de análises numéricas concluíram que há concentração de tensões compressivas e de cisalhamento no pé do talude, as quais favorecem as instabilidades.

Com base, nos estudos de modelos físicos e de modelagem numérica, é muito provável que a superfície de ruptura se inicie no pé do talude, tanto em rupturas por tombamento como para as rupturas circulares e rupturas complexas. Além disso, como já foi mencionada, a superfície de ruptura em maciços rochosos é provável que não seja uma simples superfície de cisalhamento, estando ela composta pela união de várias descontinuidades envolvendo rupturas da rocha intacta entre as descontinuidades.

Por outro lado, os mecanismos de rupturas foram estudados através de análises numéricas, onde se pesquisou o comportamento dos taludes. Vários exemplos de aplicação da modelagem numérica a estudos de taludes podem ser encontrados na literatura (PRITCHARD e SAVIGNY, 1990, 1991; MARTIN, 1990; ORR et al., 1991; BOARD et al., 1996; SJÖBERG, 1999, 2000; NICHOL et al., 2002). O comum destes casos é que o comportamento do talude seja duplicado ou reconstruído através da modelagem numérica. Para isto os diferentes parâmetros de entrada podem ser variados, em coerência com os observados em campo, até conseguir uma boa representatividade da geometria da ruptura observada.

CALL et al. (2000) discutiram o mecanismo de ruptura por tombamento, o qual está governado por descontinuidades persistentes (falhas medianas) de alto ângulo e paralelas ao talude, conforme visto na FIGURA 2.9. Segundo aquele autor as descontinuidades persistentes diminuem a rigidez do maciço rochoso, assim, formando blocos discretos. Uma característica que ele apresenta, é que o material do pé do talude tem baixa qualidade geotécnica em relação ao resto do talude. A partir de tal característica podem apresentar-se rupturas com comportamento de natureza regressiva de grandes dimensões. Para os autores, os deslocamentos se iniciam no pé do talude, fato 
demonstrado pelo avanço da escavação na região do pé do talude (remoção da rocha de baixa qualidade geotécnica). Depois lá o deslocamento do talude global (parte localizada acima da rocha fraca), isto devido ao rearranjo sucessivo dos blocos discretos. Nestas características, segundo estes autores, o talude é conduzido para uma situação estável (que pode ser temporária) após um certo deslocamento.

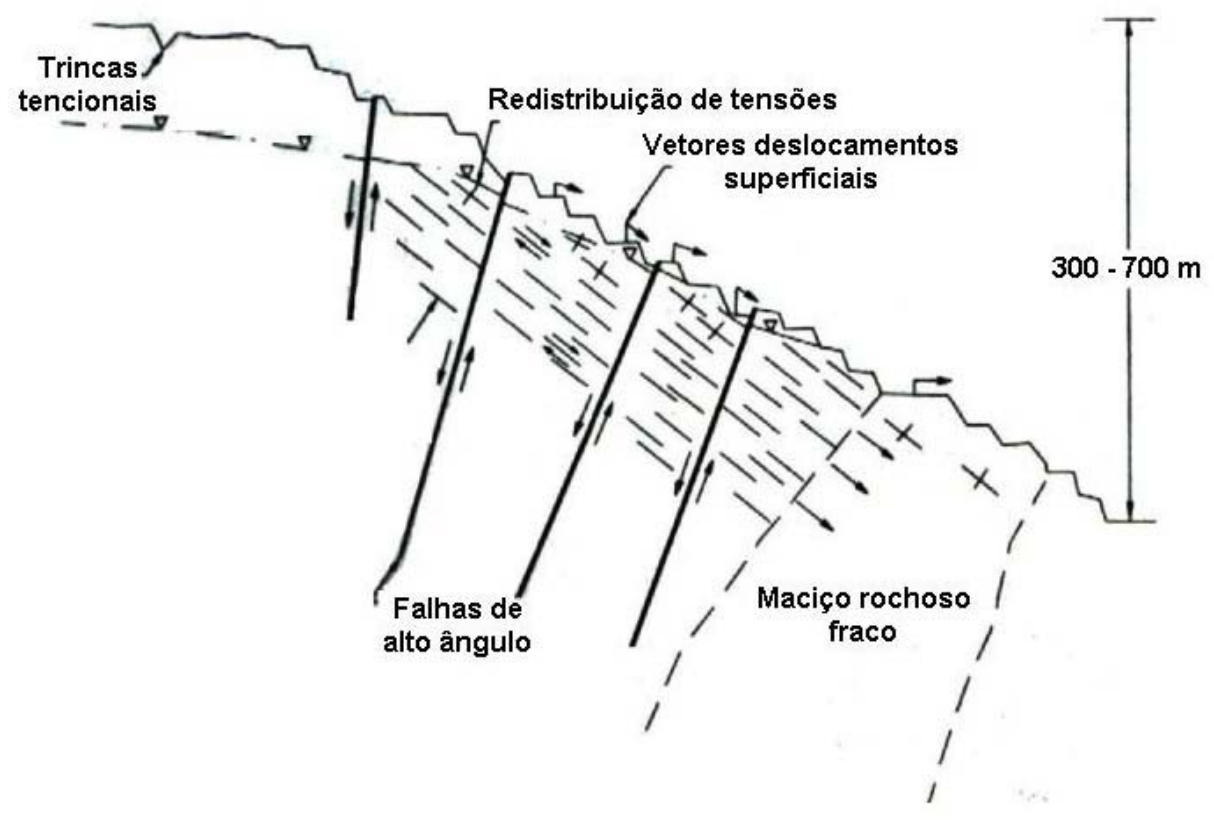

FIGURA 2.9 Ruptura por tombamento de grandes dimensões (CALL et al. 2000).

SJÖBERG $(1999,2000)$ estudou a ruptura circular para taludes altos de rocha através do método de diferenças finitas (FLAC), e usou o modelo constitutivo elastoplástico de Mohr-Coulomb. Considerou como dados de entrada: a resistência ao cisalhamento da rocha (coesão e atrito), as condições das tensões iniciais e do nível d'água subterrâneo. Os parâmetros de entrada foram variados e escolhidos para obter a ruptura e, assim, estudar as condições em que se produzem as mesmas. Segundo aquele autor, a ruptura ocorre em várias fases, conforme apresentado na FIGURA 2.10, afirmando também que grandes deslocamentos ocorrem antes que a superfície de ruptura se desenvolva completamente. 
1

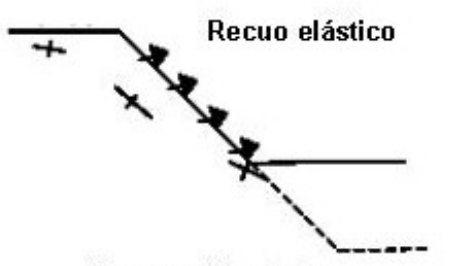

Nova sequiência de escavação

IV

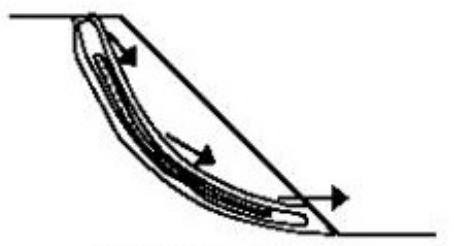

Superficie de ruptura, completamente desenvolvida
II

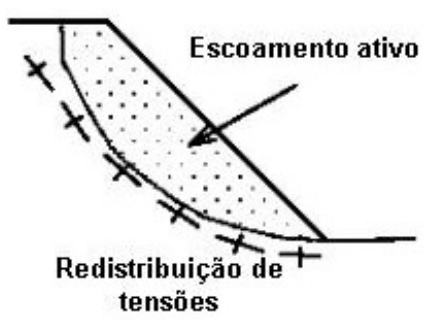

V

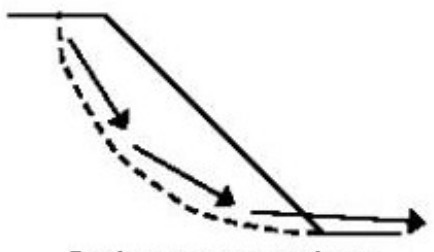

Deslocamentos maiores, começo no pé do talude
III

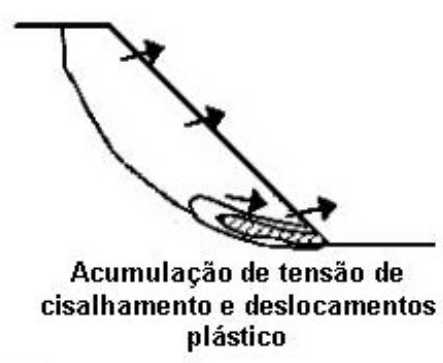

VI

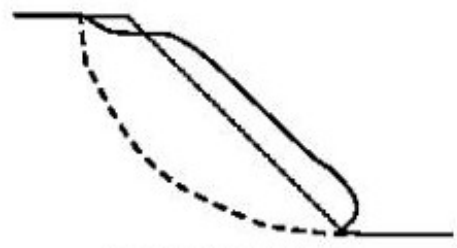

Secção de talude deformado

FIGURA 2.10 Mecanismos de rupturas: ruptura circular (SJÖBERG, 1999).

Existem vários trabalhos que analisam a ruptura por tombamento de grandes dimensões e seus respectivos mecanismos, tanto em observações de campo, como na modelagem numérica. SJÖBERG $(1999,2000)$ simulou a ruptura por tombamento flexural através do método dos elementos distintos (UDEC) e por diferenças finitas (FLAC). Para aquele autor, além das condições geométricas básicas para a ocorrência da ruptura por tombamento, o maciço rochoso deve ter capacidade de deformação compatível com aquele mecanismo. Ele também deve possuir baixa resistência à tração para facilitar o dobramento e a conseqüente ruptura na base das colunas formadas. O tombamento ocorre em etapas como é mostrado na FIGURA 2.11. Esta ruptura estaria governada inicialmente por mecanismos de cisalhamento ao longo das descontinuidades de ângulo elevado; o cisalhamento começaria no pé do talude e teria uma propagação até a crista, acompanhado da redistribuição de tensões. Na seqüência, ter-se-ia o dobramento das colunas de rocha, inicialmente no pé do talude, e este seria seguido por uma ruptura de tração na base da coluna. Finalmente, a ruptura se propagaria até a crista e a superfície de ruptura se desenvolveria. 


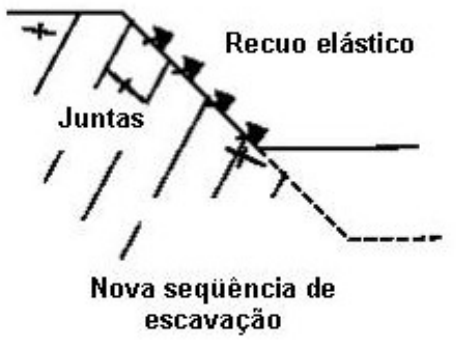

IV

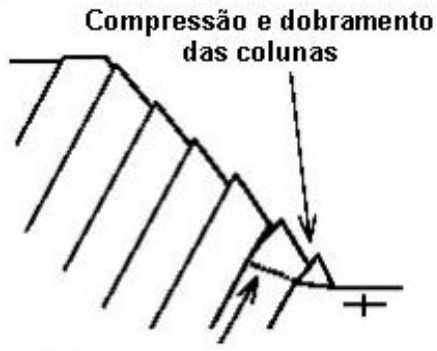

Dobramento com começo no pé do talude
II

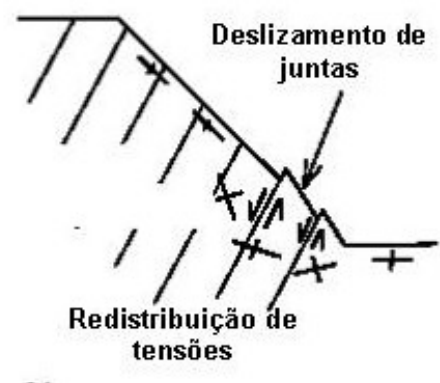

V

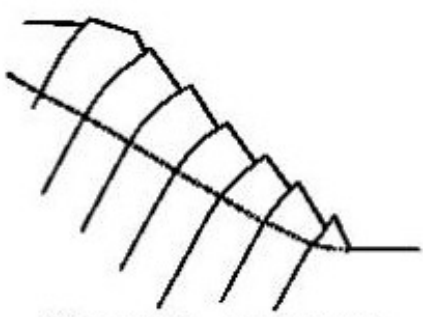

Dobramento e ruptura por tração na base das colunas
III

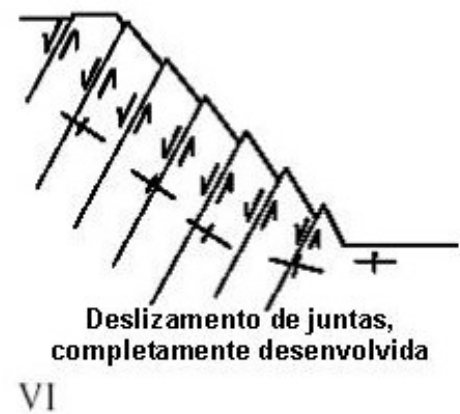

Deslizamento ao longo da

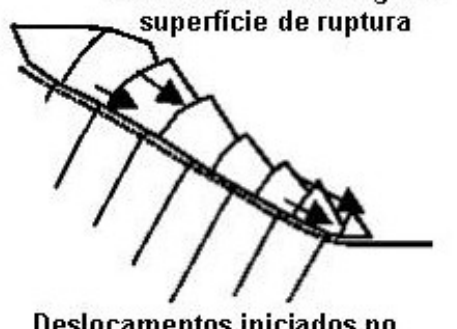

Deslocamentos iniciados no pé do Talude

FIGURA 2.11 Mecanismos de ruptura: ruptura por tombamento (SJÖBERG, 1999).

$\mathrm{Na}$ ruptura por tombamento, a superfície de ruptura, em alguns casos, desenvolveu-se quase paralela à face do talude; em outros casos, pode ser curva, dependendo basicamente da distribuição espacial das descontinuidades no talude global (PRITCHARD e SAVIGNY, 1990). Observações similares foram feitas por ORR et al. (1991), relatando que as rupturas por tombamento originam uma forma final amplamente circular, tanto em planta como em perfil. Assim, descrevem estas rupturas como pseudocirculares.

\subsection{Monitoramento Geotécnico de Taludes}

Quando a geometria do maciço rochoso é modificada, ocorre uma redistribuição de tensões ao longo da borda do vazio criado, gerando no caso de taludes uma região de alívio de tensões (na face) e uma região de acúmulo de tensões compressivas e de cisalhamento (no pé), conforme a FIGURA 2.2. Este fenômeno gera algumas modificações do maciço rochoso no seu conjunto. Assim estas modificações podem estar manifestadas pela deformação do maciço rochoso no seu conjunto e mudanças do lençol freático. A deformação do maciço rochoso fisicamente pode estar manifestada pela aparição de trincas de tração na crista do talude (detectadas por observações de campo), deslocamentos no interior do talude (detectadas por monitoramento), embarrigamentos na 
face do talude (que podem ser detectadas através de monitoramento), entre outras. Estas modificações do maciço rochoso decorrentes da escavação podem ser detectadas através da instrumentação geotécnica.

O monitoramento geotécnico tem como objetivos: (1) manter em condições seguras o pessoal, equipamentos e a operação da lavra, (2) prever de forma provisória a instabilidade para tomar planos de contingência, (3) fornecer informação geotécnica relativa ao comportamento do talude para que ajude no entendimento do eventual mecanismo de ruptura (CALL, 1982; CALL e SAVELY, 1990), ao mesmo passo, que permite definir áreas de maior risco (excesso de deslocamentos).

Na FIGURA 2.12 apresenta-se graficamente a instrumentação geotécnica a ser usada para diferentes fins, como medir os: (1) deslocamentos superficiais através de prismas (estações refletoras) e extensômetros de cabo, (2) deslocamentos sub-superficiais através de inclinômetros, os quais são usados para localizar a profundidade da superfície de ruptura com deslocamentos horizontais e, (3) Variação do lençol freático através de piezômetros.

Redes de prismas ou estações refletoras, conforme a FIGURA 2.12, são colocadas no talude, sendo este o método mais comum para monitorar os deslocamentos superficiais. As medições são feitas de um ponto base usando um instrumento chamado de estação total que mede distâncias e ângulos. Esta base deve estar localizada sobre terreno estável, ao mesmo tempo em que deve estar suficientemente perto da crista do talude para que os prismas possam ser visualizados. Por outro lado, pontos de referência são necessários com a finalidade de monitorar a estabilidade da estação base.

Os extensômetros de cabo são instrumentos complementares para o monitoramento de deslocamentos relativos superficiais. Estes instrumentos consistem de um cabo tencionado, localizado perpendicular às trincas de tração. Geralmente este instrumento é usado na crista do talude. Uma desvantagem deste instrumento é que ele não fornece um monitoramento em longo prazo. Adicionalmente, o mapeamento visual de trincas de tração é um método simples que providencia alguma informação sobre a extensão de uma área instável.

Através dos furos de sondagens instrumentados com inclinômetro pode ser medida a deflexão angular ao longo de seu comprimento. Desta forma, determinam-se os deslocamentos horizontais em diferentes direções. Conseqüentemente, e conforme apresentado na FIGURA 2.12, o inclinômetro permite conhecer a localização da superfície de ruptura num talude que se encontra em movimento. 


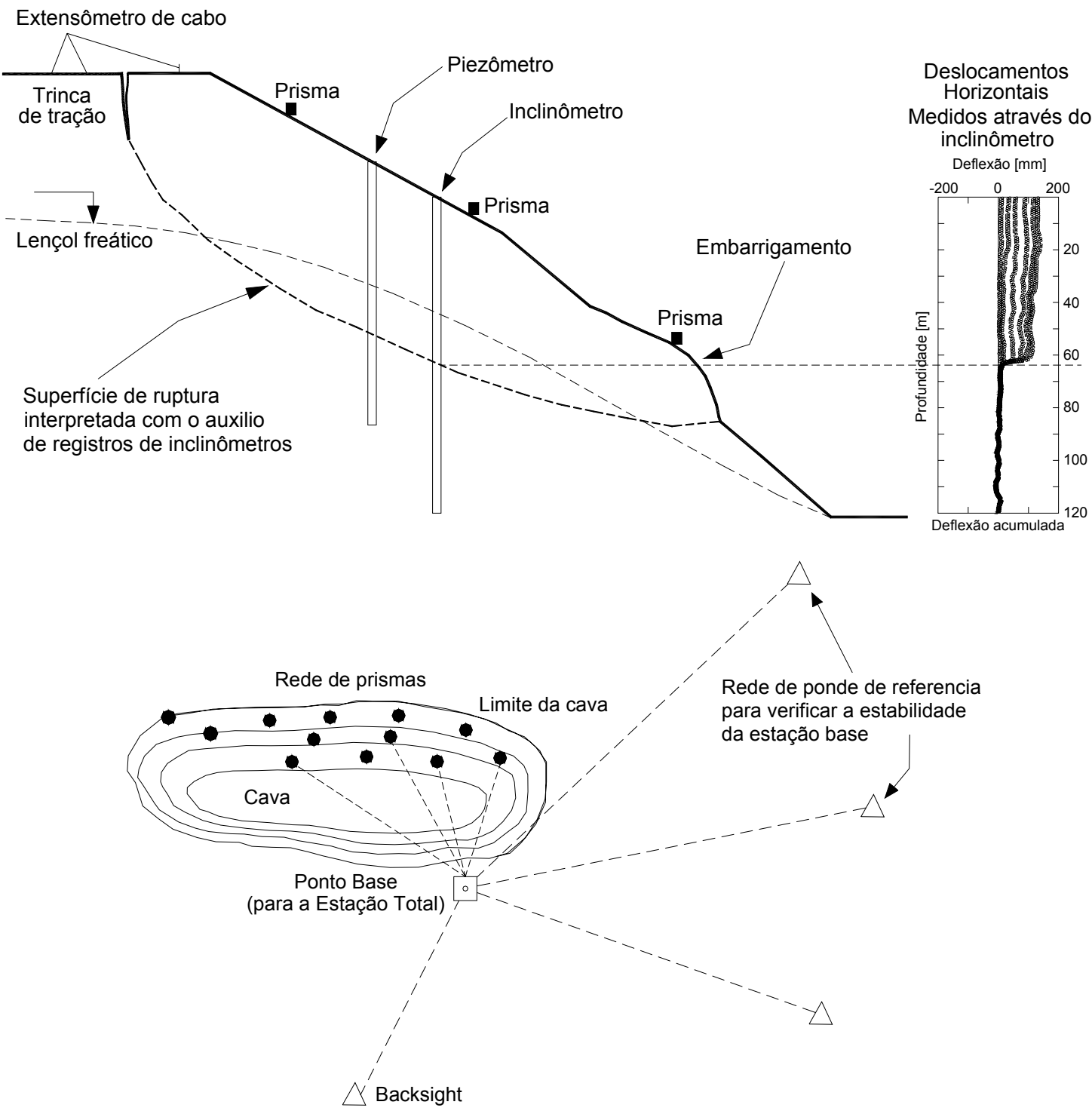

FIGURA 2.12 Instrumentação geotécnica para o monitoramento de taludes altos em mineração a céu aberto.

A variação do nível do lençol freático depende, entre outros fatores, das mudanças da geometria do talude. Esta variação pode ser monitorada através dos piezômetros, conforme o esquema da FIGURA 2.12. Os piezômetros mais comuns e por seu baixo custo usados em mineração a céu aberto são os piezômetros de tubo aberto. Estes são furos de sondagens instrumentados com piezômetro (tubos com furos para permitir a passagem d'água em uma região denominada bulbo). O sistema de medição se faz através de um sensor de indicador de nível d'água. O monitoramento do lençol freático é feito com a finalidade de conhecer a distribuição da pressão d'água, ao mesmo tempo que essa informação junto ao padrão de fluxo d'água e as propriedades hidráulicas do maciço 
rochoso podem ser usadas para otimizar os planos de contingência em relação à estabilidade de taludes, como o projeto de drenagem.

\subsection{Comportamento de Taludes}

Segundo a literatura, em taludes de mineração a céu aberto, mesmo que tenham comportamento instável, a produção de minério não deve ser prejudicada. Assim, as conseqüências de uma provável ruptura (colapso) devem ser mínimas. Para isto, com o auxilio da instrumentação geotécnica deve prever-se provisoriamente a instabilidade e a velocidade de ruptura, com a finalidade de implementar planos de contingência. Como exemplo de previsão de rupturas de taludes de mineração a céu aberto pode-se citar o caso reportado por KENNEDY e NIERMEYER (1970) da mina Chuquicamata, Chile, acontecido em 1969, onde foram usados dados obtidos pelo monitoramento de deslocamentos em longo prazo, a partir do qual foi prevista a ruptura através do gráfico deslocamento acumulado versus tempo.

Algum tipo de instabilidade pode-se esperar no maciço rochoso decorrente das escavações. Estas instabilidades podem variar desde pequenas até grandes massas de rocha. Segundo SULLIVAN (1993), os deslocamentos horizontais de taludes a céu aberto, podem ser divididos em quatro fases em função do tipo de deslocamentos:

1) Deslocamentos elásticos: são devidos basicamente à reação do maciço rochoso ao processo de descarregamento correspondente à escavação, e são função das tensões e do módulo de elasticidade do maciço rochoso. Estes deslocamentos podem variar de poucos milímetros até metros, dependendo da profundidade da escavação;

2) Deslocamentos por fluência: são deslocamentos dependentes do tempo e que acontecem em alguns maciços de solos e rochas;

3) Deslocamentos decorrentes do fraturamento e deslizamento: estes são considerados como conseqüentes de ruptura, e representam um dos primeiros estágios do colapso, como a aparição e abertura de trincas de tração na crista do talude. Neste contexto o termo ruptura deve-se aplicar quando as solicitações atingem a resistência do material;

4) Deslocamentos por colapso: o colapso pode variar desde o deslizamento de um bloco individual de rocha até a ruptura de grande porte, colapso do talude global. Como exemplo pode citar-se a ruptura apresentada na FIGURA 2.7.

As características de deslocamento versus tempo de rupturas em taludes altos foram descritas por ZAVODNI e BROADBENT (1978) e BROADBENT e ZAVODNI (1982). 
Estes autores concluíram que quase todas as rupturas de grande porte ocorreram gradualmente, excluindo as rupturas iniciadas por eventos sísmicos. Estes mesmos autores definiram duas fases para rupturas de grande porte: fase progressiva e fase regressiva, dependendo da tendência de condição instável ou estável. Por outro lado, SJÖBERG (1999) utiliza a terminologia de fase instável para descrever a fase progressiva e de fase estável para descrever a fase regressiva, com a finalidade de evitar confusão com o termo de ruptura progressiva. No presente trabalho se utilizará o termo de ruptura progressiva conforme foi definida por CHOWDHURY (1978), como o processo sucessivo da formação da superfície de ruptura. Os termos de fase progressiva e fase regressiva serão usados conforme foram apresentados na literatura (ZAVODNI e BROADBENT, 1978; CALL et al., 1993; ZAVODNI, 2000). A fase regressiva apresenta ciclos de deslocamentos desacelerados, por sua vez a fase progressiva apresenta deslocamentos a uma taxa acelerada, FIGURA 2.13.

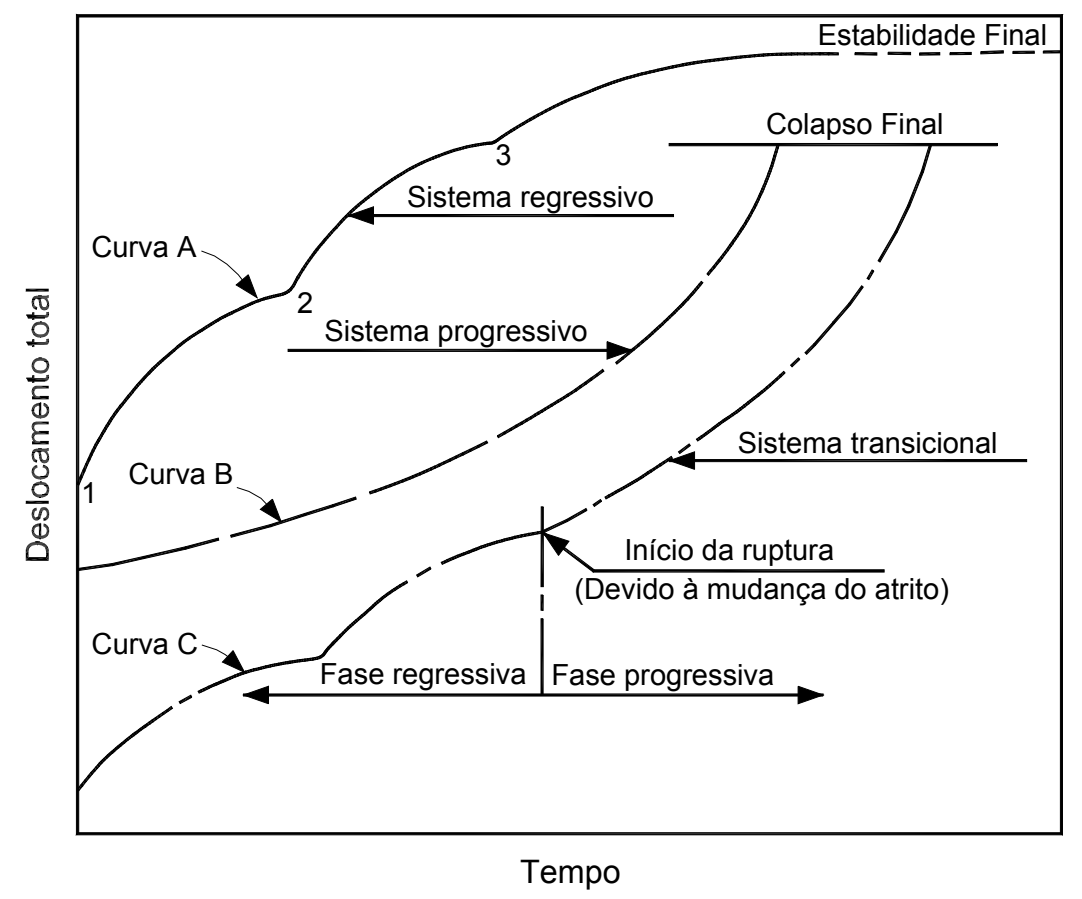

FIGURA 2.13 Fase de ruptura progressiva e ruptura regressiva (BROADBENT e ZAVODNI, 1982).

\subsubsection{Fase Regressiva}

A fase regressiva baseada nos deslocamentos é tipificada pela curva A da FIGURA 2.13. A característica que descreve esta curva como regressiva é a desaceleração dos deslocamentos de cada ciclo entre os pontos 1, 2 e 3 . Segundo BROADBENT e KO 
(1972), os pontos 1, 2 e 3 descrevem o início de aceleração. Acredita-se que os ciclos são iniciados quando as forças mobilizantes excedem temporalmente as forças resistentes, e o talude esteja com um valor de fator de segurança menor que um. A velocidade de movimento diminuirá quando as forças externas forem reduzidas. Estas forças externas geralmente são relacionadas ao desmonte, aos eventos sísmicos, à precipitação pluvial e à pressão d'água subterrânea.

\subsubsection{Fase Progressiva}

A fase progressiva baseada nos deslocamentos é tipificada pela curva B da FIGURA 2.13 a qual se manifesta como uma curva exponencial positiva no gráfico deslocamento acumulado versus tempo. Segundo ZAVODNI e BROADBENT (1980), em rupturas de grande porte, o período de tempo no qual se dão os deslocamentos progressivos são relativamente curtos, 4 a 45 dias. Segundo estes autores, parece que o período destes deslocamentos está um pouco relacionado ao volume da ruptura. Conforme a literatura, as rupturas que apresentam comportamento como da fase progressiva são governadas por condições estruturais (BROADBENT e ZAVODNI, 1982 e ZAVODNI, 2000).

Segundo CALDER e BLACKWELL (1980), as rupturas por tombamento ou rupturas em cunhas induzidas teriam um comportamento conforme a curva C. Estes tipos de ruptura têm características altamente variadas. Podem ser regressivas particularmente no caso das rupturas em cunha induzidas, ou progressivas para as rupturas por tombamento. Assim, segundo estes autores, este comportamento merece mais estudo e análise.

BROADBENT e KO (1972), ZAVODNI e BROADBENT (1978), BROADBENT e ZAVODNI (1982) e RYAN e CALL (1992) têm notado que os deslocamentos ocorrem em ciclos bem definidos com tempos de duração variada, conforme apresentado na FIGURA 2.13. Estes ciclos podem ser atribuídos a fatores externos que perturbam o sistema tais como as chuvas, forças devidas à aceleração sísmica, mudanças da geometria. Segundo estes autores, parece ser mais difícil prever quantitativamente a duração e ocorrência de ciclos dos deslocamentos, que descrever e prever o comportamento de longo prazo do talude. 


\section{Capítulo 3}

\section{Ruptura Progressiva em Rocha}

\subsection{Introdução}

A resistência da rocha intacta foi estudada através de ensaios de compressão simples e triaxial por vários pesquisadores, como HOEK e BIENIAWSKI (1965), BRACE et al. (1966), BIENIAWSKI (1967), WAWERSIK e FAIRHURST (1970) entre outros. Estes pesquisadores usaram corpos de prova com relação comprimento/diâmetro de 2 a 3 , sendo o diâmetro mínimo igual a $54 \mathrm{~mm}$. O carregamento foi aplicado com velocidades entre 0,5 e $1 \mathrm{MPa} / \mathrm{s}$. Segundo as recomendações da ISRM (1981) foram registradas tanto a deformação axial quanto a deformação lateral do corpo de prova durante os ensaios de compressão simples e triaxial. Segundo COOK (1970) essa deformação volumétrica de um corpo de prova medida através de extensômetros elétricos de resistência na superfície do mesmo é uma propriedade volumétrica importante e não apenas um fenômeno superficial. Os pesquisadores supramencionados têm salientado que nesse caso o processo de ruptura é dominado pelo crescimento de micro-fissuras paralelas à direção da tensão máxima aplicada. Este mecanismo foi observado em corpos de prova sólidos e cilíndricos em diferentes tipos de rochas (JAEGER e COOK, 1969).

HOLZHAUSEN e JOHNSON (1979) verificaram que o corpo de prova sob carregamento uniaxial sofre deformação permanente antes de romper. Esta deformação consiste primariamente no crescimento de micro-fissuras intergranulares e transgranulares em direções aproximadamente paralelas à direção de carregamento uniaxial, conforme é ilustrado na FIGURA 3.1. Segundo aqueles autores, o crescimento das microfissuras se inicia no ponto correspondente ao término da porção linear da curva tensãodeformação, axial, na qual, se inicia a dilatância. 


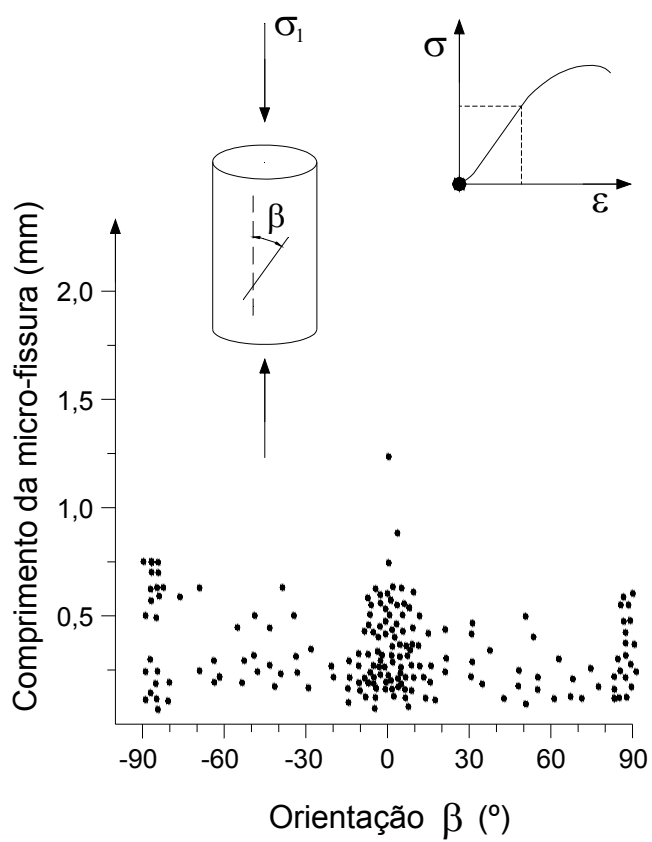

(a)

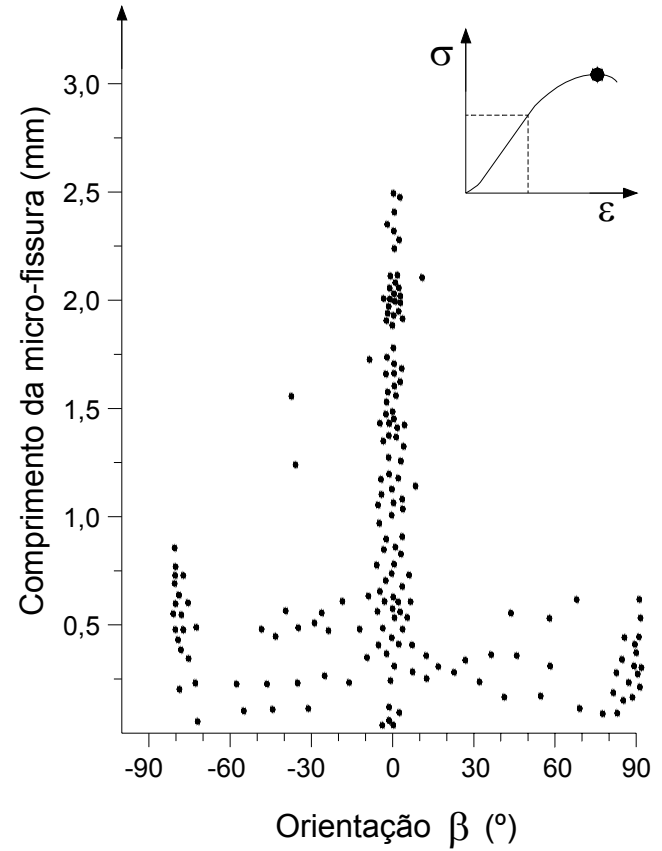

(b)

FIGURA 3.1 Comparação do crescimento das micro-fissuras versus a orientação das mesmas: (a) Amostra não carregada. (b) amostra carregada uniformemente até uma tensão próxima da tensão de pico (Mod. de HOLZHAUSEN e JOHNSON, 1979).

\subsection{Processos de Ruptura em Rochas Frágeis}

BIENIAWSKI (1967) analisou a ruptura frágil em rocha a partir da evolução da curva tensão-deformação axial, tensão-deformação radial e tensão-deformação volumétrica. Assim, sugeriu que o caminho efetivo para o estudo de rochas fraturadas seja a determinação completa da curva característica tensão-deformação, sendo possível, segundo ele, distinguir cinco regiões na curva tensão-deformação: fechamento de microfissuras, trecho linear, propagação estável, propagação instável e a região pós-pico. MARTIN (1993) e MARTIN e CHANDLER (1994) distinguem três níveis de tensão, conforme a FIGURA 3.2, associados ao desenvolvimento de micro-fissuras, a saber:

(1) $\sigma_{c i}$ - tensão de início de micro-fissuras (tensão associada ao inicio da dilatância): devido a tensões localizadas de tração. Segundo MARTIN e CHANDLER (1994), a tensão $\sigma_{c i}$ é de difícil identificação, em especial quando o corpo de prova tem um grande número de micro-fissuras. Para a identificação do $\sigma_{c i}$ recomendam usar a plotagem da curva deformação volumétrica versus deformação axial. Este método baseado no cálculo da deformação volumétrica devido às micro-fissuras mostra a sua dependência das 
constantes elásticas, módulo de elasticidade $(E)$ e o coeficiente de Poisson $(v)$. BRACE et al. (1966) determinaram que a dilatância se inicia numa tensão entre 30 e 50\% da resistência de pico e que, segundo BIENIAWSKI (1967), $\sigma_{c i}$ é a tensão onde se inicia a propagação estável das fissuras, em cujo entorno o módulo de elasticidade é constante. Segundo vários autores, a característica mais importante da região III é a dilatância. Conforme o estudo de HOLZHAUSEN e JOHNSON (1979) entre outros pesquisadores, o crescimento das micro-fissuras é paralelo à direção da carga máxima aplicada.

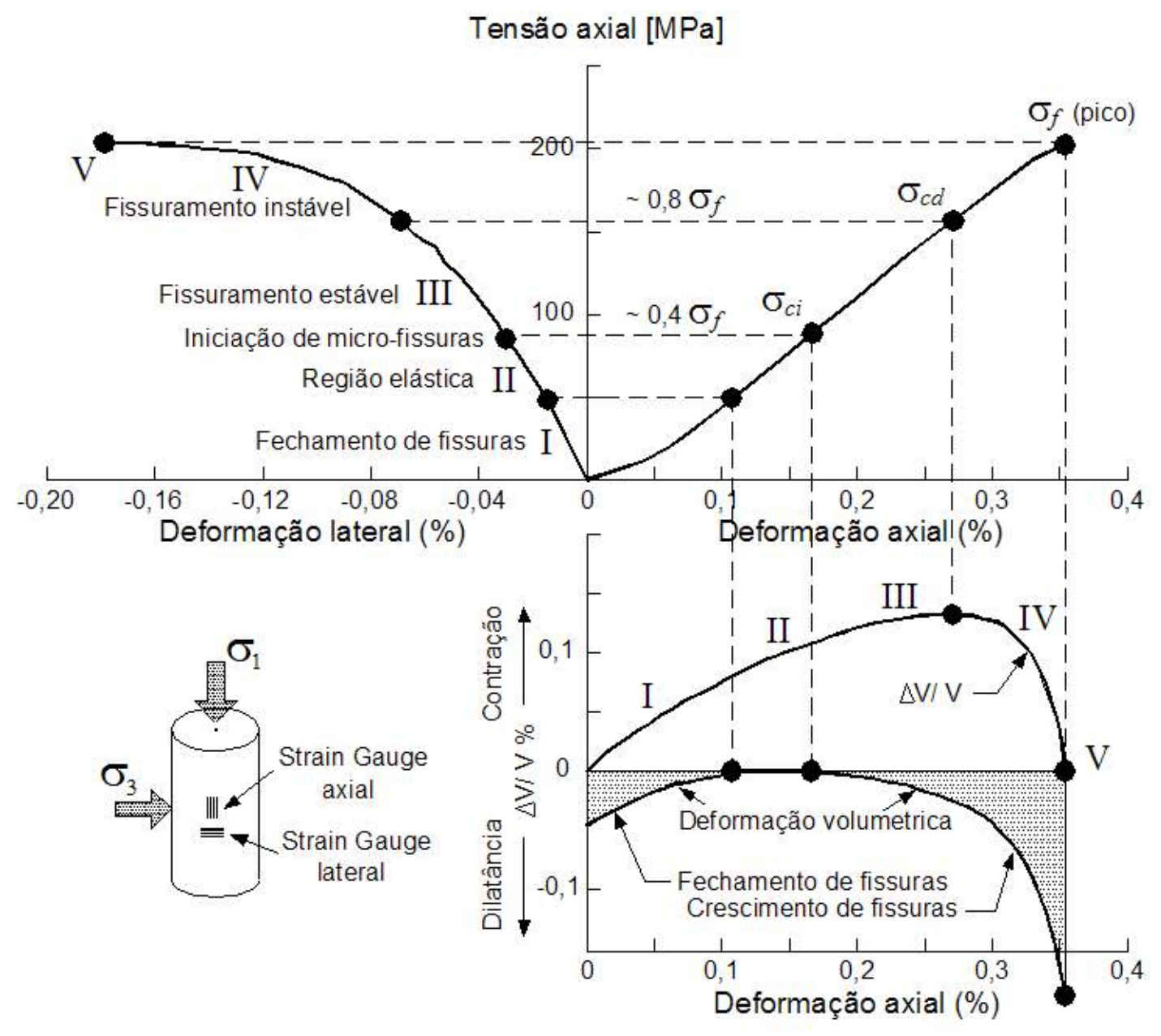

FIGURA 3.2 Curva característica tensão-deformação axial: início de micro-fissuras $\left(\sigma_{c i}\right)$, dano por micro-fissuras $\left(\sigma_{c d}\right)$; resistência de pico $\left(\sigma_{f}\right)$ (MARTIN, 1993).

(2) $\sigma_{c d}$ - tensão de dano por micro-fissuras: esta tensão corresponde ao ponto máximo da deformação volumétrica total, ponto no qual as deformações radiais passam a crescer rapidamente. Segundo BIENIAWSKI (1967), esta tensão dá inicio à propagação instável de micro-fissuras e ocorre tipicamente entre $70 \%$ e $85 \%$ da resistência de pico de curto 
prazo. Segundo MARTIN (1993) e MARTIN e CHANDLER (1994), nesta tensão se iniciam mecanismos de deslizamento ao longo de macro-fissuras, assim como este nível de tensão está associado com a dilatância em maior escala e que corresponderia à resistência de longo prazo.

(3) $\sigma_{f}$ - tensão igual à resistência de pico: Esta tensão marca o início do comportamento pós-pico e é universalmente usada para estabelecer a envoltória de resistência. Além da tensão de pico, a curva tensão versus deformação axial apresenta um rápido decréscimo, que é interrompido por um ou mais intervalos curtos de endurecimento marcados por saltos no decréscimo da tensão axial.

Os resultados dos ensaios de compressão uniaxial com carga constante feitos por SCHMIDTKE e LAJTAI (1985) em amostras do granito Lac du Bonnet foram re-analisados por MARTIN e CHANDLER (1994), que chegaram à conclusão de que, para tensões acima de $70 \%$ da resistência de pico, a ruptura acontece quase imediatamente, FIGURA 3.3a. Conforme os estudos de MARTIN (1997), quando o nível de tensão associado à resistência de longo prazo $\left(\sigma_{c d}\right)$ é normalizada em relação à resistência de pico, ela resulta ser independente da tensão de confinamento conforme apresentado na FIGURA 3.3b.

SCHOLZ (1968), HOLCOMB e MARTIN (1985) e PESTMAN e VAN MUNSTER (1996) estudaram a iniciação das micro-fissuras em amostras de granito, arenito e mármore através de técnicas de emissão acústica. MARTIN (1997) resume os trabalhos destes pesquisadores e segundo os resultados destes autores, para condições confinadas, a superfície de início do dano, no gráfico $\sigma_{1}-\sigma_{3}$, pode ser dada aproximadamente pela seguinte relação:

$$
\sigma_{1}=0,4 \sigma_{c}+n \sigma_{3}
$$

onde $n$ varia de 1,5 a 2 e $\sigma_{c}$ é à resistência a compressão simples.

Cabe salientar que a tensão associada ao instante em que as micro-fissuras préexistentes começam a se propagar ou ter crescimento, está associada ao início do dano por crescimento de fissuras e criação de novas fissuras. Assim, a tensão $\sigma_{c i}$, associada ao início de crescimento de micro-fissuras pode ser chamada de tensão de início de dano $\left(\sigma_{d i}\right)$. 
a)
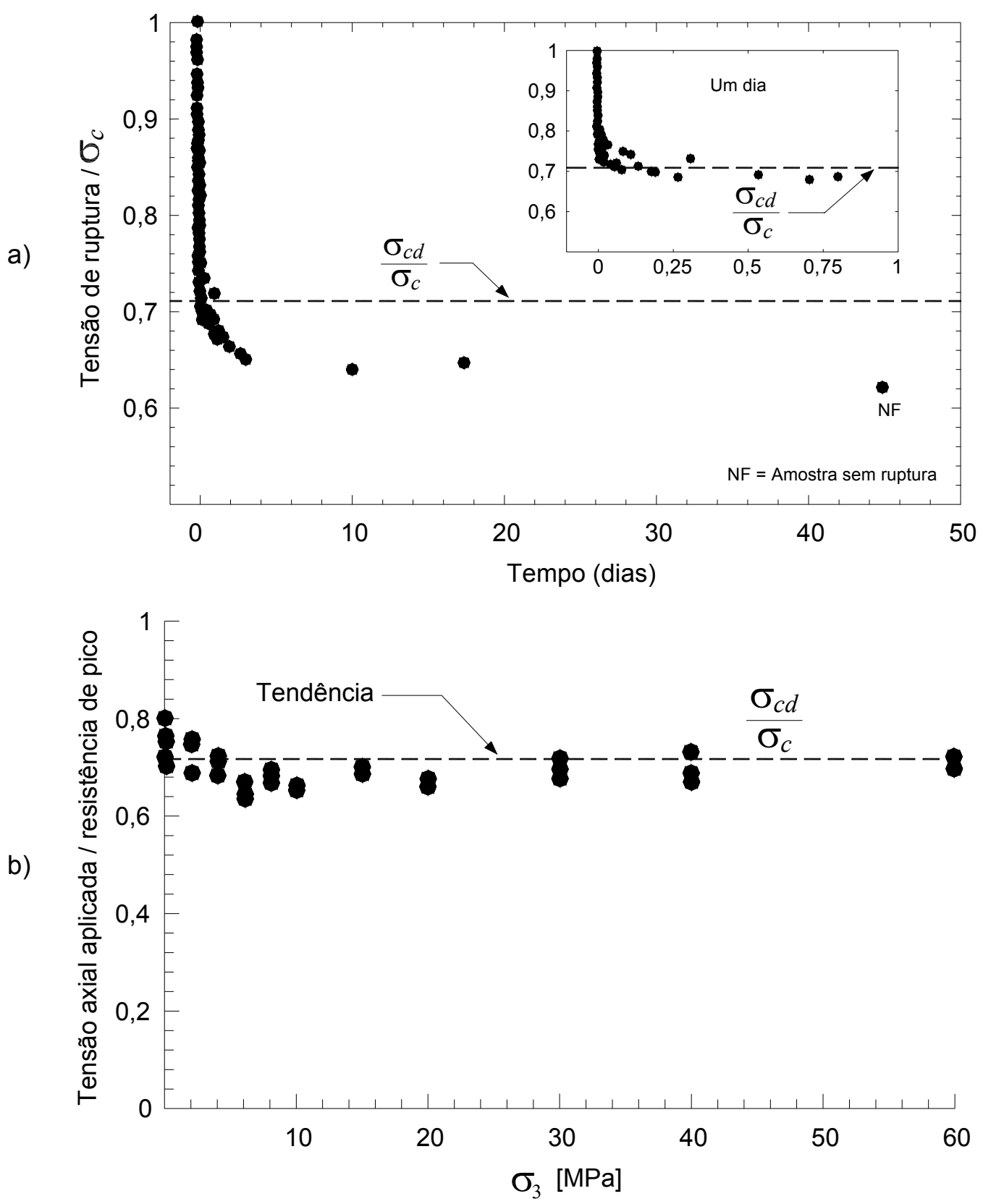

FIGURA 3.3 Granito Lac du Bonnet: (a) resistência de amostras não confinadas submetidas a carga constante de longo prazo (MARTIN e CHANDLER, 1994). (b) relação entre a resistência de longo prazo, normalizada pela resistência de pico, em função da tensão confinante $\sigma_{3}$ (Mod. de MARTIN, 1997).

SCHMIDTKE e LAJTAI (1985) sugerem que uma tensão maior que o valor de $\sigma_{c d}$ é suportada pela rocha por um curto período, de forma que esta não pode ser confiável a longo prazo. MARTIN e CHANDLER (1994) afirmaram que $\sigma_{c i}$ e $\sigma_{c d}$ podem ser possíveis parâmetros do material e que devem ser independentes do volume da amostra. Para 
confirmar esta hipótese, fizeram ensaios em 53 corpos de prova com diâmetros que variaram entre 33 e $300 \mathrm{~mm}$. Os resultados obtidos mostraram que a resistência de pico apresentou uma redução para as amostras maiores, no entanto, nem $\circ \sigma_{c i}$ nem o $\sigma_{c d}$ foram afetados pelo volume da amostra. Estes mesmos autores fizeram ensaios com baixa taxa de carregamento $(0,00075 \mathrm{MPa} / \mathrm{s}, 1000$ vezes menor que a taxa de carregamento normal), ensaiaram quatro amostras com diâmetro de $200 \mathrm{~mm}$, que apresentaram ruptura numa tensão associada a $\sigma_{c d}$. Estas amostras, contudo, não apresentaram o pico da deformação volumétrica comum aos ensaios convencionais. Baseados nestes resultados, concluíram que $\sigma_{c d}$ é a verdadeira resistência de pico do corpo de prova num ensaio de compressão uniaxial padrão e que $\circ \sigma_{c i}$ e $\circ \sigma_{c d}$ são parâmetros independentes da escala.

\subsection{Mobilização das Componentes de Resistência durante a Ruptura}

Segundo o critério de ruptura de MOHR-COULOMB, a resistência da rocha intacta é composta por duas componentes ou parcelas, a resistência coesiva e a resistência ao atrito, assumindo-se geralmente que são mobilizadas simultâneamente.

MARTIN e CHANDLER (1994) estudaram o dano induzido por micro-fraturamento através de ensaios cíclicos de carga-descarga em compressão uniaxial e triaxial, com o objetivo de estudar o comportamento pós-ruptura. Estes ensaios foram realizados em corpos de prova cilíndricos com diâmetro de $63 \mathrm{~mm}$ do granito Lac du Bonnet. Por sua vez, NÓBREGA (1994) estudou o comportamento mecânico de rocha calcária e de argamassa quando submetidas a carregamentos cíclicos em compressão uniaxial e correlacionou a degradação da resposta do material ao trabalho dispendido ao longo do ensaio. SU et al. (2000) também estudaram o dano induzido em amostras de granito da França através de ensaios de compressão cíclicos uniaxial e triaxial, com a finalidade de estudar a variação das propriedades elásticas e plásticas do granito em relação ao dano. Estes ensaios foram feitos em corpos de prova cilíndricos com diâmetro de $60 \mathrm{~mm}$ e 120 $\mathrm{mm}$ de altura.

Segundo os estudos de MARTIN e CHANDLER (1994), a mobilização das componentes de resistência de coesão e de atrito não é simultânea. A resistência ao atrito somente é mobilizada depois de uma significante perda da resistência coesiva. Estes autores usaram a aproximação de GRIFFITH definida por COOK (1965) para explicar a perda progressiva da coesão e a mobilização da resistência ao atrito quando o corpo de prova sofre micro-fraturamento (dano). Consegue-se explicar a mobilização da resistência 
ao atrito da seguinte forma. Primeiro ocorrem deformações não elásticas. Além disso, o atrito engloba a componente residual, $\phi_{b}$, e a componente de intertravamento e de rugosidade, $\phi_{i}$, de tal forma que, o atrito total pode ser expresso como $\phi_{b+i}$, conforme se mostra nas FIGURAS 3.4 e 3.5. A componente devido ao intertravamento por rugosidade diminui com o acréscimo do dano, desde um valor máximo até zero, enquanto a componente residual é mobilizada.

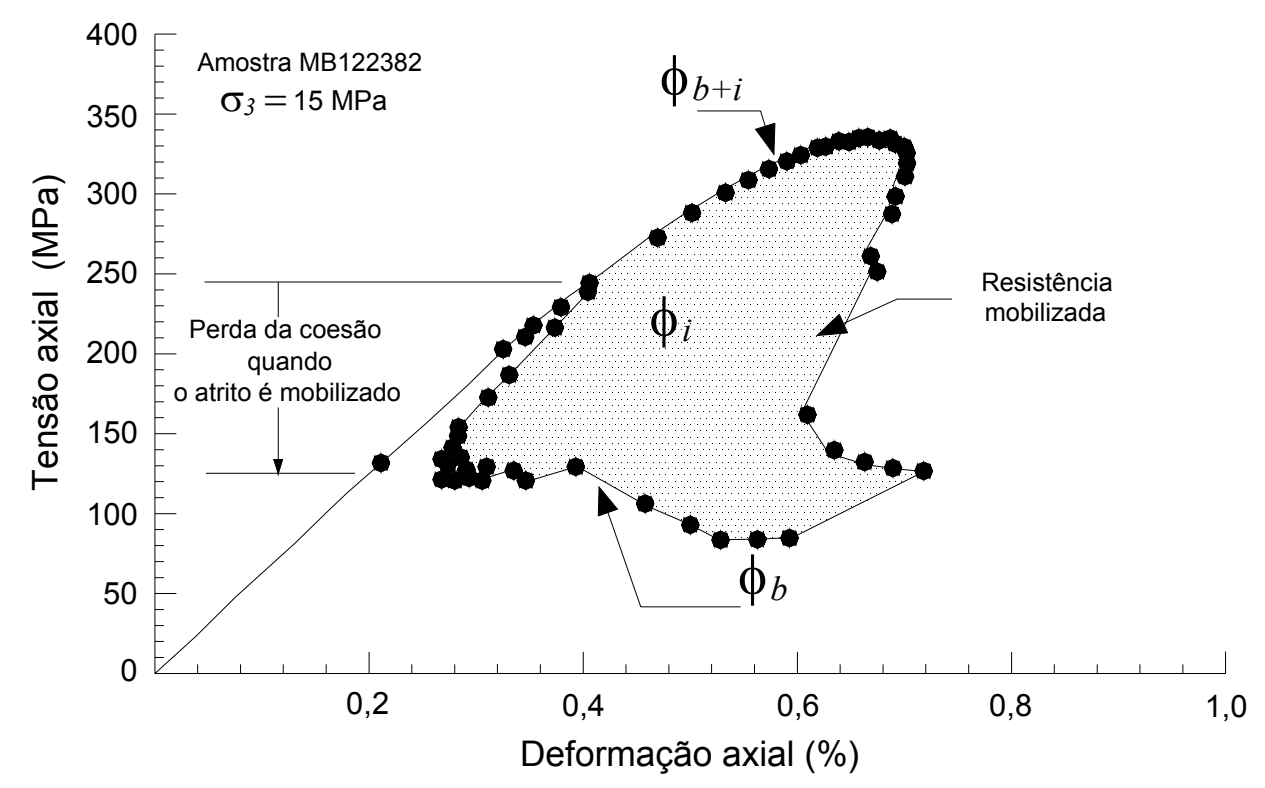

FIGURA 3.4 Perda da resistência coesiva e mobilização da resistência ao atrito em função da deformação axial (MARTIN e CHANDLER, 1994).

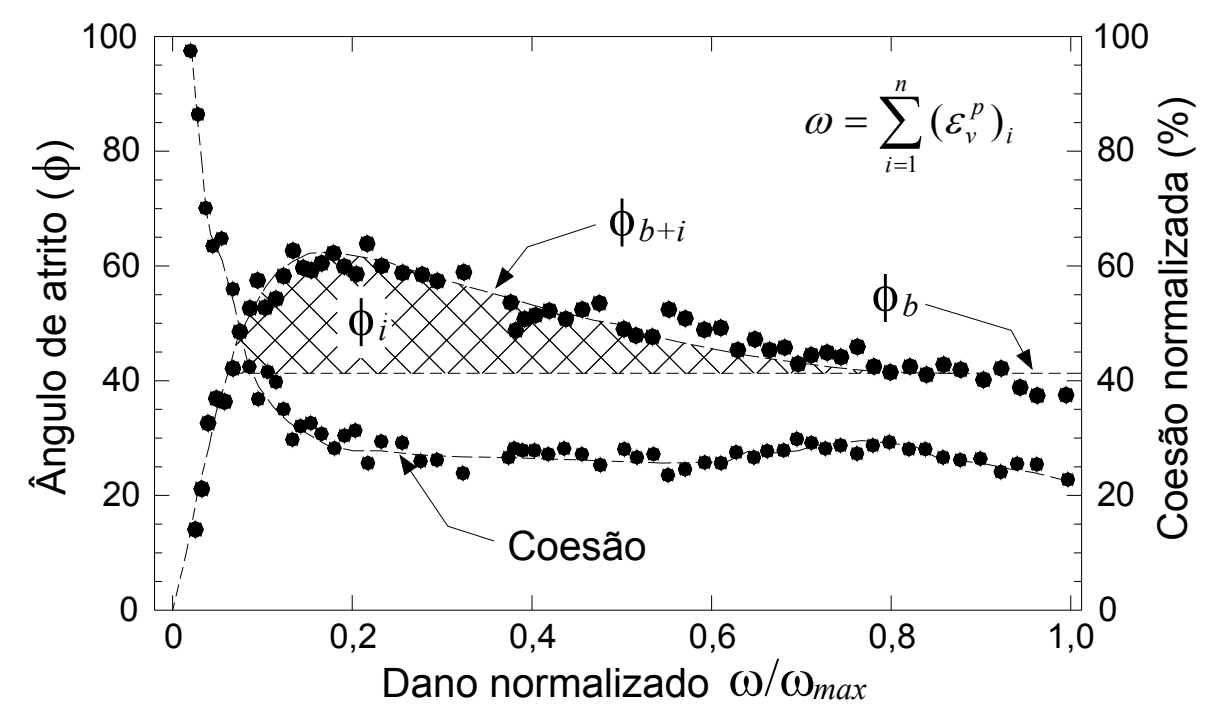

FIGURA 3.5 Ângulo de atrito total e resistência coesiva normalizada em relação à resistência de pico versus o dano normalizado em relação ao dano máximo (MARTIN e CHANDLER, 1994). 
Na FIGURA 3.4 apresenta-se um exemplo do fraturamento progressivo, onde se ilustra a perda da coesão e a mobilização do atrito. Na FIGURA 3.5 se apresenta o gráfico do ângulo de atrito mobilizado e a resistência coesiva normalizada em relação à resistência de pico versus o dano normalizado em relação ao dano máximo.

Salienta-se que o dano, $\omega$, é expresso como a somatória da deformação volumétrica permanente de cada incremento de dano (ciclo de carga e descarga), conforme definido por MARTIN e CHANDLER (1994):

$$
\omega=\sum_{i=1}^{n}\left(\varepsilon_{v}^{p}\right)_{i}
$$

Assim, conforme a FIGURA 3.5, o atrito total máximo, $\phi_{b+i}$, (atrito de pico) só é atingido com a máxima perda da resistência coesiva e conforme o acréscimo do dano, o ângulo de atrito diminui gradualmente para o seu valor residual $\left(\phi_{b}\right)$.

Segundo SU et al. (2000), o dano do granito está associado com o amolecimento do material. Conforme os resultados destes autores, tem-se perda da coesão em relação ao dano, de $28 \mathrm{MPa}$ para $3 \mathrm{MPa}$ para o granito danificado com $0,25 \%$ da deformação volumétrica irreversível. Por sua vez, o atrito tem um ligeiro acréscimo de $45,8^{\circ}$ para $48,4^{\circ}$. Além disso, com o crescimento de micro-fissuras numa direção preferencial, paralela a $\sigma_{1}$, durante o carregamento de compressão aparece a anisotropia das propriedades mecânicas, fato que ainda é de difícil quantificação. Os resultados obtidos por SU et al. (2000) mostram similitude com os obtidos por MARTIN e CHANDLER (1994) na mobilização não simultânea das componentes da resistência no critério de ruptura de Mohr-Coulomb.

HAJIABDOLMAJID (2001), baseado nos estudos de MARTIN (1993) e MARTIN e CHANDLER (1994), adotou o modelo de amolecimento da coesão-ganho do atrito, em que as componentes da resistência, resistência coesiva e de atrito, são dependentes da deformação plástica. Ele ilustra, num diagrama esquemático, conforme a FIGURA 3.6, a perda da coesão e a mobilização da resistência ao atrito em ensaios de compressão.

O aparecimento de micro-fissuras e a formação de macro-planos de cisalhamento levam, eventualmente, à máxima mobilização da resistência ao atrito após a perda significativa da coesão inicial $\left(c_{i}\right)$ para o seu valor residual $\left(c_{r}\right)$. A resistência coesiva governa a resistência do material nos primeiros estágios da ruptura, sendo a perda da coesão por micro-fraturamento o mecanismo de ruptura predominante. Assim, a resistência coesiva é gradualmente destruída por este micro-fraturamento devido às tensões de tração localizadas e por mecanismos de coalescência de micro-fissuras. A 
resistência ao atrito dependente da tensão normal é mobilizada completamente só depois que a componente coesiva for significativamente reduzida.

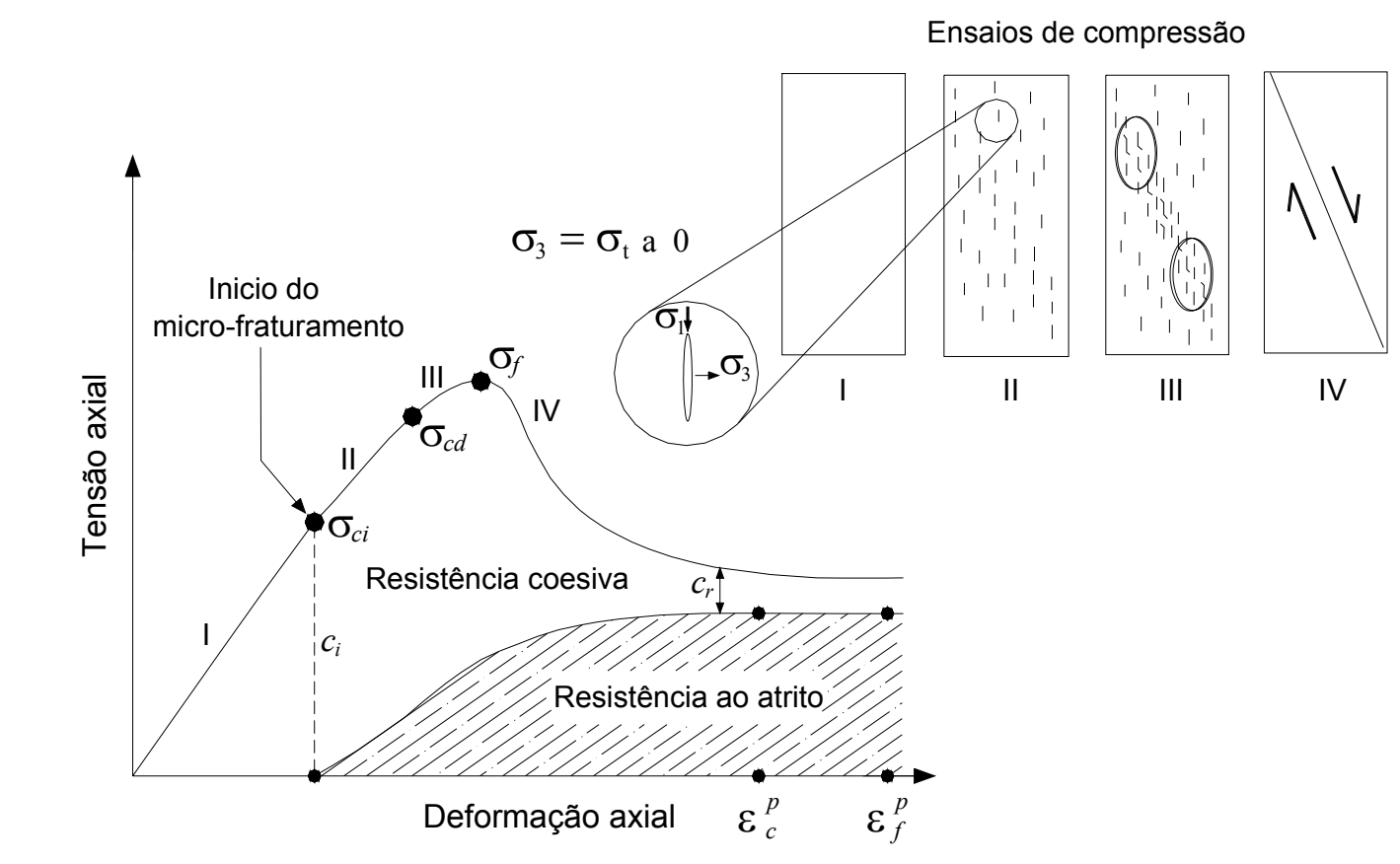

FIGURA 3.6 Mobilização das componentes da resistência no modelo de amolecimento da coesão-ganho do atrito em ensaios de compressão (HAJIABDOLMAJID, 2001).

HAJIABDOLMAJID e KAISER (2002) ressaltaram que durante o processo de ruptura, ocorre uma redução da resistência derivada das pontes rochosas (coesão), ao passo que a resistência ao atrito é gradualmente mobilizada, tendo-se um rearranjo dos blocos desintegrados ou deformados por cisalhamento ao longo das novas superfícies criadas. Também afirmam que, apesar de aplicar uma tensão de confinamento uniforme ao corpo de prova, o confinamento local é altamente variável devido à heterogeneidade, podendo chegar a ser de tração. Este fato levaria à mobilização não simultânea das componentes da resistência, FIGURA 3.7.

NEMAT-NASSER e HORII (1982), HORII e NEMAT-NASSER (1985), a partir de modelos físicos em argamassa, analisaram o início e a propagação de uma fratura inclinada submetida à compressão. Explicaram e demonstraram experimentalmente que a instabilidade e a conseqüente ruptura só ocorrem na presença de tensões de tração com direção normal às fraturas axiais, sendo estas tensões de tração decorrentes da redistribuição de tensões. Assim, as afirmações de HAJIABDOLMAJID (2001) e HAJIABDOLMAJID e KAISER (2002) ficam bem fundamentados nestes estudos. 


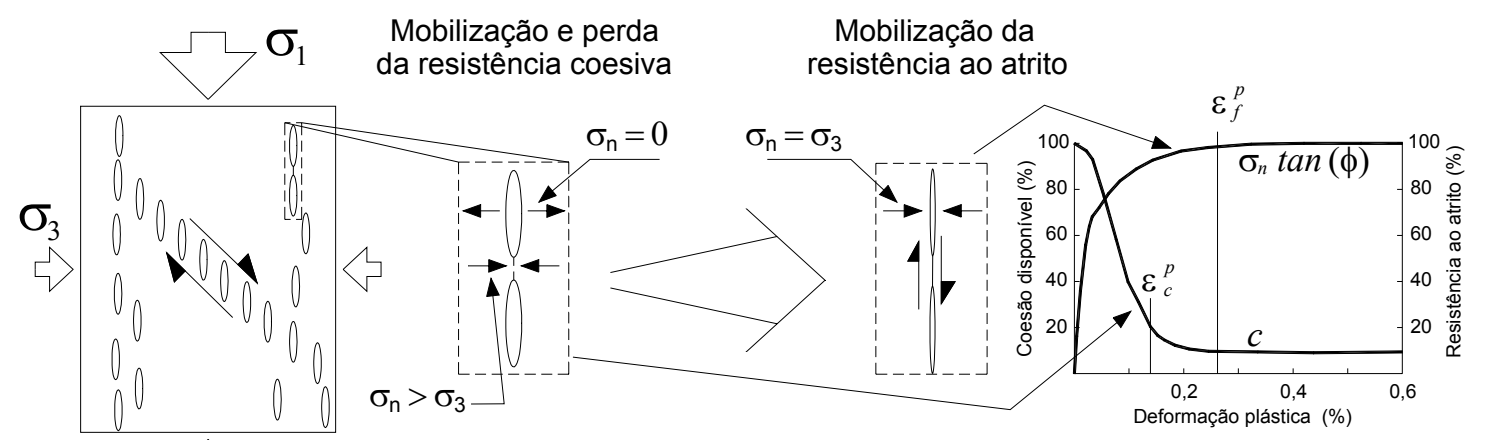

FIGURA 3.7 Dano induzido por mecanismos de tração, levando à mobilização não simultânea das componentes da resistência (HAJIABDOLMAJID e KAISER, 2002).

Conforme os resultados de MARTIN e CHANDLER (1994), NÓBREGA (1994) e SU et al. (2000), os parâmetros elásticos como o módulo de elasticidade $(E$ ) e o coeficiente de Poisson $(v)$ variam em relação ao dano. A plotagem do módulo de elasticidade e o coeficiente de Poisson versus o dano para o granito Lac du Bonnet é apresentada na FIGURA 3.8, a qual mostra uma redução gradual do módulo de elasticidade conforme o acréscimo do dano (MARTIN e CHANDLER, 1994).

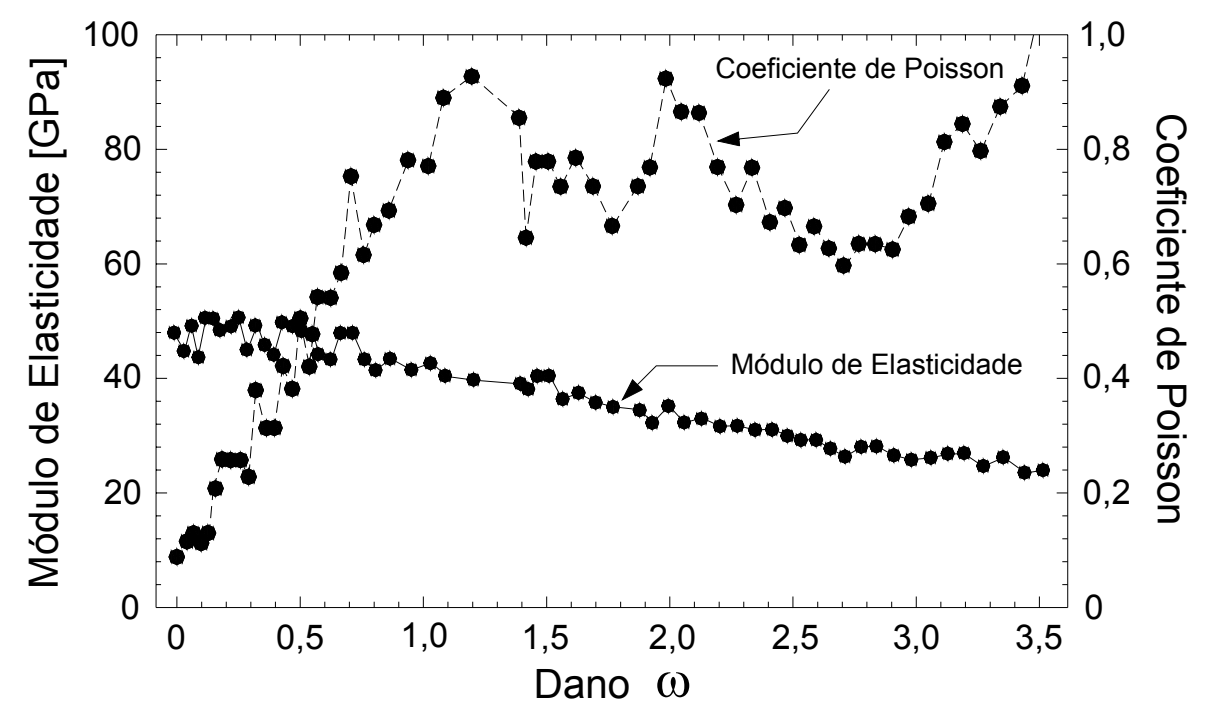

FIGURA 3.8 Variação do módulo de elasticidade e coeficiente de Poisson em função do dano (MARTIN e CHANDLER, 1994). 
Na FIGURA 3.9 apresentam-se as variações do módulo de elasticidade da argamassa* e do calcário Irati versus os ciclos de carregamento. Ocorre uma redução gradual do módulo de elasticidade nos ciclos de carga-descarga (dano) que antecedem à ruptura (NÓBREGA, 1994).

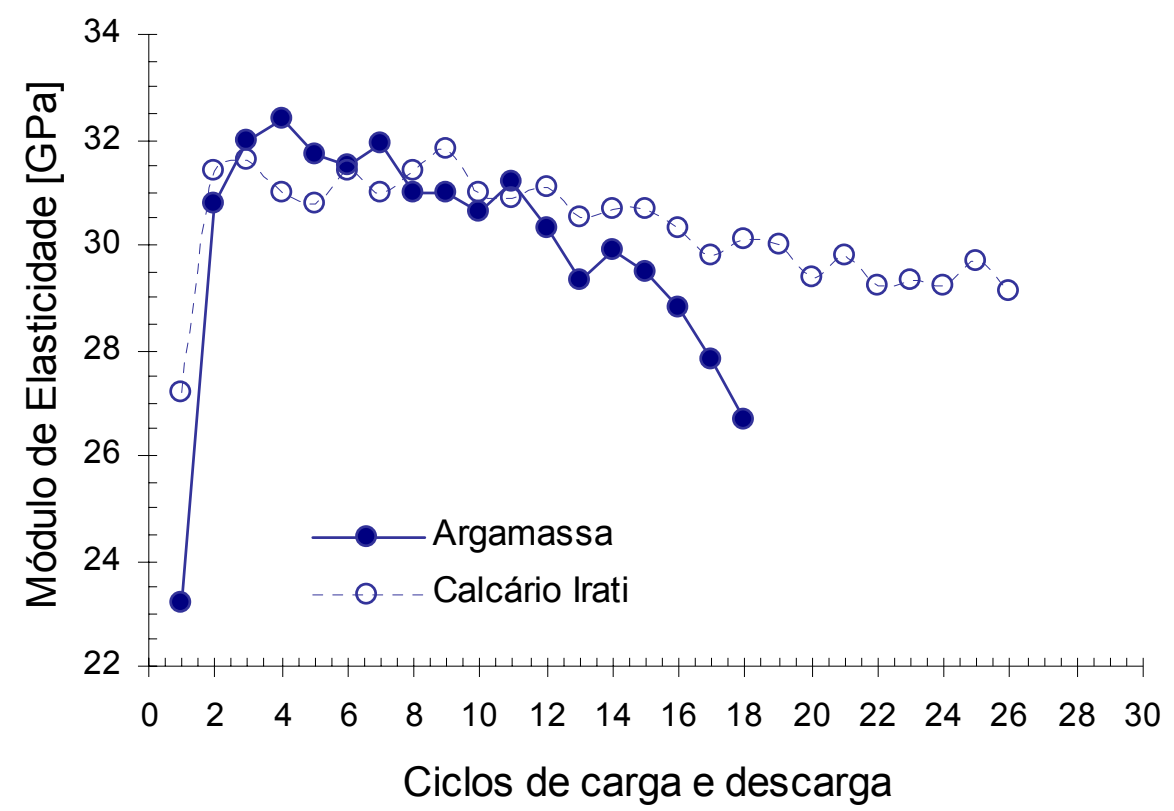

FIGURA 3.9 Variação do Módulo de elasticidade em função dos ciclos de carregamento para a argamassa e o calcário Irati (NÓBREGA, 1994).

Por outro lado, o coeficiente de Poisson sofre um acréscimo nítido quando o nível de tensões aplicado (ciclo de carga-descarga) supera a tensão $\sigma_{c d}$, que estaria refletindo basicamente o crescimento das micro-fraturas. Segundo MARTIN e CHANDLER (1994), o acréscimo do coeficiente de Poisson acima de 0,5 só representa a relação das deformações laterais relativas às deformações axiais, e esta deixa de ser uma constante elástica. Observações similares foram feitas por BIENIAWSKI (1967).

\subsection{Algumas Relações entre Ensaios de Laboratório e os Taludes}

Como conseqüência da escavação em mineração a céu aberto, e conforme discutido no capítulo 2, há concentrações de tensões compressivas e de cisalhamento nas regiões do pé do talude. Estas tensões chamadas de tensões induzidas, conforme a sua magnitude, podem gerar algum tipo de perturbação, ou mais propriamente dano. O maciço

* A argamassa teve uma relação cimento-areia de 1:2 e de água-cimento de 0,38, o cimento foi o CPE 32. 
rochoso, como um corpo de prova em laboratório quando submetido a um sistema de cargas aplicadas, pode sofrer danificação, que pode se manifestar fisicamente como fraturas, fato que se pretende abordar nesta dissertação.

Conforme os resultados de ensaios de MARTIN e CHANDLER (1994) em granito e de NÓBREGA (1994) em rocha calcária e argamassa, o módulo de elasticidade $(E$ ) tem uma diminuição com o acréscimo do dano. Assim, o corpo de prova, desde que tenha micro-fraturas e fraturas consideradas como descontinuidades, poderia ser concebido como representativo de um maciço rochoso em pequena escala. Se assumirmos válida esta comparação, então pode-se dizer que, o maciço rochoso que também sofre dano devido às tensões induzidas (fraturamento), teria variação do módulo $E$. Os mecanismos de ruptura que acontecem num corpo de prova podem também se apresentar em taludes de mineração, o que sugere que, o maciço rochoso além de ter perda da resistência coesiva também sofre uma diminuição da sua rigidez.

Um outro fato de comparação a se fazer são os ensaios de compressão simples com baixas taxas de carregamento, como os apresentados por MARTIN e CHANDLER (1994), com taxa de carregamento 1000 vezes menor que a taxa de carregamento usual, nos quais a resistência do corpo de prova resulta estar associada à tensão $\sigma_{c d}$, aproximadamente entre $70 \%$ e $85 \%$ da resistência de pico (curto prazo). Para casos de minas a céu aberto e de acordo com os planos de escavação, os taludes são construídos num período de tempo relativamente longo, como por exemplo, a escavação dos taludes da Mina Chuquicamata, Chile (CALDERÓN et al., 2003), onde os taludes têm em média altura de $750 \mathrm{~m}$ e foram construídos em aproximadamente 90 anos. Mesmo para taludes escavados na escala de tempo de poucos anos, a velocidade de carregamento de ensaios representativos deve ser muito menor que a usualmente adotada em laboratório. 


\section{Capítulo 4}

\section{Modelagem Numérica: Aproximação de Meio Contínuo}

\subsection{Introdução}

Conforme a literatura, a aplicação da teoria da plasticidade é ampla, tendo seu início no estudo de metais. Sabe-se que, quando uma carga externa é aplicada a um corpo provoca tensões e deformações no corpo. Quando a carga externa é retirada, o corpo pode ou não retornar a sua forma ou configuração original. Se o corpo retorna a sua configuração original quando as cargas são retiradas, então o corpo sofreu deformação elástica. Se o corpo não retorna a sua configuração original, retendo uma parcela da deformação total quando retiradas as cargas aplicadas, então o corpo sofreu uma deformação inelástica ou plástica.

Como exemplo, mostram-se na FIGURA 4.1 os aspectos principais do comportamento plástico real e idealizado para um material metálico, quando submetido a carregamento uniaxial, seguido de descarregamento. As deformações plásticas aparecem simultâneamente às tensões que excedem um determinado limite, denominado limite de escoamento.

Duas regiões ficam destacadas para uma situação de carga-descarga-recarga. A primeira delas o trecho $\mathrm{OA}$, que está limitada superiormente por uma tensão $\sigma_{A}$, que caracteriza o regime elástico linear. Nela, para sucessivas situações de carga e descarga, o caminho percorrido é o mesmo sem o aparecimento de deformações residuais, irreversíveis ou plásticas. A segunda região caracteriza o regime plástico. Este regime é evidenciado quando o corpo de prova é solicitado por um nível de tensão $\sigma_{B}>\sigma_{A}$, de modo que a descarga não ocorre mais pelo mesmo caminho percorrido no carregamento, mas por um caminho de trajetória aproximadamente paralela ao regime elástico, 
resultando, conseqüentemente, no nível de tensão nula, uma deformação residual denominada de deformação plástica. Desse modo, pode-se dizer que a deformação total, $\varepsilon$, correspondente ao nível de tensão $\sigma_{B}$ se compõe de duas parcelas como expresso na equação seguinte:

$$
\varepsilon=\varepsilon^{e}+\varepsilon^{p}
$$

Onde, $\varepsilon^{e}$ é a parcela elástica, e $\varepsilon^{p}$ a parcela plástica. No trecho $\mathrm{AB}$ ocorre um comportamento elasto-plástico.

Com uma nova etapa de carga, o caminho é novamente linear, estendendo-se até um nível de tensão $\sigma_{C}$, maior que $\sigma_{A}$. A partir daí, a tendência desta curva é a de atingir a curva OD, que seria definida se o carregamento tivesse sido monotônico, sem a primeira descarga. Nessa nova etapa de carga, a tendência de escoamento é caracterizada por um novo valor, definido em função do aparecimento da deformação plástica anterior, fenômeno esse que é chamado de encruamento. Por outro lado, como a trajetória de recarga não segue a trajetória de carregamento original; a deformação será dependente do histórico de tensões aplicadas, isto quando ocorre deformação plástica.

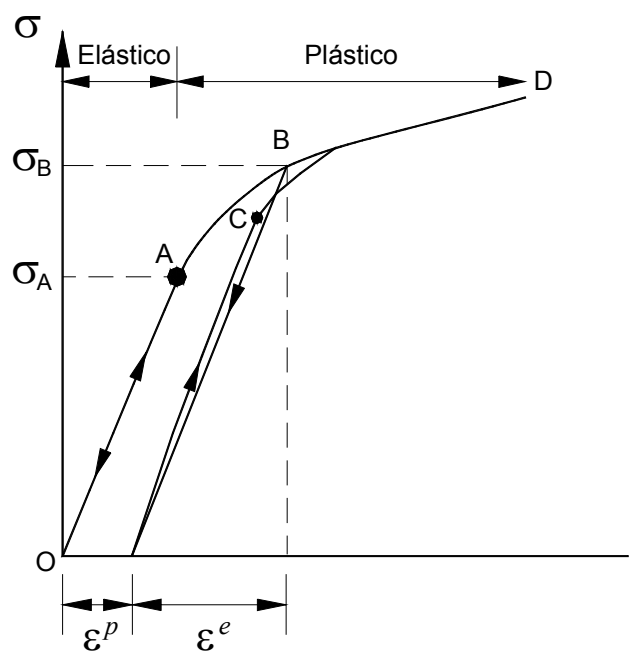

a) Real

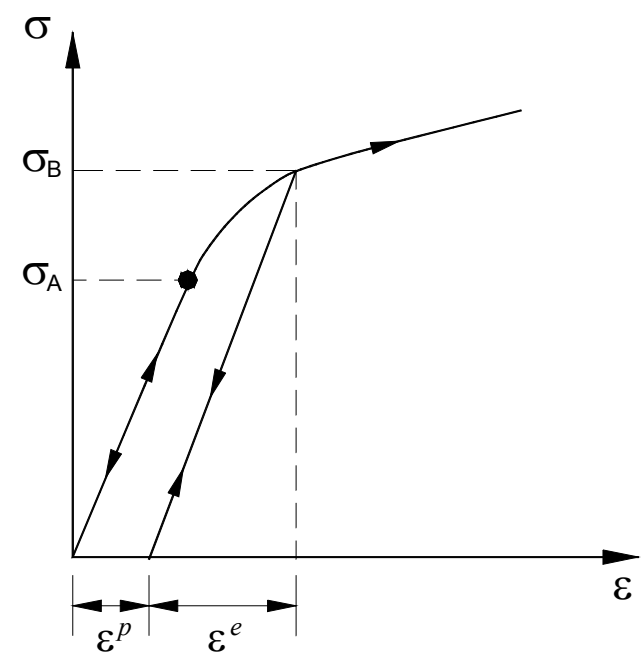

b) Idealizado

FIGURA 4.1 Comportamento plástico de um material metálico: (a) real (b) idealizado (Apud. PROENÇA, 1988).

O regime de comportamento plástico em geomateriais (rochas e solos) está associado ao aparecimento de deformações irreversíveis ou permanentes, quando se anula a solicitação a que o corpo tenha estado sujeito. As deformações irreversíveis em geomateriais estão associadas a dois mecanismos: (1) Rearranjo de materiais granulares 
soltos ou rochas pobremente cimentadas com alta porosidade quando submetidas a carregamento. Estes materiais soltos sob carregamento atingem um travamento de tal forma que obtêm ganho de densidade com a deformação irreversível. (2) Aparecimento de micro-fissuras em materiais de baixa porosidade como as rochas duras, fenômeno que também se dá no concreto. Estas micro-fissuras representam a deformação plástica ou irreversível e podem ser de natureza intergranular e trans-granular, dependendo dos ambientes das tensões.

Conforme a literatura, os processos de ruptura em geomateriais são acompanhados por dois fenômenos: i) o efeito do confinamento na resistência e ii) as mudanças de volume. Com alto confinamento, os geomateriais têm maior resistência, de modo que, por este efeito, a resistência ao atrito sofre um acréscimo com o confinamento. As mudanças de volume são um fenômeno significativo que acompanha o processo de ruptura em todos os níveis de confinamento.

Nos itens subseqüentes, será feito um breve resumo do modelo elasto-plástico de Mohr-Coulomb e das funções a serem implementadas no modelo original de MohrCoulomb, que consideram o amolecimento da resistência coesiva e a mobilização do atrito, em função das deformações plásticas (dano), com a finalidade de considerar a mobilização não simultânea das componentes de resistência.

\subsection{Plasticidade em Análises de Ruptura de Rochas}

Sabe-se que a análise elástica não leva em consideração o importante fenômeno correspondente às deformações irreversíveis dos geomateriais. Assim, modelos baseados na plasticidade podem representar melhor o comportamento tanto dos solos, como das rochas.

Na FIGURA 4.2, apresenta-se o diagrama típico tensão-deformação para rochas duras em compressão. A elasticidade é apropriada para representar o trecho que vai do ponto $\mathrm{A}$ até o limite do regime elástico (ponto B). Quando a amostra é carregada com uma carga acima do limite elástico (por exemplo ponto $\mathrm{C}$ ), e descarregada, permanecem as deformações plásticas ou deformações permanentes, $\varepsilon^{p}$, de tal forma que, numa análise para o caso do ponto $C$, devem-se levar em consideração as deformações plásticas. $A$ teoria que leva em consideração as deformações plásticas é conhecida como a teoria da plasticidade. O comportamento dos geomateriais na região plástica varia de material para material. Vários critérios de plastificação têm sido desenvolvidos para diferentes materiais e caracterizados conforme o seu comportamento durante a ruptura. No entanto, a 
caracterização do comportamento da rocha (FIGURA 4.2b), quando submetida a carregamentos, por vários modelos constitutivos não significa que o material vai se comportar exatamente conforme os modelos idealizados, que são aproximações matemáticas da descrição do comportamento complexo do material real.

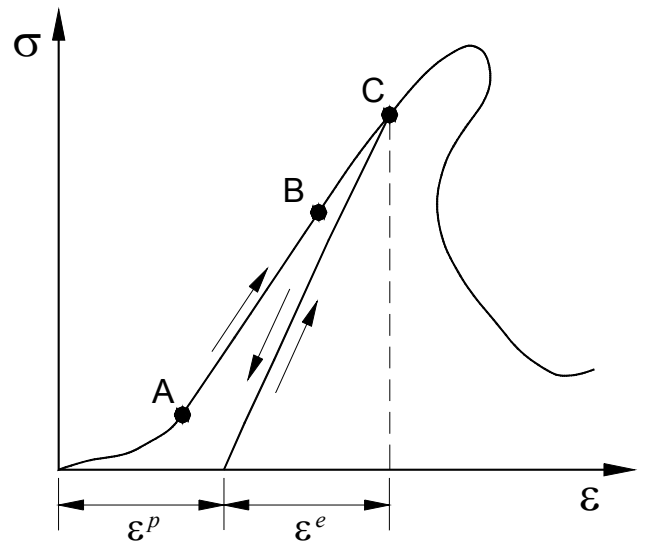

(a)

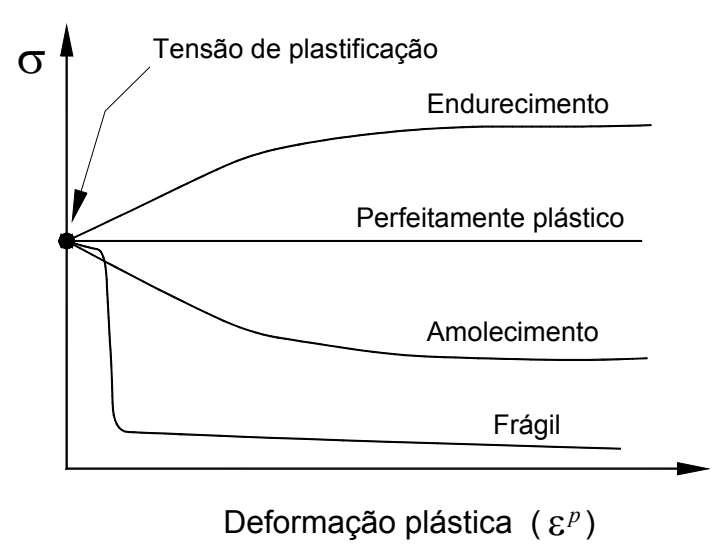

(b)

FIGURA 4.2 (a) Diagrama esquemático tensão-deformação para rochas duras (b) caracterização do comportamento do geomaterial por modelos constitutivos (Apud. HAJIABDOLMAJID, 2001).

\subsubsection{Função de plastificação}

A plasticidade é caracterizada pela existência de um limite chamado de plastificação, depois do qual aparecem as deformações permanentes. Sendo assim, o primeiro passo para os modelos matemáticos é estabelecer o limite de plastificação de um material. O critério de plastificação pode ser definido como o limite das deformações elásticas. Assim, a função de plastificação, $f$, é comumente empregada para distinguir o estado plástico do elástico, sendo expressa pela combinação do estado de tensões (CHEN e BALADI, 1984 e DESAI e SIRIWARDANE, 1984). Assim, seja $f$ uma função escalar do estado de tensões do material que, no caso na EQUAÇÃO 4.2, mostra o critério de plastificação para um material isotrópico e pode ser expressa em termos das tensões principais, como:

$$
f=f\left(\sigma_{1}, \sigma_{2}, \sigma_{3}\right)
$$

De forma geral, a condição $f(\sigma)<0$ corresponde ao regime elástico do material, enquanto que $f(\sigma)=0$ corresponde ao aparecimento de deformações irreversíveis. A 
função $f$ é chamada de função de plastificação e a superfície $f(\sigma)=0$ no espaço das tensões principais é a superfície de plastificação do material.

Um material é denominado de perfeitamente plástico ou com endurecimento ou amolecimento por deformações plásticas conforme a sua função de plastificação, seja fixa ou admita mudanças (expansão/contração) em função das deformações plásticas.

$\mathrm{Na}$ teoria da plasticidade chamada de teoria incremental (HILL, 1950), a qual relaciona as taxas (incrementos) de deformações plásticas com as tensões existentes e as taxas de tensões (incrementos), os materiais podem ser divididos em: (i) materiais perfeitamente plásticos e (ii) materiais com comportamento de endurecimento/amolecimento por deformações.

Para materiais perfeitamente plásticos, a função de plastificação é postulada como:

$$
f\left(\sigma_{i j}\right)=0
$$

onde $\sigma_{i j}$ é o tensor de tensões simétrico. Neste material, a função de plastificação não varia, e a superfície de plastificação é fixa. Assim, com a ocorrência de deformações plásticas, as tensões percorrem ao longo da superfície de plastificação.

Devido ao fluxo plástico, em certos materiais ocorre o endurecimento com as deformações plásticas. Para este caso, a função de plastificação varia com as deformações permanentes. Estas deformações plásticas aparecem somente quando as tensões estão situadas na superfície de plastificação e ela se desloca para fora; desta forma, a superfície de plastificação é deslocada ou estendida pelas tensões. Para considerar o efeito do endurecimento por deformação plástica, a função de plastificação é descrita como (HILL, 1950; CHEN e BALADI, 1984):

$$
f\left(\sigma_{i j}, \varepsilon_{i j}^{p}\right)=0
$$

onde $\varepsilon_{i j}^{p}$ são as componentes do tensor de deformações plásticas, as quais representam o parâmetro de endurecimento. Na literatura, a EQUAÇÃO 4.4 é referida como a hipótese de endurecimento por deformação plástica.

A definição do comportamento de fluxo plástico de materiais é importante no desenvolvimento das relações plásticas tensão-deformação. O fluxo plástico é definido através da lei de fluxo. 


\subsubsection{Lei de Fluxo}

Quando o estado de tensões atinge o critério de plastificação $(f)$, o material sofre deformações plásticas. Isto é definido como o fluxo plástico. Na teoria da plasticidade, a direção dos vetores de deformação plástica é definida através da lei de fluxo, assumindose a existência de uma função chamada de potencial plástico, à qual as componentes de deformação incremental são ortogonais. Então, os incrementos da deformação plástica podem ser expressos como:

$$
d \varepsilon_{i j}^{p}=\lambda \frac{\partial g}{\partial \sigma_{i j}}
$$

onde $g$ é a função do potencial plástico, e $\lambda$ é um fator escalar positivo de proporcionalidade. A função de potencial plástico de uma forma geral pode estar expressa do seguinte modo:

$$
g\left(\sigma_{i j}, \varepsilon_{i j}^{p}\right)=0
$$

Para alguns materiais, as funções de plastificação $(f)$ e de potencial plástico $(g)$ podem ser assumidas como iguais, considerando-se que tais materiais seguem a lei de fluxo associativa. No entanto, para muitos geomateriais, as funções de plastificação $(f)$ e de potencial plástico $(g)$ são diferentes. Estes materiais seguem a lei de fluxo nãoassociativa (DESAI e SIRIWARDANE, 1984 e VERMEER e DE BOSRT, 1984).

\subsubsection{Parâmetro de Endurecimento/Amolecimento}

$\mathrm{Na}$ teoria da plasticidade, um parâmetro é introduzido para considerar o comportamento pós-ruptura dos materiais durante a plastificação, o qual pode envolver perda (amolecimento) ou ganho (endurecimento) da resistência. Assim, a superfície de plastificação deve ser movida para fora no caso do endurecimento e para dentro no caso do amolecimento, de modo que um novo valor do incremento da deformação plástica pode ser obtido.

Uma definição possível para o parâmetro de endurecimento é a deformação volumétrica (VERMEER e DE BORST, 1984) definida como:

$$
\varepsilon_{v}^{p}=\varepsilon_{1}^{p}+\varepsilon_{2}^{p}+\varepsilon_{3}^{p}
$$

Uma hipótese alternativa para o endurecimento por deformação é relacionar uma certa medida da deformação plástica total, $d \varepsilon^{p}$, conhecida como o incremento de deformação plástica e definida como (HILL, 1950): 


$$
d \varepsilon^{p}=+\sqrt{\frac{2}{3}\left(d \varepsilon_{i j}^{p} d \varepsilon_{i j}^{p}\right)}
$$

Esta deformação plástica, quando integrada nos limites da trajetória de deformações, fornece a deformação plástica efetiva representada como:

$$
\bar{\varepsilon}^{p}=+\sqrt{\frac{2}{3}\left(\varepsilon_{1}^{2}+\varepsilon_{2}^{2}+\varepsilon_{3}^{2}\right)}
$$

onde o parâmetro $\bar{\varepsilon}^{p}$ representa a deformação plástica efetiva atual e, ao mesmo tempo, representa o histórico das deformações plásticas (HILL, 1950).

A EQUAÇÃO 4.8 pode ser representada em termos dos incrementos das deformações principais, como na EQUAÇÃO 4.10 (VERMEER e DE BORST, 1984). O parâmetro $\bar{\varepsilon}^{p}$ está relacionado diretamente ao dano induzido e/ou acumulado:

$$
\bar{\varepsilon}^{p}=\int \sqrt{\frac{2}{3}\left(d \varepsilon_{1}^{p} d \varepsilon_{1}^{p}+d \varepsilon_{2}^{p} d \varepsilon_{2}^{p}+d \varepsilon_{3}^{p} d \varepsilon_{3}^{p}\right)} d t
$$

onde, $d \varepsilon_{1}^{p}, d \varepsilon_{2}^{p}$ e $d \varepsilon_{3}^{p}$ são os incrementos das deformações plásticas principais.

\subsection{Critério de ruptura de Mohr-Coulomb}

Conforme o critério de ruptura de Mohr-Coulomb, a resistência ao cisalhamento sofre acréscimo com o acréscimo das tensões normais no plano de ruptura. Este critério, em sua forma mais simples, pode ser expresso como:

$$
\tau=c+\sigma_{n} \tan \phi
$$

onde:

$\tau$ : Resistência ao cisalhamento no plano de ruptura;

$c$ : Resistência coesiva;

$\phi:$ Ângulo de atrito;

$\sigma_{n}$ : Tensão normal ao plano de ruptura.

O critério de ruptura de Mohr-Coulomb é apresentado graficamente na FIGURA 4.3. O conceito do círculo de Mohr pode ser usado para expressar o critério em termos das tensões principais. 


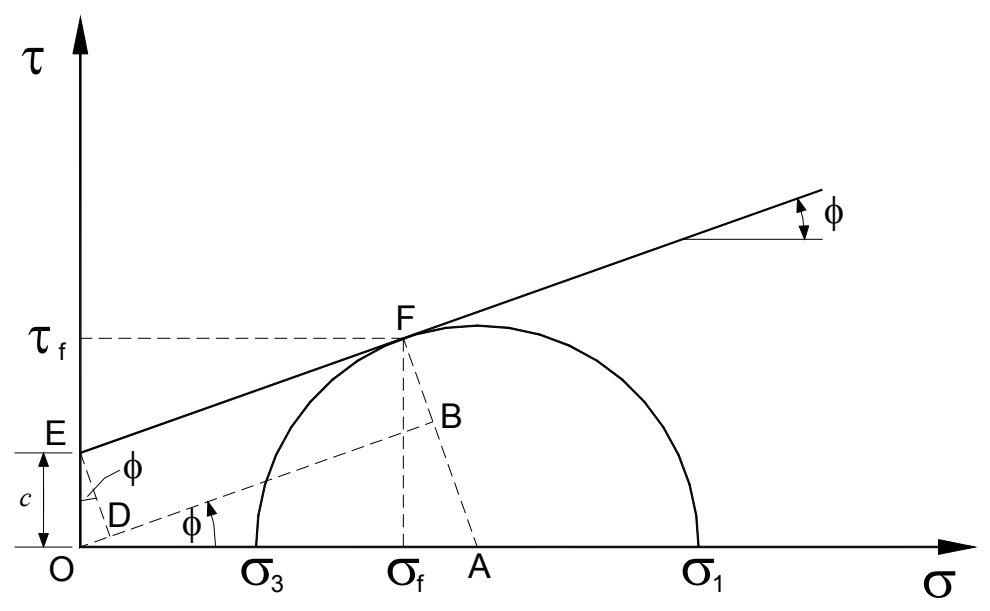

FIGURA 4.3 Critério de ruptura de Mohr-Coulomb.

A partir da FIGURA 4.3, pode-se escrever que:

$$
\frac{\sigma_{1}-\sigma_{3}}{2}=A B+B F
$$

Encontrando os equivalentes de $\mathrm{AB}$ e BF, a EQUAÇÃO 4.12 pode ser escrita na forma seguinte:

$$
\frac{\sigma_{1}-\sigma_{3}}{2}=\frac{\sigma_{1}+\sigma_{3}}{2} \operatorname{sen} \phi+c \cos \phi
$$

Finalmente, o critério de Mohr-Coulomb em termos das tensões principais fica expresso como:

$$
\sigma_{1}=\frac{2 c \cos \phi}{1-\operatorname{sen} \phi}+\frac{1+\operatorname{sen} \phi}{1-\operatorname{sen} \phi} \sigma_{3}
$$

onde:

$\sigma_{1}$ : Tensão principal maior;

$\sigma_{3}:$ Tensão principal menor.

\subsection{Modelo Elasto-Plástico de Mohr-Coulomb}

Baseado na teoria da plasticidade, os modelos são caracterizados por suas funções de plastificação, lei de fluxo e as funções de endurecimento/amolecimento, esta última não existente para o caso de plasticidade perfeita.

Com a finalidade de avaliar se ocorrem ou não deformações irreversíveis, uma função de plastificação, $f$, é introduzida envolvendo tensões e deformações. A função de plastificação pode estar presente como uma superfície no espaço das tensões principais. O modelo perfeitamente plástico é um modelo constitutivo com uma superfície de 
plastificação fixa e definida por parâmetros independentes das deformações plásticas. Para estados de tensões representados por pontos abaixo da superfície de plastificação, o comportamento é puramente elástico quando $f<0$ e todas as deformações são reversíveis. Os pontos sobre a superfície se encontram em estado de plastificação com a condição de $f=0$.

A implementação do modelo elasto-plástico de Mohr-Coulomb no FLAC ${ }^{2 \mathrm{D}}$ está baseada na EQUAÇÃO 4.14. As tensões principais $\sigma_{1}, \sigma_{2}, \sigma_{3}$ são usadas, a tensão fora do plano sendo reconhecida como uma destas tensões (ITASCA, 1995).

Os correspondentes incrementos das deformações principais, $\Delta \varepsilon_{1}, \Delta \varepsilon_{2}, \Delta \varepsilon_{3}$, são decompostos em duas parcelas, como segue:

$$
\Delta \varepsilon_{i}=\Delta \varepsilon_{i}^{e}+\Delta \varepsilon_{i}^{p}, \quad i=1,3
$$

onde os sobrescritos $e$ e $p$ referem-se, respectivamente, às parcelas da deformação elástica e plástica, e a componente plástica não é nula somente durante o fluxo plástico.

\subsubsection{Funções de plastificação e de potencial plástico}

O modelo de Mohr-Coulomb é um modelo elasto-plástico perfeito, com a função de plastificação igual a zero $(f=0)$ na condição de plastificação. O critério de ruptura de Mohr-Coulomb pode ser re-escrito e formulado como uma função de plastificação de cisalhamento, $f^{s}$, e representado pela EQUAÇÃO 4.16, representada no espaço $\left(\sigma_{1}, \sigma_{3}\right)$, como ilustrado na FIGURA 4.4.

$$
f^{s}=\sigma_{1}-\sigma_{3} N_{\phi}-2 c \sqrt{N_{\phi}}
$$

onde:

$$
N_{\phi}=\frac{1+\operatorname{sen} \phi}{1-\operatorname{sen} \phi}
$$

A função de plastificação de tração, $f^{t}$, está definida pela equação seguinte:

$$
f^{t}=\sigma_{t}-\sigma_{3}
$$

onde:

$\sigma_{t}:$ Resistência à tração. 
A função de potencial plástico de cisalhamento, $g^{s}$, corresponde a uma lei de fluxo não associada definida pela EQUAÇÃO 4.19; a função de potencial plástico de tração, $g^{t}$, corresponde a uma lei de fluxo associada e está definida pela EQUAÇÃO 4.20

$$
\begin{aligned}
& g^{s}=\sigma_{1}-\sigma_{3} N_{\psi} \\
& g^{t}=-\sigma_{3}
\end{aligned}
$$

onde:

$$
N_{\psi}=\frac{1+\operatorname{sen} \psi}{1-\operatorname{sen} \psi}
$$

onde:

$\psi$ : Ângulo de dilatância.

A função de potencial plástico também é ilustrada na FIGURA 4.4.
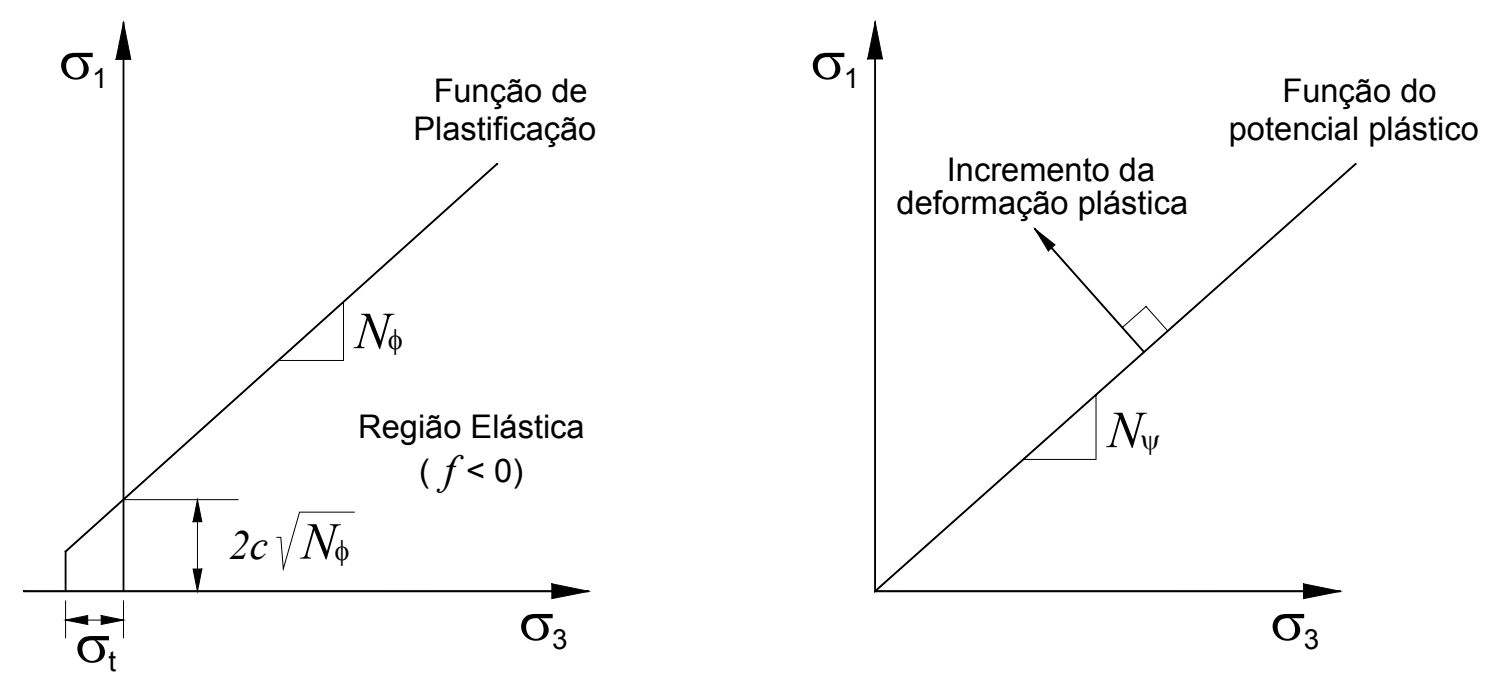

FIGURA 4.4 Funções de plastificação e função de potencial plástico para o modelo elasto-plástico perfeito de Mohr-Coulomb.

\subsubsection{Lei de fluxo}

A lei de fluxo define a magnitude e a orientação dos incrementos da deformação plástica, $\Delta \varepsilon_{p}$, como:

$$
\Delta \varepsilon_{i}^{p}=\lambda \frac{\partial g^{s}}{\partial \sigma_{i}}, \quad i=1,3
$$

em que $\lambda$ é um multiplicador não negativo. 
Para o comportamento puramente elástico, $\lambda$ é zero, e, no caso do comportamento plástico, $\lambda$ é positivo.

Considera-se a lei de fluxo como sendo associada quando a função de plastificação e a função de potencial plástico coincidem (FIGURA 4.5). Caso contrário, a lei é dita não associada. A lei de fluxo associada significa que o ângulo de atrito e o ângulo de dilatância são iguais (FIGURA 4.5). Conforme indica a literatura, para materiais rochosos, o ângulo de atrito é significativamente maior que o ângulo de dilatância, e a lei de fluxo não associada deve ser usada.

Lei de Fluxo Associada

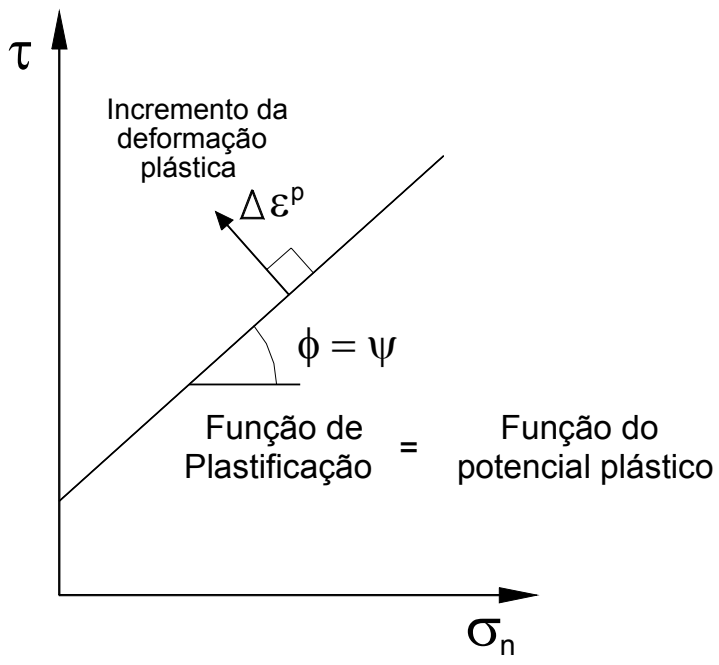

Lei de Fluxo Não-Associada

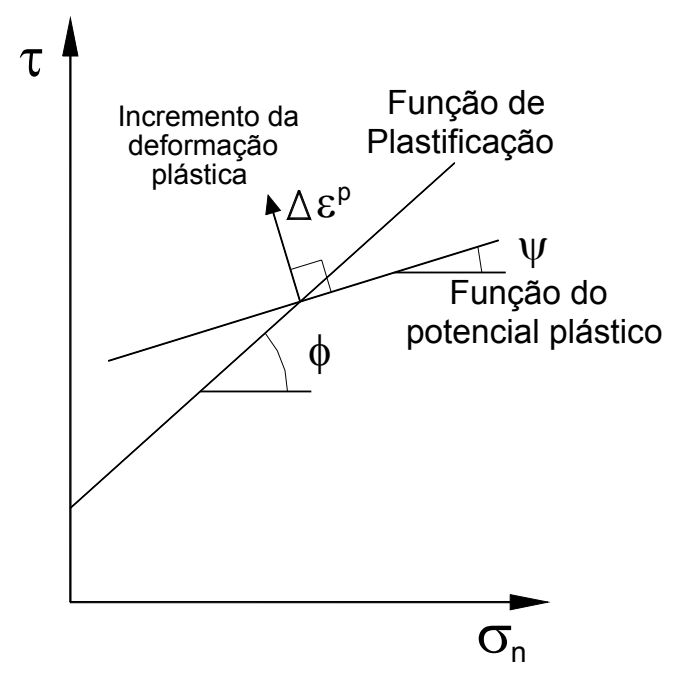

FIGURA 4.5 Leis de fluxo associada e não associada.

\subsection{Modelo de Amolecimento da Coesão e de Endurecimento do Atrito por deformação plástica}

Este modelo está baseado no modelo de Mohr-Coulomb com a lei de fluxo não associada, conforme descrito anteriormente. A diferença está em que os parâmetros de coesão, atrito e dilatância podem sofrer endurecimento ou amolecimento depois do limite de plastificação. Cabe mencionar que, no modelo de Mohr-Coulomb, aqueles parâmetros são assumidos constantes.

O modelo elasto-plástico, em combinação com os critérios de ruptura empíricos como de Mohr-Coulomb e de Hoek-Brown, têm sido aplicados para a análise de rupturas em rochas. Estes critérios assumem que a mobilização das componentes de resistência é simultânea durante o processo de ruptura, levando a resultados pouco realistas em rochas frágeis (HAJIABDOLMAJID, 2001). 
Sabe-se que, segundo o critério de Mohr-Coulomb, a resistência dos geomateriais engloba duas componentes ou parcelas, a resistência coesiva e a resistência ao atrito. Em rochas, onde as deformações irreversíveis estão associadas basicamente ao aparecimento de micro-fissuras, conforme mostrado pelos resultados de ensaios cíclicos de carga e descarga apresentados por MARTIN e CHANDLER (1994), a mobilização das componentes de resistência não é simultânea, isto em particular para rochas duras, quando a ruptura ocorre em ambientes de baixo confinamento. SU et al. (2000) também obtiveram resultados similares. Segundo os resultados dos autores supramencionados, o processo de ruptura corresponderia à perda da resistência coesiva e a mobilização do atrito.

VERMEER e DE BORST (1984) sustentam que o amolecimento da coesão pode ser explicado considerando que, quando um corpo de prova de rocha intacta ou de concreto é submetido a cargas, primeiro se desenvolvem as micro-fissuras, e quando se chega à ruptura propriamente dita, o corpo de prova, se encontra altamente microfissurado. Conseqüentemente, a cimentação decresce gradualmente, e, assim, a resistência coesiva do material desaparece gradualmente.

Conforme os estudos de MARTIN e CHANDLER (1994), pode-se dizer que, em rochas duras, o processo micro-mecânico complexo (micro-fraturamento) precede à formação da superfície de cisalhamento em macro-escala. Os mecanismos de fraturamento por tração induzem dano durante a ruptura da rocha, sendo esta a causa principal ou a responsável pela perda da coesão e a conseqüente mobilização da resistência ao atrito, resultando na mobilização não simultânea das componentes de resistência.

VERMEER e DE BORST (1984) propuseram um modelo de endurecimentoamolecimento para representar materiais granulares soltos e cimentados, onde consideram isotrópico tanto o endurecimento, quanto o amolecimento. PROENÇA (1988) inclui este mesmo modelo para representar o comportamento pós-fratura do concreto sujeito à solicitação de compressão. HAJIABDOLMAJID (2001), a fim de descrever a mobilização não simultânea das componentes de resistência em rochas duras, fez uso do modelo proposto por VERMEER e DE BORST (1984), fazendo algumas variações no modelo original. De forma geral, o modelo de VERMEER e DE BORST (1984) considera a perda da resistência coesiva e o ganho do atrito em função das deformações plásticas. 
A característica do modelo de VERMEER e DE BORST (1984) é que, por considerar o fenômeno da dilatância, ele está formulado com base na lei de fluxo não associada. Outra característica do modelo é associar a evolução das superfícies de plastificação e de potencial plástico (escritas numa forma idêntica à superfície de MohrCoulomb) com a variação de parâmetros do material como o ângulo de atrito e a coesão. Segundo este modelo, a variação do ângulo de atrito reproduz o endurecimento, ao passo que a da coesão reproduz o amolecimento.

Neste modelo, os parâmetros de $c_{m o b}$ e $\phi_{m o b}$ são o ângulo de atrito e a coesão mobilizados, os quais, de modo geral, podem ser expressos em função da deformação plástica efetiva, $\bar{\varepsilon}^{p}$, mediante relações empíricas apresentadas nas EQUAÇÕES $4.23 \mathrm{e}$ 4.24 .

$$
\begin{aligned}
& c_{m o b}=c_{i} \cdot \exp \left[-\left(2 \frac{\bar{\varepsilon}^{p}}{\varepsilon_{c}^{p}}\right)^{2}\right] \\
& \operatorname{sen} \phi_{m o b}=\left\{\begin{array}{lll}
2 \frac{\sqrt{\bar{\varepsilon}^{p} \varepsilon_{f}^{p}}}{\bar{\varepsilon}^{p}+\varepsilon_{f}^{p}} \operatorname{sen} \phi & p / \bar{\varepsilon}^{p} \leq \varepsilon_{f}^{p} \\
\operatorname{sen} \phi & p / \bar{\varepsilon}^{p}>\varepsilon_{f}^{p}
\end{array}\right\}
\end{aligned}
$$

onde:

$\varepsilon_{c}^{p}$ : Deformação plástica requerida para a perda da coesão;

$\varepsilon_{f}^{p}$ : Deformação plástica na qual o atrito não sofre mais variações;

$c_{i}$ : Coesão inicial ou de pico;

$\phi$ : Máximo valor do ângulo de atrito.

Nestas funções, na medida em que a coesão entre os grãos decresce, o atrito sofre um acréscimo. Assim, $\phi_{m o b}$ se apresenta numa forma crescente com a deformação plástica. A FIGURA 4.6 ilustra graficamente as EQUAÇÕES 4.23 e 4.24 adotadas para a variação do ângulo de atrito e a coesão. 

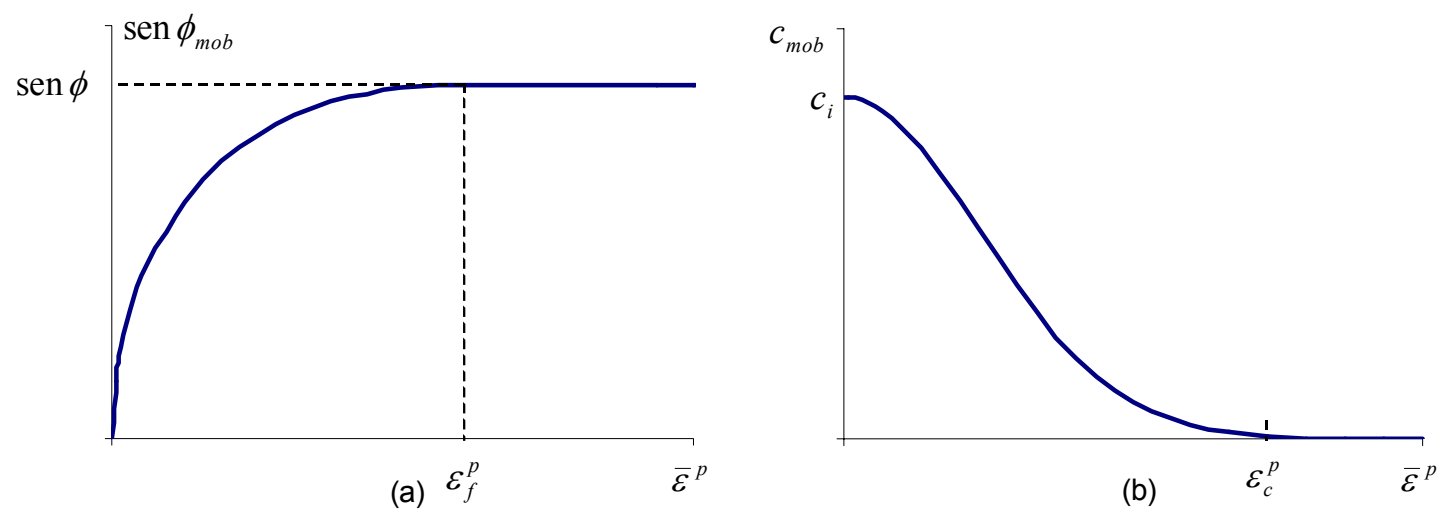

FIGURA 4.6 Funções empíricas para: (a) Endurecimento do atrito e (b) Amolecimento da coesão (VERMEER e DE BORST, 1984).

HAJIABDOLMAJID (2001), adotou uma modificação do modelo de Mohr-Coulomb para levar em consideração a mobilização não simultânea das componentes de resistência. Segundo aquele autor, a resistência ao cisalhamento fica expressa como:

$$
\tau^{*}=c_{\left(\bar{\varepsilon}^{p}\right)}+\sigma_{n\left(\bar{\varepsilon}^{p}\right)} \tan \phi
$$

onde a resistência ao cisalhamento mobilizada, $\tau^{*}$, é igual à resistência coesiva mobilizada mais a resistência ao atrito mobilizada. Na EQUAÇÃO 4.25, tanto a coesão, como a tensão normal são dependentes da deformação plástica efetiva , $\bar{\varepsilon}^{p}$, que é um parâmetro de amolecimento-endurecimento.

No presente trabalho, o modelo de amolecimento da coesão e de endurecimento do atrito por deformações plásticas está baseado nas relações quase-empíricas propostas por VERMEER e DE BORST (1984), sendo feitas algumas mudanças nas equações propostas por aqueles autores com a finalidade de representar os mecanismos de ruptura. O modelo está baseado no critério de Mohr-Coulomb com a função do potencial plástico correspondente à lei de fluxo não associada e com a função do potencial plástico de tração correspondente à lei de fluxo associada.

\subsubsection{Amolecimento da Coesão por deformação plástica}

O processo de amolecimento da coesão de pico $\left(c_{i}\right)$ deve representar a perda da resistência coesiva devido ao acúmulo de dano na rocha (crescimento de micro-fissuras). Assim, a resistência coesiva diminui gradualmente com o acréscimo do dano ou pela deformação plástica. HAJIABDOLMAJID (2001) sustenta que, em situações práticas e em alguns tipos de rochas, a quantidade da deformação plástica necessária para consumir 
toda a resistência coesiva pode ser muito grande, o que seria impossível em um sistema de carregamento real. Assim, pode ser razoável estabilizar a resistência coesiva num certo nível residual $\left(c_{r}\right)$. Uma aproximação da perda da resistência coesiva em função da deformação plástica (dano) pode ser expressa pela EQUAÇÃO 4.23, a qual é modificada para levar a uma resistência coesiva residual diferente de zero:

$$
c_{\text {mob }}=\left(c_{i}-c_{r}\right) \cdot \exp \left[-\left(2 \frac{\bar{\varepsilon}^{p}}{\varepsilon_{c}^{p}}\right)^{2}\right]+c_{r}
$$

onde $\varepsilon_{c}^{p}$ é a deformação plástica requerida para atingir à coesão residual, que seria uma constante do material no modelo adotado. Na FIGURA 4.7, apresentam-se graficamente as aproximações para o amolecimento da resistência coesiva segundo a EQUAÇÃO 4.23, com coesão residual de zero, e EQUAÇÃO 4.26, com coesão residual diferente de zero.
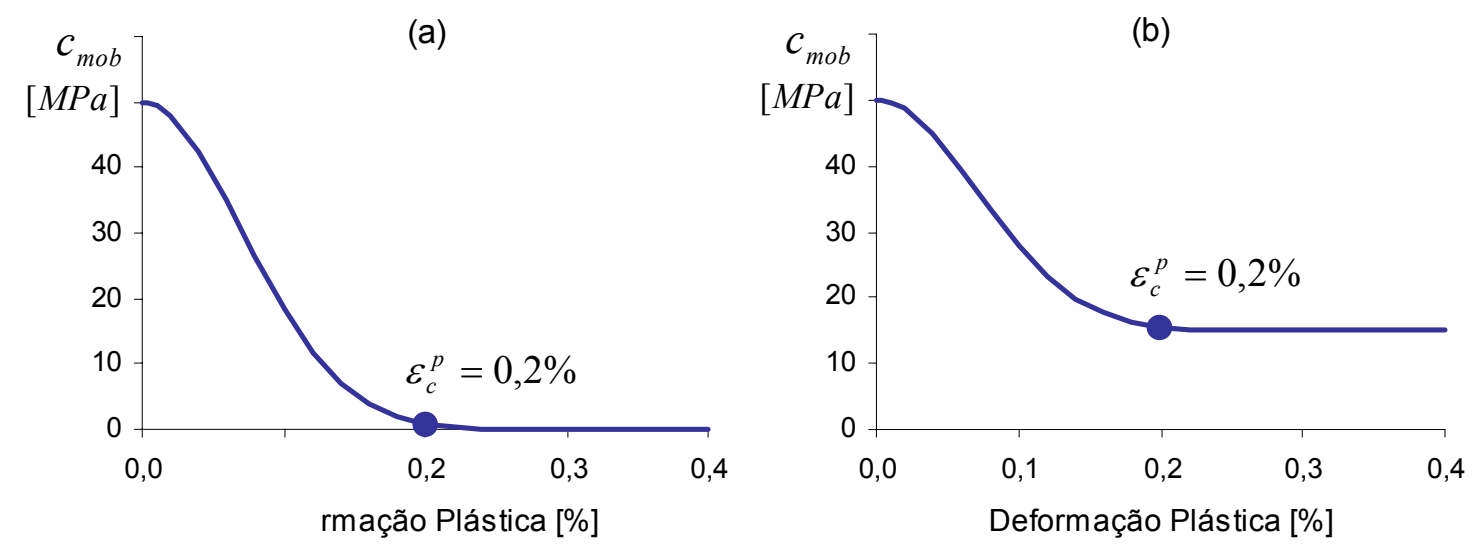

FIGURA 4.7 Aproximação exponencial para o amolecimento da resistência coesiva, (a) EQUAÇÃO 4.23, (b) EQUAÇÃO 4.26.

\subsubsection{Endurecimento do atrito por deformação plástica}

A EQUAÇÃO 4.24 dá uma idéia da mobilização do atrito em função da deformação plástica. HAJIABDOLMAJID (2001) adaptou estas funções para casos mais gerais e para considerar materiais menos frágeis, conforme a equação seguinte:

$$
S_{m o b}=\left\{\begin{array}{lll}
\left(\sigma_{n o}+2 \frac{\sqrt{\bar{\varepsilon}^{p} \varepsilon_{f}^{p}}}{\bar{\varepsilon}^{p}+\varepsilon_{f}^{p}} \sigma_{n}\right) \tan \phi & p / \bar{\varepsilon}^{p} \leq \varepsilon_{f}^{p} \\
\sigma_{n} \tan \phi & p / \bar{\varepsilon}^{p}>\varepsilon_{f}^{p}
\end{array}\right\}
$$

onde, $s_{\text {mob }}$ representa à resistência ao atrito mobilizado; $\sigma_{n o} \tan \phi$ representa a resistência ao atrito mobilizado inicial e $\varepsilon_{f}^{p}$ é a deformação plástica requerida para que o 
atrito $(\phi)$ atinja a sua máxima mobilização. Nota-se que, na EQUAÇÃO 4.27, a tensão normal é dependente da deformação plástica efetiva.

Considerando a dependência do ângulo de atrito das deformações plásticas, a EQUAÇÃO 4.24 pode ser modificada da seguinte forma:

$$
\operatorname{sen} \phi_{m o b}=\left\{\begin{array}{lll}
2 \frac{\sqrt{\bar{\varepsilon}^{p} \varepsilon_{f}^{p}}}{\bar{\varepsilon}^{p}+\varepsilon_{f}^{p}}\left(\operatorname{sen} \phi-\operatorname{sen} \phi_{o}\right)+\operatorname{sen} \phi_{o} & p / & \bar{\varepsilon}^{p} \leq \varepsilon_{f}^{p} \\
\operatorname{sen} \phi & p / & \bar{\varepsilon}^{p}>\varepsilon_{f}^{p}
\end{array}\right\} 4.28
$$

onde $\phi_{m o b}$ representa o ângulo de atrito mobilizado como na EQUAÇÃO 4.24, $\phi_{o}$ é o atrito mobilizado inicial, o qual seria equivalente à resistência ao atrito mobilizada inicial, $\sigma_{n o} \tan \phi ; \phi$ é o ângulo de atrito mobilizado máximo e $\varepsilon_{f}^{p}$ é a deformação plástica requerida para que o atrito atinja a sua máxima mobilização, a qual seria uma constante do material no modelo adotado. A EQUAÇÃO 4.28 seria basicamente uma simples modificação da EQUAÇÃO 4.24, com a diferença de que esta equação considera o atrito mobilizado inicial, $\phi_{o}$. A representação gráfica da EQUAÇÃO 4.28 está na FIGURA 4.8 para o caso a, com $\phi_{o}=0$, e para o caso b, com $\phi_{o}=10$.
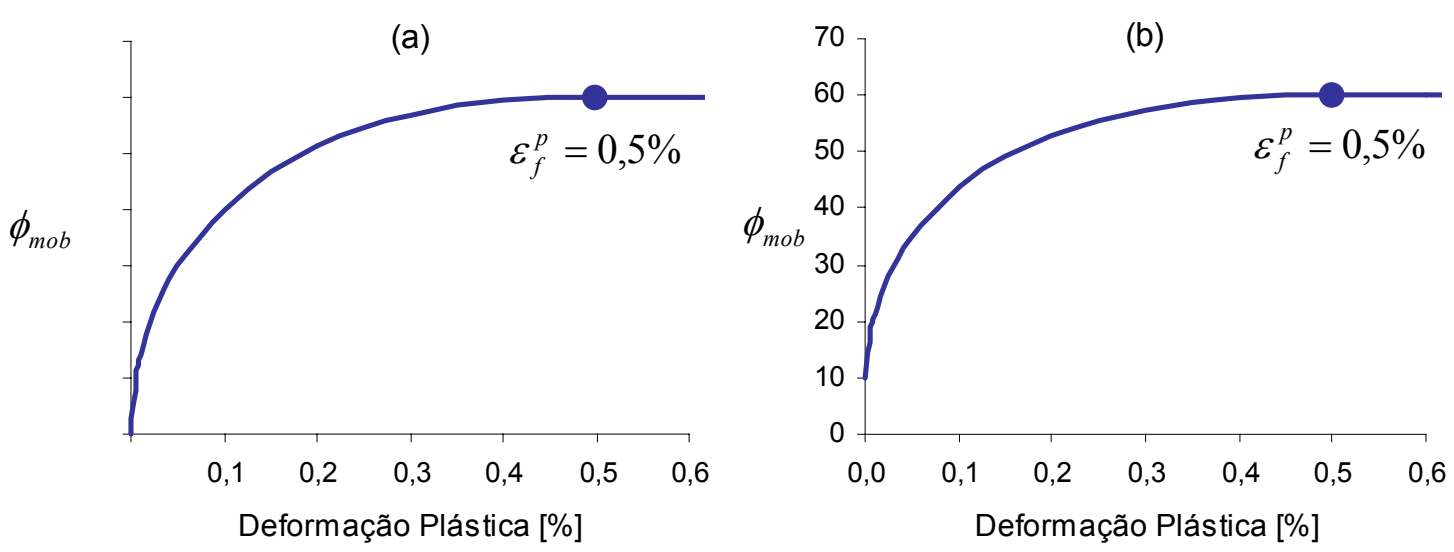

FIGURA 4.8 Aproximação para o endurecimento do atrito, EQUAÇÃO 4.18: (a) $\phi_{o}=0$, (b) $\phi_{o}=10$.

A EQUAÇÃO 4.28 supõe que o atrito é mobilizado em função da deformação plástica desde um ângulo de atrito igual a $\phi_{o}$ até o valor máximo do atrito, sendo $\varepsilon_{f}^{p}$ a deformação plástica necessária para a máxima mobilização do atrito. Através da EQUAÇÃO 4.28, consegue-se representar adequadamente o endurecimento do atrito. 
Por outro lado, o início do comportamento de endurecimento é gradual e não está claramente definido. Segundo VERMEER e DE BORST (1984), neste estágio do ensaio, a deformação chega a ser cada vez mais inelástica devido ao micro-fraturamento do concreto e das rochas e devido ao deslizamento entre partículas no solo. Este fenômeno é causado pelo deslizamento friccional entre as partículas de solo ou ao longo de microfissuras nas rochas e no concreto (FIGURA 4.9).

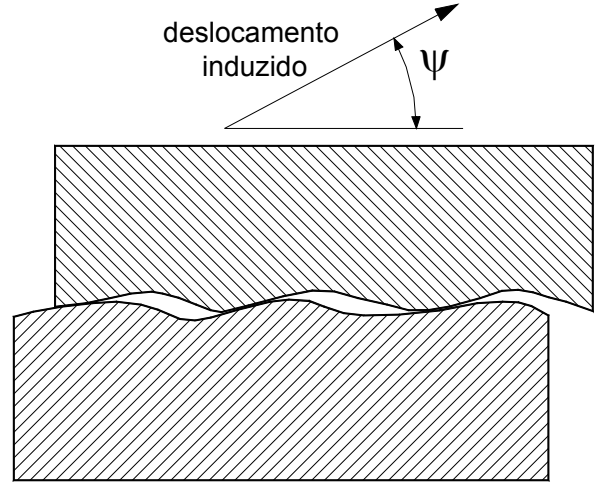

a) Material cimentado

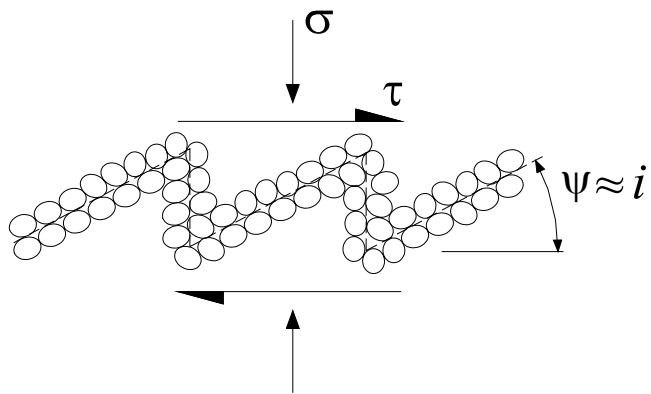

b) Material granular

FIGURA 4.9 (a) Deslizamentos em micro-fissuras (VERMEER e DE BORST, 1984), e (b) deslizamentos entre grupos de partículas (WODD, 1990), ambos originam dilatância.

A explicação e o prognóstico da resistência de juntas rugosas parecem ter sido baseados na observação do comportamento de dilatância de materiais granulares como a areia. Uma analogia simples da dilatância em solos é explicada por dentes de serra representando o intertravamento, como mostrado na FIGURA 4.9. Assim, o solo compacto sofre expansão quando é submetido a cisalhamento e é assumido que o deslizamento não se dá em planos horizontais, mas sim em planos inclinados, num ângulo de dilatância, $\psi$, em relação à direção da força de cisalhamento aplicada. Nos planos inclinados, ocorrem deslizamentos entre as partículas de solo (WOOD, 1990). NEWLAND e ALLELY (1957) propuseram uma equação para representar a resistência ao cisalhamento máximo $\left(s_{p}\right)$ de materiais granulares quando submetidos a uma tensão normal $\left(\sigma_{n}\right)$, da forma seguinte:

$$
s_{p}=\sigma_{n} \tan \left(\phi_{b}+i\right)
$$

onde o ângulo $i$ é o ângulo médio de desvio formado entre as direções dos deslocamentos das partículas (ângulo de dilatância, $\psi$ ) e a direção da força de cisalhamento aplicada (FIGURA 4.9), e $\phi_{b}$ é o ângulo de atrito entre as partículas. PATTON (1966) também fez uso da EQUAÇÃO 4.29 para representar a resistência ao 
cisalhamento de juntas irregulares quando ensaiadas em baixas tensões normais. As componentes $\phi_{b}$ e $i$ da EQUAÇÃO 4.29 são usualmente denominadas como o ângulo de atrito básico e de rugosidade efetiva.

Para materiais como a areia densa, quando submetida a cisalhamento, o solo sofre expansão por causa do intertravamento entre as partículas. Assim, a deformação pode ocorrer somente se as partículas puderem montar umas sobre as outras. Segundo WOOD (1990), quando as partículas sofrem deslizamentos e rotação de tal modo que o volume do solo permanece constante, o solo atingiu a seu estado critico. Nestas condições, a dilatância é zero $(\psi=0$ ) e a relação $q / p=\mu$, ( $q$ é a carga de cisalhamento, e $p$ é a carga normal). Para esta condição, aquele autor formula que o atrito mobilizado no plano horizontal é igual a:

$$
\tan \phi_{m o b}=\mu+\tan \psi
$$

Na FIGURA 4.10, apresentam-se os resultados de ensaios de cisalhamento direto em areias densas e fofas reportadas por TAYLOR (1948) e re-analisadas por WOOD (1990) à luz da EQUAÇÃO 4.30.
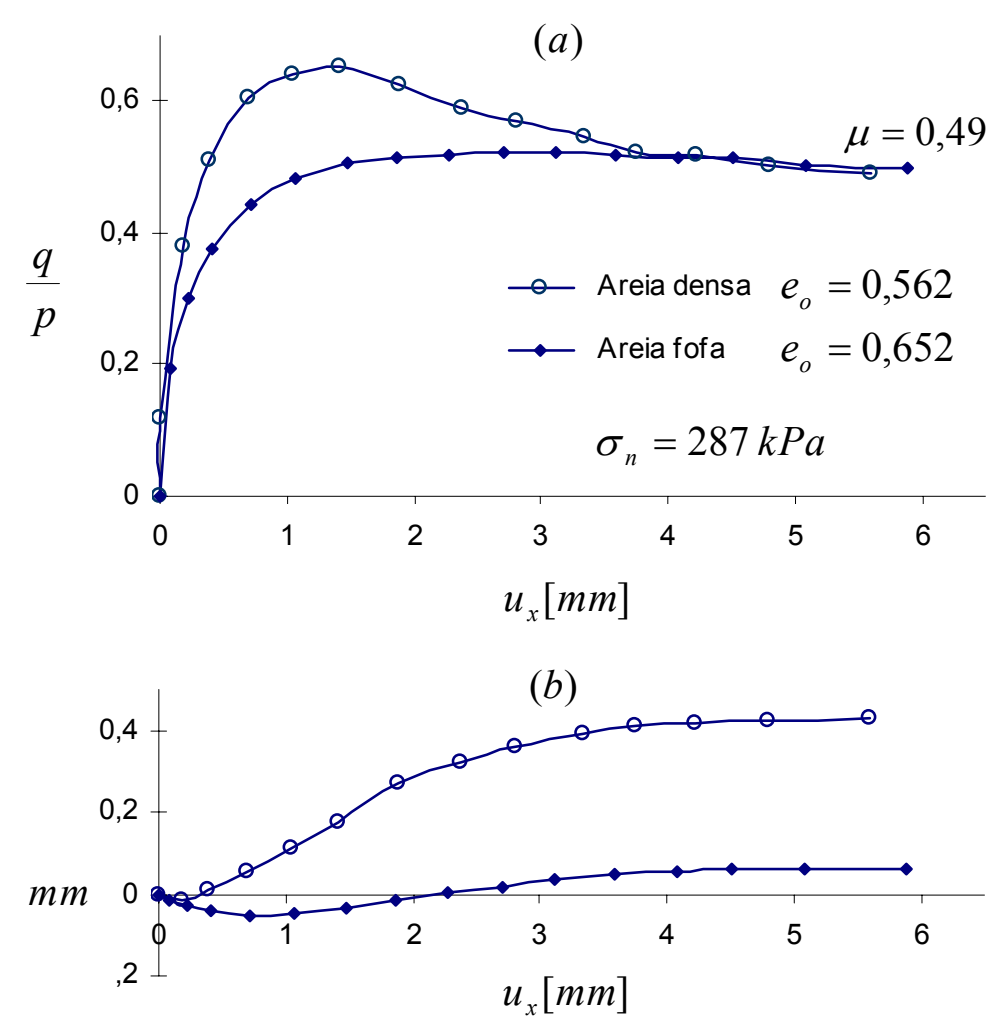

FIGURA 4.10 Ensaio de cisalhamento direto da areia Ottawa: (a) atrito mobilizado no plano horizontal $(q / p)$ versus deslocamento horizontal $\left(u_{x}\right) ; \quad$ (b) deslocamento vertical $\left(u_{y}\right)$ versus deslocamento horizontal (WOOD, 1990). 
Conforme mostrado na FIGURA 4.10, as areias densas têm um considerável grau de intertravamento entre as partículas e, antes de acontecer ruptura por cisalhamento, este intertravamento deve ser superado adicionalmente à resistência friccional básica nos pontos de contacto entre as partículas. O grau de intertravamento será muito maior no caso de areias muito densas. Nestas condições, a curva atrito mobilizado $(q / p)$ versus deslocamento horizontal $\left(u_{x}\right)$ apresenta uma pico associado a um deslocamento relativamente baixo e logo depois, o intertravamento é progressivamente superado; assim, a força cisalhante necessária para um deslocamento adicional diminui. A diminuição do grau de intertravamento produz um acréscimo de volume durante o cisalhamento. $O$ termo dilatância é usado para descrever o acréscimo de volume nas areias densas durante o cisalhamento. O plano de cisalhamento macroscópico é horizontal, mas o deslizamento entre as partículas individuais se dá sobre numerosos planos microscópicos inclinados (FIGURA 4.9) ao longo dos quais ocorrem deslizamentos entre as partículas vizinhas. No caso das areias fofas, como não há um intertravamento significativo, a tensão incrementa gradualmente para um valor último sem um pico. O acréscimo da tensão está acompanhado por um leve decréscimo de volume.

BARTON $(1973,1976)$ estudou o comportamento de juntas de rochas naturais, e para a estimativa da resistência ao cisalhamento de pico das juntas propôs que a EQUAÇÃO 4.29 pode ser re-escrita como:

$$
s_{p}=\sigma_{n} \tan \left(\phi_{b}+J R C \log \left(\frac{J C S}{\sigma_{n}}\right)\right)
$$

onde:

$J R C$ : Coeficiente de rugosidade da junta;

$J C S$ : Resistência à compressão da parede da junta;

$\phi_{b}:$ Ângulo de atrito básico.

BARTON e CHOUBEY (1977) modificaram a EQUAÇÃO 4.31, conforme abaixo:

$$
s_{p}=\sigma_{n} \tan \left(\phi_{r}+J R C \log \left(\frac{J C S}{\sigma_{n}}\right)\right)
$$

onde, $\phi_{r}$ é o ângulo de atrito residual

Tanto o atrito básico, $\phi_{b}$, como o atrito residual, $\phi_{r}$, representam as resistências mínimas de cisalhamento. Conceitualmente, $\phi_{b}$ refere-se às superfícies planas e lisas em 
rocha fresca e pode ser considerado como constante do material. Contudo, $\phi_{r}$ refere-se à condição residual das superfícies de juntas naturais, que é atingida só depois de grandes deslocamentos de cisalhamento. A estimativa de $\phi_{r}$ é difícil devido ao fato que grandes deslocamentos são requeridos.

Na EQUAÇÃO 4.31, de forma conveniente, o atrito de pico, $\phi_{p}$, pode ser expresso em termos de suas componentes (BARTON e BANDIS, 1982 e BARTON et al., 1985):

$$
\phi_{p}=\phi_{r}+J R C \log \left(\frac{J C S}{\sigma_{n}}\right)
$$

Nesta equação, a parcela devida à rugosidade pode estar representada por:

$$
i=J R C \log \left(\frac{J C S}{\sigma_{n}}\right)
$$

A resistência de pico é mobilizada com um certo deslocamento de cisalhamento, $\delta_{p}$, o qual é conhecido como deslocamento de pico, onde o $\delta_{p}$ é freqüentemente igual a $1 \%$ do comprimento da junta, $L$, que no caso de tamanhos de amostras de laboratório é adotada como $L_{o}=100 \mathrm{~mm}$. Assim, durante o primeiro milímetro de deslocamento de cisalhamento, $\phi_{r}$ é mobilizado primeiro e em seguida a rugosidade ocasiona dilatância. No comportamento pós-pico, a rugosidade é gradualmente destruída ou sofre uma degradação com o acréscimo dos deslocamentos de cisalhamento; em conseqüência, a dilatância tende a diminuir (BARTON e BANDIS, 1982).

Generalizando a EQUAÇÃO 4.32, o atrito mobilizado pode ser representado para um certo deslocamento $(\delta)$ como:

$$
\phi_{m o b}=\phi_{r}+J R C_{m o b} \log \left(\frac{J C S}{\sigma_{n}}\right)
$$

Juntando as EQUAÇÕES 4.32 e 4.34, obtém -se:

$$
\frac{J R C_{m o b}}{J R C_{p}}=\frac{\phi_{m o b}-\phi_{r}}{\phi_{p}-\phi_{r}}
$$

BARTON et al. (1985) mostram graficamente a mobilização do atrito em função das coordenadas adimensionalisadas $J R C_{m o b} / J R C_{p}$ (EQUAÇÃO 4.35) e de $\delta / \delta_{p}$, conforme a FIGURA 4.11. 


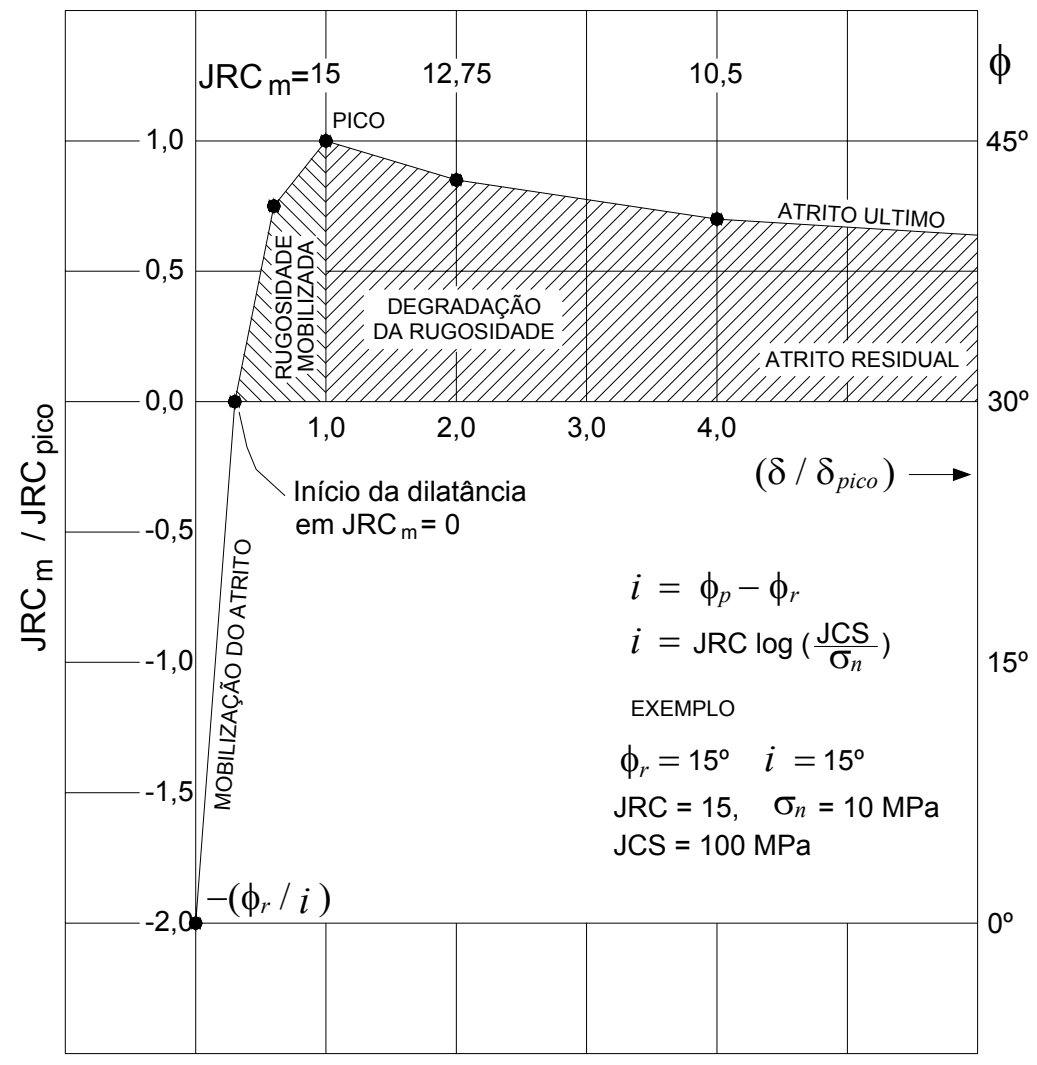

FIGURA 4.11 Modelo adimensional do comportamento de cisalhamento de juntas (Apud. BARTON et al., 1985).

O modelo tensão de cisalhamento-deslocamento está baseado no conceito da rugosidade mobilizada, $J R C_{m o b}$, conforme a formulação adimensional da EQUAÇÃO 4.35. O modelo considera vários aspectos de comportamento na ordem em que eles acontecem durante o cisalhamento, os quais são (BARTON et al., 1985): (i) o atrito é mobilizado imediatamente no início do cisalhamento; (ii) a dilatância se inicia quando a rugosidade é mobilizada; (iii) a resistência de pico é atingida quando $J R C_{m o b} / J R C_{p}=1$; (iv) a dilatância diminui quando a rugosidade é degradada; e (v) a resistência residual é finalmente atingida só depois de grandes deslocamentos.

Conforme discutido anteriormente, o intertravamento para o caso das areias densas, representado por $\tan \psi$ (dilatância) por WOOD (1990), por $i$ por NEWLAND e ALLELY (1957), e a rugosidade representada por $J R C_{p}$ para o caso das juntas rochosas (BARTON et al., 1985) representam parcelas de resistência ao atrito. Com a máxima mobilização das componentes de intertravamento ( $\tan \psi$ ou $i$ ) e de rugosidade $\left(J R C_{p}\right)$, é atingida a resistência ao atrito de pico $\left(s_{p}\right)$; desta forma, elas são consideradas como uma parcela da resistência ao atrito. 
Conforme as FIGURAS 4.10 e 4.11, uma vez atingida a resistência ao atrito de pico, ela começa a sofrer um decréscimo, isto devido ao fato que o intertravamento e a rugosidade são superados, de modo que a força de cisalhamento necessária para causar deslocamentos adicionais diminui. Na região pós-pico, para ambos os casos, claramente apresenta-se uma degradação tanto do intertravamento, como da rugosidade.

Na FIGURA 4.12, apresenta-se a evolução do ângulo de atrito para um corpo de prova cilíndrico do granito Lac du Bonnet quando submetido a carregamentos cíclicos. Conforme discutido anteriormente, consegue-se explicar que a mobilização da resistência ao atrito no corpo de prova de rocha está associada ao micro-fraturamento ou dano induzido por micro-fissuras (MARTIN, 1993 e MARTIN e CHANDLER, 1994).

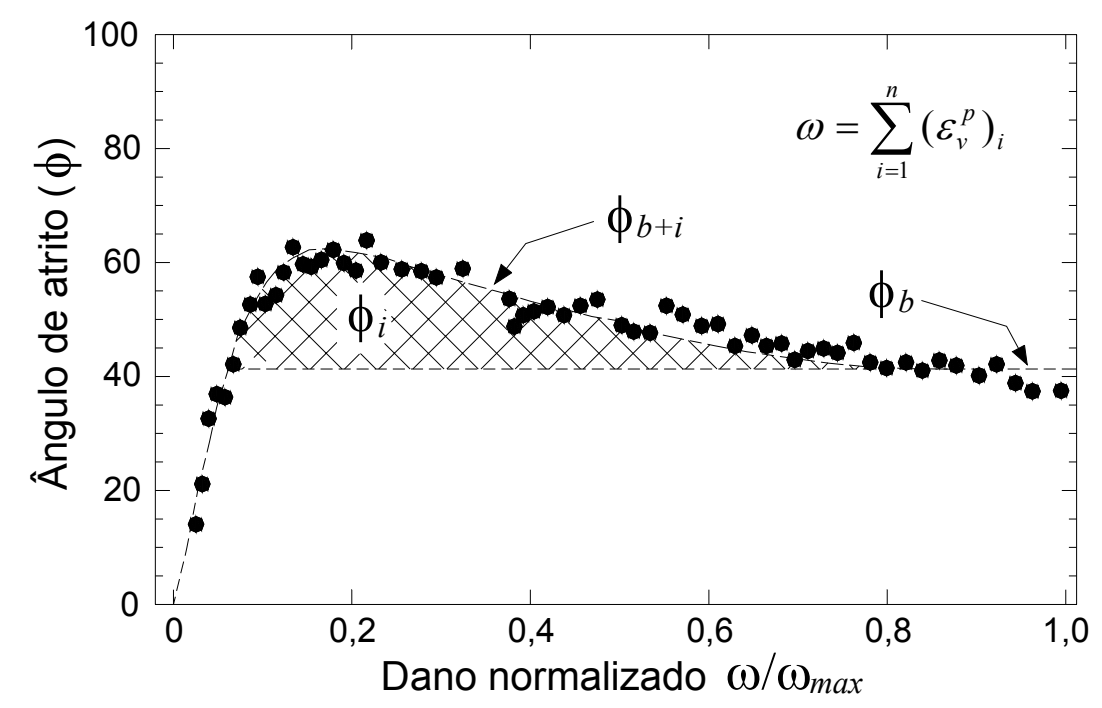

FIGURA 4.12 Evolução do ângulo de atrito total versus o dano normalizado em relação ao dano máximo para uma amostra submetida a carregamentos cíclicos (MARTIN e CHANDLER, 1994).

Conforme discutido por MARTIN e CHANDLER (1994), para o caso do Granito Lac du Bonnet, o atrito total é composto por duas componentes, a saber, pelo atrito básico, $\phi_{b}$, e pela componente devida ao intertravamento e à rugosidade, $\phi_{i}$, de tal forma que o atrito total pode ser expresso como $\phi_{b+i}$. Na FIGURA 4.12, fica evidenciado claramente que o ângulo de atrito total é mobilizado até o seu valor de pico com um determinado nível de dano, e que logo depois o ângulo de atrito total começa a diminuir em função do acréscimo do dano.

Denomina-se como $\phi^{*}$ à variação do ângulo de atrito total durante o processo de ruptura, composta pelas parcelas de $\phi_{b}$ e de $\phi_{i}$. Baseado nas FIGURAS 4.10, $4.11 \mathrm{e}$ 
4.12, a evolução do atrito total durante o processo da ruptura sugere que o comportamento é dividido em duas fases: (a) mobilização, e (b) degradação do atrito, conforme se mostra na FIGURA 4.13.

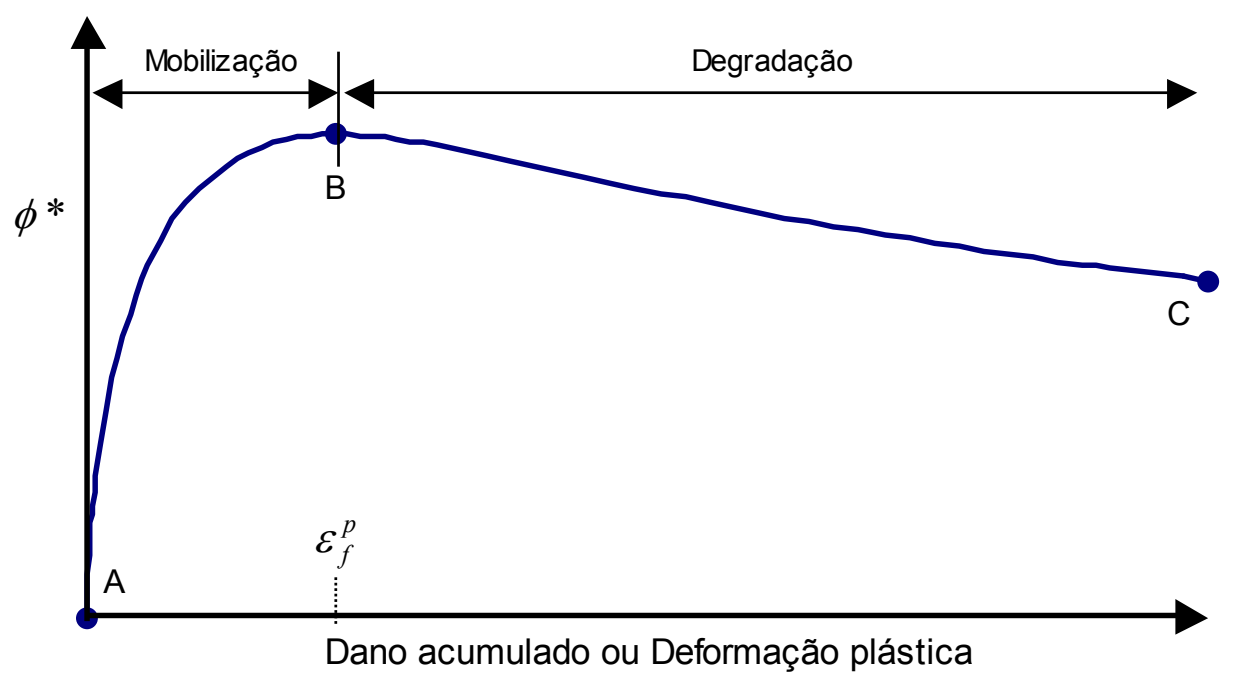

FIGURA 4.13 Evolução do atrito total durante o processo de ruptura: mobilização e degradação.

A mobilização do atrito total é descrita pela curva $A B$ na qual o atrito total se mobiliza em função do dano ou das deformações plásticas no corpo de prova ou em função dos deslocamentos de cisalhamento nos ensaios de cisalhamento direto. O ângulo de atrito total atinge a sua máxima mobilização com um certo nível de dano ou deformação plástica, $\varepsilon_{f}^{p}$, ou com um certo deslocamento de cisalhamento, $\delta_{p}$. A degradação do atrito é descrita pela curva BC. O atrito total se degrada com o acúmulo do dano ou com os deslocamentos adicionais, assim, atingindo um valor residual, $\phi_{r}$, onde o ângulo de atrito não teria mudanças significativas com o acréscimo do dano ou deslocamentos adicionais.

Com fins de representar o mecanismo ou a evolução do atrito conforme resumido na FIGURA 4.13, uma equação matemática em função da deformação plástica (dano) deve ser ajustada. A EQUAÇÃO 4.28 foi usada como base para representar a mobilização do atrito total (curva $A B$, Figura 4.13) e foi introduzida uma nova função matemática dependente das deformações plásticas para representar a degradação do atrito (curva BC, Figura 4.13). 
A EQUAÇÃO 4.36 representa a mobilização do atrito total, e esta equação é válida quando $\bar{\varepsilon}^{p} \leq \varepsilon_{f}^{p}$ :

$$
\operatorname{sen} \phi^{*}=2 \frac{\sqrt{\bar{\varepsilon}^{p} \varepsilon_{f}^{p}}}{\bar{\varepsilon}^{p}+\varepsilon_{f}^{p}}\left(\operatorname{sen} \phi-\operatorname{sen} \phi_{o}\right)+\operatorname{sen} \phi_{o}
$$

A EQUAÇÃO 4.37 representa a degradação do atrito total, válida quando $\bar{\varepsilon}^{p}>\varepsilon_{f}^{p}$ :

$$
\operatorname{sen} \phi^{*}=2 \frac{\sqrt{\bar{\varepsilon}^{p} \varepsilon_{f}^{p}}}{\bar{\varepsilon}^{p}+\varepsilon_{f}^{p}}\left(\operatorname{sen} \phi-\operatorname{sen} \phi_{r}\right) \cdot \exp \left[-\kappa\left(\varepsilon^{p}-\varepsilon_{f}^{p}\right)\right]+\operatorname{sen} \phi_{r} \quad 4.37
$$

$\phi^{*}$ nas equações 4.36 e 4.37 representa a mobilização e a degradação do ângulo de atrito total $\left(\phi_{b}+\phi_{i}\right), \phi_{o}$ é o atrito mobilizado inicial, $\phi$ é o atrito mobilizado máximo ou o atrito de pico, $\phi_{r}$ é o atrito residual e $\varepsilon_{f}^{p}$ é a deformação plástica requerida para que o atrito total atinja a sua máxima mobilização, após a qual se inicia a degradação. Esta deformação plástica seria uma constante do material no modelo adotado. A constante adimensional $\kappa$, introduzida na EQUAÇÃO 4.37, simula a forma da curva da degradação do atrito no comportamento de pós-pico. Esta constante deve ser calibrada com dados experimentais. Na FIGURA 4.14, mostra-se um exemplo da evolução (mobilização e degradação) do atrito total, onde se mostra graficamente a influência da constante $\kappa$ na forma da curva de degradação. No exemplo, as duas curvas foram geradas com os mesmos valores de atrito de pico e residual.

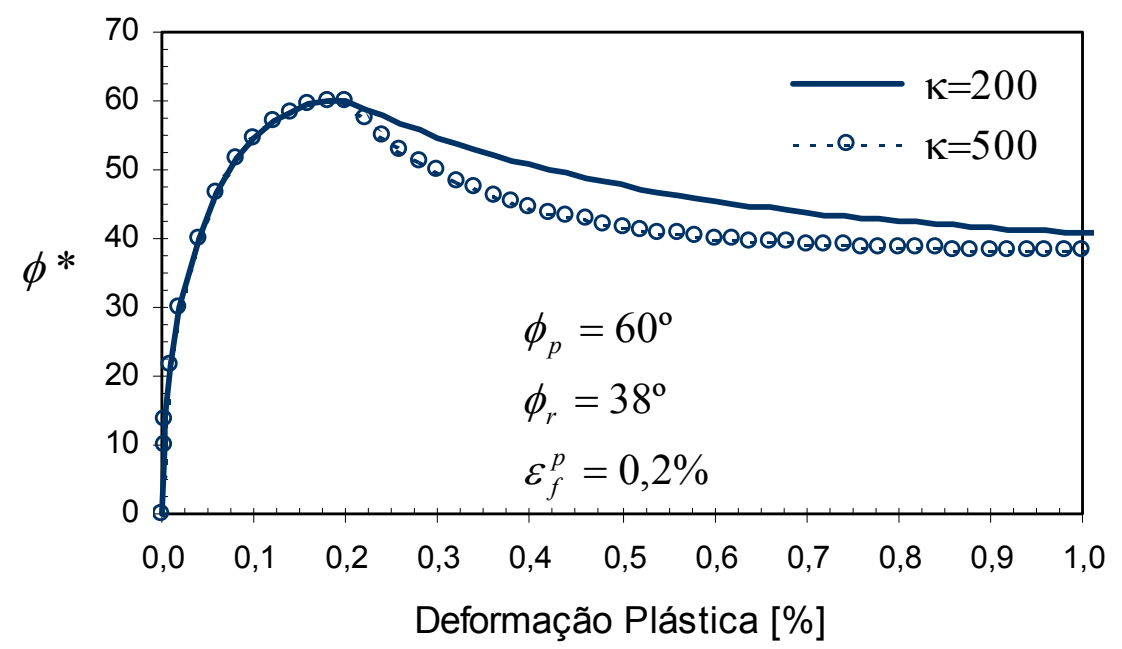

FIGURA 4.14 Exemplo mostrando a variação da forma da curva de degradação em função da constante $\kappa$. 
Conforme anteriormente discutido, parece que o modelo de amolecimento da coesão e de endurecimento do atrito por deformação plástica representa os mecanismos envolvidos durante o processo de ruptura. Em resumo, a perda da resistência coesiva é representada pela EQUAÇÃO 4.26, que considera uma resistência coesiva residual diferente de zero. A mobilização e a degradação do atrito total são representadas pelas EQUAÇÕES 4.36 e 4.37, respectivamente. De forma geral, a resistência coesiva e o atrito total estão expressos em função das deformações plásticas efetivas (dano). No modelo de amolecimento da coesão e de endurecimento do atrito por deformação plástica, a resistência global pode ser expressa como:

$$
\tau^{*}=c_{\left(\bar{\varepsilon}^{p}\right)}+\sigma_{n} \tan \phi_{\left(\bar{\varepsilon}^{p}\right)}^{*}
$$

Onde, $\tau^{*}$ é a resistência ao cisalhamento mobilizada e é igual à resistência coesiva mobilizada mais a resistência ao atrito mobilizada, sendo tanto a coesão, como o ângulo de atrito total dependentes da deformação plástica efetiva (dano), $\bar{\varepsilon}^{p}$.

Com a finalidade de verificar os mecanismos de ruptura através da modelagem numérica conforme o modelo de amolecimento da coesão e de endurecimento do atrito por deformação plástica, foram implementadas as EQUAÇÕES 4.26, 4.36 e 4.37 como subrotinas no modelo original de Mohr-Coulomb no programa FLAC $^{2 \mathrm{D}}$ versão 3.3.

Foi simulado o comportamento mecânico do Granito Lac du Bonnet com o modelo de amolecimento da coesão e de endurecimento do atrito por deformação plástica. A simulação consistiu em verificar os mecanismos que acontecem num corpo de prova quando submetido a um sistema de carregamento, no caso, um ensaio de compressão simples.

Os parâmetros de entrada para o modelo adotado na modelagem numérica foram obtidas a partir de resultados experimentais de ensaios cíclicos (Capítulo 3, Figura 3.5) do granito Lac du Bonnet, conforme apresentados por MARTIN (1993) e MARTIN e CHANDLER (1994). As funções que representam a perda da coesão, a mobilização e a degradação do atrito total foram ajustadas a estes resultados experimentais.

Na FIGURA 4.15, ilustra-se a perda da resistência coesiva do Granito Lac du Bonnet em função da deformação plástica efetiva, $\bar{\varepsilon}^{p}$. Os resultados experimentais são razoavelmente representados pela EQUAÇÃO 4.26, onde a resistência coesiva atinge seu valor residual ou a máxima perda de coesão associada com uma deformação plástica limite de $\bar{\varepsilon}^{p}=\varepsilon_{c}^{p}$ igual a $0,2 \%$, a partir da qual ela fica quase constante. 


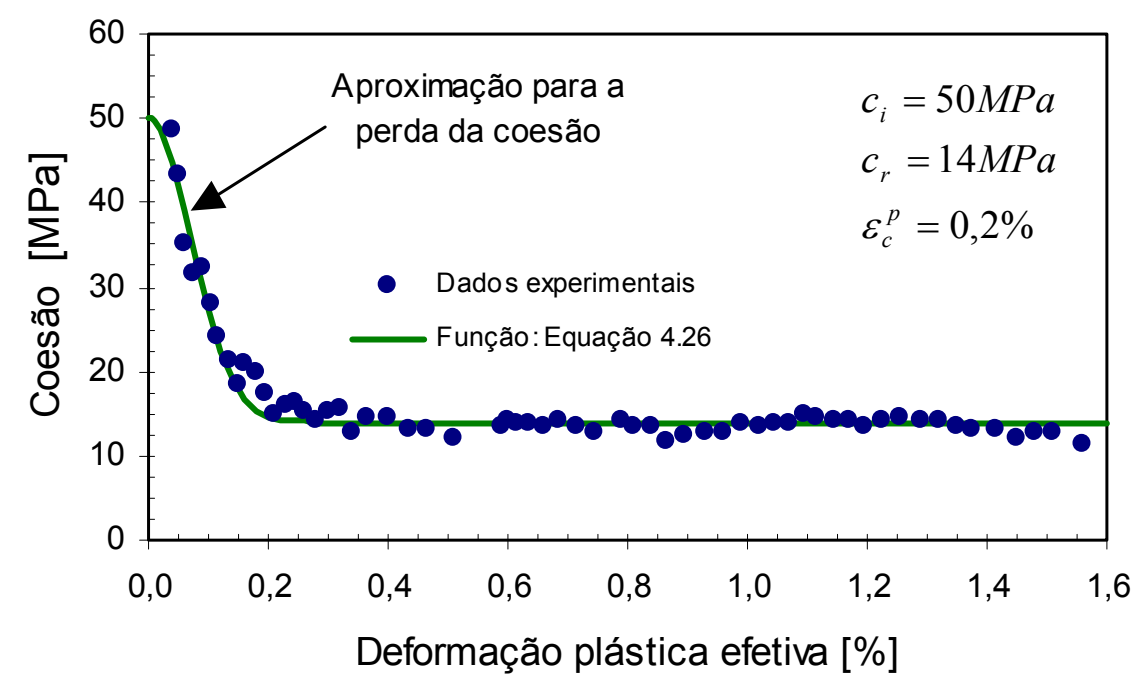

FIGURA 4.15 Amolecimento da coesão no Granito Lac du Bonnet em função da deformação plástica efetiva, $\bar{\varepsilon}^{p}$, ajustada à EQUAÇÃO 4.26.

Na FIGURA 4.16, ilustram-se a mobilização e a degradação do atrito total do Granito Lac du Bonnet em função da deformação plástica efetiva, $\bar{\varepsilon}^{p}$. Os resultados experimentais são razoavelmente representados pela EQUAÇÃO 4.36 para a mobilização, e pela EQUAÇÃO 4.37 para a degradação do atrito total. A máxima mobilização do atrito total está associada a uma deformação plástica limite de $\bar{\varepsilon}^{p}=\varepsilon_{f}^{p}$ igual a $0,32 \%$, a partir da qual se inicia a degradação do atrito até chegar ao atrito residual.

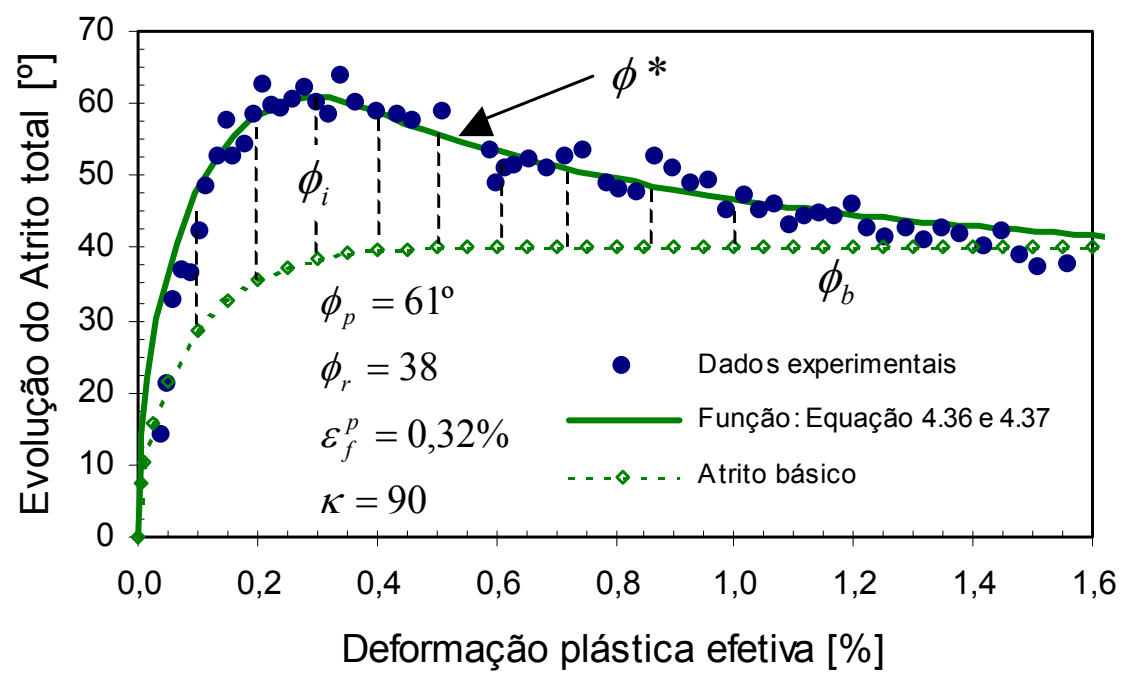

FIGURA 4.16 Comportamento de mobilização e de degradação do atrito total $\left(\phi_{b}+\phi_{i}\right)$ para o Granito Lac du Bonnet em função da deformação plástica efetiva, $\bar{\varepsilon}^{p}$, ajustado às EQUAÇÕES 4.36 e 4.37 . 
Se o atrito total é mobilizado em função da deformação plástica (dano, aparição de micro-fissuras), acredita-se que a parcela devida ao intertravamento e à rugosidade, $\phi_{i}$, começa a ser mobilizada conforme o aparecimento das micro-fissuras (dano) no corpo de prova, atingindo a seu máximo valor quando a resistência global de pico é atingida, ponto a partir do qual o $\phi_{i}$ começa a se degradar com o acúmulo do dano, enquanto que a parcela do atrito básico, $\phi_{b}$, é mobilizada conforme mostrado na FIGURA 4.16. A parcela correspondente ao intertravamento e à rugosidade estaria representada pela região de $\phi_{i}$ da FIGURA 4.16 e fisicamente estaria associada ao desenvolvimento de micro-fissuras, ao mesmo tempo que a degradação do $\phi_{i}$ produz acréscimo de volume.

Os parâmetros de entrada ou as propriedades do Granito Lac du Bonnet a serem usadas na simulação numérica com o modelo de amolecimento da coesão e de endurecimento do atrito por deformação plástica são apresentados na TABELA 4.1.

TABELA 4.1 - Propriedades do Granito Lac du Bonnet usadas no modelo.

\begin{tabular}{ll}
\hline Parâmetro & Valor \\
\hline Coesão inicial, $c_{i}$ & $50 \mathrm{MPa}$ \\
Coesão residual, $c_{r}$ & $14 \mathrm{MPa}$ \\
Resistência à tração, $\sigma_{t}$ & $10 \mathrm{MPa}$ \\
Ângulo de atrito inicial, $\phi_{o}$ & $0^{\circ}$ \\
Ângulo de atrito pico, $\phi$ & $61^{\circ}$ \\
Ângulo de atrito residual, $\phi_{r}$ & $38^{\circ}$ \\
Módulo de elasticidade, $E$ & $60 \mathrm{Gpa}$ \\
Coeficiente de Poisson, $v$ & 0,25 \\
\hline
\end{tabular}

Com a simulação numérica do Granito Lac du Bonnet, foi feita a comparação das curvas tensão axial versus deformação axial, tensão axial versus deformação lateral e deformação volumétrica versus deformação axial obtidas a partir da simulação numérica com a curva experimental. Esta comparação de resultados é apresentada na FIGURA 4.17, que apresenta boa aderência de resultados numéricos aos dados experimentais. Assim, considera-se que o modelo de amolecimento da coesão e de endurecimento do atrito por deformação plástica representou razoavelmente a maior parte das características do comportamento mecânico do granito Lac du Bonnet. 

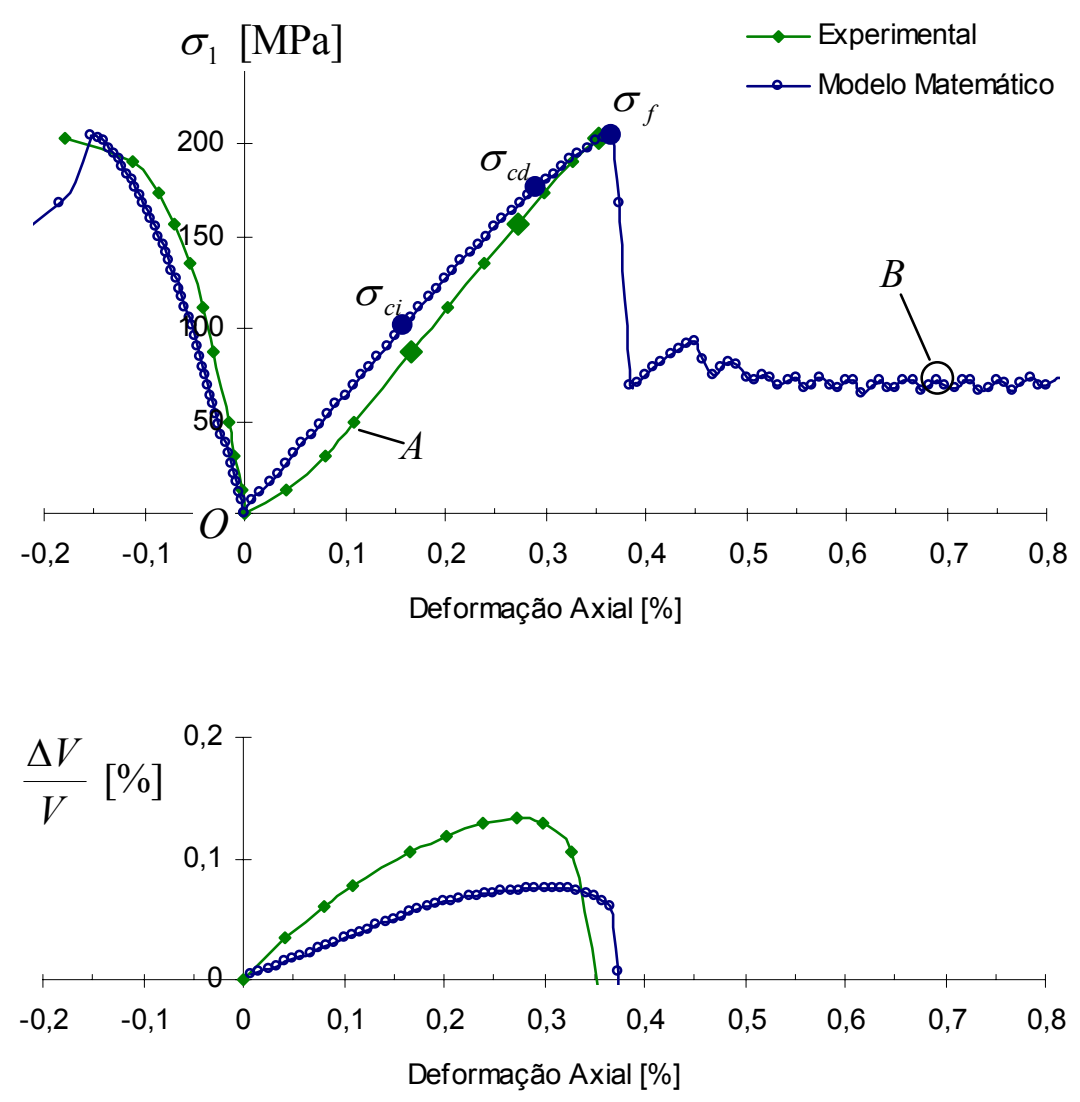

FIGURA 4.17 Comparação de resultados obtidos entre os resultados experimentais e os obtidos pelo modelo de amolecimento da coesão e de endurecimento do atrito por deformação plástica para o Granito Lac du Bonnet.

Na FIGURA 4.17, percebe-se na curva numérica que o regime elástico começa desde a tensão nula até a tensão de início de micro-fissuras ou início do dano $\left(\sigma_{c i}\right)$, enquanto que a curva experimental tem um trecho inicial $(0 A)$ correspondente ao fechamento das micro-fissuras pré-existentes. No trecho $0 \mathrm{~A}$, basicamente, tem-se ganho de rigidez em função do fechamento das micro-fissuras pré-existentes. Em relação à não representatividade do trecho $0 \mathrm{~A}$ pelo modelo adotado, isto se deve basicamente ao fato de que o modelo é contínuo, não admitindo que se considere o efeito de micro-fraturas préexistentes. No entanto, o trecho OA pode ser representado por outros modelos que levem em consideração uma porcentagem de porosidade inicial que represente as micro-fissuras pré-existentes. Apesar desta inconveniência, o modelo de amolecimento da coesão e de endurecimento do atrito por deformação plástica simulou os mecanismos de ruptura envolvidos durante o processo de ruptura.

As tensões associadas ao início de micro-fissuras ou início do dano $\left(\sigma_{c i}\right)$ e a tensão associada ao dano por micro-fraturas $\left(\sigma_{c d}\right)$ obtidas pela simulação numérica foram 
levemente sobre-estimadas em relação aos dados experimentais, como se mostra na FIGURA 4.17. A tensão associada à resistência de pico é considerada como razoavelmente estimada pela simulação numérica.

Na FIGURA 4.18, mostram-se a distribuição da coesão e o ângulo de atrito obtidos a partir da simulação numérica, usando o modelo de amolecimento da coesão e de endurecimento do atrito por deformação plástica para um corpo de prova quando submetido a carregamento de compressão simples. A plotagem da coesão e do atrito corresponde ao ponto B da curva tensão axial-deformação axial da FIGURA 4.17.

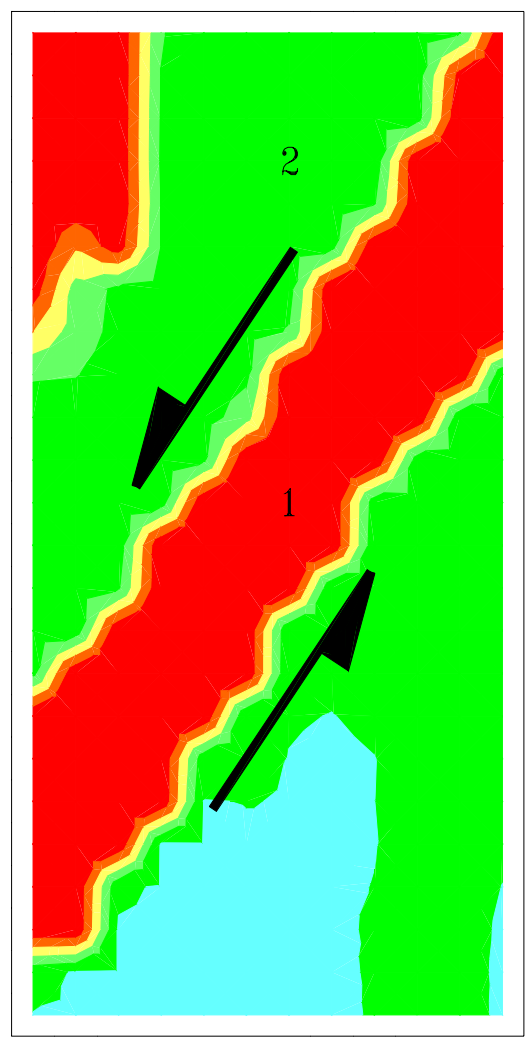

a) Resistência Coesiva

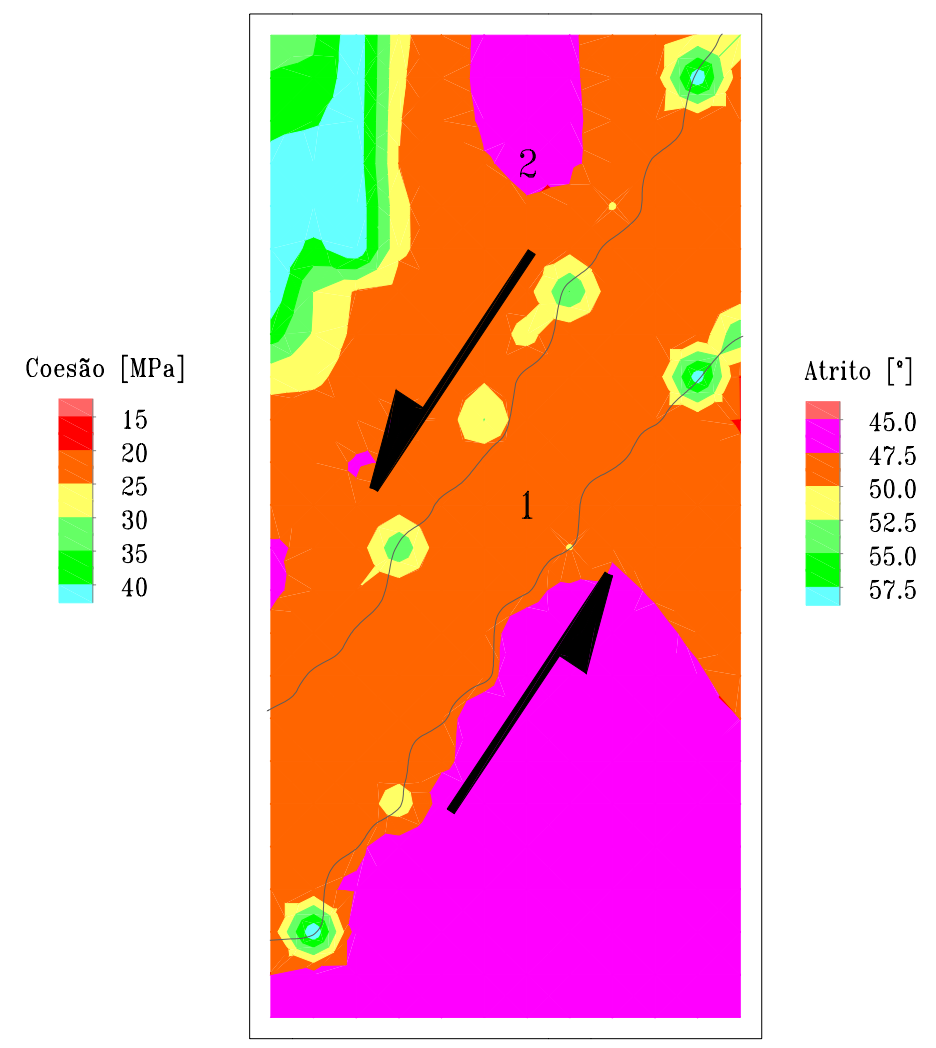

b) Ângulo de atrito

FIGURA 4.18 Simulação numérica do comportamento do Granito Lac du Bonnet, considerando a ruptura progressiva através do modelo de amolecimento da coesão e de endurecimento do atrito por deformação plástica.

A partir da FIGURA 4.18, pode-se dizer que o modelo de amolecimento da coesão e de endurecimento do atrito por deformação plástica representou razoavelmente os mecanismos de ruptura (processo de ruptura) que acontecem num corpo de prova de rocha intacta durante as solicitações. Conforme o modelo, nos primeiros estágios de carregamento, tem-se uma resposta elástica, e a resistência global é basicamente governada pela componente de coesão (coesão inicial). Com o acréscimo do 
carregamento, aparecem as deformações plásticas, as quais estão associadas ao dano do corpo de prova por micro-fissuras, e, por esta razão, a coesão sofre uma diminuição, atingindo o seu valor residual, enquanto que o atrito total é mobilizado até atingir o atrito total de pico. Logo depois, inicia-se a degradação com o acréscimo das deformações plásticas. Na simulação numérica do corpo de prova, foram monitorados dois pontos: o ponto 1 e o ponto 2, os quais estão localizados conforme se mostra na FIGURA 4.18.

A evolução da coesão e do atrito total em função das deformações plásticas (dano) para os pontos 1 e 2 é mostrada na FIGURA 4.19. Nestas figuras, as linhas tracejadas ou não contínuas simplesmente representam os caminhos que devem percorrer tanto a coesão, como o atrito total.
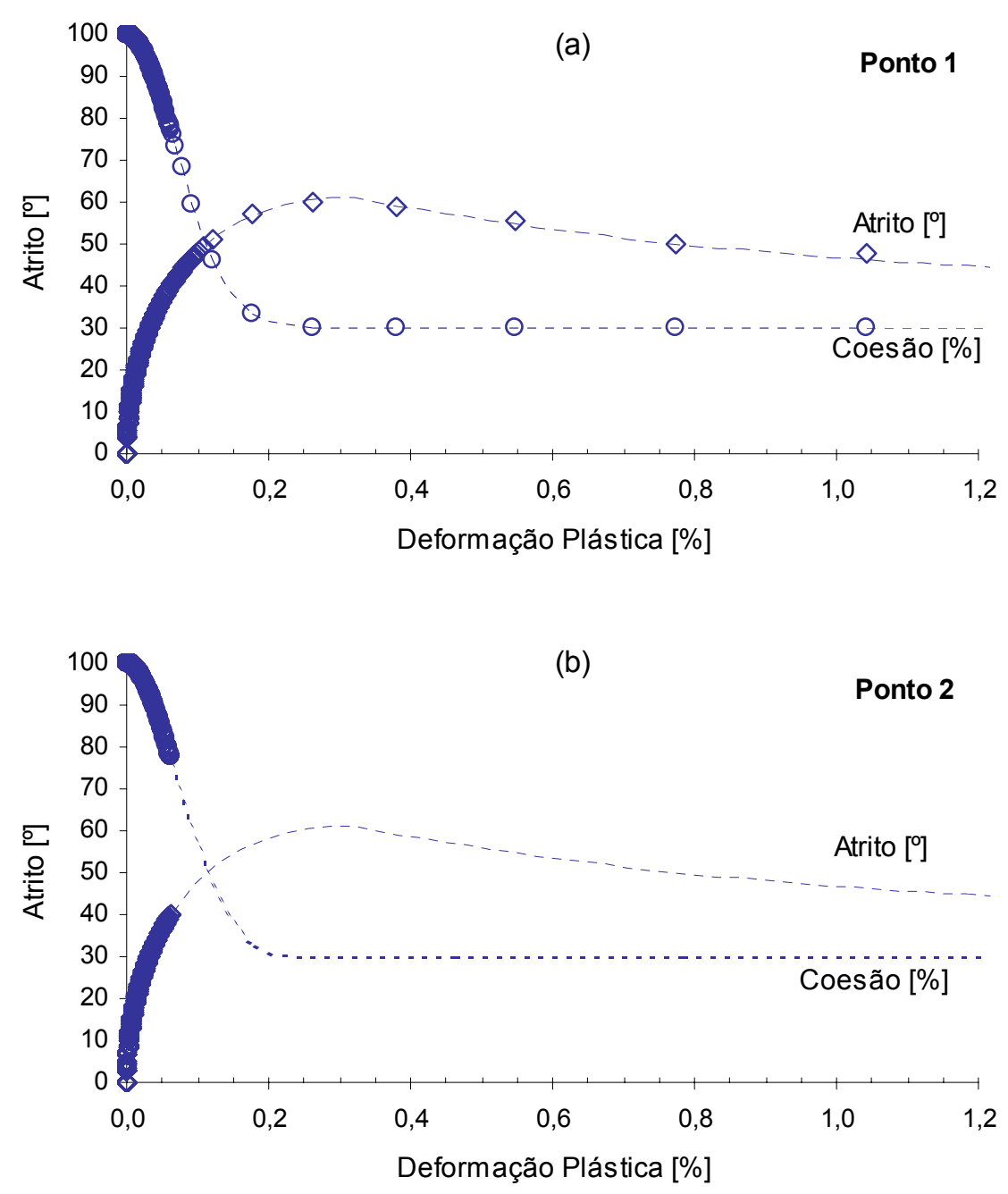

FIGURA 4.19 Evolução da coesão e do atrito total para os pontos de monitoramento 1 (a) e 2 (b), conforme o modelo de amolecimento da coesão e de endurecimento do atrito por deformação plástica. 
Na FIGURA 4.19, o gráfico da evolução da coesão e do atrito versus a deformação plástica para o ponto 1 mostra que a coesão teve a sua máxima perda, chegando ao seu valor residual, enquanto que $\mathrm{o}$ atrito total se mobiliza até atingir o atrito de pico e se degrada com o acréscimo da deformação plástica (dano). O ponto 1 se encontra localizado na provável superfície de ruptura do corpo de prova, onde, ao longo desta superfície, o comportamento é similar ao comportamento do ponto 1. Na região por onde se estende a provável superfície de ruptura, ocorrem as máximas deformações plásticas relacionadas à maior danificação do corpo de prova por micro-fissuras. Nesta área, a resistência estaria governada basicamente pelo atrito. Por outro lado, o gráfico da evolução da coesão e do atrito versus a deformação plástica para o ponto 2 mostra que a coesão sofre apenas um decréscimo em aproximadamente $23 \%$ do valor inicial, enquanto que o atrito somente foi mobilizado, atingindo a magnitude de $50^{\circ}$.

\subsection{Discussão}

A FIGURA 4.20 mostra a coesão normalizada (coesão dividida pela coesão de pico) versus o ângulo de atrito total (dados da FIGURA 3.5, Capítulo 3). Conforme este gráfico, observa-se claramente que, para a rocha intacta com um número mínimo de micro-fissuras pré-existentes, a resistência global está basicamente governada pela coesão. À medida que no corpo de prova aparecem micro-fissuras devido ao dano induzido pelas cargas aplicadas, a resistência global do corpo de prova passa a ser governada por uma parcela da coesão e outra de atrito. Este gráfico apresenta uma característica na qual a coesão diminui gradativamente em função do micro-fraturamento, enquanto que o atrito sofre um acréscimo com o micro-fraturamento. Desta forma, quanto mais micro-fraturado se encontra o corpo de prova, mais a resistência será governada pelo atrito e por uma parcela muito baixa de coesão. Por outro lado, quando a coesão chega ao seu valor residual e o atrito ao seu valor máximo, inicia-se a degradação do atrito, chegando a um atrito residual. Esta degradação do atrito se dá com uma coesão quase constante e igual à coesão residual. 


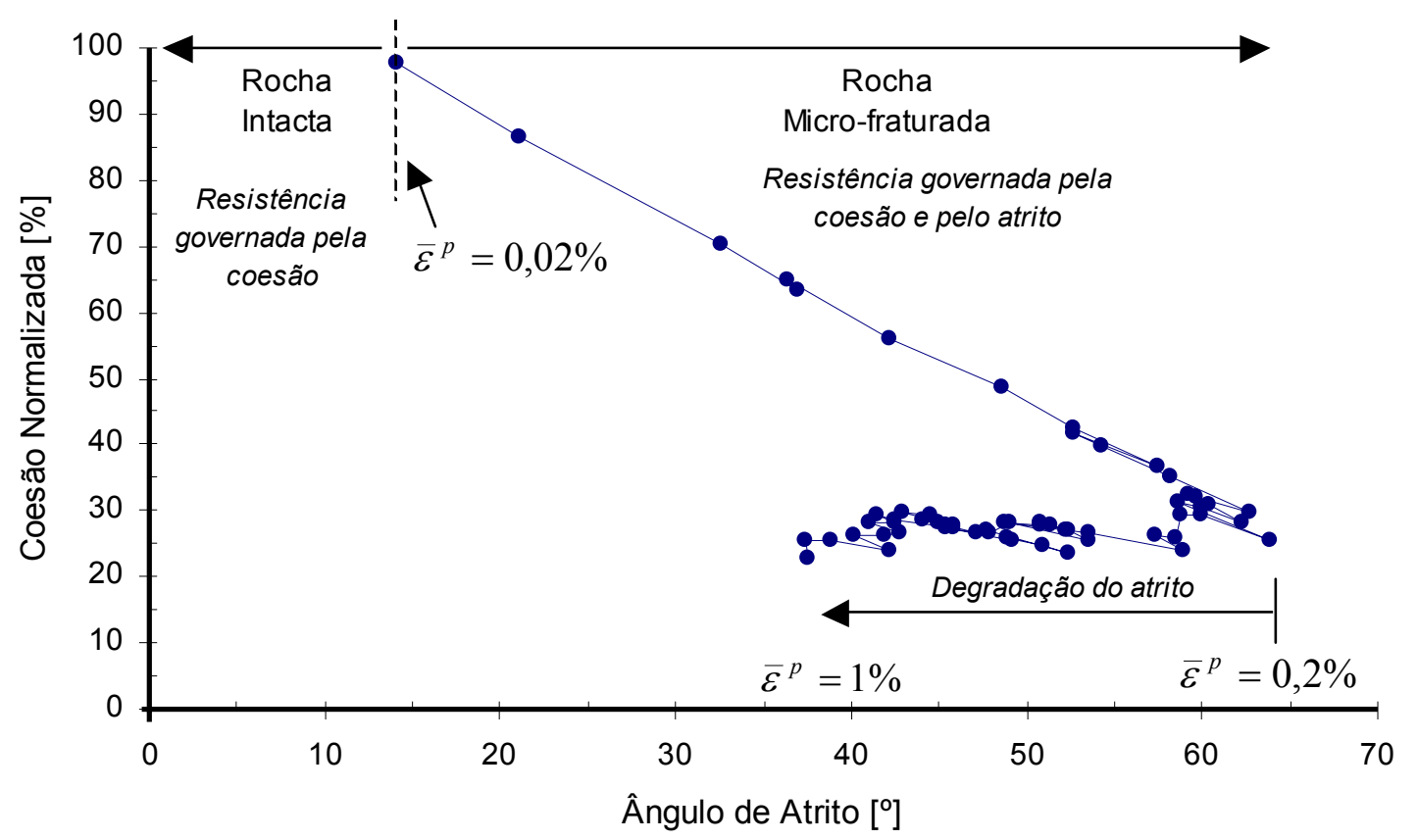

FIGURA 4.20 Evolução da coesão normalizada versus ângulo de atrito total durante o processo de ruptura (ensaios cíclicos) para o Granito Lac du Bonnet.

A partir da analogia da FIGURA 4.20, pode-se ampliar este enfoque para o maciço rochoso. Na FIGURA 4.21, mostram-se, hipoteticamente, dois corpos de prova sem escala alguma, um intacto e outro representativo de um maciço rochoso. Sabe-se que a resistência da rocha intacta é governada pela coesão. Entretanto, para um maciço rochoso conforme apresentado nas FIGURAS 4.20 e 4.21, a resistência global passa a estar governada por uma parcela de coesão e outra de atrito. Acredita-se que no maciço rochoso, dependendo do grau de fraturamento, vão existir as pontes rochosas entre as descontinuidades, pontes estas que tendem a diminuir com o grau de fraturamento. Assim, em maciços rochosos a resistência coesiva devida às pontes rochosas, é muito baixa quando comparado à rocha intacta.

Do discutido anteriormente e em analogia com as FIGURAS 4.20 e 4.21, para um maciço rochoso, quanto maior o fraturamento, a resistência global passa a ser governada por uma porcentagem cada vez maior de atrito, enquanto que a resistência coesiva diminui gradativamente. 
Rocha Intacta (RI)

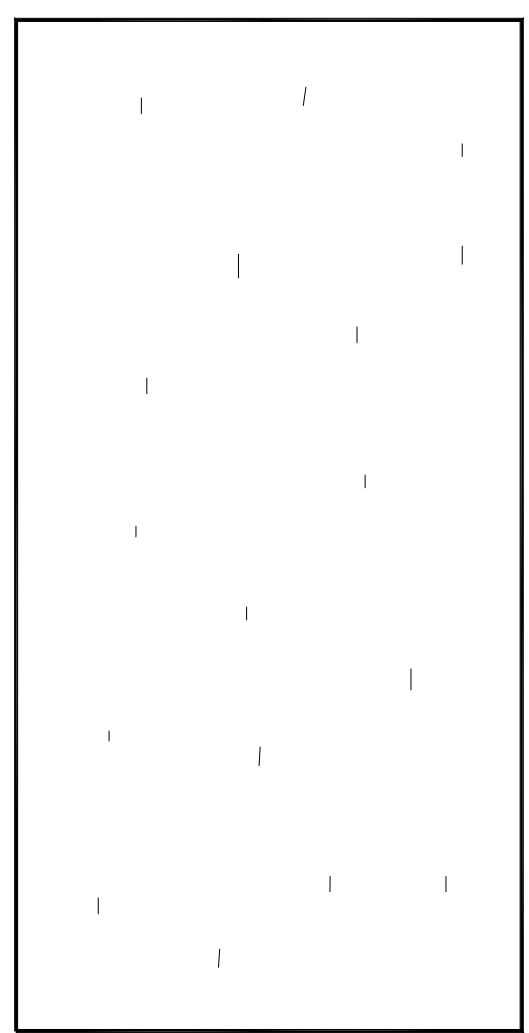

Maciço Rochoso (MR)

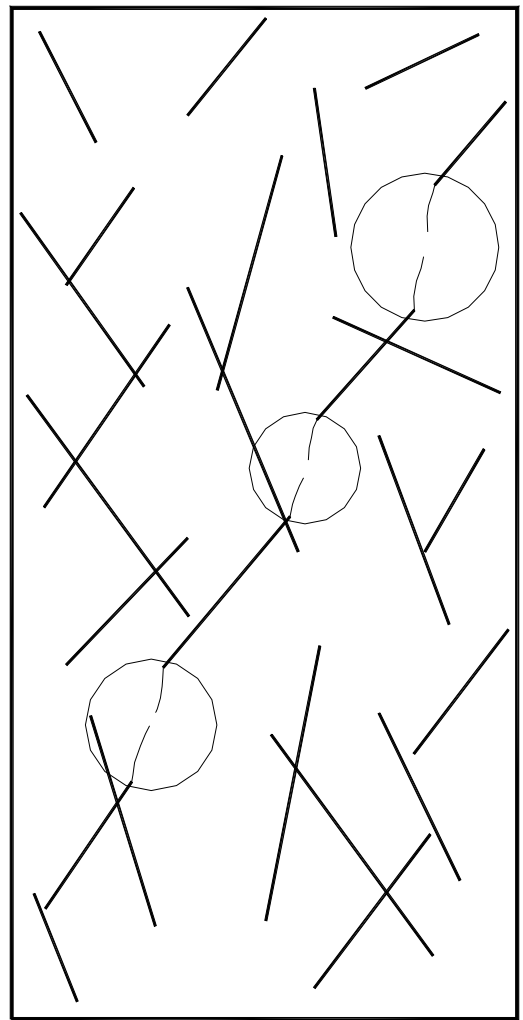

Acréscimo do grau de fraturamento

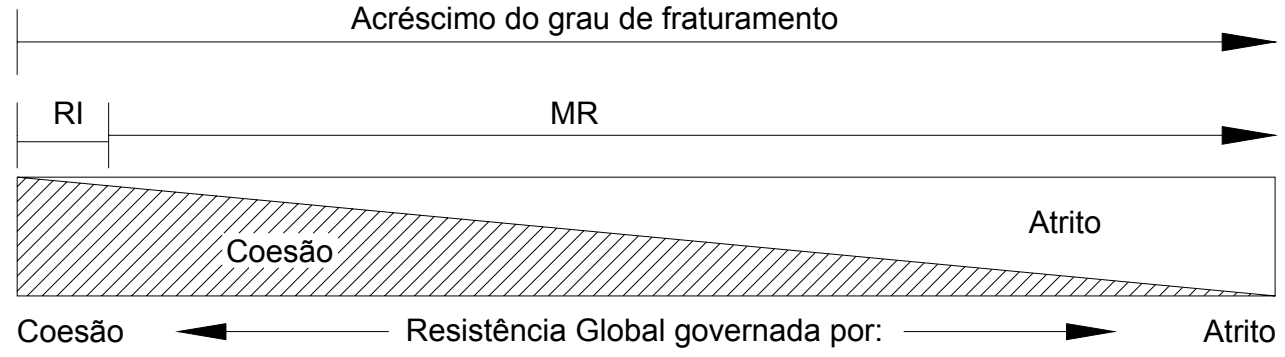

FIGURA 4.21 Comparação entre a rocha intacta e o maciço rochoso.

Baseado nas discussões das FIGURAS 4.20 e 4.21, pode-se representar, de forma quase empírica, a rocha intacta e o maciço rochoso de forma conjunta conforme mostrado na FIGURA 4.22. Neste gráfico, a linha não contínua representaria esquematicamente a trajetória da rocha intacta para um maciço rochoso, considerando, em forma implícita, o grau de fraturamento. Assim, a coesão diminui com o acréscimo do fraturamento (maciço rochoso) e a resistência passa gradativamente a ser governada pelo atrito. 


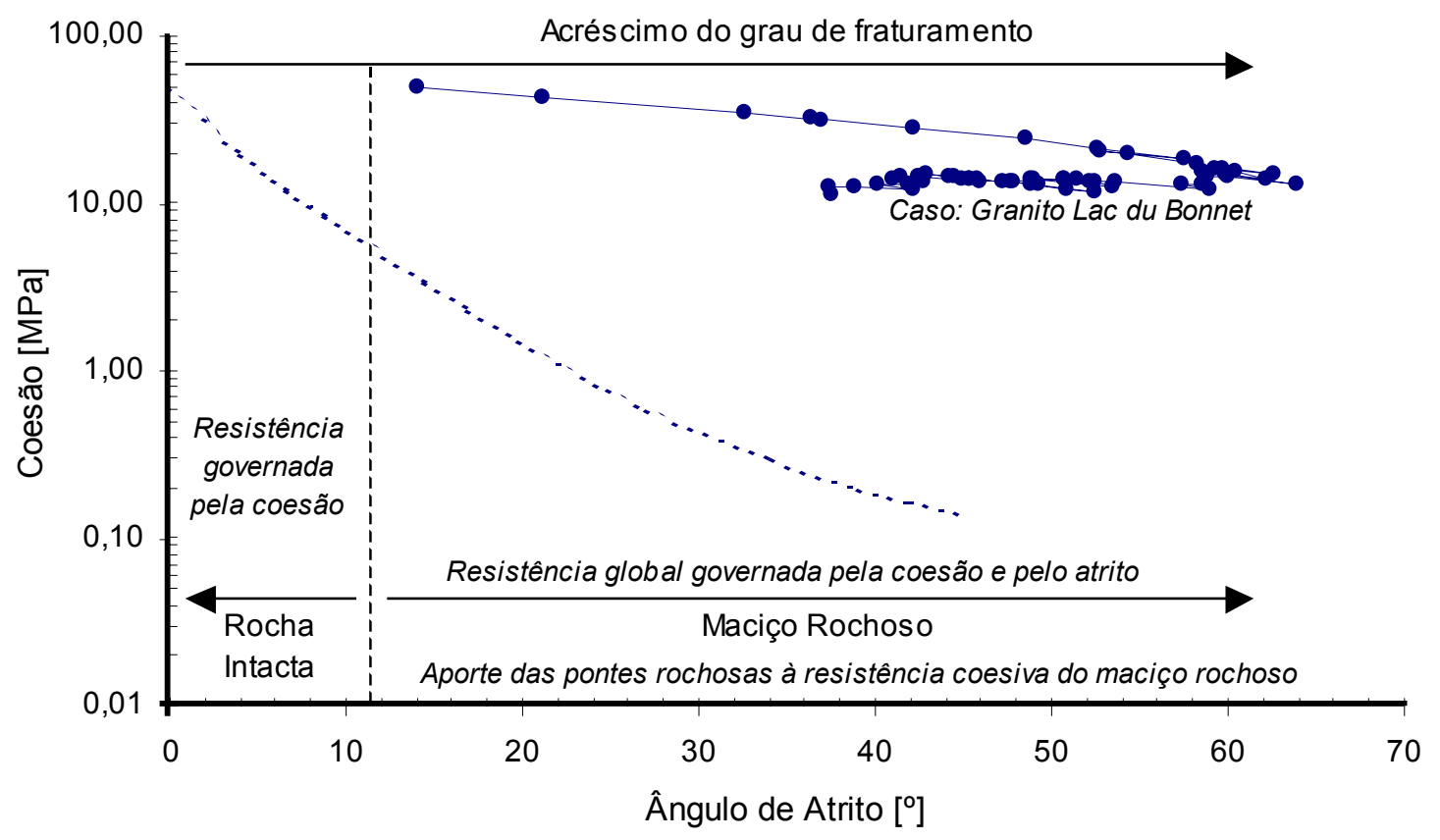

FIGURA 4.22 Coesão versus ângulo de atrito total: evolução da rocha intacta ao maciço rochoso.

Então, para o caso de um maciço rochoso quando comparado com a rocha intacta, a resistência coesiva é muito menor, isto devido ao grande número de descontinuidades contidas no maciço rochoso. Se compararmos as micro-fissuras (corpo de prova) com as descontinuidades (maciço rochoso) e se considerarmos que o atrito é mobilizado com o acréscimo de micro-fissuras no corpo de prova, pode-se dizer então que, para o caso do maciço rochoso, devido às descontinuidades, o atrito já se encontraria mobilizado em uma certa porcentagem. No enfoque do modelo de amolecimento da coesão e de endurecimento do atrito por deformação plástica, a EQUAÇÃO 4.36 que simula o endurecimento do atrito em função do dano considera como um parâmetro o atrito mobilizado inicial $\left(\phi_{o}\right)$. É então possível indicar o atrito mobilizado inicial para o caso de simulações de maciços rochosos.

Para um maciço rochoso com certas características de fraturamento, no enfoque de análise com o modelo de amolecimento da coesão e de endurecimento do atrito por deformação plástica, os parâmetros de entrada correspondentes à coesão e ao atrito seriam os correspondentes a um ponto localizado aproximadamente dentro da linha não contínua da FIGURA 4.22. 


\section{Capítulo 5}

\section{Modelagem Numérica de Taludes Altos}

\subsection{Introdução}

A estabilidade, para propósitos práticos de engenharia, é usualmente avaliada considerando-se a relação entre resistência e a tensão atuante. Assim, a instabilidade apresenta-se quando as solicitações tendam a exceder à resistência.

Vários estudos da prática de engenharia apresentam estimativas de variações das tensões (induzidas) devido ao processo de escavação. No entanto, é difícil interpretar as variações das tensões medidas. Para estudar estas variações, KAISER et al. (2001) fizeram um estudo de variações das tensões induzidas decorrentes do processo de escavação da Mina Subterrânea Winston Lake (Canadá). Fizeram uso de modelos tridimensionais para explicar as observações de campo, comparando as tensões medidas no campo com aquelas obtidas pela modelagem. Para a modelagem, fizeram uso do programa MAP3D, em regime elástico linear, isotrópico e homogêneo. As previsões encontradas foram consideradas razoavelmente confiáveis para o maciço em estado compressivo (diante da frente de avanço). Para pontos localizados na borda da escavação, atrás da face, quando a delaminação e a relaxação ocorrem, o modelo elástico tende a sobre-estimar a relaxação (alívio) de tensões, mas as tendências observadas podem ser obtidas de tais análises.

EBERHARDT (2001) fez um estudo detalhado de tensões baseadas em análises tridimensionais pelo método de elementos finitos, no qual pesquisou a evolução e o desenvolvimento progressivo das tensões induzidas e a trajetória das mesmas durante o avanço da frente de escavação de um túnel hipotético. Aquele autor analisou as variações da magnitude e a rotação das tensões principais usando um modelo elástico linear e um 
elasto-plástico. Segundo aquele autor, as tensões obtidas pelo modelo elasto-plástico são significativamente menores ao longo do teto do túnel, por onde se estende a plastificação a uma distância de aproximadamente 0,2 vezes o diâmetro do túnel a partir da sua borda. De 0,2 a 0,5 vezes o diâmetro a partir da borda do túnel, as tensões plásticas são maiores que as tensões elásticas, o que se deve, segundo o autor, ao fenômeno de acúmulo de tensões fora dos elementos plastificados ou nos elementos que ainda têm capacidade de suporte.

Para casos de taludes altos, segundo SJÖBERG (1999), existem poucos estudos sobre o estado de tensões em escavações a céu aberto, os quais foram realizados através de análises fotoelásticas e de análises numéricas como as de STACEY $(1970,1973)$.

Com a finalidade de entender os mecanismos ou fenômenos que acontecem durante o processo de escavação de taludes altos de mineração a céu aberto, no presente trabalho foram feitas duas análises: (a) Análise de tensões elásticas, e (b) Análise com o modelo de amolecimento da coesão e de endurecimento do atrito. $\mathrm{Na}$ análise de tensões elásticas basicamente vai-se discutir a trajetória de tensões induzidas, estas decorrentes do avanço de escavação. Na análise com o modelo de amolecimento da coesão e de endurecimento do atrito vai ser discutida a danificação do maciço rochoso como conseqüência das tensões induzidas decorrentes do avanço da escavação.

\subsection{Considerações e Descrição do Modelo}

Para estudar os mecanismos de ruptura em taludes altos foram estabelecidas algumas considerações a serem feitas no modelo. Nos modelos, foi adotado o estado plano de deformações, fazendo-se uso do modelo elástico linear e do modelo elastoplástico de amolecimento da coesão e de endurecimento do atrito para taludes de $300 \mathrm{e}$ 600 metros de altura e ângulo de inclinação de $40^{\circ}$. Todas as análises foram feitas com o programa FLAC ${ }^{2 D}$ (ITASCA, 1995).

O primeiro passo para a simulação numérica foi definir a construção do modelo, basicamente no que se refere aos aspectos geométricos a serem considerados nas análises. Para a construção do modelo, considerou-se a seção inteira da cava, o que possibilitou simular dois ângulos de taludes diferentes. Por exemplo, numa mesma análise, adotou-se um talude de $40^{\circ}$ e outro de $30^{\circ}$, sendo o talude crítico aquele de maior ângulo, sobre o qual foram realizadas as análises. Seguiram-se as recomendações de SJÖBERG (1999) de análises numéricas para taludes com o programa $F L A C^{2 D}$, segundo as quais o modelo deve ter três vezes a largura $(\mathrm{L})$ da cava e altura com três vezes a profundidade 
final da cava, isto para casos de modelos plásticos. Para modelos elásticos, recomenda-se que a largura seja ainda maior (4L). Um modelo típico adotado nas análises é apresentado na FIGURA 5.1.

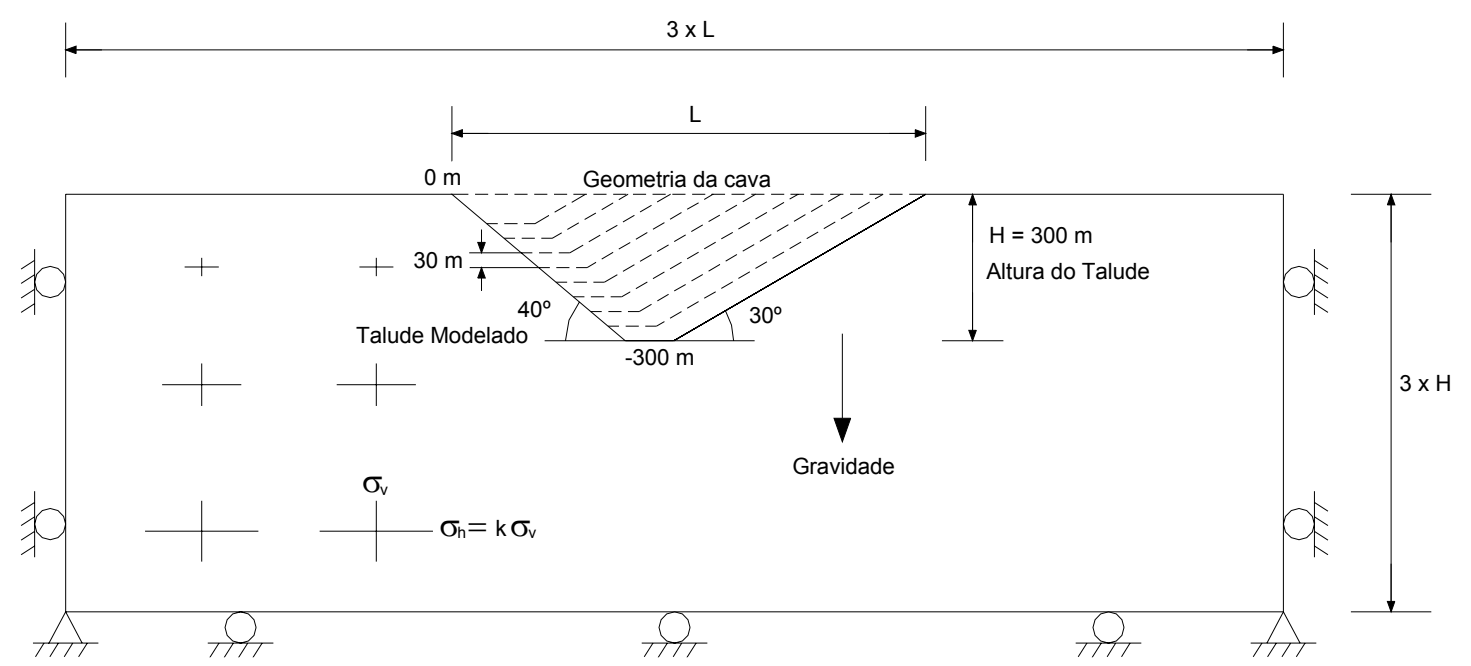

FIGURA 5.1 Condições de contorno e estado de tensões iniciais para modelos de taludes empregados nas análises numéricas com o programa $\mathrm{FLAC}^{2 \mathrm{D}}$.

As condições de contorno para o problema em estudo são apresentadas na FIGURA 5.1. Nos lados direito e esquerdo, foram permitidos deslocamentos na direção vertical, restringindo-se os deslocamentos na direção horizontal; na base, permitiu-se o deslocamento na direção horizontal, restringindo-se os deslocamentos na direção vertical; na parte superior, a superfície foi mantida livre.

O estado de tensões iniciais foi gerado no modelo. Para uma profundidade $z$, a tensão vertical, $\sigma_{v}$, é dada pelo produto desta profundidade pelo peso específico do maciço sobrejacente, $\gamma$, ou seja:

$$
\sigma_{v}=\gamma \cdot z
$$

Fazendo uso da EQUAÇÃO 5.1 na geração do estado de tensões iniciais, assumese que a tensão vertical tem um acréscimo linear com a profundidade.

Para a estimativa da tensão horizontal, $\sigma_{h}$, considerou-se:

$$
\sigma_{h}=k \sigma_{v}
$$


onde $k$ é o coeficiente de empuxo. Nas análises adotaram-se valores de $k$ iguais a 1,$1 ; 1,3 ; 1,5$ e 1,7 .

Os parâmetros de entrada para a simulação numérica são os correspondentes à rocha Diorito da Mina Toquepala, Peru (CARVALHO et al., 2002). Esta Mina é localizada na Cordilheira Ocidental dos Andes no sul do Perú, numa altitude entre 3000 e 3700 m., sendo a jazida do tipo cobre pórfiro.

A partir dos parâmetros do critério de Hoek-Brown $\left(m_{i}, \sigma_{c}\right.$ e $\left.G S I\right)$ correspondentes ao maciço rochoso, foi avaliada a resistência da rocha Diorito em termos do critério de Mohr-Coulomb $(c, \phi)$, sendo tais parâmetros os correspondentes aos dados de entrada na simulação numérica. A resistência do maciço rochoso foi estimada usando o critério de ruptura de Hoek-Brown (2002). Os parâmetros de coesão e de atrito foram estimados através da regressão linear sobre uma faixa de tensões de confinamento entre 0 e $6 \mathrm{MPa}$ e com a resistência à compressão uniaxial igual tanto para o critério de HoekBrown, como para o Mohr-Coulomb. Também foi adotado o parâmetro de perturbação como $D=0$. O módulo de elasticidade para o maciço rochoso, $E_{m}$, foi estimado a partir de resultados da classificação geomecânica RMR, conforme as recomendações de SERAFIM e PEREIRA (1983). Na TABELA 5.1, são apresentados os parâmetros de entrada para a simulação numérica.

TABELA 5.1 Parâmetros de entrada a serem usados na simulação numérica bidimensional tensão-deformação.

\begin{tabular}{ll}
\hline Parámetro & Valor \\
\hline Densidade, $d$ & $2600 \mathrm{~kg} / \mathrm{m}^{3}$ \\
$m_{i}$ & 25 \\
$\sigma_{c}$ & $50 \mathrm{MPa}$ \\
$E_{i}$ & $55 \mathrm{GPa}$ \\
$R M R$ & 49 \\
$G S I$ & 45 \\
$c^{* *}$ & $0,407 \mathrm{MPa}$ \\
$\phi^{* *}$ & $46^{\circ}$ \\
$v$ & 0,25 \\
$E_{m}{ }^{* *}$ & $10 \mathrm{GPa}$ \\
\hline
\end{tabular}

$\left.{ }^{(* *}\right)$ Parâmetros estimados. 
Na FIGURA 5.2, apresentam-se às envoltórias de resistência de Hoek-Brown e de Mohr-Coulomb estimadas para o maciço rochoso (rocha Diorito). Também, são apresentados os resultados obtidos por CARVALHO et al. (2002), que estimaram a resistência do Diorito da Mina Toquepala através da simulação numérica, usando o programa UDEC.

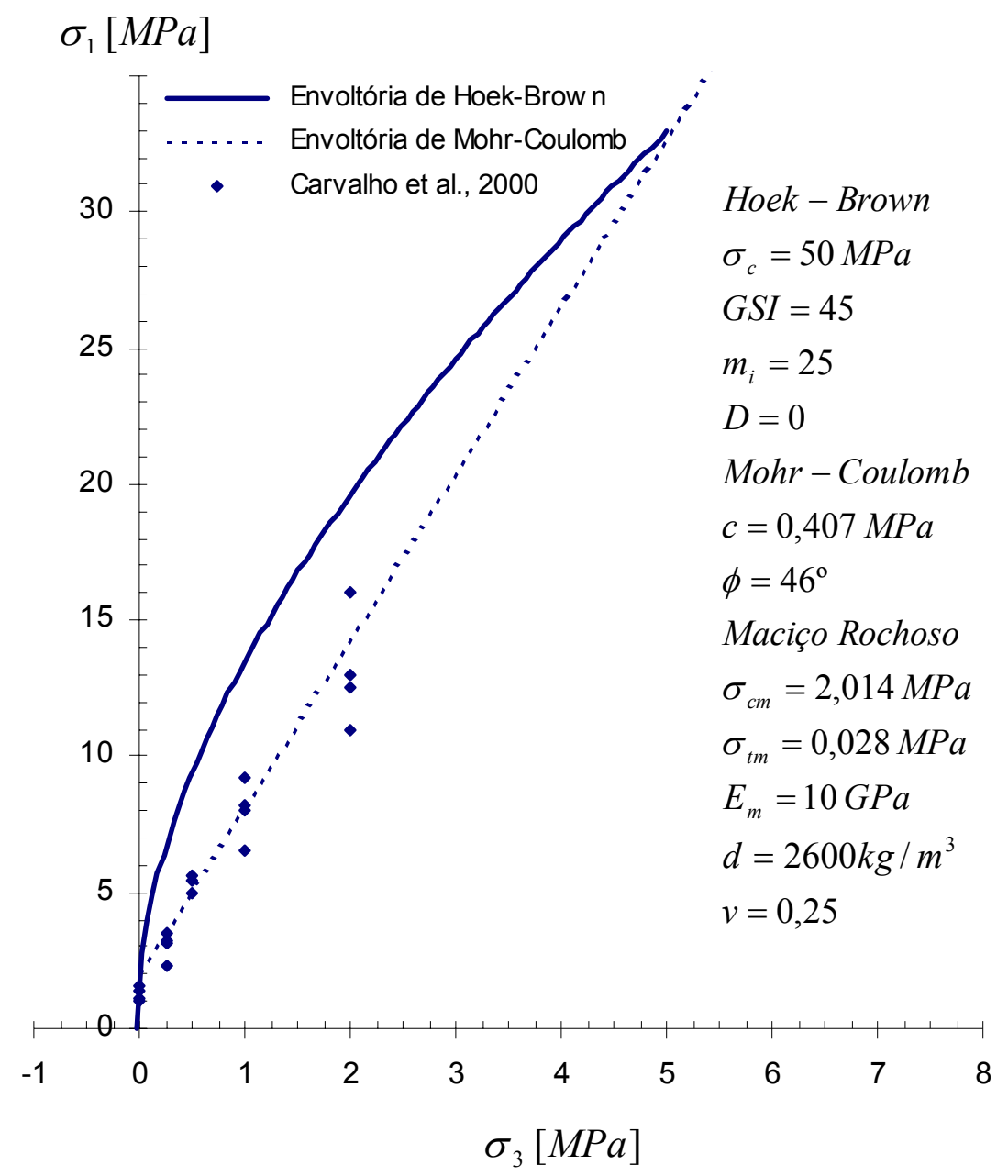

FIGURA 5.2 Envoltória de ruptura de Hoek-Brown e Mohr-Coulomb para o maciço de Diorito, Mina Toquepala, Peru.

Com a finalidade de reproduzir ou simular o processo evolutivo da escavação de um talude de mineração a céu aberto, foi simulado, na modelagem numérica, o avanço da escavação em estágios de 30 metros por vez, reproduzindo, assim, uma escavação em bancadas com altura de 30 metros, conforme apresentado na FIGURA 5.1.

Nas análises, a largura da base da cava foi mantida constante e igual a 100 metros para todas as simulações, não sendo objeto de estudo a influência desta largura. 


\subsection{Análise de Trajetória de Tensões Elásticas}

Entende-se basicamente que, com o processo de escavação tanto em escavações subterrâneas como a céu aberto, o maciço rochoso é perturbado com a remoção do material. Esta perturbação do maciço é decorrente das mudanças da geometria. Assim, por uma certa variação geométrica, seja pela escavação de um túnel ou um talude no maciço, as tensões iniciais ou virgens vão experimentar alívio e redistribuição. Como produto desta redistribuição de tensões, pode-se ter regiões com concentração de tensões e regiões com alívio de tensões.

Conforme as análises preliminares, para o caso da FIGURA 5.1, onde o avanço da escavação ocorre em estágios, o estado de tensões iniciais sofre mudanças tanto de magnitude, como de orientação, e ambas obedecem às mudanças da geometria. Com a finalidade de conhecer a evolução ou trajetória de tensões e as suas influências na estabilidade, foram monitoradas em diferentes pontos do talude as tensões. $\sigma_{1}$ e $\sigma_{3}$, conforme se mostra nas FIGURAS 5.3 e 5.4 .

Os pontos de monitoramento se encontram localizados em regiões próximas ao pé do talude nos respectivos estágios de escavação. Estes pontos estão localizados em profundidades de 60, 120, 180, 240 e 300 metros, respectivamente. Foram monitorados outros cinco pontos ao longo de uma provável superfície de ruptura, em profundidades de $10,90,150,210$ e 240 metros respectivamente.

\subsubsection{Tensões Elásticas ao Longo da Face}

Na FIGURA 5.3, mostram-se a evolução ou as trajetórias das tensões principais . $\left(\sigma_{1}\right.$ e $\left.\sigma_{3}\right)$ em relação ao avanço da escavação, para um talude de $300 \mathrm{~m}$ de altura, $40^{\circ}$ de ângulo de talude e $k=1,1$. Neste gráfico, nota-se que a tensão $\sigma_{1}$ cresce nas regiões do pé do talude para cada estágio de escavação, fenômeno este denominado como acúmulo de tensões. Com o avanço da escavação e na nova configuração geométrica, a região que era pé do talude passa a corresponder a uma zona ou região de alívio de tensões, diminuindo a magnitude do $\sigma_{1}$. Já para $\sigma_{3}$, em todos os pontos, durante a escavação, ocorre perda de confinamento. 


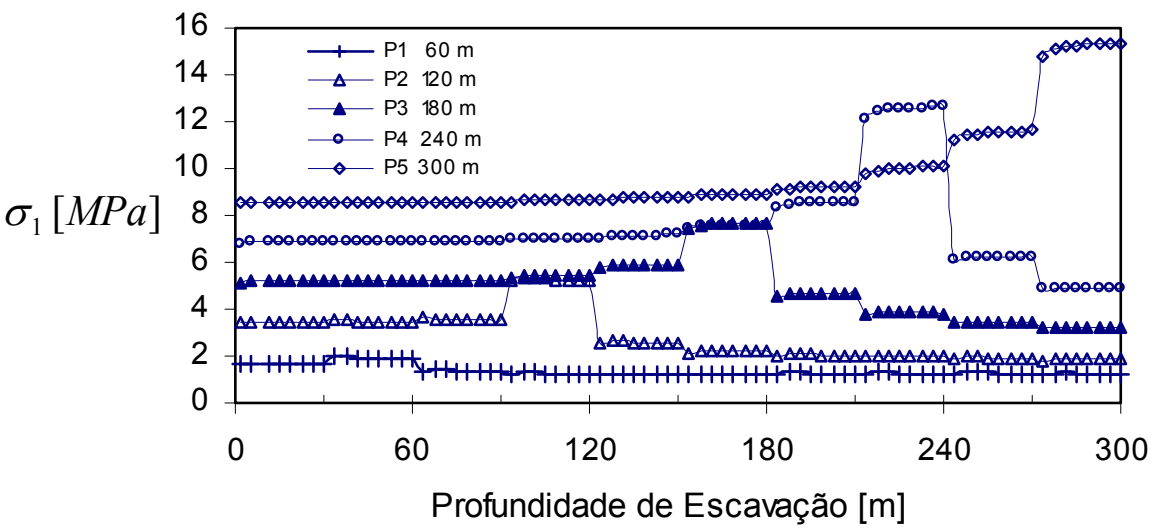

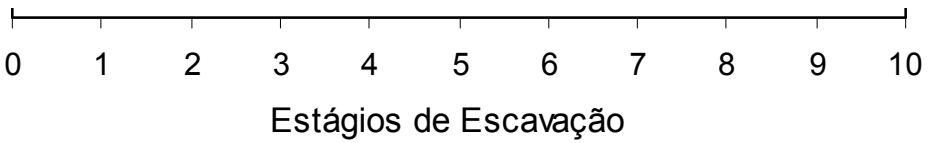

Talude Global

$300 \mathrm{~m}$
Começo da escavação

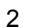

3

Estágio de escavação
5

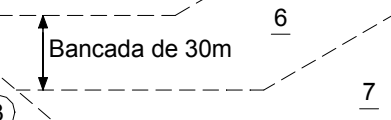

9

10
(2) Pontos de monitoramento

(5) Final da escavação

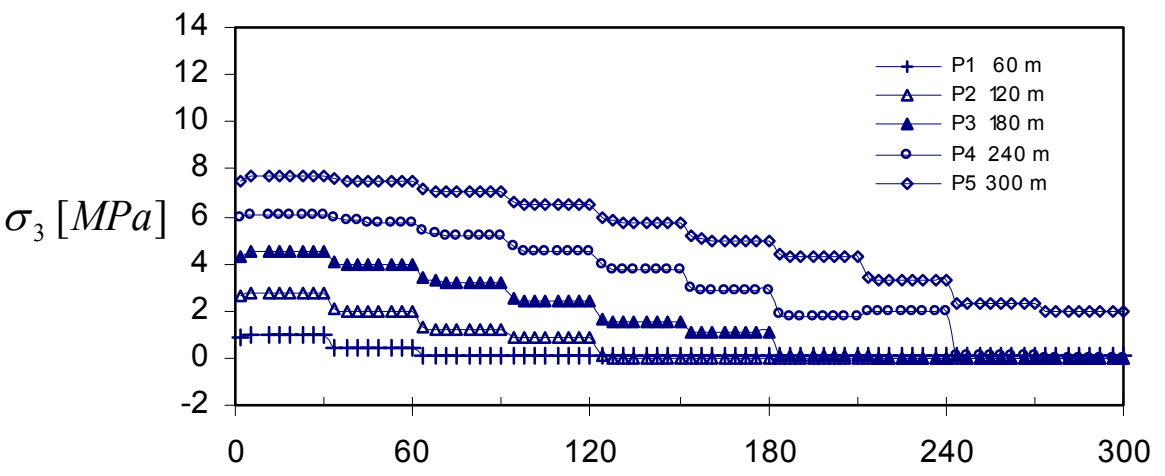

Profundidade de Escavação [m]

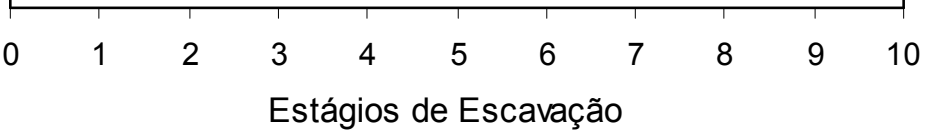

FIGURA 5.3 Evolução das tensões principais em decorrência do avanço da escavação, para pontos localizados próximo do pé do talude, nos diferentes estágios de escavação, num talude final de $300 \mathrm{~m}$ de altura, $40^{\circ}$ de inclinação, e $k=1,1$. 
Conforme a FIGURA 5.4, a orientação da tensão principal maior, $\sigma_{1}$, varia em relação ao avanço da escavação desde a horizontal (devido à adoção do coeficiente de empuxo, $k$, maior que 1 , no caso da FIGURA $5.4, k=1,1)$ até $10^{\circ}$ em relação à horizontal para um estágio de escavação antes de se chegar ao pé do talude. Para todos os casos, a orientação de $\sigma_{1}$, no momento de acúmulo de tensões, corresponde em média a $22^{\circ}$. Com o avanço da escavação, $\sigma_{1}$ tende a se alinhar paralelamente à face do talude, sendo que, para o caso analisado, ela tende a um ângulo de $40^{\circ}$.
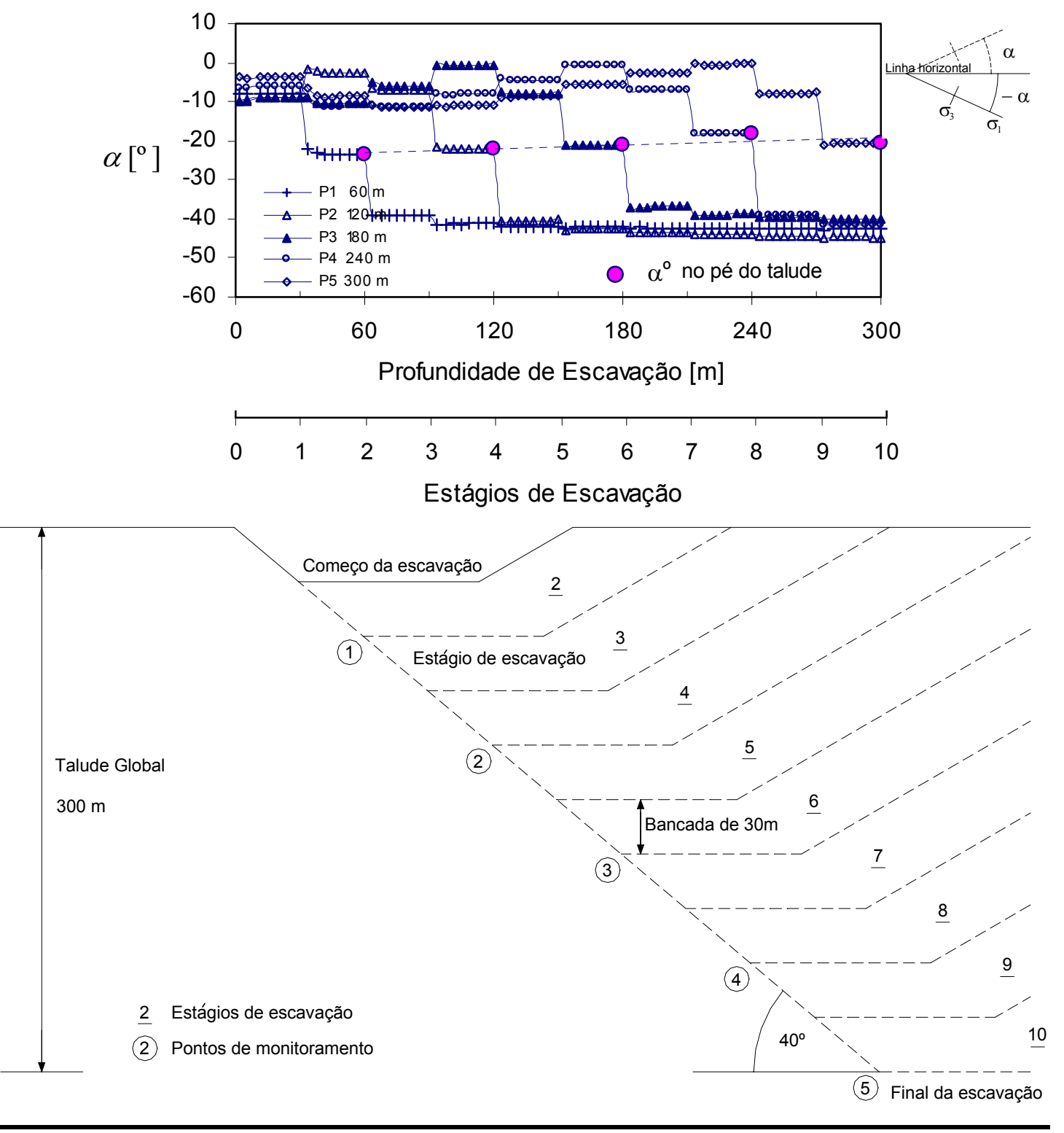

FIGURA 5.4 Rotação das tensões principais em decorrência do avanço da escavação, para pontos localizados próximo do pé do talude, nos diferentes estágios de escavação, num talude final de $300 \mathrm{~m}$ de altura, $40^{\circ}$ de inclinação, e $k=1,1$.

Exemplificando na FIGURA 5.3, seja o ponto 3 localizado a $180 \mathrm{~m}$ de profundidade. A trajetória de tensões percorrida entre os estágios de escavações de 1 a 5 
correspondem à perda do confinamento, com ligeiro acréscimo de $\sigma_{1}$. A orientação de $\sigma_{1}$ varia de $0^{\circ}$ a aproximadamente $10^{\circ}$ em relação à horizontal. No estágio 6 , tem-se o acúmulo de tensões e $\sigma_{1}$ cresce de $5,9 \mathrm{MPa}$ (estágio 5) a 7,6 $\mathrm{MPa}$, ao passo que $\sigma_{3}$ diminui de 1,51 MPa (estágio 5) a 1,08 MPa e a orientação de $\sigma_{1}$ se encontra em média com $22^{\circ}$. Nos estágios 7 até 10 , tem-se perda do $\sigma_{1}$, que diminui para 4,7 MPa no estágio 7 (perda rápida de $\sigma_{1}$ ) e até $3,2 \mathrm{MPa}$ no estágio 10 , passando a corresponder a uma região de alívio de tensões quando a escavação está no estágio 10. Estas mudanças de $\sigma_{1}$ tornam-se mais críticas com o acréscimo da profundidade (pontos 4 e 5).

Por outro lado, enquanto acontece o acúmulo de tensões no ponto 3 (estágio 6), nos pontos 1 e 2 ocorre a diminuição de $\sigma_{1}$ (alívio), sendo que estes últimos dois pontos já sofreram o acúmulo de tensões nos estágios de escavação 2 e 4, respectivamente. Os pontos 4 e 5 continuam numa perda gradativa do confinamento, sendo que $\sigma_{1}$ se mantém constante, sofrendo acréscimos mínimos.

Dos fatos mencionados em relação ao acúmulo de tensões, verifica-se que a trajetória de tensões decorrentes da modificação da geometria, no caso do avanço da escavação, pode gerar alteração do maciço, modificando os seus parâmetros de resistência.

Na FIGURA 5.5, mostram-se as trajetórias de tensões dos cinco pontos localizados ao longo da face do talude, no diagrama $\sigma_{1}-\sigma_{3}$. Com base nestas trajetórias, observa-se que os cinco pontos correspondem à perda de confinamento com o avanço da escavação, sendo que esta mesma situação é também observada, agora com mais clareza, no gráfico de $\sigma_{3}$ versus a profundidade da escavação, conforme ilustrada na FIGURA 5.3.

Conforme a FIGURA 5.5, as tensões elásticas ultrapassam a envoltória da resistência adotada de Mohr-Coulomb e de Hoek-Brown correspondente à rocha Diorito, o que significa que, teoricamente, a rocha naquelas regiões (pontos monitorados) atinge à condição de ruptura. Nota-se que, no ponto 1 (a $60 \mathrm{~m}$ de profundidade), as tensões não ultrapassam a envoltória, apenas alcançando-a. Já para profundidades maiores, as tensões ultrapassam à envoltória de Mohr-Coulomb e de Hoek-Brown. No ponto 5 , as tensões ultrapassam à envoltória de Mohr-Coulomb, mas não a de Hoek-Brown. Este histórico de tensões é explicado devido à redistribuição de tensões decorrentes da escavação. Nota-se, na FIGURA 5.5, que quando $\sigma_{1}$ atinge um valor máximo (tensão induzida), esse estado de tensões corresponde ao momento em que a profundidade de escavação se encontra na mesma profundidade onde se localiza o ponto de 
monitoramento e que geometricamente corresponde à zona do pé do talude para aquela etapa de escavação.

A partir dos fatos explicados nas FIGURAS 5.3, 5.4 e 5.5, pode-se deduzir que a trajetória de tensões modifica ou altera a resistência do maciço rochoso. A modificação da resistência estaria associada à criação de novas fraturas, as quais reduzem a resistência do maciço rochoso, provocando desta forma o fenômeno de amolecimento. Assim, quanto maior o número de fraturas criadas, mais a resistência coesiva é afetada.

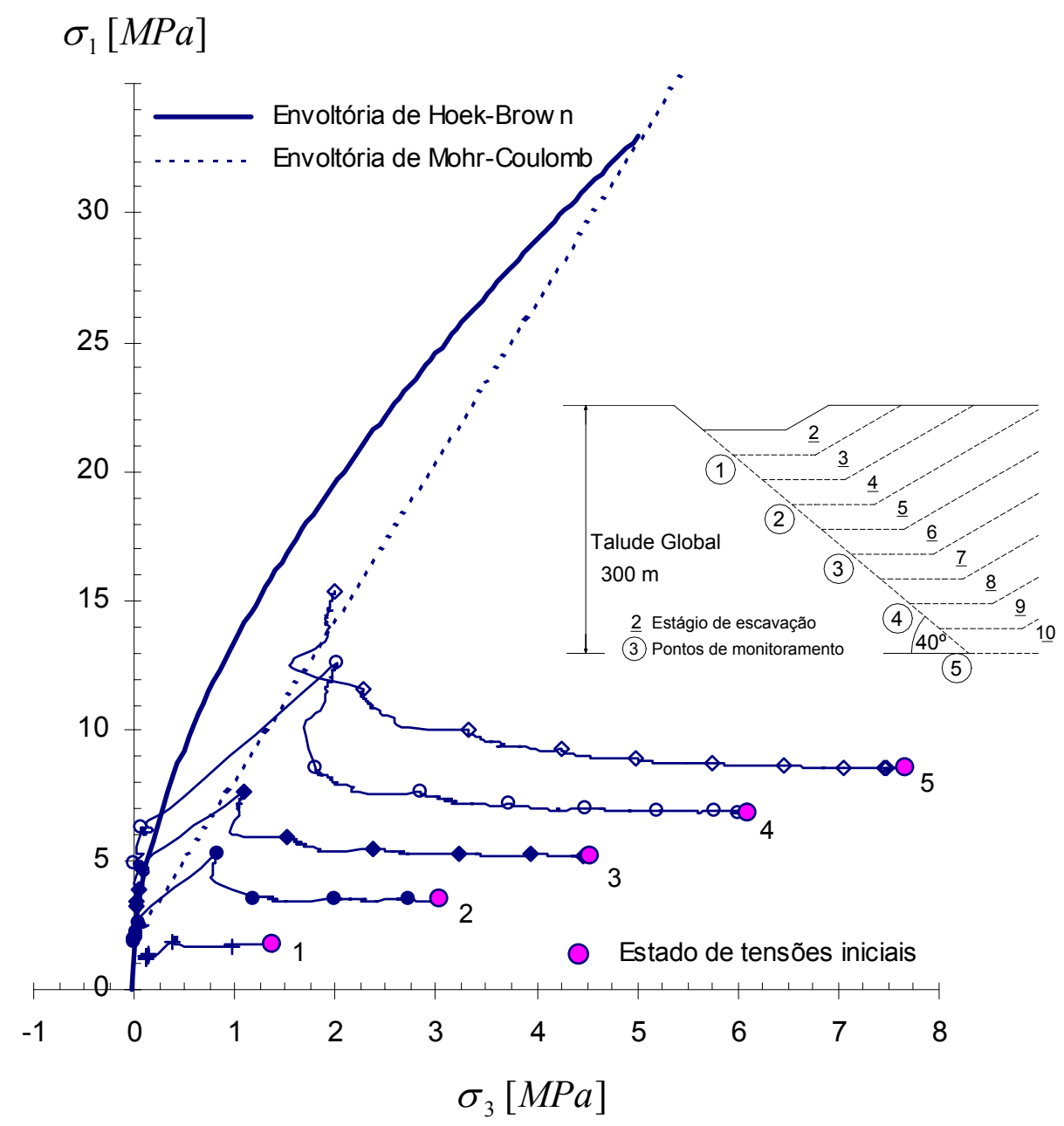

FIGURA 5.5 Trajetória das tensões decorrentes do avanço da escavação para pontos localizados no pé do talude nos diferentes estágios de escavação, num talude de 300 metros de altura e ângulo de talude de $40^{\circ}$ e $k=1,1$.

Conforme os estudos de MARTIN et al. (1995) no laboratório de pesquisa subterrânea (URL) no Canadá, a resistência in situ do maciço reduz-se pela metade se comparada à resistência estimada no laboratório. Essa perda de resistência ocorre devido 
ao dano (novas fraturas) induzido pela trajetória de tensões atuantes diante da frente de escavação.

A rotação das tensões apresentadas na FIGURA 5.4 tem um papel importantíssimo, isto devido ao fato de que a orientação das tensões principais associadas àquele momento de acúmulo de tensões no maciço rochoso define as orientações de crescimento das micro-fissuras e fraturas, podendo, assim, definir a anisotropia induzida por dano.

\subsubsection{Tensões Elásticas ao Longo da Superfície de Ruptura}

Na FIGURA 5.6, mostram-se as trajetórias das tensões principais $\left(\sigma_{1}-\sigma_{3}\right)$ para pontos localizados ao longo de uma provável superfície de ruptura.

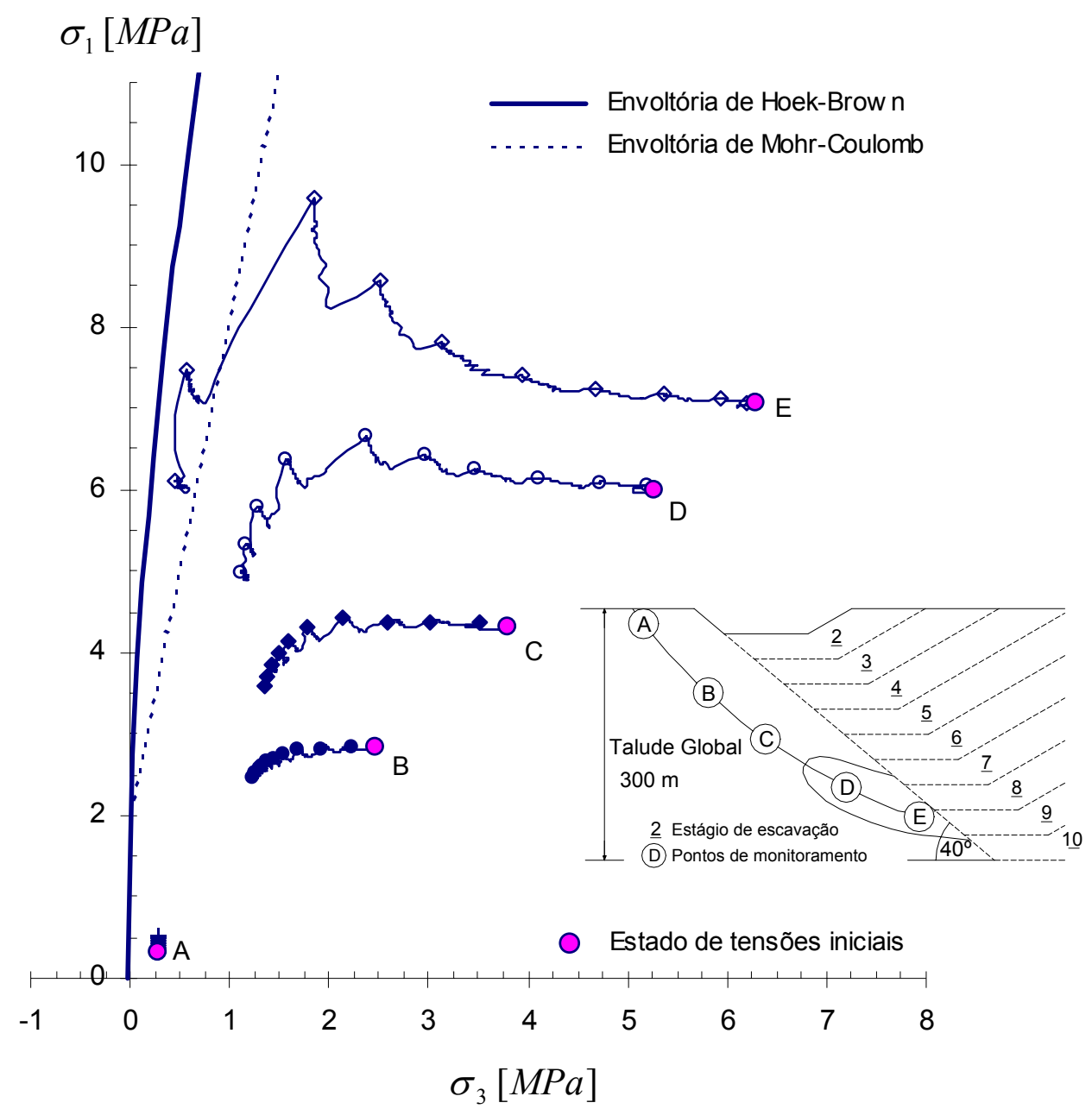

FIGURA 5.6 Trajetória das tensões decorrentes do avanço da escavação para pontos localizados ao longo de uma provável superfície de ruptura nos diferentes estágios de escavação, num talude de 300 metros de altura e ângulo de talude de $40^{\circ}$ e $k=1,1$. 
Na FIGURA 5.6, nota-se que, para os pontos A, B e C, a magnitude de $\sigma_{1}$ é pouco afetada pela escavação. A magnitude de $\sigma_{1}$ no ponto $\mathrm{D}$ atinge $\mathrm{o}$ seu valor máximo correspondente a 6,6 $\mathrm{MPa}$ no estágio 6 , porém, nos estágios 7 a 10 , ela diminui gradativamente a $4.97 \mathrm{MPa}$. A magnitude de $\sigma_{1}$ no ponto $\mathrm{E}$ comportou-se de modo igual àqueles pontos localizados no pé do talude, por estar ele localizado numa posição similar. Neste ponto, $\sigma_{1}$ atinge seu valor máximo de $9,57 \mathrm{MPa}$ no estágio 8 , diminuindo rapidamente no estágio 9 para $7,46 \mathrm{MPa}$, e, no estágio 10, para 6,12 $\mathrm{MPa}$. A tensão de confinamento para o ponto $A$ foi constante e igual a $0,31 \mathrm{MPa}$. Os pontos $\mathrm{B}, \mathrm{C}, \mathrm{D}$ e $\mathrm{E}$ sofrem perda gradativa da tensão de confinamento. $\sigma_{3}$ atinge uma magnitude em torno de 1,2 MPa para o estágio 10 nos pontos $B, C$ e $D$, enquanto que no ponto $E$, há uma maior perda do confinamento, atingindo a magnitude de 0,46 MPa.

Conforme a FIGURA 5.6, só dois pontos (D e E) sofrem variações relativamente significativas de $\sigma_{1}$ e $\sigma_{3}$. Com base nas trajetórias das tensões elásticas da FIGURA 5.6, observa-se que a trajetória de tensões para os pontos $B, C, D$ e $E$ nos primeiros 6 estágios de escavação correspondem à perda do confinamento. A tensão $\sigma_{1}$ nos pontos $\mathrm{B}$ e $\mathrm{C}$ diminui de 2,8 MPa para 2,6 MPa no ponto B e de 4,31 MPa para 4,3 MPa no ponto C. Já nos pontos $\mathrm{D}$ e $E$, sofre um acréscimo de 5,9 MPa para 6,6 MPa no ponto $D$ e de 7,04 MPa para 7,8 MPa no ponto E.

Da passagem do estágio 8 para 09 , o ponto $E$ atinge a envoltória de resistência adotada de Mohr-Coulomb para a rocha diorito, significando assim, teoricamente, uma condição de ruptura (dano). Nota-se na trajetória de tensões do ponto $E$ que, apesar do acréscimo de $\sigma_{1}$ no estágio 8, ela não atinge a condição de ruptura, o que só acontece depois de haver uma perda tanto de $\sigma_{1}$, como de $\sigma_{3}$ no estágio 9 , ou seja, o dano depende da combinação ou relação das tensões $\sigma_{1}$ e $\sigma_{3}$. No estágio 9 da escavação, as tensões elásticas do ponto $E$ ultrapassam a envoltória de resistência, indicando uma iminente condição de ruptura (danificação do maciço).

Da mesma forma que nos pontos localizados no pé do talude, a orientação da tensão principal maior no ponto $E$ (estágio 8 ) é de $22^{\circ}$ em relação à horizontal. É nesta mesma direção onde se pode ter o crescimento ou desenvolvimento de novas fraturas.

Por outro lado, conforme resultado das análises, cabe concordar com a afirmação de DODD e ANDERSON (1971), STACEY (1970) e SJÖBERG (1999) sobre a concentração de tensões no pé do talude e que este fenômeno provocaria ruptura. De acordo com a FIGURA 5.6, verifica-se que a trajetória de tensões para os pontos localizados próximo da região do pé do talude atinge a condição de ruptura, no entanto, 
nos pontos mais afastados, tais como o $B, C$ e o $D$, não atingem a ruptura. Este fato leva também a concordar com BISHOP (1967) e SJÖBERG (1999), os quais afirmam que a superfície de ruptura avança progressivamente da região do pé do talude para a sua crista. Uma observação a fazer é que a base da ruptura não necessariamente passa pelo pé do talude, conforme se apresenta na FIGURA 5.6. De fato, o início da ruptura na região do pé é amplamente explicado pela perda da resistência ou a danificação do maciço rochoso nestas regiões, tal danificação do maciço sendo decorrente das tensões induzidas.

\subsubsection{Influência do coeficiente de empuxo, $k$}

Com a finalidade de se conhecer a influência do coeficiente de empuxo nas tensões induzidas, foram feitas análises com o mesmo procedimento seguido nas análises de trajetória de tensões, mas desta vez foi variado o coeficiente de empuxo. Nas análises, foram adotados valores de coeficiente de empuxo iguais a 1,1; 1,3; 1,5 e 1,7.

Na FIGURA 5.7, apresenta-se o gráfico da tensão principal maior induzida versus o coeficiente de empuxo. Neste gráfico, foram plotadas a tensão principal maior induzida (decorrente da escavação) pertencente aos pontos localizados na região do pé do talude conforme foi mostrado na FIGURA 5.3, para taludes que variam de 60 até 600 metros de altura.

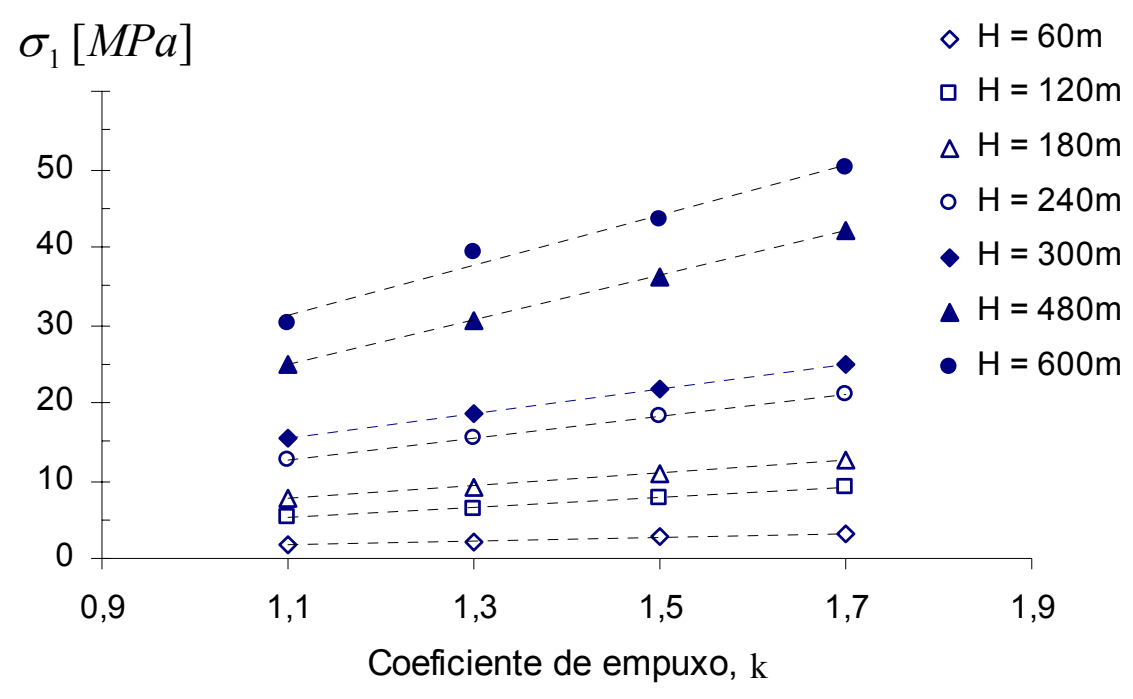

FIGURA 5.7 Tensão principal maior induzida versus o coeficiente de empuxo para pontos localizados na região do pé do talude, ângulo de talude $40^{\circ}$.

Conforme a FIGURA 5.7, claramente se verifica que a tensão principal maior, $\sigma_{1}$, tem um acréscimo linear em função do coeficiente de empuxo. O acréscimo de $\sigma_{1}$ é pouco significativo em profundidades rasas. Para maiores profundidades, o acréscimo de 
$\sigma_{1}$ se torna mais significativo. Por exemplo, a partir da FIGURA 5.7, para uma profundidade de 60 metros, $\sigma_{1}$ varia de $1,8 \mathrm{MPa}(k=1,1)$ para 3,05 $\mathrm{MPa}(k=1,7)$, e já para uma profundidade de 600 metros, $\sigma_{1}$ varia de $30,34 \mathrm{MPa}(k=1,1)$ para $50,17 \mathrm{MPa}$ $(k=1,7)$, percebendo-se, portanto, que o acréscimo de $\sigma_{1}$ é maior quanto maior é a profundidade.

Na FIGURA 5.8, apresenta-se o gráfico da tensão principal menor induzida versus o coeficiente de empuxo. Neste gráfico fica evidente que a tensão de confinamento também sofre um acréscimo linear em função do coeficiente de empuxo. Apesar de que o confinamento monitorado, para todos os casos, corresponde ao ponto localizado na região do pé do talude, esta também varia em função da altura do talude, sendo maior o confinamento quanto maior for a altura do talude.

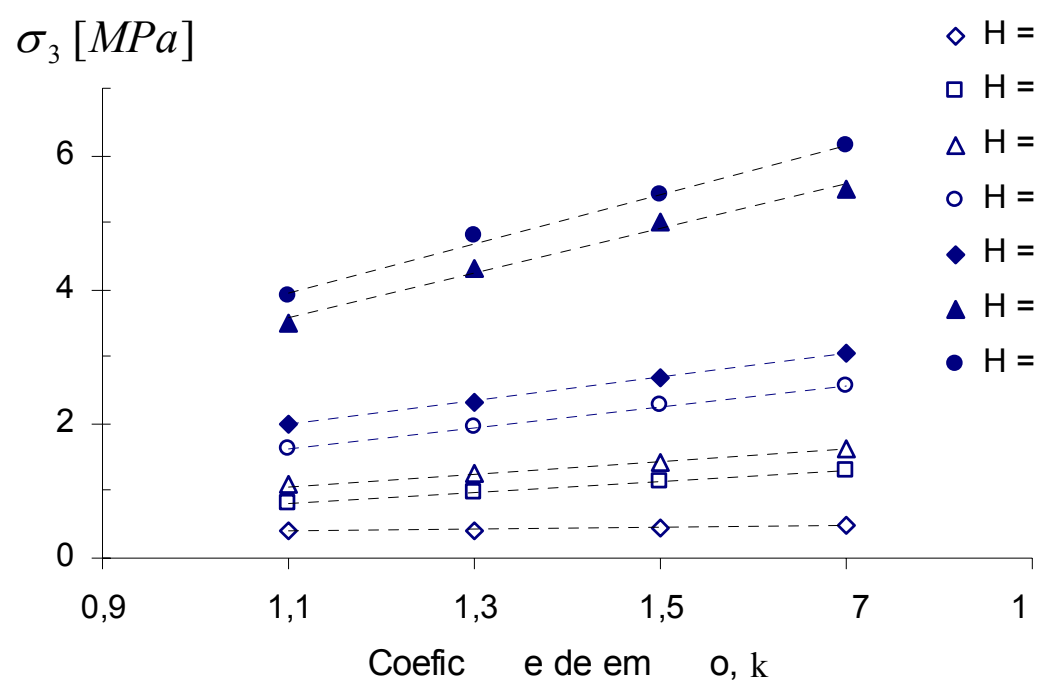

FIGURA 5.8 Tensão principal menor induzida versus o coeficiente de empuxo para pontos localizados na região do pé do talude, ângulo de talude $40^{\circ}$.

$\mathrm{Na}$ FIGURA 5.9, apresenta-se o estado de tensões induzido correspondentes à região do pé do talude, desta vez representado no espaço $\sigma_{1} \times \sigma_{3}$. Os estados de tensões plotados nesta figura correspondem a diferentes coeficientes de empuxo.

Conforme a FIGURA 5.9, o estado de tensões elásticas, em forma independente do coeficiente de empuxo, para alturas de taludes superiores a 180 metros superam a envoltória adotada de Mohr-Coulomb e encontra-se na condição de ruptura. Esta afirmação aplica-se somente para este caso exemplificado. 


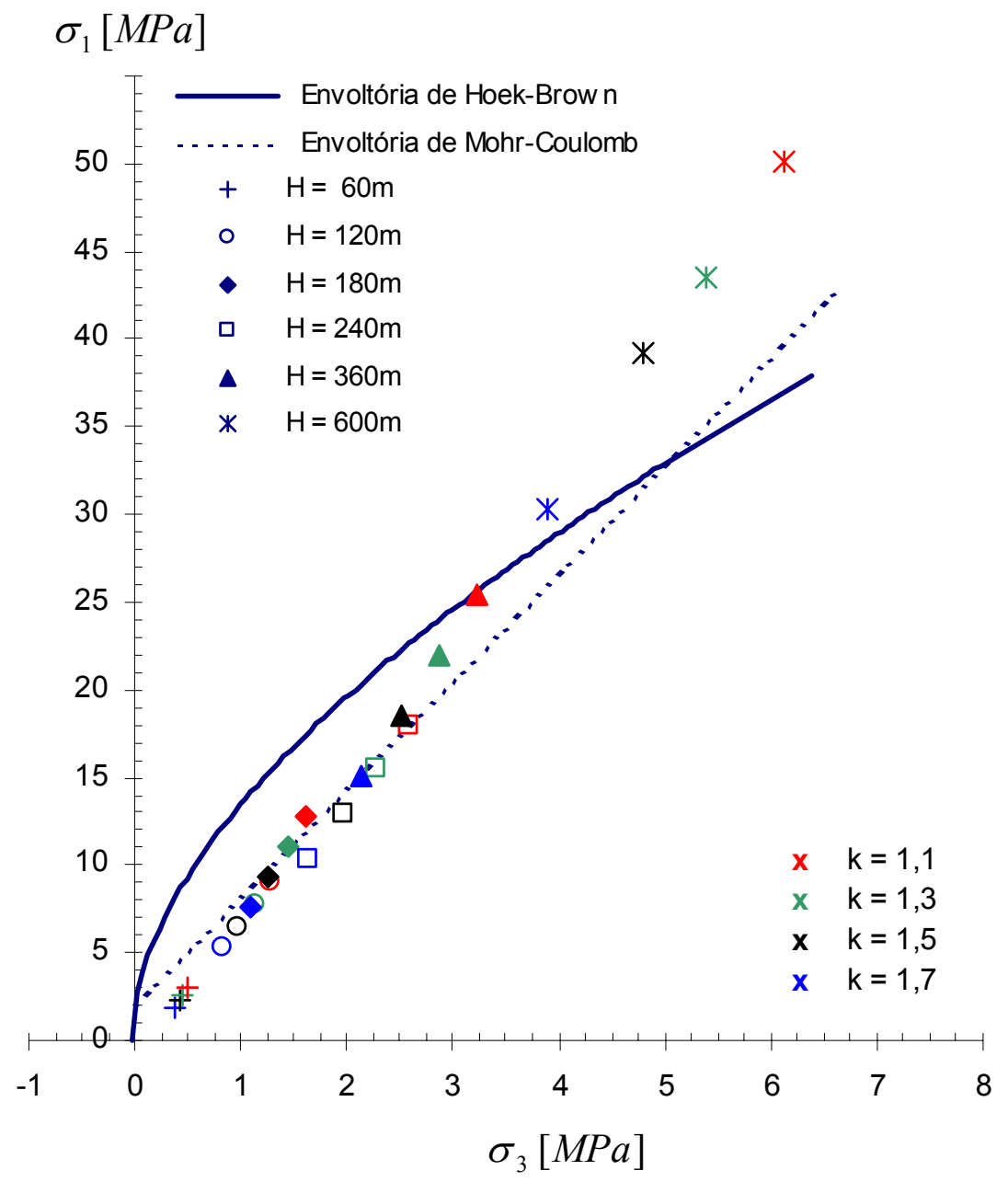

FIGURA 5.9 Estado de tensões induzido na região do pé do talude, para diferentes alturas de taludes e coeficientes de empuxo, ângulo de talude $40^{\circ}$.

Na FIGURA 5.9, nota-se que para cada altura de talude se encontram plotados quatro estados de tensões diferentes, dos quais pertencem para quatro valores diferentes de coeficiente de empuxo. A tensão principal maior em magnitude guarda uma relação direta com o coeficiente de empuxo; assim, o estado de tensão que tem menor magnitude de $\sigma_{1}$ corresponde ao menor coeficiente de empuxo adotado $(k=1,1)$ e vice-versa.

Em relação ao coeficiente de empuxo, salienta-se que, quanto maior é o $k$, maior é a magnitude das tensões induzidas, podendo implicar qualitativamente uma maior região de danificação no pé do talude.

Na FIGURA 5.10, apresenta-se a orientação da tensão principal maior induzida versus o coeficiente de empuxo. Fica evidenciado claramente que a orientação de $\sigma_{1}$ varia em função do coeficiente de empuxo. De forma independente da altura do talude, o 
ângulo de orientação do $\sigma_{1}$ diminui com o acréscimo do $k$. Esta diminuição do ângulo de orientação do $\sigma_{1}$ está na média de $2^{\circ}$, conforme evidenciado na FIGURA 5.10.

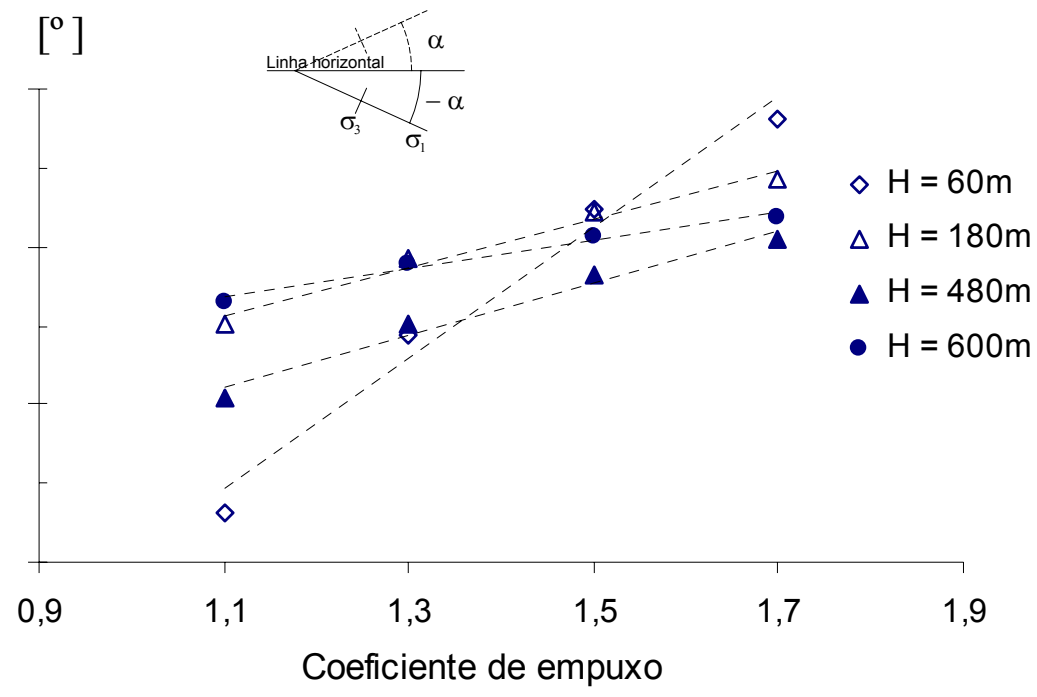

FIGURA 5.10 Orientação da tensão principal maior induzida versus o coeficiente de empuxo, para a região do pé do talude.

Na FIGURA 5.11, mostra-se adicionalmente a orientação da tensão principal maior induzida versus a altura do talude, para diferentes valores do coeficiente de empuxo. Com base nesta figura, pode-se dizer que a orientação da tensão principal maior varia de $-19^{\circ}$ a $-22^{\circ}$. Sendo que o ângulo de $-22^{\circ}$ está relacionado ao coeficiente de empuxo $k=1,1$ e o ângulo de $-19^{\circ}$ ao $k=1,7$.

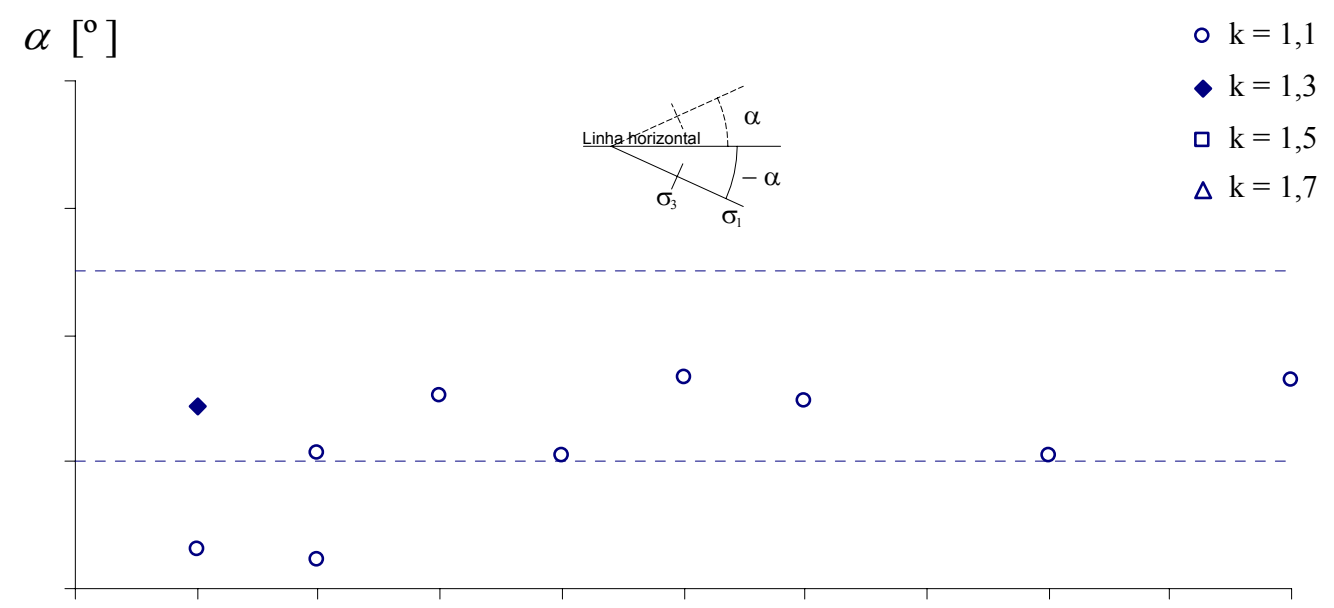

FIGURA 5.11 Orientação da tensão principal maior induzida para a região do pé do talude versus a altura do talude. 


\subsection{Fraturamento Previsto - Discussão}

Conforme as análises apresentadas previamente, ficou evidenciado que há concentração de tensões em regiões do pé do talude e que estas tensões induzidas, decorrentes das mudanças da geometria (avanço de escavação), podem gerar fraturamento induzido. Assim, pode-se afirmar que a trajetória de tensões modifica ou altera a resistência do maciço rochoso. A manifestação física desta alteração estaria relacionada ao surgimento de novas fraturas, que diminuem a resistência do maciço, provocando, assim, o fenômeno de amolecimento.

Na FIGURA 5.12, mostra-se um esquema teórico-idealizado do desenvolvimento de fraturas paralelas a $\sigma_{1}$ decorrentes das tensões induzidas (avanço da escavação) na região do pé do talude, para um ponto localizado a 240 metros de profundidade. O esquema baseia-se num talude de 300 metros de altura, ângulo de talude de $40^{\circ}$ e um coeficiente de empuxo de $k=1,1$. Neste gráfico, o estado de tensões A, B e C corresponde ao ponto monitorado 4, para profundidades de 0,240 e 300 metros, respectivamente.

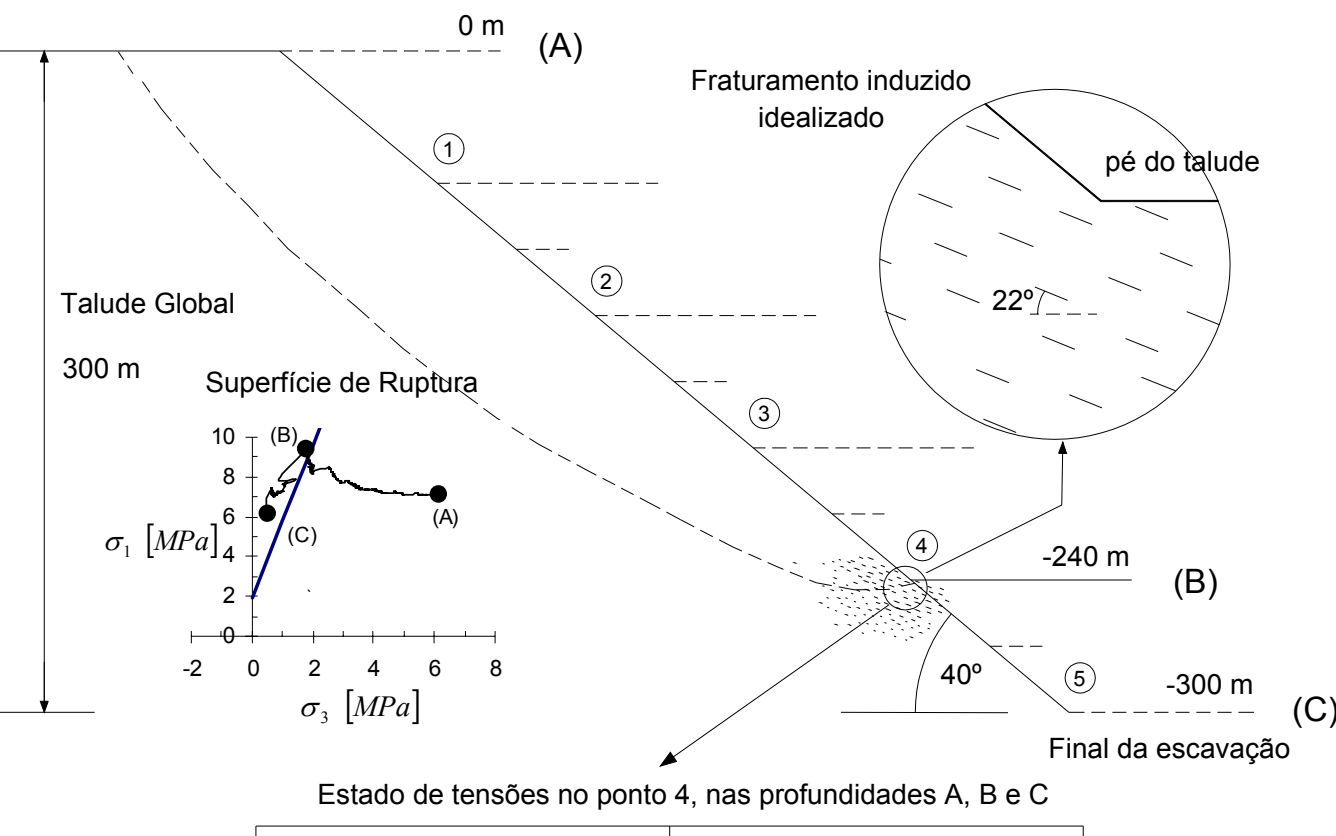

(A)

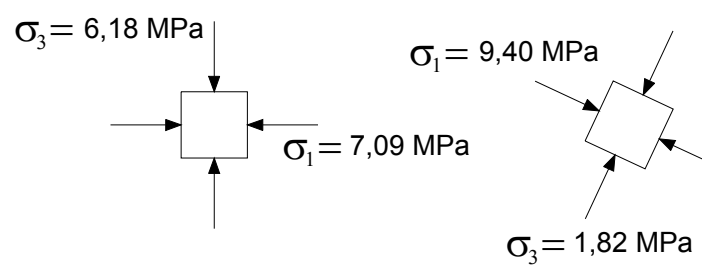

(B)

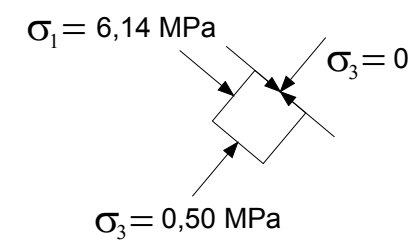

FIGURA 5.12 Esquema teórico-idealizado do desenvolvimento de fraturas em regiões de acúmulo de tensões (pé do talude) decorrentes do avanço da escavação. 
Se as tensões induzidas superam a resistência do maciço, o crescimento das novas fraturas deve ter uma orientação em função da distribuição ou orientação das tensões principais. Com a concentração de tensões no pé do talude decorrentes da escavação, conforme relatado neste trabalho, além disso, conforme discutido nas FIGURAS 5.10 e 5.11, e considerando os estudos de HOLZHAUSEN e JOHNSON (1979), as novas fraturas criadas pelas tensões induzidas teriam uma orientação que varia de $19^{\circ}$ a $22^{\circ}$ (FIGURA 5.12) em relação à horizontal para a região do pé do talude, gerando desta forma uma anisotropia.

Para o caso de estudo de taludes considerando as novas fraturas decorrentes das tensões induzidas, verifica-se que a sua persistência dependerá da tensão de confinamento. Além disto, sabe-se que nas proximidades da face do talude o confinamento tende a zero. Pode-se dizer, então, que o crescimento das novas fraturas será mais significativo quanto mais próximas elas se encontrarem da face do talude. Salienta-se que estas conclusões baseadas nas comparações dos estudos em laboratório e nas obtidas na modelagem são qualitativas, contudo o raciocínio é coerente.

Por outro lado, as novas fraturas podem interagir com as descontinuidades préexistentes, deteriorando, desta forma, o maciço por mecanismos de coalescência, que em conjunto poderiam gerar mecanismos de ruptura do tipo progressivo.

\subsection{Análise com o Modelo de Amolecimento da coesão e de Endurecimento do atrito por deformação plástica}

Conforme as análises elásticas discutidas anteriormente, o acúmulo de tensões na região do pé do talude, decorrentes das mudanças da geometria, gera dano ao maciço rochoso. Com a finalidade de quantificar o dano conseqüente das tensões induzidas, daqui por diante a simulação será feita com um modelo elasto-plástico considerando Amolecimento da coesão e de Endurecimento do atrito. Para isto será utilizado o programa $\mathrm{FLAC}^{2 \mathrm{D}}$ versão 3.3 , na qual foram implementadas as funções que levem em consideração a perda da resistência coesiva e a mobilização e degradação do atrito como sub-rotinas no modelo original de Mohr-Coulomb. Tais funções devem ser ajustadas a dados de laboratório, conforme apresentado no Capítulo 4.

Os parâmetros de entrada adotados para a rocha Diorito a serem usados na simulação numérica com o modelo de Amolecimento da coesão e de Endurecimento do atrito são mostrados na FIGURA 5.13. 

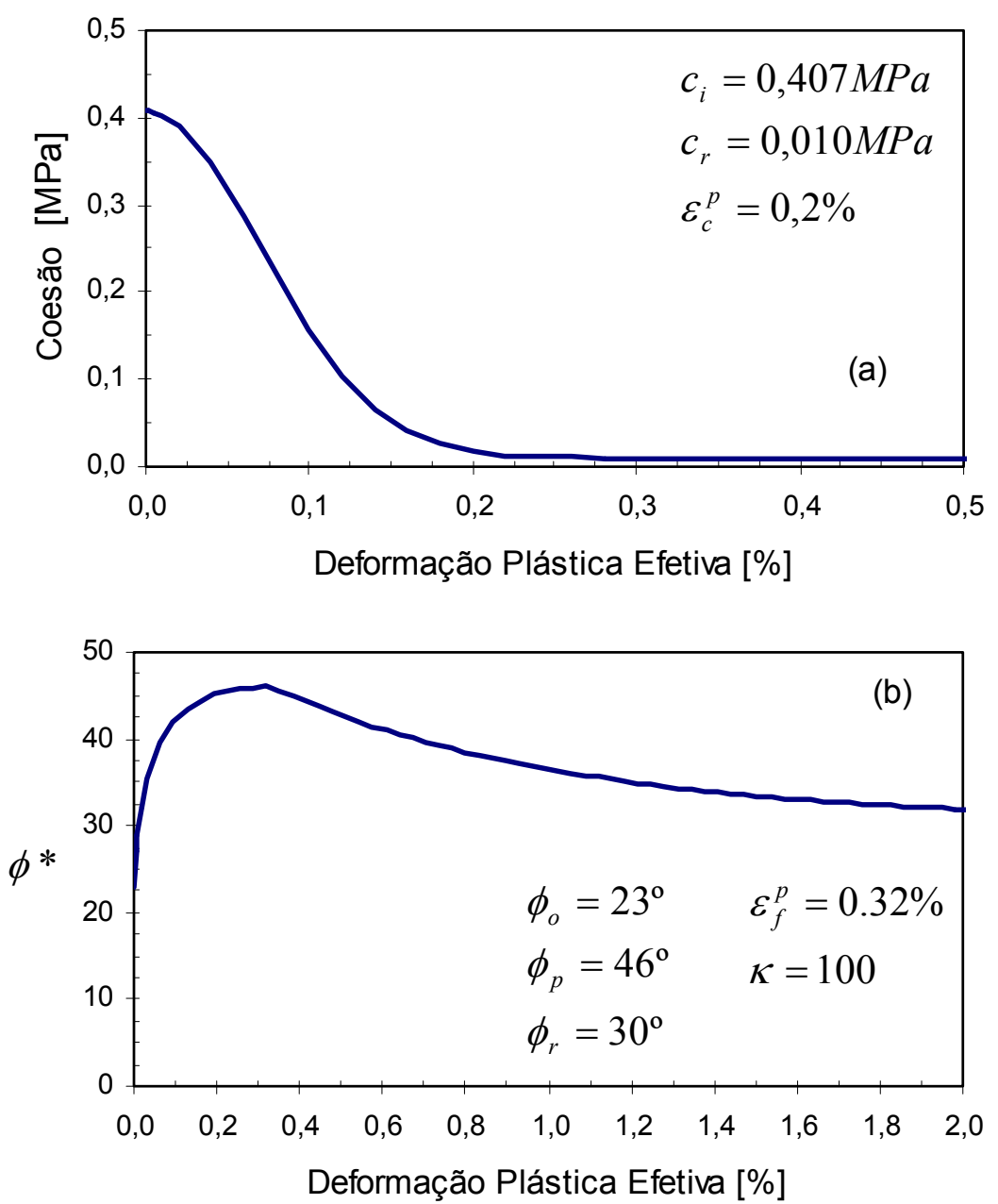

FIGURA 5.13 (a) Amolecimento da coesão, (b) comportamento de mobilização e de degradação do atrito total adotados para a rocha Diorito.

Para a rocha Diorito, foram adotados os mesmos limites de deformações plásticas $\left(\begin{array}{lll}\varepsilon_{c}^{p} & \text { e } & \varepsilon_{f}^{p}\end{array}\right)$ do granito Lac du Bonnet. Quanto aos parâmetros $\varepsilon_{c}^{p}$ e $\varepsilon_{f}^{p}$ adotados para a rocha Diorito, os valores podem ser outros ainda desconhecidos. Embora os parâmetros possam ser diferentes, serão usados os valores aí apresentados com a finalidade de mostrar o dano induzido devido à trajetória de tensões decorrente do avanço da escavação.

Por outro lado, conforme as características geomecânicas da rocha Diorito (TABELA 1), ela se encontra fraturada, de modo que, conforme discutido no Capítulo 4 , pode-se dizer que devido ao fraturamento prévio do maciço rochoso, o atrito já foi mobilizado numa certa porcentagem. Estimativas de atrito mobilizado inicial e atrito de pico para o maciço rochoso, do ponto de vista do autor deste trabalho, precisam de mais 
estudos. No presente trabalho, foi considerado o atrito mobilizado inicial, $\phi_{o}$, igual ao $50 \%$ do atrito de pico.

Conforme a literatura, na maioria das rochas, as juntas experimentam ruptura associada a certos valores de atrito, que variam de $25^{\circ}$ a $35^{\circ}$ (BANDIS, 1993). No presente trabalho, o atrito residual, $\phi_{r}$, foi adotado como sendo de $30^{\circ}$. A constante adimensional $\kappa$, que simula a forma da curva pós-pico, foi adotada como sendo igual a 100.

Da mesma forma que as análises elásticas, foi simulado o avanço da escavação em estágios de 30 metros por vez, reproduzindo, assim, uma escavação em bancadas com altura de 30 metros.

Na FIGURA 5.14, apresenta-se a distribuição da resistência coesiva num talude de 300 metros de altura. Claramente aparece a conseqüência do dano do maciço rochoso decorrente da concentração de tensões na região do pé do talude. Conforme discutido no Capítulo 4, salienta-se que o amolecimento da coesão é conseqüência direta do dano do maciço rochoso. Na FIGURA 5.15, apresenta-se a mobilização do ângulo de atrito como conseqüência do dano por deformação do maciço rochoso para o mesmo talude.

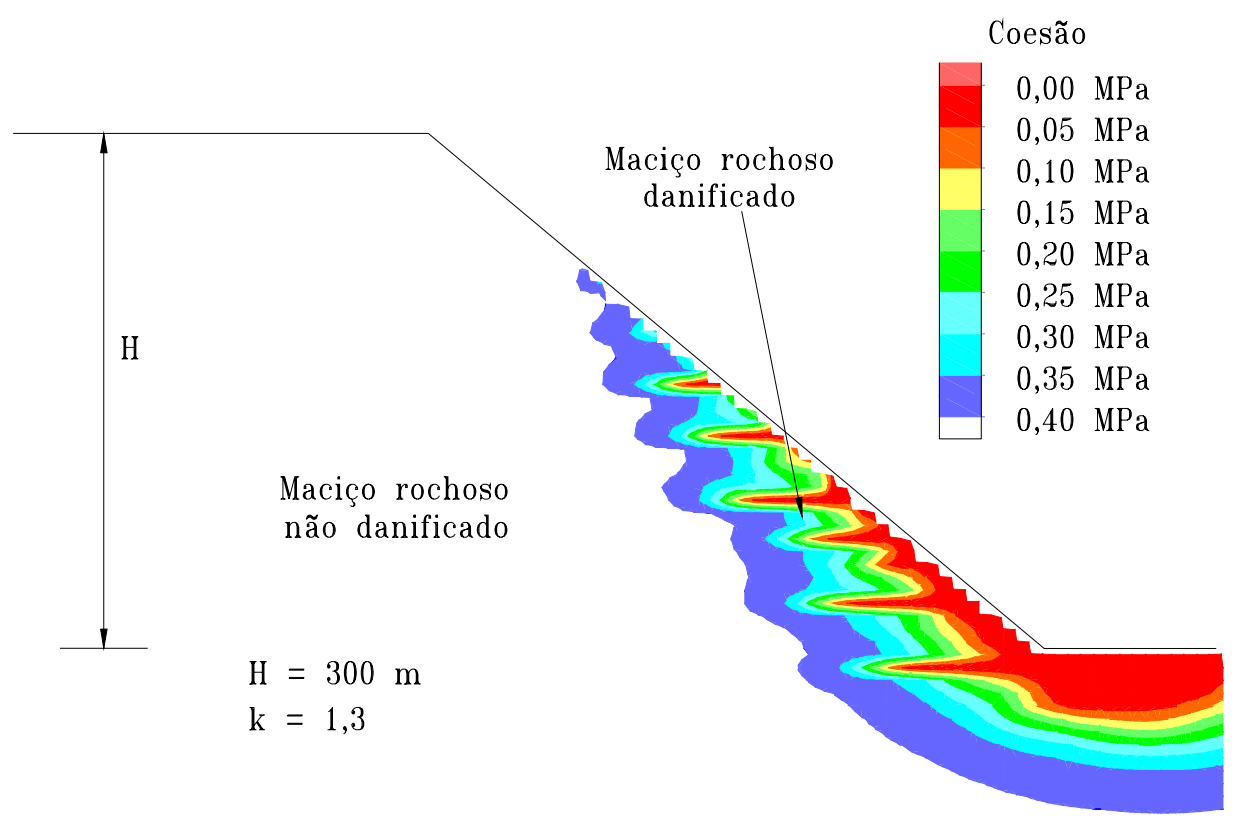

FIGURA 5.14 Perda da resistência coesiva em decorrência do dano devido ao avanço da escavação num talude de 300 metros de altura. 


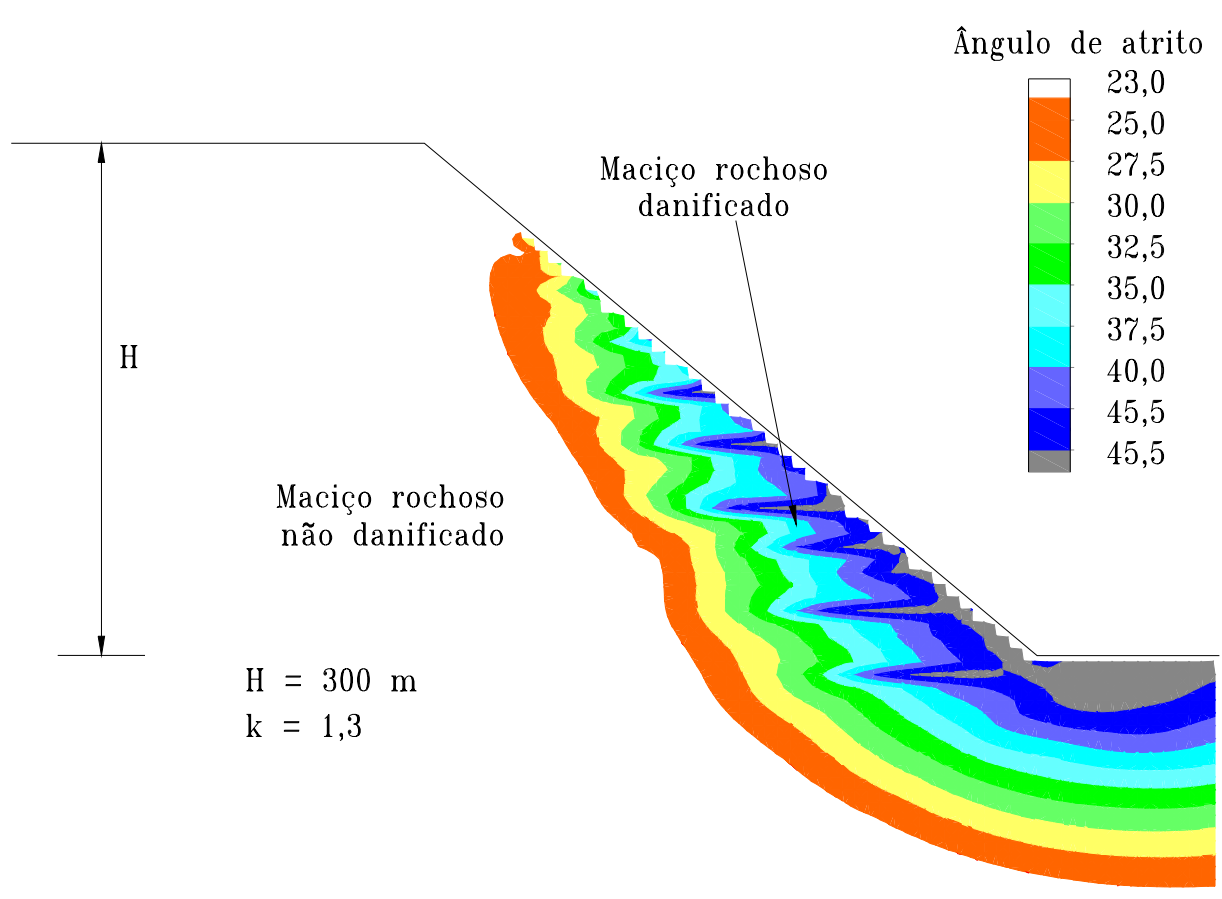

FIGURA 5.15 Mobilização do atrito em decorrência do dano devido ao avanço da escavação num talude de 300 metros de altura.

Conforme as FIGURAS 5.14 e 5.15, claramente se observa uma heterogeneidade em relação à resistência coesiva e ao atrito. Esta heterogeneidade induzida com direções preferenciais é decorrente do avanço progressivo da escavação (tensões induzidas). Nas representações tanto da coesão quanto do atrito, nota-se, claramente concentrações de danos nas cotas correspondentes às bases das bancadas; estas estão associadas a baixos valores de coesão (FIGURA 5.14) e a altos valores de atrito (FIGURA 5.15). A baixa coesão e os altos valores de atrito são devidos ao maior grau de dano do maciço rochoso em conseqüência do acúmulo de tensões no pé do talude e vizinhanças.

O dano do maciço rochoso não foi somente concentrado na região do pé do talude, mas também nas vizinhanças, afetando o maciço de forma gradativa de fora para dentro, tanto na direção horizontal, quanto na vertical. Regiões próximas da face do talude são as que se encontram mais danificadas e áreas mais afastadas se encontram menos danificadas até chegar a uma rocha isenta de dano.

Cabe salientar que o dano do maciço rochoso representado nas FIGURAS $5.14 \mathrm{e}$ 5.15 é apenas devido às tensões induzidas decorrentes do avanço da escavação. Existem outras fontes que podem originar dano ao maciço, por exemplo, vibrações causadas pelo desmonte por explosivos, amplamente usados em mineração a céu aberto. 
A simulação de etapas de escavação com 30 metros de altura representa uma aproximação. Bancadas reais variam de 15 a 30 metros de altura, e a remoção da rocha fragmentada após o desmonte por explosivos é gradual. A concentração de tensões no pé do talude, responsável pelo dano ao maciço, é resultante também da remoção da rocha fragmentada e o correspondente alívio de tensões, fenômeno que pode afetar toda a extensão da face do talude quando a simulação da remoção da rocha for realizada em camadas horizontais com alturas pequenas. Pode ser que as zonas de dano observadas (maior dano no pé) no maciço apenas nas cotas correspondentes às bases das bancadas de remoção sejam mais extensas que as mostradas nesta análise.

O fato acima pode representar um fator contra a segurança. $O$ dano e a plastificação correspondentes ao nível do pé da bancada provocam redistribuição de tensões para cima e para baixo, no domínio da rocha que, pela simulação numérica, não foi tão danificada quanto pode ser na realidade. Portanto, o novo equilíbrio é conseguido mais rapidamente na simulação numérica, já que ela permite que parte do maciço não tão danificado em decorrência da aproximação contribua para a convergência com uma nova configuração de zona danificada menos extensa que a real.

O grau de danificação do maciço rochoso é altamente dependente das tensões induzidas, da resistência coesiva inicial, da estimativa do atrito mobilizado inicial e de pico e dos limites de deformações plásticas, $\varepsilon_{c}^{p}$ e $\varepsilon_{f}^{p}$. Cabe salientar que uma boa estimativa destes limites de deformações plásticas, a partir de ensaios cíclicos levaria a resultados mais realistas ou mais aproximados ao caso real. Os mesmos parâmetros de entrada tanto de coesão, como de atrito com valores diferentes de $\varepsilon_{c}^{p}$ e $\varepsilon_{f}^{p}$ conduzem a resultados completamente diferentes, podendo representar diferentes configurações de dano do maciço.

A partir das discussões anteriores e tendo-se por base as FIGURAS 5.14 e 5.15, pode-se dizer que, quanto maior é altura dos estágios de escavação, menor é o dano que se induz ao talude, e quanto menor for a altura dos estágios de escavação, maior é o dano induzido ao talude.

\subsubsection{Influência do coeficiente de empuxo, $k$}

Com a finalidade de se conhecer a influência do coeficiente de empuxo no dano induzido ao talude, foram feitas análises variando-se aquele valor. Nas análises, foram adotados valores de coeficiente de empuxo iguais a 1,1; 1,3; 1,5 e 1,7 . 
Na FIGURA 5.16, apresenta-se a distribuição da perda da resistência coesiva (dano) como conseqüência das tensões induzidas, indicando os parâmetros geométricos adotados a serem apresentados graficamente.

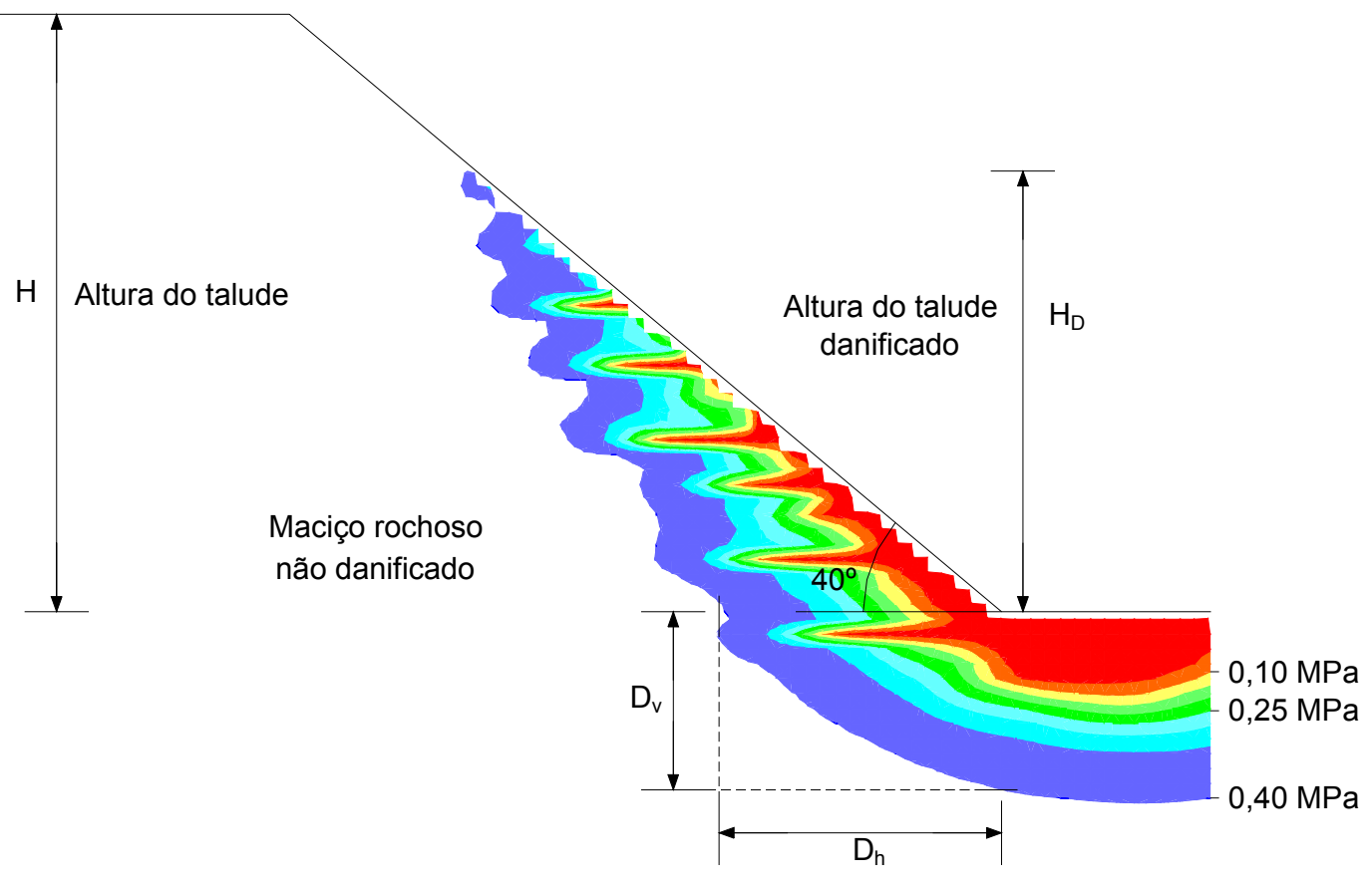

FIGURA 5.16 Plotagem da perda da resistência coesiva (dano) e os respectivos parâmetros geométricos adotados para definir o dano no talude.

Conforme a FIGURA 5.16, foi definido alguns parâmetros geométricos para definir o dano no talude: $H$ como a altura do talude, $H_{D}$ como a altura do talude danificado, $D_{V}$ como extensão do dano na direção vertical abaixo da cota correspondente à base da bancada; e $D_{H}$ como extensão do dano na direção horizontal.

Na FIGURA 5.17, apresenta-se a variação dos parâmetros $H_{D}, D_{H}$ e $D_{V}$ em função da altura do talude para diferentes coeficientes de empuxo. 
a)

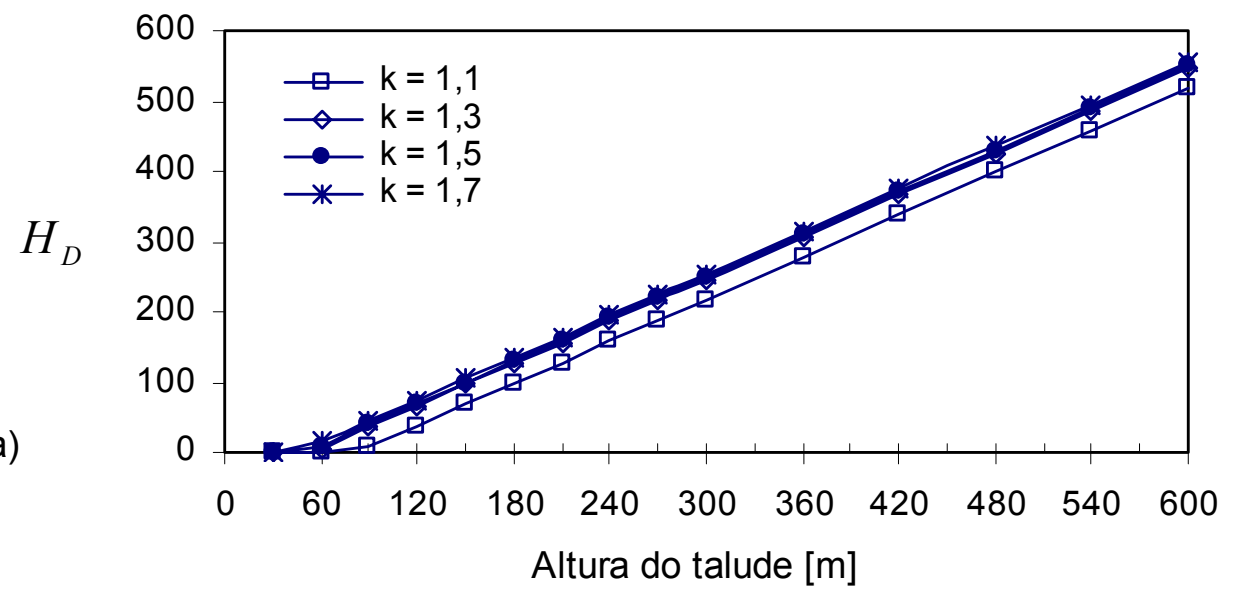

b)

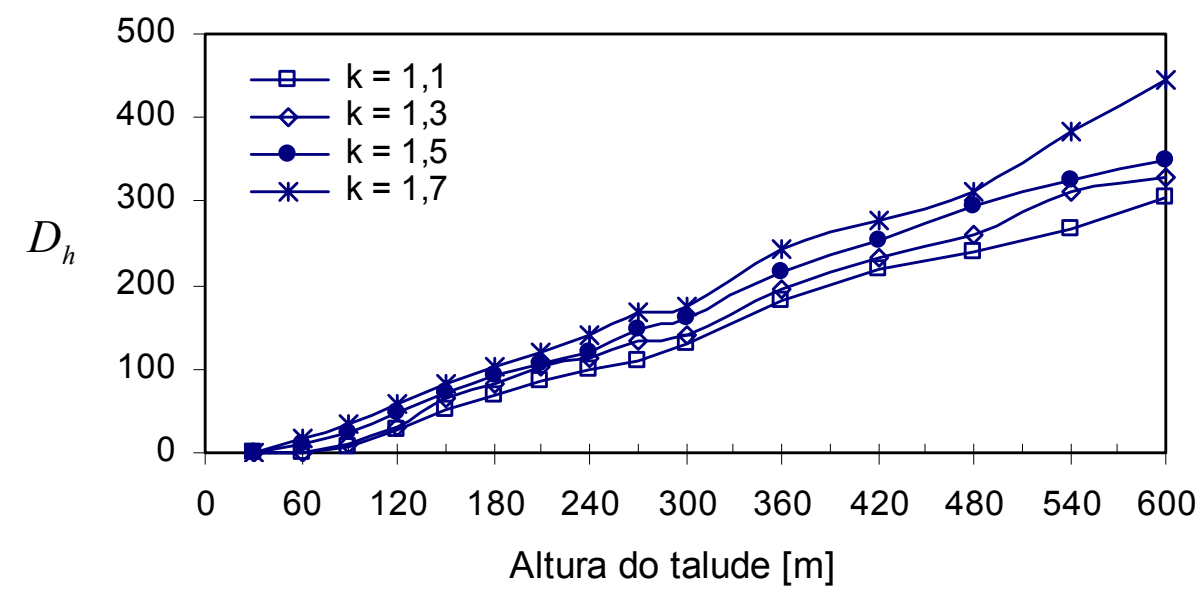

c)

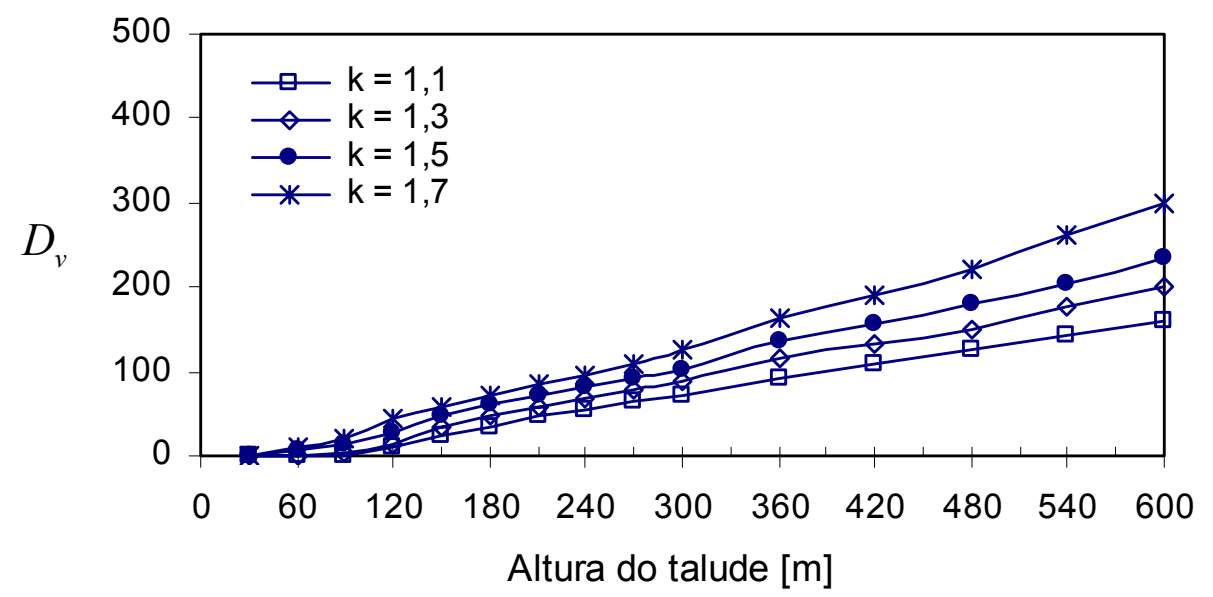

FIGURA 5.17 Variação do parâmetro $H_{D}, D_{H}$ e $D_{V}$ em função da altura do talude.

Nota-se que a altura do talude danificado, $H_{D}$, mostra um crescimento linear em relação à altura do talude (FIGURA 5.17a). Isto acontece para os diferentes valores adotados do coeficiente de empuxo. Salienta-se que $H_{D}$ é pouco sensível às mudanças do coeficiente de empuxo. Conforme mostrado na FIGURA 5.17a, as curvas para 
diferentes coeficientes de empuxo se mostram quase superpostas. Na FIGURA 5.17b se mostra a extensão do dano horizontal $D_{H}$, que sofre um acréscimo linear em função do acréscimo da altura do talude. Conforme a FIGURA 5.17b, $D_{H}$ varia em função do coeficiente de empuxo, correspondendo maior comprimento de $D_{H}$ a um maior coeficiente de empuxo. A altura da zona danificada, $D_{V}$, também cresce linearmente com a altura do talude. $D_{V}$ varia também em função do coeficiente de empuxo, sendo maior este comprimento quanto maior for o coeficiente de empuxo.

Na FIGURA 5.18, apresentam-se os mesmos resultados da FIGURA 5.17, mas, desta vez os parâmetros adotados de $H_{D}, D_{H}$ e $D_{V}$ são apresentados de forma adimensionalizada $H_{D} / H, D_{H} / H$ e $D_{V} / H$ respectivamente. Salienta-se que a altura do talude, $H$, não é um valor fixo, variando incrementalmente conforme o avanço da escavação.

Conforme a FIGURA 5.18a, pode-se dizer que a extensão vertical da zona danificada, $H_{D}$, tem um crescimento relativo mais rápido que a altura do talude. Conforme esta figura, para um coeficiente de empuxo igual a 1,1 taludes até uma altura de 90 metros se mostram sem danificação a pouca danificação. Já para coeficientes de empuxo superiores a 1,3, a danificação, embora pequena começa em taludes de 30 metros. Estas mesmas afirmações podem ser observadas nas FIGURAS $5.18 \mathrm{~b}$ e c.

Na FIGURA 5.18b, mostra-se a variação da relação $D_{H} / H$ com a altura do talude. A variação mostra-se basicamente em forma crescente. Salienta-se que $D_{H} / H$ tem crescimento rápido até alturas de talude da ordem de 150 metros, depois o crescimento é mais suave, indicando crescimento da extensão horizontal do dano praticamente linear com a altura do talude.

Na FIGURA 5.18c, mostra-se a variação de $D_{V} / H$ com a altura do talude. $D_{V} / H$ cresce rapidamente, mas de modo distinto para diferentes alturas de talude. 

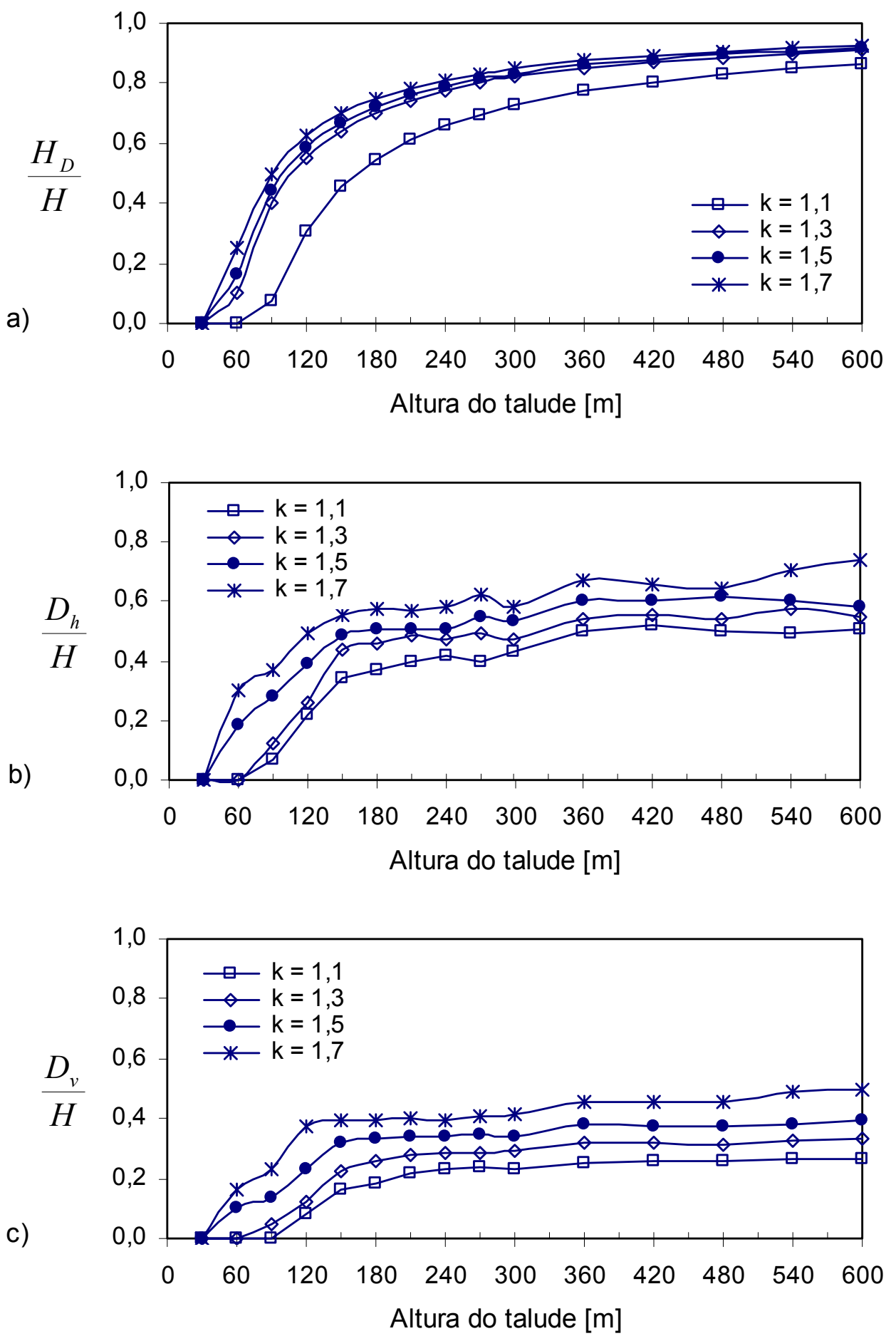

FIGURA 5.18 Variação do parâmetro $H_{D} / H, D_{H} / H$ e $D_{V} / H$ em função da altura do talude.

Cabe salientar que as afirmações feitas a partir da FIGURA 5.18 são válidas para o caso exemplificado de parâmetros da rocha Diorito, e podem ser diferentes para outros tipos de rocha. 


\subsection{Avaliação do Fator de segurança}

A avaliação da segurança a partir de análises numéricas de tensões é um tema que merece desenvolvimentos que não serão concluídos nesta fase da pesquisa. Nas últimas décadas, a técnica de redução de resistência (ZIENKIEWICZ et al., 1975) tem sido a mais empregada, como demonstram trabalhos recentes (PARK et al., 2004; CARDOSO et al., 2004). Porém ela apresenta sérias restrições para aplicação em casos em que a ruptura envolva rocha intacta. Segundo aquela técnica, a avaliação da segurança é feita em análises considerando comportamento plástico, em que os parâmetros de resistência (coesão e ângulo de atrito, no caso do critério de Mohr-Coulomb) são ambos reduzidos progressivamente pelo mesmo fator, até que se caracterize o colapso por meio de grandes deslocamentos. De acordo com evidências experimentais amplamente discutidas no Capítulo 3, não existe a simultâneidade de disponibilidade de resistências coesiva e de atrito com valores de pico, o que cria sérias dificuldades conceituais para a técnica de redução de resistências. O caráter evolutivo da configuração do talude de uma mina a céu aberto é outro fator complicador da avaliação de sua segurança. Uma análise mais abrangente deverá tomar todos estes fatores em consideração, e não faz parte dos objetivos desta fase da pesquisa.

Para avaliar a importância do dano na quantificação da segurança, em relação à prática corrente, apresenta-se a seguir uma análise simplificada em um talude hipotético de $300 \mathrm{~m}$ de altura, com inclinação de $40^{\circ}$, constituído do mesmo diorito cujas propriedades foram analisadas no Capítulo 4. Buscou-se levar em conta o caráter evolutivo do talude, com uma análise de tensões e deformações levando em conta as trajetórias de tensão e o dano ao material intacto até se atingir a configuração de escavação com $300 \mathrm{~m}$ de altura. A partir deste ponto, realizou-se uma análise por equilíbrio limite adotando os parâmetros de resistência remanescentes após o dano acumulado até aquele ponto. A análise por equilíbrio limite compara fatores de segurança calculados pelo procedimento clássico (análise 1, com coesão e ângulo de atrito de pico, portanto sem dano) e por um procedimento que leva em conta o dano progressivo decorrente da trajetória de tensões a que cada ponto do maciço foi submetido ao longo do histórico da escavação (análise 2).

Os fatores de segurança foram obtidos com o uso do programa NONCIR (CELESTINO e DUNCAN, 1980 e 1981) que busca a superfície não circular crítica.

Os parâmetros de resistência correspondentes ao maciço rochoso não danificado são $c=0,407 \mathrm{MPa}, \phi=46^{\circ}$. Se na análise numérica de tensões tivesse sido usado o 
modelo de Mohr-Coulomb, os parâmetros de coesão e de atrito teriam que ser mantidos constantes e iguais àqueles valores em todas as etapas de escavação. Na análise 1 pelo método convencional de equilíbrio limite, os parâmetros de entrada considerados foram aqueles valores. $\mathrm{Na}$ análise 2, considerando a danificação do maciço rochoso, os parâmetros de entrada são os que resultaram da análise evolutiva da escavação, considerando o modelo de dano, como já apresentado nas FIGURAS 5.14 e 5.15. Nesta análise, os valores de coesão, próximos à face do talude, são menores que o valor inicial devido ao dano; no caso do ângulo de atrito, são os correspondentes ao atrito mobilizado para cada zona.

Nas análises realizadas, foi estimado o fator de segurança para a superfície de ruptura inicial, tendo sido a mesma superfície adotada para ambas as análises. Foram também obtidos a superfície crítica e seu correspondente fator de segurança em cada caso. Os resultados são apresentados na TABELA 5.2 e nas FIGURAS 5.19 (análise 1, convencional) e 5.20 (análise 2, considerando o dano). $\mathrm{Na}$ análise 2, os perfis de resistência foram representados de modo simplificado em relação àqueles das Figuras 5.14 e 5.15 .

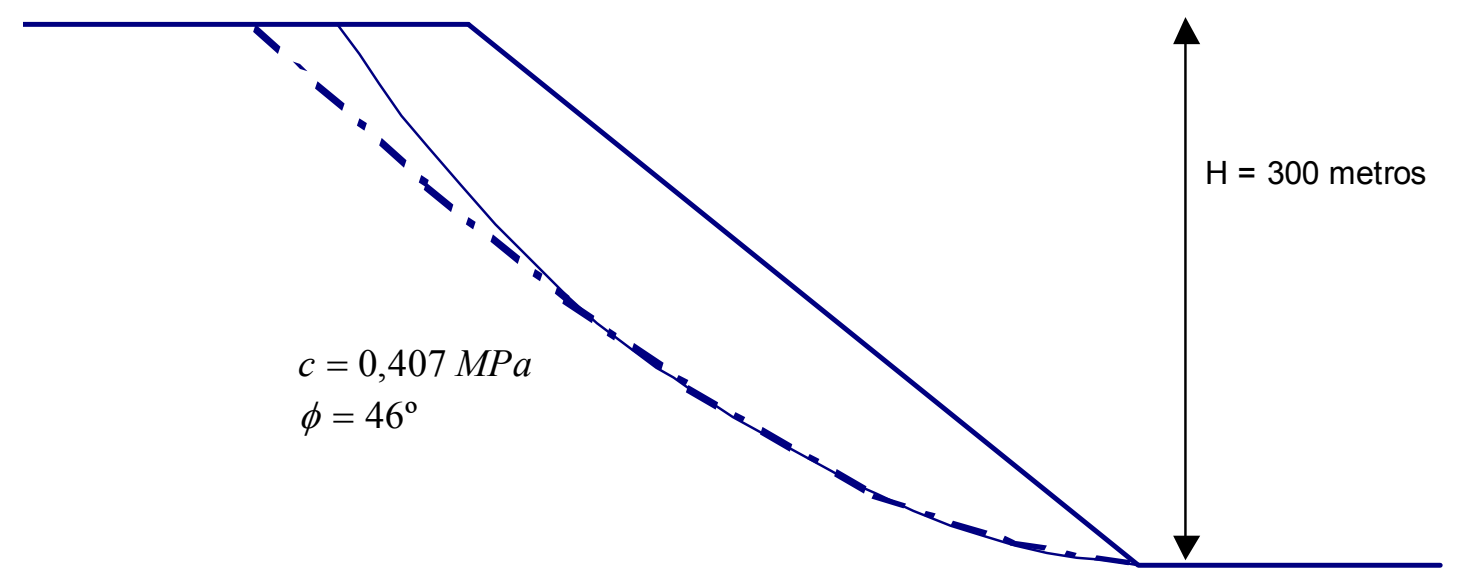

- - - Superfície de Ruptura Inicial Superficie de Ruptura Crítica 1

FIGURA 5.19 - Análise 1: procedimento convencional sem consideração do dano 


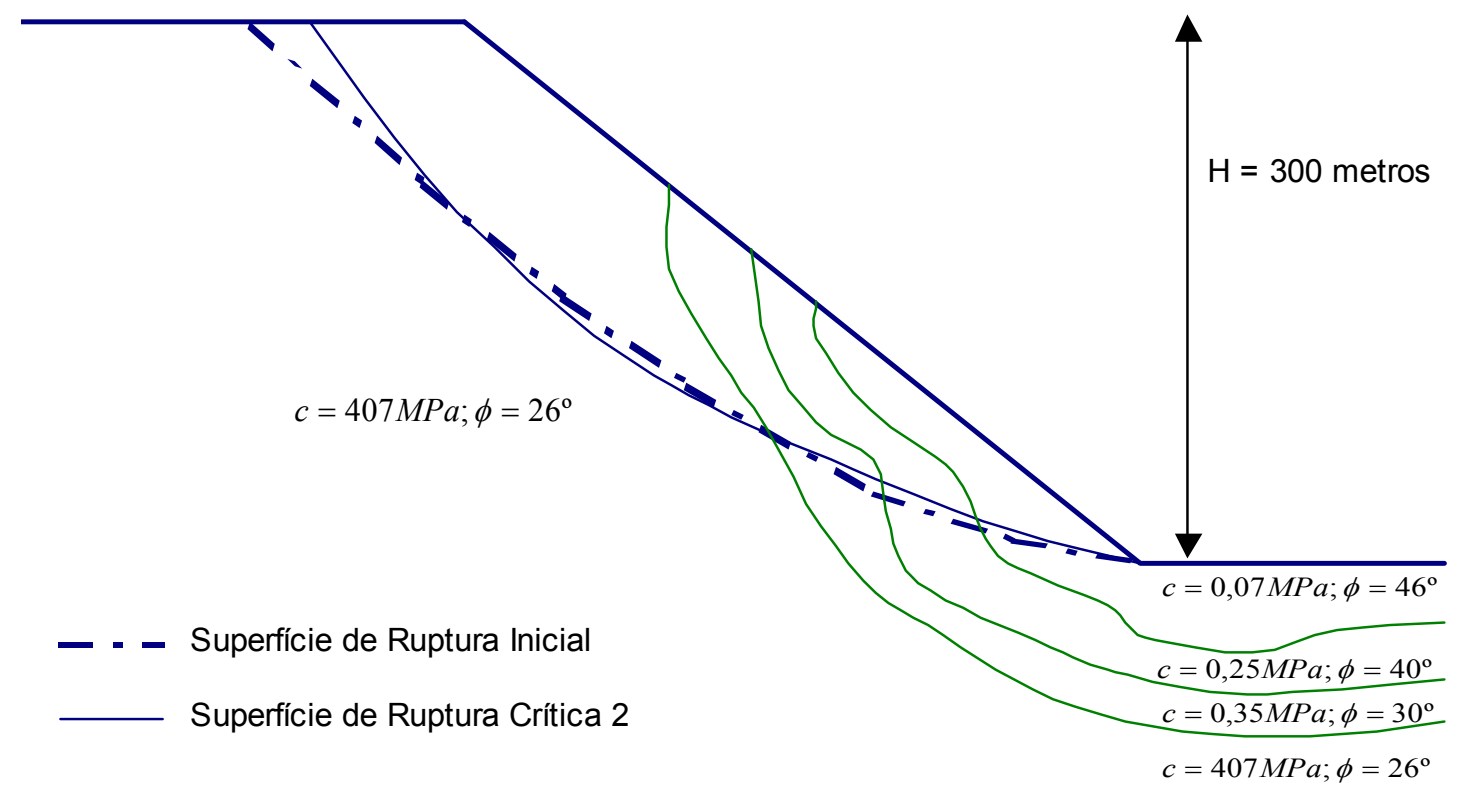

FIGURA 5.20 - Análise 2: procedimento com consideração de dano, modelo simplificado.

TABELA 5.2 Estimativa do fator de segurança por análise convencional e por análise com dano.

\begin{tabular}{lcc}
\hline & Análise convencional & Análise com dano \\
\hline Superfície ruptura inicial & 2,118 & 1,345 \\
Superfície ruptura crítica 1 & 2,067 & --- \\
Superfície ruptura crítica 2 & --- & 1,317 \\
\hline
\end{tabular}

Observa-se dos resultados que a consideração de dano pode conduzir a decréscimo significativo do fator de segurança. Embora obtidos de forma simplificada, estes resultados ilustram a importância da consideração do dano na avaliação da segurança, e que procedimentos de uso corrente em engenharia podem apresentar resultados falsamente seguros. Salienta-se que a diferença se torna significativa quando aumentam a altura do talude e o coeficiente de empuxo $k$. 


\subsection{Tipos de Instabilidade em taludes}

MARTIN et al. (2003), considerando o nível de tensões, observaram dois tipos de rupturas em escavações subterrâneas: rupturas com controle estrutural e rupturas por tensões induzidas. Segundo aqueles autores, as rupturas com controle estrutural apresentam-se em ambientes de baixo confinamento (como em profundidades rasas) ou condicionadas por fatores de geometria (queda de cunhas em condições de carga gravitacional tanto no teto como nas paredes do túnel), ao passo que as rupturas por tensões induzidas apresentam-se quando a magnitude destas tensões atinge a resistência do material intacto. O processo de ruptura é afetado e dominado eventualmente pelo dano causado ao maciço, o qual se traduz em crescimento de novas fissuras induzidas.

Conforme as classificações de HOEK et al. (2000b), HUDSON e HARRISON (1997) e MARTIN et al. (2003), considerando-se basicamente o dano devido às tensões induzidas, os tipos de ruptura para taludes de grande altura (alturas acima de 500 metros) poderiam ser separados em: (a) rupturas com controle estrutural, e (b) rupturas por dano induzido. Sabe-se que ambientes de baixo confinamento se apresentam em taludes de mineração a céu aberto (áreas próximas à face do talude). Assim, nestes ambientes, a distribuição espacial de descontinuidades pré-existentes controla o processo de ruptura, dando origem a rupturas de pequeno porte. Em taludes de grande altura, conforme discutido, tem-se uma forte influência das tensões induzidas, as quais geram danificação ao maciço o que se reflete na perda da coesão e degradação do atrito. A danificação do maciço rochoso será tanto maior quanto maior for a altura do talude.

CARVALHO et al. (2002) descreveram uma ruptura ou zona instável num talude de 600 metros de altura da Mina Toquepala, Perú, em que a instabilidade mostra indícios suficientes de ser devida às tensões induzidas na região do pé do talude. No caso desta mina, com o avanço da escavação, a região do pé do talude sofre amolecimento devido às tensões induzidas, desta forma, provocando deslocamentos nesta área. Quando estes deslocamentos na região do pé do talude se incrementam, começa gradativamente o movimento ou deformação do talude como um todo. 


\section{Capítulo 6}

\section{Conclusões}

O trabalho trata da influência do histórico de tensões na degradação da resistência de maciços rochosos durante o processo evolutivo de escavação de uma minha a céu aberto e sua possível influência na estabilidade. Tradicionalmente, as análises de estabilidade de taludes consideram apenas a configuração final do talude. $O$ processo evolutivo submete porções próximas à face do talude a concentrações importantes de tensões, que nos casos de taludes altos, podem ser responsáveis por danos capazes de condicionar a estabilidade.

Para este fim, buscou-se na literatura informação sobre o comportamento mecânico de corpos de prova de rocha submetidos a certas trajetórias de tensões em ensaios de laboratório. Com base naqueles estudos, foram analisados os mecanismos de ruptura em taludes altos de mineração a céu aberto, considerando-se o avanço progressivo da escavação. As análises adotaram um modelo elasto-plástico com perda progressiva de coesão e mobilização simultânea de atrito. A rotina para simulação deste comportamento foi aferida com resultados de ensaios disponíveis na literatura. A partir de tais estudos, conforme discutido nos capítulos anteriores, pode-se delinear as conclusões que se seguem.

A mobilização das duas componentes de resistência, coesão e atrito, não é simultânea. Conforme a danificação do corpo de prova por micro-fissuras, dá-se a perda da resistência coesiva e a mobilização do atrito. No caso do atrito, logo depois de atingir a sua máxima mobilização, inicia-se a degradação. 
O modelo elasto-plástico de amolecimento da coesão e de endurecimento do atrito, que considera a perda da resistência coesiva e a mobilização e degradação do atrito total, ambas em função das deformações plásticas efetivas (dano), está baseado na proposta de VERMERR e DE BORST (1984). Tal modelo fica explicado e sustentado por resultados de ensaios cíclicos de carga e descarga apresentados por MARTIN (1993) e MARTIN e CHANDLER (1994).

O modelo elasto-plástico de amolecimento da coesão e de endurecimento do atrito foi testado para estudar o comportamento mecânico do granito Lac du Bonnet, e conforme discutido no Capítulo 4, o modelo representou adequadamente o mecanismo de ruptura (processo de ruptura) que acontece num corpo de prova de rocha intacta durante as solicitações. Apesar de o modelo não ter representado o trecho correspondente ao fechamento das micro-fissuras pré-existentes, na maior parte das aplicações o modelo permite obter resultados bastante satisfatórios. Isto pode ser verificado através do exemplo numérico apresentado no trabalho.

Conforme discutido no Capítulo 5, a partir das análises elásticas realizadas, conclui-se que a trajetória de tensões ou o histórico de tensões decorrentes do processo de escavação modificam os parâmetros de resistência do maciço rochoso ao longo do talude. Esta alteração da resistência se traduz em danificação da rocha decorrente da aparição de novas fissuras no maciço rochoso, fato que provoca perda da coesão em função do grau de fraturamento em áreas próximas do pé do talude. Além disso, ocorre uma diminuição do módulo de elasticidade em função do fraturamento.

A manifestação física da danificação do maciço rochoso são novas fraturas criadas por tensões induzidas, paralelas à direção da tensão principal maior. Assim, estas novas fraturas, para áreas próximas ao pé do talude, teriam uma orientação entre $19^{\circ}$ e $22^{\circ} \mathrm{em}$ relação à face do talude. Estas orientações são validas para um ângulo de talude igual a $40^{\circ}$ e coeficiente de empuxo que varia de 1,1 a 1,7. A persistência destas fraturas é dependente da tensão de confinamento, sendo mais significativos os crescimentos destas novas fraturas quando a tensão de confinamento tende a zero. Estas novas fraturas podem interagir com as fraturas pré-existentes, desenvolvendo mecanismos de coalescência, provocando, desta forma, a deformação do maciço e a conseqüente ruptura. O fenômeno explicado anteriormente pode gerar rupturas do tipo progressivo.

Conforme as análises elásticas, com o acréscimo da altura dos taludes, o acréscimo da tensão principal maior é significativo, e em decorrência a danificação do maciço rochoso nas regiões do pé do talude pode ocorrer em áreas ainda maiores, o que 
leva a afirmar que, em taludes de grande altura, há probabilidades da existência de rupturas por dano induzido.

A afirmação anterior fica bem mais clara com os resultados do modelo elastoplástico de amolecimento da coesão e de endurecimento do atrito por deformação plástica. Conforme estas análises a extensão das regiões danificadas do maciço rochoso, com um coeficiente de empuxo de 1,1 pode ser estimada na direção horizontal pela grandeza $D_{H}$, (região do pé do talude) que varia de $0,35 \mathrm{H}$ para um talude de 150 metros a $0,51 \mathrm{H}$ para um talude de 600 metros. Para o caso do coeficiente de empuxo de 1,7 o dano na direção horizontal varia de $0,55 \mathrm{H}$ a $0,74 \mathrm{H}$ para taludes de 210 e 600 metros respectivamente. $\mathrm{A}$ extensão do dano na direção vertical, $D_{V}$, para taludes com alturas acima de 150 metros se mostra mais constante. Esta altura da zona danificada, $D_{V}$, é da ordem de $0,25 \mathrm{H}$; $0,31 \mathrm{H} ; 0,35 \mathrm{H} ;$ e $0,43 \mathrm{H}$ para coeficientes de empuxo de 1,$1 ; 1,3 ; 1,5 ;$ e 1,7 , respectivamente, para taludes com alturas acima de 150 metros.

Conforme as análises numéricas com o modelo elasto-plástico de amolecimento da coesão e de endurecimento do atrito por deformação plástica, o talude tende a ser mais danificado quanto menor for a altura da bancada.

Pelas análises da extensão da zona danificada, pode-se afirmar que a ruptura em taludes altos começa numa região próxima do pé do talude e que talvez não coincida necessariamente com ela, porque com o contínuo avanço da escavação, sucessivas superfícies de ruptura estariam se formando. Para a prática de engenharia, pode-se recomendar a instrumentação geotécnica nas regiões próximas do pé do talude. Prismas refletores seriam adequados para monitorar os deslocamentos desta região. 0 monitoramento geotécnico pode ajudar na identificação de embarrigamentos na face do talude. Tais ocorrências podem dar-se com mais freqüência em lugares onde o coeficiente de empuxo seja maior que 1.

Quanto à avaliação do fator de segurança, pelo método convencional de equilíbrio limite foi obtido fator de segurança de 2,12 para um talude hipotético. Pela abordagem que considera a danificação do maciço rochoso com uma aproximação grosseira, foi obtido o valor de 1,35. A técnica de redução de resistência amplamente empregada superestima o fator de segurança em comparação com o modelo que considera a danificação do maciço.

Os estudos iniciados neste trabalho com relação aos mecanismos de ruptura deverão ter continuidade futuramente. Um tema imediato é procurar estabelecer uma técnica que permita a avaliação do fator de segurança considerando a mobilização não simultânea das componentes de resistência. Assim também, há a necessidade de testar a 
eficiência do modelo elasto-plástico de amolecimento da coesão e de endurecimento do atrito por deformação plástica em aplicações reais seja em taludes ou em túneis. Por outro lado, estudos em relação aos limites de deformação plástica $\left(\begin{array}{lll}\varepsilon_{c}^{p} & \text { e } & \varepsilon_{f}^{p}\end{array}\right)$, tanto para a rocha intacta quanto para o maciço rochoso precisam ser pesquisados. Existem noções de que estes limites de deformação plástica podem variar com o tamanho de grão dos minerais, entre outros parâmetros. 